UNIVERSIDADE DE BRASÍLIA

FACULDADE DE TECNOLOGIA

DEPARTAMENTO DE ENGENHARIA CIVIL E AMBIENTAL

\title{
PROPOSTA DE MODELO DE CENTRO DE REAPROVEITAMENTO PARA VEÍCULOS LEVES EM FIM DE VIDA ÚTIL: ANÁLISE DO DISTRITO FEDERAL
}

\section{LUIZA LAVOCAT GALVÃO DE ALMEIDA COELHO}

ORIENTADORA: ADELAIDA PALLAVICINI FONSECA

PUBLICAÇÃO: T.DM-004/ 2017

BRASÍLIA/ DF: MARÇO/ 2017 


\section{UNIVERSIDADE DE BRASÍLIA \\ FACULDADE DE TECNOLOGIA \\ DEPARTAMENTO DE ENGENHARIA CIVIL}

\section{PROPOSTA DE MODELO DE CENTRO DE REAPROVEITAMENTO PARA VEÍCULOS LEVES EM FIM DE VIDA ÚTIL: ANÁLISE DO DISTRITO FEDERAL}

\section{LUIZA LAVOCAT GALVÃO DE ALMEIDA COELHO}

DISSERTAÇÃO DE MESTRADO SUBMETIDA AO DEPARTAMENTO DE ENGENHARIA CIVIL E AMBIENTAL DA FACULDADE DE TECNOLOGIA DA UNIVERSIDADE DE BRASÍLIA COMO PARTE DOS REQUISÍTOS NECESSÁRIOS PARA A OBTENÇÃo DO GRAU DE MESTRE EM TRANSPORTES.

APROVADA POR:

ADELAIDA PALlaVICINI FONSECA, Prof. ${ }^{a}$ D.Sc., Universidade de Brasília (PPGT) (ORIENTADOR)

SÉRGIO RONALDO GRANEMANN, Prof. Dr., Universidade de Brasília (PPGT) (EXAMINADOR INTERNO)

DIANNE MAGALHÃES VIANA, Prof. ${ }^{a}$ Dr. ${ }^{a}$, Universidade de Brasília (ENM) (EXAMINADOR EXTERNO)

BRASÍLIA/DF, 10 de MARÇO de 2017. 


\section{FICHA CATALOGRÁFICA}

COELHO, LUIZA LAVOCAT GALVÃO DE ALMEIDA

Proposta de Modelo de Centro de Reaproveitamento para Veículos Leves em Fim de Vida Útil: Análise do Distrito Federal [Distrito Federal] 2017.

xiv, 135p., 210 x 297 mm (ENC/FT/UnB, Mestre, Transportes, 2017).

Dissertação de Mestrado - Universidade de Brasília. Faculdade de Tecnologia.

Departamento de Engenharia Civil e Ambiental.
1.Logística reversa
2.Pós-consumo
3. Veículos leves
4.Veículos em fim de vida útil
5. Desmontagem
6. Reaproveitamento
I. ENC/FT/UnB
II. Título (série)

\section{REFERÊNCIA BIBLIOGRÁFICA}

COELHO, L. L. G. A. (2017). Proposta de Modelo de Centro de Reaproveitamento para Veículos Leves em Fim de Vida Útil: Análise do Distrito Federal T.DM-004/2017, Departamento de Engenharia Civil e Ambiental, Universidade de Brasília, Brasília, DF, $135 p$.

\section{CESSÃO DE DIREITOS}

AUTOR: Luiza Lavocat Galvão de Almeida Coelho

TÍTULO DA DISSERTAÇÃO: Proposta de Modelo de Centro de Reaproveitamento para Veículos Leves em Fim de Vida Útil: Análise do Distrito Federal

GRAU: Mestre ANO: 2017

É concedida à Universidade de Brasília permissão para reproduzir cópias desta dissertação de mestrado e para emprestar ou vender tais cópias somente para propósitos acadêmicos e científicos. $\mathrm{O}$ autor reserva outros direitos de publicação e nenhuma parte dessa dissertação de mestrado pode ser reproduzida sem autorização por escrito do autor.

Luiza Lavocat Galvão de Almeida Coelho

SQN 205 Bloco I apartamento 302 - Asa Norte

70.843-090 Brasília - DF - Brasil. 


\section{AGRADECIMENTOS}

Agradeço aos professores da Universidade de Brasília por compartilharem os seus conhecimentos com tanto empenho e cooperarem para a minha formação acadêmica.

À Professora Simone Monteiro, por colaborar de forma compreensiva, mesmo que indiretamente, para a finalização dessa pesquisa.

Aos Professores Sérgio Granemann e Dianne Viana por contribuírem a cada seminário e por fazerem parte da banca de avaliação da minha dissertação.

Agradeço, em especial, à minha orientadora Professora Adelaida Pallavicini, pela dedicação, paciência e atenção aos meus trabalhos.

Agredeço aos representantes do DETRAN-DF e do SINDIRVE que contribuíram para o desenvolvimento do diagnóstico do reaproveitamento de veículos no Distrito Federal.

Agradeço aos meus pais, Clarice e Cícero, pelo amplo incentivo e suporte que sempre me deram para aprofundamento constante do meu conhecimento.

E, por fim, agradeço ao meu marido, Guilherme, a quem me faltam palavras de agradecimento pelo apoio, pela torcida e pela participação. 


\section{RESUMO}

Os pioneiros na logística reversa de veículos leves em fim de vida útil foram os Estados Unidos, a União Europeia e o Japão. Em seguida, diversos outros países desenvolveram os seus próprios modelos de sucesso. No Brasil, a recente Lei 12.977/ 2014 foi a primeira a abordar, em âmbito nacional, os veículos leves em fim de vida útil e ainda está em processo de implementação nos estados, dos quais o de São Paulo é o que já possui resultados positivos. De toda forma, os modelos anteriores não são adequados às condições restritas do estágio inicial das empresas atuantes no Distrito Federal. Sendo assim, o objetivo dessa dissertação foi propor um modelo de centro de reaproveitamento de veículos em fim de vida útil para essa localidade, tendo em vista as boas práticas, as legislações aplicáveis e a realidade observada. Complementarmente ao modelo, foi ilustrada a estrutura do problema em um diagrama do laço causal para compressão das variáveis chaves e do possível controle de dados para tomada de decisão quantitativa em seus estágios posteriores. Dessa maneira, ambos - modelo e diagrama - podem orientar as empresas a se adaptarem para melhor realização das suas atividades e, consequentemente, auxiliar o órgão executivo de trânsito (DETRAN-DF) no registro, controle e fiscalização dessas empresas. Assim, eles fornecem uma contribuição para um processo de desenvolvimento, implementação e aprimoramento gradual do mercado de reaproveitamento de veículos.

Palavras chave: logística reversa, pós-consumo, veículos leves, veículos em fim de vida útil, desmontagem, reaproveitamento. 


\begin{abstract}
The pioneers in the reverse logistics of end-of-life light vehicles were the United States, the European Union, and Japan. Afterwards, several other countries have developed their own successful models. In Brazil, the recent Law $n^{\circ} 12.977 / 2014$ was the first one to approach, at the national level, end-of-life light vehicles and is still in the process of implementation in all states, with São Paulo already reporting positive results. In any case, the previous models are not suited to the strict conditions of the early stage companies operating in the Federal District. Therefore, the goal of this dissertation was proposing a reuse center model for end-of-life vehicles for this location considering good practices, the applicable legislation, and the observed reality. In addition to the model, the structure of the problem was illustrated in a causal loop diagram for compression of key variables, and possible survey and data control for quantitative decision making in its later stages. That way, they both - model and diagram - can guide companies to adapt in order to better perform their activities and, as a result, assist the transport executive agency (DETRANDF) in the registry, control, and inspection of these companies. Thus, they contribute to the process of development, implementation, and gradual improvement of the vehicles reuse market.
\end{abstract}

Key words: reverse logistics, post-consumer, light vehicles, end-of-life vehicles, disassembly, reuse. 


\section{SUMÁRIO}

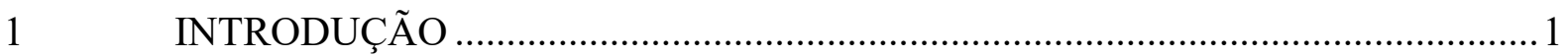

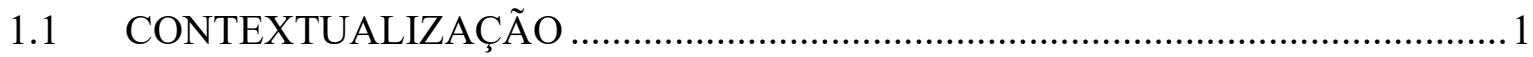

1.2 OBJETIVOS

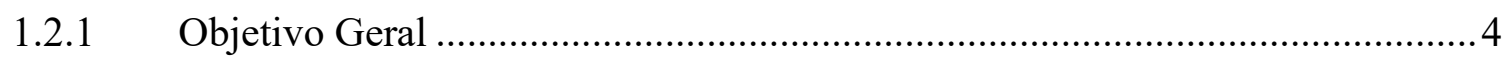

1.2.2 Objetivos Específicos ……………………….....................................

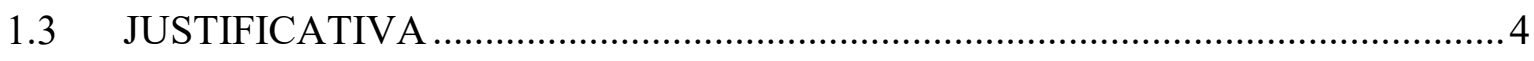

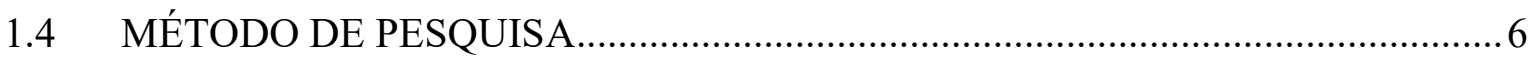

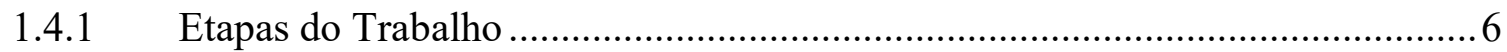

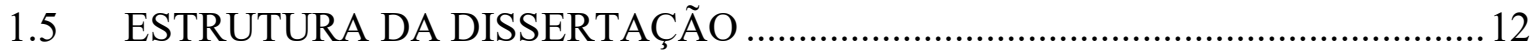

2 LOGÍSTICA REVERSA DE VEÍCULOS LEVES EM FIM DE VIDA

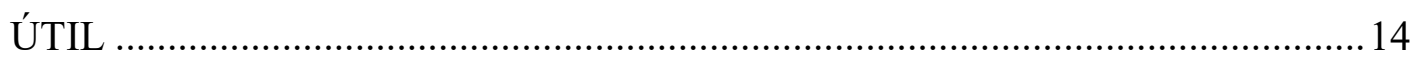

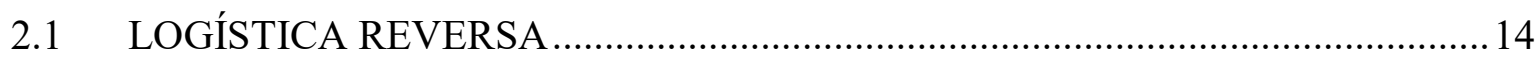

2.1.1 Logística Direta e Logística Reversa................................................................. 14

2.1.2 Logística Reversa e o Ciclo de Vida do Produto................................................ 17

2.1.3 Classificação da Logística Reversa ................................................................19

2.2 VEÍCULOS LEVES EM FIM DE VIDA ÚTIL ....................................................

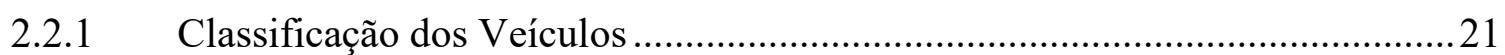

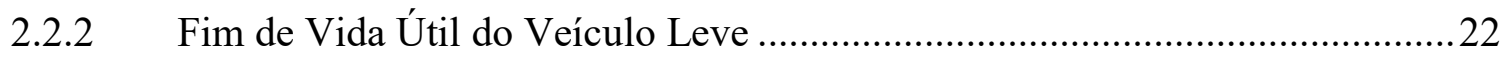

2.2.3 Impacto dos Veículos em Fim de Vida Útil ....................................................23

3 PANORAMA DO REAPROVEITAMENTO DE VEÍCULOS LEVES EM

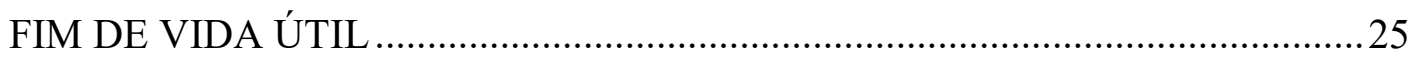

3.1 ASPECTOS LEGAIS DO REAPROVEITAMENTO DE VEÍCULOS ...................26

3.2 CADEIA DE REAPROVEITAMENTO DE VEÍCULOS LEVES ...........................29

3.3 ESTRATÉGIAS DE GERENCIAMENTO DE VEÍCULOS EM FIM DE

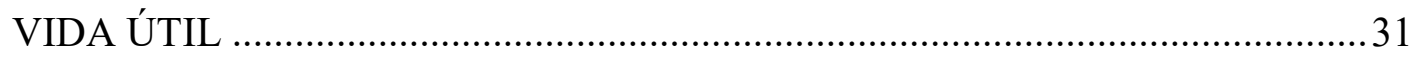

3.4 CENTROS DE REAPROVEITAMENTO DE VEÍCULOS LEVES ........................35

3.4.1 Estruturação das Atividades ...........................................................................35

3.4.2 Infraestrutura e Arranjo Físico …………………………………………..... 40

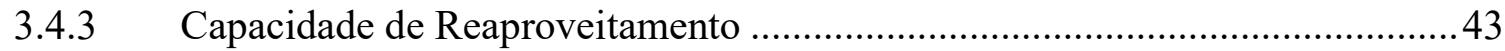

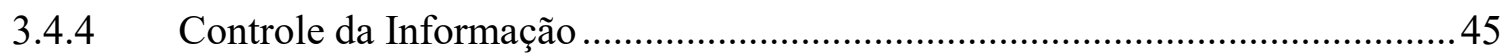

3.5 DIAGNÓSTICO DAS EMPRESAS DE REAPROVEITAMENTO ATUANTES NO DISTRITO FEDERAL 


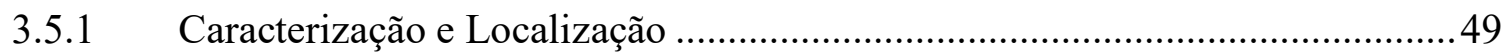

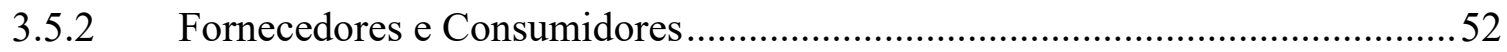

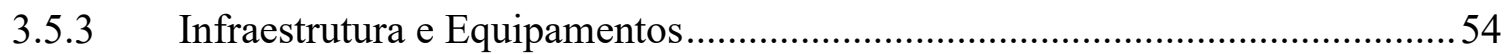

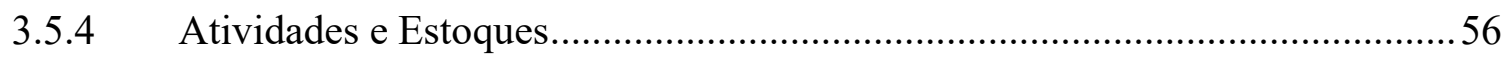

3.5.5 Quantidade de Veículos em Fim de Vida Útil no Distrito Federal ...................58

4 MODELO DE CENTRO DE REAPROVEITAMENTO PARA

VEÍCULOS LEVES EM FIM DE VIDA ÚTIL NO DF .......................................6 64

4.1 OBJETIVO DO PROCESSO DE REAPROVEITAMENTO ..................................... 65

4.2 CARACTERIZAÇÃO DO PROCESSO DE REAPROVEITAMENTO .................66

4.3 DESCRIÇÃO DO PROCESSO DE REAPROVEITAMENTO ................................68

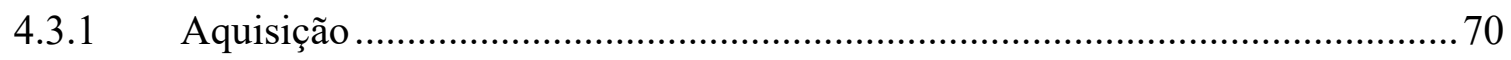

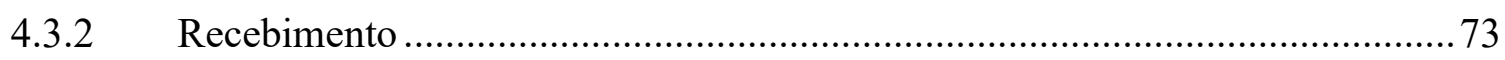

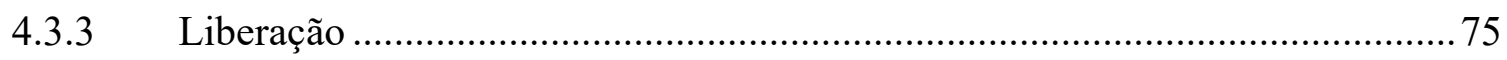

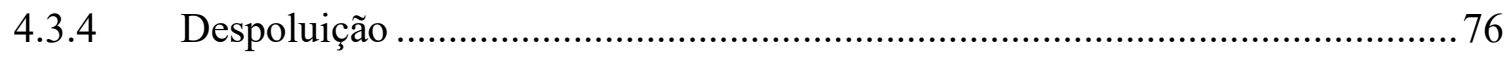

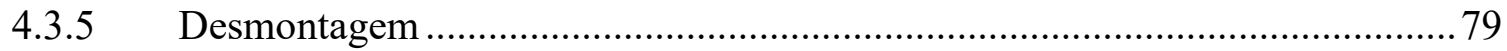

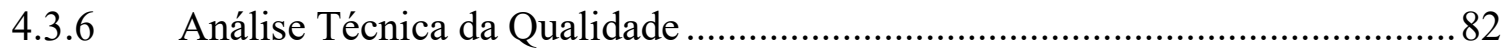

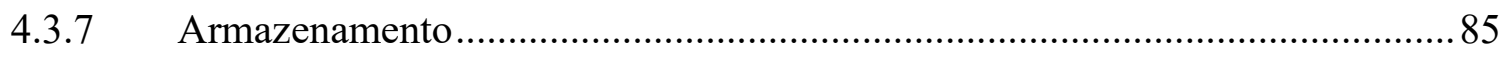

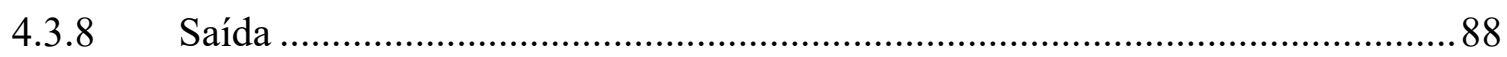

4.4 CARACTERIZAÇÃO DOS RECURSOS HUMANOS .......................................... 90

4.4.1 Quantidade e Capacitação dos Recursos Humanos .......................................... 91

4.4.2 Divisão das Tarefas dos Recursos Humanos ......................................................92

4.5 CARACTERIZAÇÃO DE EQUIPAMENTOS …................................................93

4.6 CARACTERIZAÇÃO DA INFRAESTRUTURA NECESSÁRIA..........................95

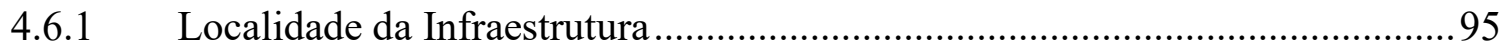

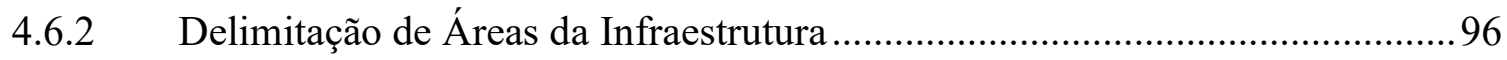

4.6.3 Proposição Preliminar de Arranjo Físico .......................................................... 97

4.7 MODELAGEM DO DIAGRAMA DO LAÇO CAUSAL .....................................99

4.7.1 Considerações Gerais sobre o Diagrama do Laço Causal ..................................99

4.7.2 Descrição do Diagrama do Laço Causal............................................................. 100

4.8 PROPOSTA PARA CONTROLE DAS INFORMAÇÕES ….............................. 109

5 CONCLUSÕES GERAIS E RECOMENDAÇÕES PARA PESQUISAS

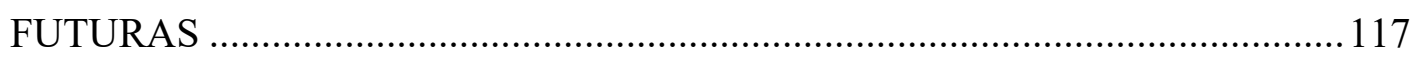

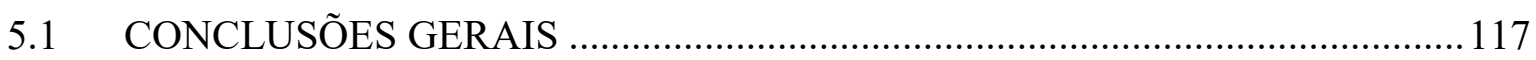

5.2 RECOMENDAÇÕES PARA PESQUISAS FUTURAS .................................... 121 
REFERÊNCIAS BIBLIOGRÁFICAS 123

APÊNDICE A: QUESTIONÁRIO DA PESQUISA DE CAMPO 130

APÊNDICE B: DIVISÃO DE TAREFAS PELAS PESSOAS.. 131

ANEXO A: UNIDADES DE USO E OCUPAÇÃO DO SOLO. 134 


\section{LISTA DE TABELAS}

Tabela 2.1 Comparação da idade dos veículos em fim de vida útil nos países ................... 23

Tabela 3.1 Relação dos materiais removidos na etapa de despoluição por autor................. 36

Tabela 3.2 Estações de trabalho para desmontagem de veículos em fim de vida ............... 39

Tabela 3.3 Tamanho e tipo de arranjo físico em centros de reaproveitamento .................... 43

Tabela 3.4 Capacidade em centros de reaproveitamento .................................................. 44

Tabela 3.5 Número de empresas registradas no Distrito Federal por CNAE...................... 48

Tabela 3.6 Número de empresas de CNAE 4530-7/04 registradas por RA ........................ 49

Tabela 3.7 Quantidade de veículos leiloados por ano como sucatas ...................................59

Tabela 3.8 Quantidade de veículos em circulação com idade avançada por ano ................. 60

Tabela 3.9 Quantidade de veículos em fim de vida útil no DF por ano ..............................61

Tabela 3.10 Consolidação dos dados da demanda anual estimada para três cenários......... 62

Tabela 4.1Objetivos do centro de reaproveitamento de veículos em fim de vida útil ........ 66

Tabela 4.2 Lista de tarefas para aquisição de veículos no centro de reaproveitamento ...... 72

Tabela 4.3 Lista de tarefas para recebimento de veículos no centro de reaproveitamento . 75

Tabela 4.4 Lista de tarefas para liberação de veículos no centro de reaproveitamento ...... 76

Tabela 4.5 Lista de tarefas para despoluição de veículos no centro de reaproveitamento .. 78

Tabela 4.6 Lista de tarefas para desmontagem de veículos no centro de reaproveitamento 81

Tabela 4.7 Lista de tarefas para análise técnica de peças no centro de reaproveitamento .. 84

Tabela 4.8 Lista de tarefas para armazenagem de peças no centro de reaproveitamento ... 87

Tabela 4.9 Lista de tarefas para saída de peças do centro de reaproveitamento .................. 90

Tabela 4.10 Descrição das principais tarefas da divisão de funções proposta .................... 92

Tabela 4.11 Definição dos equipamentos mecânicos essenciais por atividade proposta .... 94

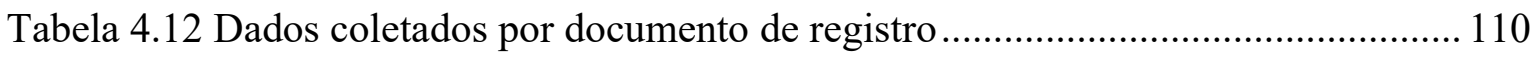

Tabela 4.13 Descrição e fórmula de informações consolidadas....................................... 113 


\section{LISTA DE FIGURAS}

Figura 1.1 Etapas da Design Science Research utilizadas pela pesquisa e suas saídas........ 7

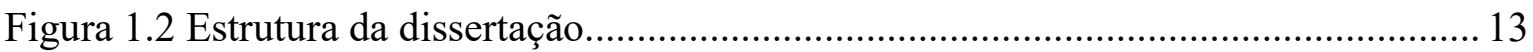

Figura 2.1 Fluxo básico da logística direta e da logística reversa ..................................... 16

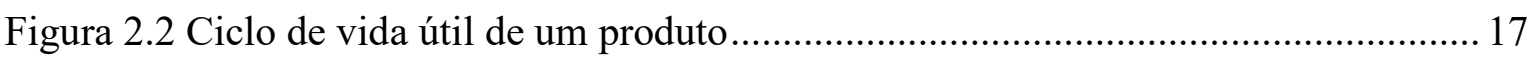

Figura 2.3 Curva generalizada do ciclo de vida mercadológico do produto ....................... 19

Figura 2.4 Fluxo dos canais reversos de pós-venda e de pós-consumo ...............................2 20

Figura 2.5 Percentual de automóveis e camionetas do total de veículos (a) Brasil e (b) DF

Figura 3.1Prazos para realização das principais atividades de acordo com a regulamentação

Figura 3.2 Cadeia produtiva de veículos com foco no fim de vida útil............................. 30

Figura 3.3 Hierarquia das estratégias de reaproveitamento de veículos em fim de vida .... 34

Figura 3.4 Área de despoluição de veículos na Renova Ecopeças ..................................... 37

Figura 3.5 Estações de trabalho para desmontagem de veículos em fim de vida................. 38

Figura 3.6 Área de desmontagem de veículos na Renova Ecopeças ................................... 39

Figura 3.7 Arranjo físico proposto para desmontagem na Coréia ...................................... 42

Figura 3.8 Mapa conceitual do sistema de informação do estado de São Paulo para

logística reversa de veículos leves em fim de vida útil .................................................... 46

Figura 3.9 Combinações de atividades das empresas de reaproveitamento de veículos ..... 47

Figura 3.10 Resíduos próximos às vias de trânsito de Taguatinga....................................... 50

Figura 3.11 Resíduos próximos às vias de trânsito de Sobradinho .....................................51

Figura 3.12 Disposição de veículos em desmontagem na via de circulação (Taguatinga) . 51

Figura 3.13 Disposição de veículos em desmontagem na via de circulação (Ceilândia).... 52

Figura 3.14 Vista aérea do Setor H Norte em Taguatinga Distrito Federal ......................... 54

Figura 3.15 Vista frontal de empresa no Setor H Norte em Taguatinga Distrito Federal ... 54

Figura 3.16 Balcão e prateleiras na área interna (a) Taguatinga e (b) Sobradinho .............. 55

Figura 3.17 Prateleiras organizadas por modelo em Sobradinho (a) Ecosport e (b) Omega

Figura 3.18 Veículos em desmontagem na área interna (a) Taguatinga e (b) Ceilândia..... 56

Figura 3.19 Modelo da quantidade de veículos em fim de vida útil por cenário 61

Figura 4.1 Processo de jobbing entre os tipos de processos por volume e variedade ......... 68

Figura 4.2 Descrição do processo de reaproveitamento de veículos em fim de vida útil ... 69 
Figura 4.3 Representação da organização do estoque por tipo, marca e modelo de peça... 86 Figura 4.4 Arranjo físico preliminar proposto pelo modelo de centro de reaproveitamento

Figura 4.5 Loop B1 de balanceamento dos veículos para transporte .............................. 101

Figura 4.6 Loop B2 de balanceamento dos veículos em recebimento................................ 102

Figura 4.7 Loop B3 de balanceamento dos recursos para despoluição .............................. 103

Figura 4.8 Loop B4 de balanceamento dos recursos para desmontagem ......................... 103

Figura 4.9 Loop B5 de balanceamento dos recursos para análise técnica......................... 104

Figura 4.10 Loop B6 de balanceamento dos recursos para tratamento ............................. 105

Figura 4.11 Loop B7 de balanceamento do veículo para encaminhamento de peças não

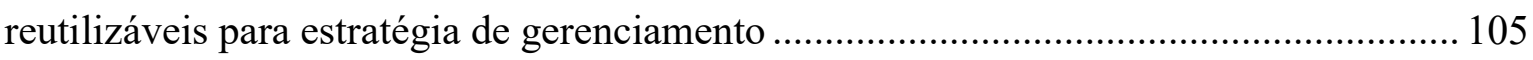

Figura 4.12 Loop B8 de balanceamento dos recursos humanos....................................... 106

Figura 4.13 Diagrama do laço causal para problema do modelo de centro de

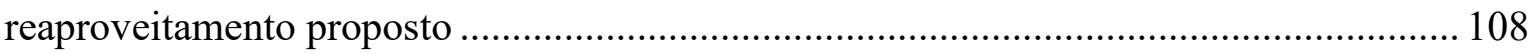

Figura 4.14 Documentos do processo de reaproveitamento de veículos leves proposto .. 109 Figura 4.15 Integração dos sistemas de informação do centro de reaproveitamento proposto 


\section{LISTA DE SIGLAS E ABREVIAÇÕES}

ADERA - Associação Brasileira de Desmontagem e Reciclagem de Veículo

AJUFE - Associação dos Juízes Federais do Brasil

ANFAVEA - Associação Nacional dos Fabricantes de Veículos Automotores

CAT - Centro Autorizado de Tratamento

CesviAuto - Centro de Reciclagem de Veículos

CLT - Consolidação das Leis do Trabalho

CNAE - Classificação Nacional de Atividades Econômicas

CNJ - Conselho Nacional de Justiça

CNseg - Confederação Nacional das Empresas de Seguros Gerais, Previdência Privada e

Vida, Saúde, Suplementar e Capitalização

CNT - Confederação Nacional do Transporte

CNSP - Conselho Nacional de Seguros Privados

CONTRAN - Conselho Nacional de Trânsito

CREA - Conselho Regional de Engenharia e Agronomia

DENATRAN - Departamento Nacional de Trânsito

DETRAN-DF - Departamento de Trânsito do Distrito Federal

DETRAN-GO - Departamento de Trânsito do Goiás

DETRAN-MS - Departamento de Trânsito do Mato Grosso do Sul

DETRAN-SP - Departamento de Trânsito de São Paulo

DETRAN-PR - Departamento de Trânsito do Paraná

DETRAN-RS - Departamento de Trânsito do Rio Grande do Sul 
DETRAN-SC - Departamento de Trânsito de Santa Catarina

DETRAN-TO - Departamento de Trânsito do Tocantins

FENABRAVE - Federação Nacional da Distribuição de Veículos Automotores

FenSeg - Federação Nacional de Seguros Gerais

IDIS - Internacional Dismantling Information System

IMDS - Internacional Material Data System

IPVA - Imposto sobre a Propriedade de Veículos Automotores

LUOS - Lei Complementar de Uso e Ocupação do Solo

MDIC - Ministério do Desenvolvimento da Indústria e do Comércio Exterior

RA - Região Administrativa

RenovAR - Programa de Renovação de Frota de Caminhões

SEF-DF - Secretaria de Estado de Fazenda do Distrito Federal

SINDICOM - Sindicato dos Comerciários do Distrito Federal

SINDICOR-DF - Sindicato dos Corretores de Seguros, Empresas Corretoras de Seguro, Capitalização e Previdência Privada no Distrito Federal

SINDIRVE - Sindicato das Indústrias Mecânicas, Reparadoras de Automóveis, Caminhões, Tratores, Motos e Autopeças do Distrito Federal

SUSEP - Superintendência de Seguros Privados

UOS - Unidades de Uso e Ocupação de Solo 


\section{INTRODUÇÃO}

\subsection{CONTEXTUALIZAÇÃO}

Soluções para conciliar o aumento na quantidade e na variedade com a redução do tempo de vida, útil e mercadológico, dos produtos emergiram nos países desenvolvidos em virtude da evolução da consciência ambiental, do encolhimento da área para disposição de resíduos e do esgotamento dos recursos naturais.

Nesse cenário, a logística reversa ganhou força dado que através do planejamento, da operação e do controle do fluxo de retorno dos materiais e das informações logísticas correspondentes, ela pode proporcionar um aumento da vida útil do produto ao reinserí-lo no mercado secundário ou no processo produtivo, sendo uma ferramenta importante para ganhos ambientais, sociais e econômicos (MONTEIRO et al., 2001; MANSOUR et al., 2010; VALLE; DE SOUZA, 2014).

No caso dos veículos leves em fim de vida útil, especificamente, a preocupação se originou na década de 1990 principalmente nos Estados Unidos, mas realmente ganhou força nos anos 2000 quando a União Europeia publicou a Diretiva 2000/ 53/ EC (CRUZ-RIVERA, 2008). Ela mostrou a necessidade de mudar radicalmente o modelo da logística reversa desse produto para alcance das metas de desempenho estipuladas para reutilização, recuperação e reciclagem (MERKISZ-GURANOWSKA, 2011).

Nesse contexto, a natureza descentralizada do mercado automobilístico promoveu um movimento generalizado na indústria de veículos para o cumprimento das exigências jurídicas, em especial nos países exportadores de veículos para a União Europeia (CRUZRIVERA; ERTEL, 2009). Em 2005, o Japão também promulgou uma lei semelhante que incentivou a reciclagem de veículos leves em fim de vida útil e tornou o país também referência no assunto.

Além de estimuladas pelo crescimento da regulamentação, as empresas passaram a ver oportunidades comerciais na coleta, reutilização e reciclagem desses materiais (MERKISZGURANOWSKA, 2011). E, assim, diversos foram os países, desenvolvidos e em desenvolvimento, que elaboraram as suas próprias legislações e os seus próprios modelos de sucesso para o reaproveitamento dos veículos leves em fim de vida útil (CRUZRIVERA; ERTEL, 2009; BERZI et al., 2013; AHMED et al., 2014; AZMI et al., 2013). 
Esse fato já reforça a importância que as legislações têm tido nesse processo de transformação - a de impulsionar a mudança de paradigma das empresas. Elas podem possuir formas de estruturação diferentes, como é o caso dos Estados Unidos, que possuem várias legislações estaduais e municipais ao invés de uma nacional; mas observa-se que são essenciais para o estágio inicial de implementação, até que as empresas percebam as oportunidades comerciais.

No Brasil, existem inúmeras empresas trabalhando há décadas com o tratamento de veículos em fim de vida útil nos diferentes estados. Além disso, trabalhos sobre tecnologias e materiais que facilitam a reciclagem de veículos foram feitos por Medina, Naveiro e Malafaia (2007) e Medina e Naveiro (2009).

Ademais, Mildemberger (2012) fez um levantamento do panorama e das dificuldades do reaproveitamento de veículos para o estado do Paraná, e Monteiro et al. (2015) o fizeram em âmbito nacional. Mildemberger et al. (2015) chegaram, inclusive, a avaliar uma proposta de reciclagem de veículos para o estado do Paraná tendo como base a experiência de uma cidade da Alemanha.

Com certeza, esses estudos foram reforçados pela discussão provocada pela Lei 12.305/ 2010 - Política Nacional dos Resíduos Sólidos -, que estabeleceu um direcionamento no que diz respeito a resíduos sólidos e iniciou a preocupação com o descarte de baterias, pneus, óleos lubrificantes e eletrônicos. No entanto, mais recente e especificamente, foi somente a Lei 12.977/ 2014 que abordou, em âmbito nacional, os veículos em fim de vida útil, formalizando a preocupação com a necessidade de mudanças.

Felizmente, observa-se que ela contempla algumas das boas práticas adquiridas em outros países em anos de experimentação e evolução, estabelecendo os requisitos para registro e operação de centros de reaproveitamento, definindo os órgãos executivos de trânsito dos estados e do Distrito Federal como os responsáveis pelo controle dessa atividade, propondo a utilização de um sistema de informação para rastreabilidade dos materiais.

Entretanto, ela não orienta detalhadamente a operação das empresas tampouco dos controladores. Sendo assim, espera-se que os estados também publiquem leis, decretos e portarias no sentido de estruturar a condução do reaproveitamento de veículos leves em fim de vida útil para atendimento dessa regulamentação, tendo em vista as especificidades da sua localidade. 
O estado de São Paulo foi o pioneiro, com amparo da Lei 15.276/ 2014, do Decreto 60.150/ 2014 e da Portaria DETRAN-SP 510/ 2015, em realizar o cadastramento das empresas habilitadas e exigir o fechamento das que não atendiam às especificações normativas. Por isso e pelas boas práticas alcançadas nos três anos de funcionamento do seu modelo de reaproveitamento, observadas em pesquisa de campo, o estado é considerado a referência nacional.

Por outro lado, o Distrito Federal, onde está localizada a capital do país, encontra-se com desenvolvimento bastante embrionário, com as seguintes características: ausência de orientação e condução pelo órgão executivo de trânsito (DETRAN-DF), desalinhamento e falta de liderança dos sindicatos, aversão à mudança por parte dos empresários, combinação de atividades complementares ao reaproveitamento e falta de cooperação entre as empresas da cadeia de reaproveitamento.

Com a visão mais voltada para dentro dos centros de reaproveitamento, a situação ainda é mais crítica: falta de padronização e estruturação das atividades, baixa preocupação com os impactos ambientais provocados pela operação, falta de organização e controle do estoque, baixa quantidade e capacitação de pessoal, baixa disponibilidade de equipamentos e de tecnologias da informação, pequena organização do espaço físico e falta de registro da operação realizada.

Assim, percebe-se que os modelos internacionais e nacionais existentes não atendem imediatamente à realidade específica do Distrito Federal, em virtude das restrições que não conseguiriam ser modificadas no estágio inicial. Complementarmente, não foram encontrados estudos e pesquisas relacionados a esse contexto específico, mesmo havendo um amplo mercado de empresas que trabalham com tratamento, desmontagem, reciclagem de veículos leves em fim de vida útil e comercialização de peças automotivas.

Diante deste cenário, surge o problema de pesquisa: O que poderia orientar as empresas de reaproveitamento de veículos leves em fim de vida útil do Distrito Federal a realizarem sua operação de acordo com a legislação adequada e as boas práticas e, também, o órgão competente a controlar e fiscalizar centros dessa natureza? 


\subsection{OBJETIVOS}

\subsubsection{Objetivo Geral}

O objetivo desse trabalho é propor um modelo de centro de reaproveitamento de veículos leves em fim de vida útil, com definição de atividades, documentos, equipamentos, pessoas e arranjo físico, tendo em vista as boas práticas internacionais e nacionais, a regulamentação aplicável e o contexto das empresas de reaproveitamento do Distrito Federal.

\subsubsection{Objetivos Específicos}

Como objetivos específicos dessa dissertação, tem-se:

- Identificar as boas práticas internacionais para reaproveitamento de veículos leves em de fim de vida útil;

- Identificar as práticas de referência nacional para reaproveitamento de veículos leves em fim de vida útil no estado de São Paulo;

- Identificar as restrições e os requisitos estipulados na regulamentação existente para a atividade de reaproveitamento de veículos leves em fim de vida útil;

- Identificar a realidade de organização e operação das empresas de reaproveitamento do Distrito Federal;

- Propor orientações para coleta de dados e controle das informações para o uso de ferramentas de simulação no aprimoramento do modelo proposto.

\subsection{JUSTIFICATIVA}

A estruturação adequada de centros de reaproveitamento de veículos leves em fim de vida útil é uma medida que visa consubstanciar um conjunto de impactos ambientais, sociais, legais e econômicos.

Por impactos ambientais entende-se que o reaproveitamento de veículos pode reduzir as emissões de gases estufa ao diminuir o número de veículos antigos em circulação e, consequentemente, aumentar a qualidade do ar; evitar ambientes propícios para disseminação de doenças ao retirar os veículos abandonados das vias e reduzir a quantidade de veículos dos depósitos abertos; estender ao máximo o ciclo de vida dos materiais contidos nesse tipo de produto; impulsionar o descarte mínimo, consciente e adequado e, com isso, reduzir o volume de resíduos nos lixões e aterros sanitários. 
É possível obter resultados sociais no sentido de reduzir os índices de doenças respiratórias provocadas por poluição do ar; de acidentes ocasionados por veículos antigos; de crimes provocados para alimentar o mercado ilegal de desmontagem de veículos para venda de peças usadas; de melhorar a mobilidade urbana, com a retirada de veículos abandonados nas vias de circulação; e, também, de incentivar a formação e a formalização profisssional de funcionários.

Dos impactos legais, pode-se colocar o cumprimento do papel do Estado como agente normativo e regulador da atividade econômica de reaproveitamento de veículos leves em fim de vida útil para as funções de planejamento, incentivo e fiscalização, tendo em vista a definição das regulamentações nacional e local, bem como a preparação dos órgãos executivos de trânsito para o desempenho do controle.

Por fim, o reaproveitamento de veículos proporciona externalidades econômicas positivas, como: incentivo à cadeia produtiva de desmontagem e reciclagem de veículos em fim de vida e ao mercado lícito de peças usadas e de materiais reciclados; melhoria na manutenção da frota tendo em vista a formação de ambiente adequado ao seguro popular, aquele que utiliza peças usadas para manutenção de veículos segurados; impulso à renovação de veículos em caso de fomento estatal para entrega de veículos com idade avançada; e resulta em maior arrecadação por parte do Estado, dada a regularização das atividades empresariais.

Além desse conjunto de efeitos positivos do reaproveitamento de veículos leves em fím de vida, a modelagem de um centro dessa natureza no contexto do Distrito Federal é uma iniciativa que visa proporcionar conhecimento para o órgão executivo de trânsito regular, controlar e fiscalizar mais facilmente as empresas envolvidas no âmbito da Lei 12.977/ 2014, bem como auxiliar as próprias empresas a se adaptarem e a regularizarem o seu processo de acordo com as boas práticas internacionais e nacionais, e as legislações necessárias.

Concluindo, no ambiente acadêmico e científico, esse trabalho objetiva agregar aos estudos já existentes relacionados à logística reversa de veículos leves em fím de vida útil, uma pesquisa aplicada à realidade de empresas no Distrito Federal na qual se pretende mostrar que é possível modelar um centro de reaproveitamento de veículos capaz de aplicar boas práticas nacionais e internacionais, atender às legislações e regulamentações necessárias, tendo em vista o contexto existente da região - restritivo e limitado. 


\subsection{MÉTODO DE PESQUISA}

No que diz respeito à finalidade, essa dissertação foi uma pesquisa aplicada, que visou adquirir conhecimentos com objetivo de resolver problemas percebidos no âmbito da população. Por outro lado, segundo o seu nível de explicação, a pesquisa foi exploratória em virtude de ter tido como propósito proporcionar maior familiaridade com o problema, com vistas a torná-lo mais explícito (GIL, 2010).

O método adotado nessa dissertação foi a design science research que, como método de pesquisa orientado à solução de problemas, buscou, a partir do entendimento do problema, construir um artefato (modelo) que permitisse transformar situações, alterando suas condições para condições melhores ou desejáveis (DRESCH; LACERDA; ANTUNES, 2015).

A abordagem da pesquisa foi de natureza qualitativa, visto que os dados não foram numéricos mas descritivos em grande parte da pesquisa e que tampouco houve tratamento estatístico. Em relação às técnicas para coleta de dados houve emprego de múltiplas fontes de evidência, como propõem Yin (2010) e Cauchick (2007), com utilização de entrevistas não estruturadas, semiestruturadas, observação, registros empresariais e documentos como relatórios e estudos.

\subsubsection{Etapas do Trabalho}

Tendo em vista as classificações desse estudo e o método de pesquisa design science research escolhido como estratégica de orientação, foram conduzidas oito diferentes etapas, adaptadas das propostas por Dresch, Lacerda e Antunes (2015), ilustradas pela Figura 1.1. 


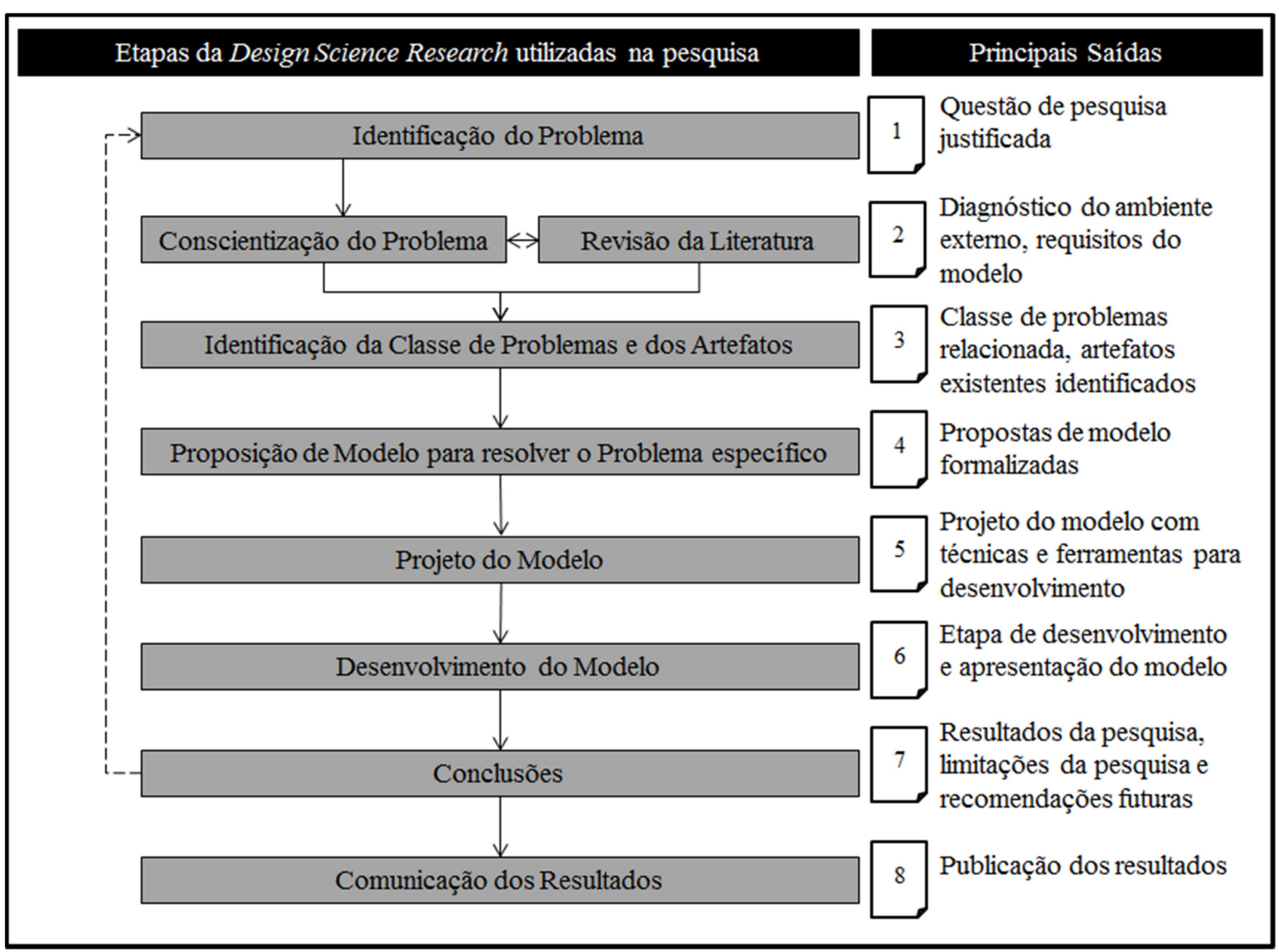

Figura 1.1 Etapas da Design Science Research utilizadas pela pesquisa e suas saídas Fonte: Dresch, Lacerda e Antunes (2015)

- $1^{\text {a }}$ Etapa: Identificação do problema

A identificação do problema ocorreu a partir da publicação da Lei 12.977/ 2014 e da constatação do despreparo das empresas de reaproveitamento do Distrito Federal para atendimento das suas exigências e do órgão competente para fiscalização dos aspectos apresentados. Nessa etapa, a questão de pesquisa foi, portanto, estipulada. Nessa dissertação, ela foi apresentada nesse capítulo de introdução (seção 1.1) e a, também apresentada anteriormente (seção 1.3), justificativa ressaltou a importância e a relevância de estudá-la.

- $2^{a}$ Etapa: Conscientização do problema e revisão da literatura

$\mathrm{Na}$ segunda etapa, para aprofundamento do problema escolhido, foram realizadas entrevistas não estruturadas com duas partes envolvidas no contexto externo dos centros de reaproveitamento: o Sindicato das Indústrias Mecânicas, Reparadoras de Automóveis, Caminhões, Tratores, Motos e Autopeças do Distrito Federal (SINDIRVE); e o órgão executivo de trânsito, o Departamento de Trânsito do Distrito Federal (DETRAN-DF). 
Em paralelo, foi realizada uma pesquisa bibliográfica sobre logística reversa de pósconsumo para produtos no final do ciclo de vida, a fim de delimitar conceitualmente o escopo no qual a pesquisa estaria englobada; e sobre os veículos leves - objeto de estudo -, com a classificação dos tipos existentes, o seu tempo de circulação até o fim de vida e os impactos gerados quando com idade avançada.

Também no ambiente externo e através de pesquisa bibliográfica, foram levantados os casos de sucesso internacionais, em países desenvolvidos e subdesenvolvidos, que dizem respeito a centros de reaproveitamento de veículos leves em fim de vida útil. No estado de São Paulo, foi feita uma pesquisa de campo a quatro empresas, com ênfase na Renova Ecopeças, com apoio de entrevista semiestruturada (Apêndice A) e observação.

Os aspectos legais relacionados ao reaproveitamento de veículos leves em fim de vida útil bem como os requisitos para operação de instalação desse tipo de atividade foram levantados para que o modelo desenvolvido atendesse às exigências definidas. Também foram pesquisadas as iniciativas estaduais, mesmo que não aplicáveis ao Distrito Federal, para que fosse possível compreender a evolução do tratamento desses veículos no país.

Por fim, a partir de pesquisa documental, com os dados da frota do Distrito Federal registrada no DENATRAN e da quantidade de veículos leiloados como sucata pelo DETRAN-DF, foi feita uma estimativa da tendência de crescimento da demanda para centros de reaproveitamento de veículos leves no Distrito Federal de acordo com os passos utilizados por Coelho et al. (2016), com intuito de reforçar a oportunidade de negócio existente e a possibilidade de melhoria do atendimento da demanda a partir da implementação do modelo.

A partir desse levantamento foi possível compreender a principal funcionalidade do artefato: indicar como o processo de reaproveitamento de veículos leves em fim de vida útil deve ocorrer para que atenda às legislações, às boas práticas nacionais e internacionais, dentro do contexto das empresas do Distrito Federal. Para isso, os elementos que precisaram ser delimitados foram atividades, pessoas, equipamentos, tecnologia da informação, espaço físico e documentos.

- $\quad 3^{\text {a }}$ Etapa: Identificação da classe de problemas e dos modelos relacionados

Classe de problemas pode ser definida, de acordo com Dresch, Lacerda e Antunes (2015), como a organização de um conjunto de problemas práticos ou teóricos que contenha os 
artefatos úteis para a ação nas organizações. No caso dessa dissertação, a partir da conscientização do problema e da revisão da literatura, foi definida a classe de problemas como o reaproveitamento de veículos leves em fim de vida útil.

Dentro dessa classe de problemas, foram identificados diferentes modelos internacionais e nacionais, com boas práticas, conforme comentado, que foram consolidados conjuntamente no capítulo de panorama do reaproveitamento de veículos leves em fim de vida útil. A identificação desses modelos confirmou a impossibilidade de eles, já avançados e com amplo uso de recursos, serem aplicados nos centros de reaproveitamento do Distrito Federal, em virtude das restrições que não conseguiriam ser modificadas no estágio inicial.

A identificação dos modelos já existentes orientou a modelagem do centro de reaproveitamento para o Distrito Federal, no sentido de tornar as proposições feitas pela pesquisa mais assertivas.

- $4^{\mathrm{a}}$ Etapa: Proposição de modelo para resolver o problema específico

A escolha pelo artefato modelo se deve ao fato de ele ser uma representação da realidade, que apresenta tanto as variáveis de determinado sistema como as suas relações (DRESCH; LACERDA; ANTUNES, 2015). Nesse caso, o modelo pode ser considerado uma descrição de como os processos de reaproveitamento de veículos leves em fim de vida útil devem ocorrer dentro dos centros que realizam esse tipo de atividades.

Dessa maneira, acredita-se que o modelo proposto, quando implementado na prática pelas empresas, possa alterar e melhorar a situação presente. Além disso, é esperado que ele sirva como fundamento para o controle e a fiscalização por parte do órgão competente.

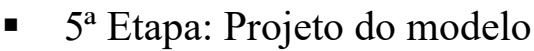

O desenvolvimento do modelo iniciou com a seleção de três unidades de análise no Distrito Federal, tendo em vista a localização nas regiões administrativas de maior concentração de centros de reaproveitamento, a disponibilidade e o interesse do proprietário responsável. O contato se deu por intermediação do SINDIRVE, para que não houvesse qualquer conflito no contato com esses atores.

Nelas, foram realizadas visitas técnicas com entrevistas semiestruturadas, com composição apresentada no Apêndice A. Também, todas as regiões nas quais as empresas estão localizadas foram observadas na pesquisa de campo realizada. Os resultados consolidados 
identificaram o detalhamento das características do ambiente interno do centro de reaproveitamento e foram apresentados na seção de diagnóstico das empresas do Distrito Federal.

- $6^{\mathrm{a}}$ Etapa: Desenvolvimento do modelo

Com base nos conhecimentos adquiridos anteriormente, foram delimitados os objetivos do processo de reaproveitamento de veículos leves em fim de vida útil modelado, conforme sugestão de Slack, Chambers e Johnston (2009), tendo em vista que o motivo de propor uma estrutura antes de ela ser realmente construída é assegurar que o seu funcionamento atenda ao que se almeja alcançar.

Em seguida, o processo foi caracterizado como de jobbing, de acordo com Slack, Chambers e Johnston (2009) dado que o volume de processo é relativamente baixo e as atividades podem ser modificadas durante o próprio processo de produção, em virtude da alta variedade do produto.

Logo após, a descrição das oito atividades (aquisição, recebimento, liberação, despoluição, desmontagem, análise técnica da qualidade, armazenamento e saída) propostas para o processo de reaproveitamento foi feita em forma de discussão com as exigências da legislação e com as boas práticas, internacionais e nacionais, anteriormente levantadas. A cada atividade descrita, foi elaborada uma tabela de consolidação com as tarefas a serem desempenhadas.

Delimitadas as atividades e tarefas, os recursos humanos foram caracterizados, tendo em vista elementos propostos por Slack, Chambers e Johnston (2009) para o projeto adequado do trabalho de pessoas - quantidade, capacitação e divisão das tarefas. A quantidade não foi alterada em relação ao diagnóstico realizado. Por outro lado, as orientações para capacitação e para divisão de tarefas foram propostas pelo modelo.

A caracterização dos equipamentos mecânicos e de tecnologia da informação considerou as atividades sugeridas pelo modelo e as boas práticas levantadas nas experiências internacionais e nacionais. Nesse caso, foi comentada a possibilidade de os centros utilizarem ferramentas alternativas de menor valor, desde que com mesma funcionalidade.

O modelo também sugeriu as possíveis localidades nas quais os centros de reaproveitamento podem funcionar a partir da Classificação Nacional de Atividades 
Econômicas (CNAE) e das delimitações do Projeto de Lei Complementar 79/ 2013 - Lei Complementar de Uso e Ocupação do Solo (LUOS) do DF, que está em estágio de revisão na câmara legislativa.

Entrando na divisão do espaço físico da infraestrutura, os tamanhos mínimos foram obtidos da Lei 2.108/ 1998 - Código de Edificações do Distrito Federal, de Cruz-Rivera (2008) e de Neufert (2013), entretanto, as áreas foram modificadas, tendo em vista o estágio inicial dos centros do Distrito Federal, com grande restrição de tamanho para infraestrutura.

Finalizada a proposição das características que os centros de reaproveitamento devem possuir, como contribuição para os estágios posteriores, foi desenvolvido um diagrama do laço causal no sentido de orientar os atores envolvidos a compreenderem as variáveis chaves, bem como o relacionamento entre elas, e a estrutura do escopo do modelo proposto, conforme Sterman (2000).

Por fim, a partir da ilustração pelo diagrama do laço causal, e das descrições anteriores sobre as atividades, pessoas, equipamentos, tecnologias e infraestrutura dos centros de reaproveitamento, foram colocadas orientações para a coleta de dados e o controle das informações. Assim, acredita-se que os modelos posteriores poderão partir de decisões amparadas nelas e em simulações realizadas a partir delas.

Diferentemente do proposto por Dresch, Lacerda e Antunes (2015), nessa dissertação não houve previsão de implementação do modelo para mensuração dos resultados de desempenho obtidos após a adequação do processo de reaproveitamento, em virtude do prazo delimitado. Dessa maneira, a avaliação do modelo desenvolvido foi colocada como possibilidade para pesquisas futuras. Apenas a partir dela será possível explicitar efetivamente os limites do modelo e as suas condições de utilização.

Nos estágios posteriores, com a disponibilidade de dados, será possível realizar a avaliação do modelo através de ferramentas de simulação, sem haver necessidade de implementação prática das sugestões para conferência da adequabilidade dos resultados. Por isso, o modelo desenvolveu o diagrama do laço causal e propôs a coleta de dados especificada.

- $7^{\mathrm{a}}$ Etapa: Conclusões

As conclusões que foram apresentadas consolidaram a pesquisa realizada nessa dissertação de mestrado, declarando os resultados obtidos e propondo possibilidades para pesquisas 
futuras. Não pode ser feito, conforme proposto por Dresch, Lacerda e Antunes (2015), a generalização do modelo para que, o conhecimento gerado na realidade específica do Distrito Federal pudesse ser utilizado diretamente em outros estados com características semelhantes, através de pensamento indutivo. Esse estudo foi colocado como oportunidade para pesquisas futuras.

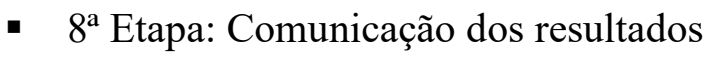

Nesta dissertação, a comunicação dos resultados prevista por Dresch, Lacerda e Antunes (2015) ocorreu com a defesa acadêmica da pesquisa realizada, bem como com a publicação de artigos relacionados em congressos e/ou revistas.

\subsection{ESTRUTURA DA DISSERTAÇÃO}

Essa dissertação foi dividida em cinco capítulos, incluindo este primeiro, o qual apresenta os aspectos gerais do tema trabalhado: contextualização do problema, objetivos da pesquisa, justificativas do trabalho a ser desenvolvido, o método a ser utilizado e as etapas que foram executadas.

O segundo capítulo abordou o referencial teórico necessário à delimitação do objeto de estudo da pesquisa. Nesse sentido, o conceito de logística reversa de pós-consumo e o de veículos leves no final do ciclo de vida foram apresentados. Os potenciais impactos em caso de não tratamento desse produto também foram discutidos.

Então, o terceiro capítulo teve como intuito fazer um panorama do reaproveitamento dos veículos leves em fim de vida útil, desde a apresentação das melhores práticas internacionais e nacionais até o diagnóstico da limitada realidade experimentada pelas empresas do setor no Distrito Federal.

Primeiramente os aspectos legais foram explicitados e, em seguida, a cadeia de reaproveitamento foi comentada com ênfase para as possíveis estratégias de gerenciamento dos materiais. Aprofundando no centro de reaproveitamento especificamente, as suas principais características (capacidade, atividades, infraestrutura, controle de informações) foram expostas. Por fim, o cenário dessas empresas no Distrito Federal foi exposto a partir de dados coletados em pesquisa de campo.

O quarto capítulo, a principal contribuição desta dissertação, contemplou o detalhamento do modelo proposto para que um centro de reaproveitamento, nessa localidade, atenda às 
legislações e às boas práticas, considerando as restrições existentes. Sugestões foram feitas para estruturação das atividades e tarefas, dos recursos humanos, dos equipamentos, do espaço físico e dos dados a serem coletados.

Ainda no capítulo quatro, foi apresentado o diagrama do laço causal para o escopo do centro de reaproveitamento proposto, no sentido de orientar os atores envolvidos a compreenderem as variáveis chaves, bem como o relacionamento entre elas, e a estrutura do problema. A partir da implementação do modelo proposto e da utilização do diagrama do laço causal, acredita-se que as futuras tomadas de decisão poderão ser quantitativas.

O último capítulo trouxe os resultados obtidos a partir da pesquisa realizada e as conclusões gerais discutidas a partir deles e fez sugestões para trabalhos futuros a fim de fomentar a continuidade da linha de pesquisa estudada. A Figura 1.2 ilustra a estrutura da dissertação de acordo com os tópicos discutidos em cada capítulo, bem como com o relacionamento deles com as principais saídas esperadas pela metodologia utilizada design science research.

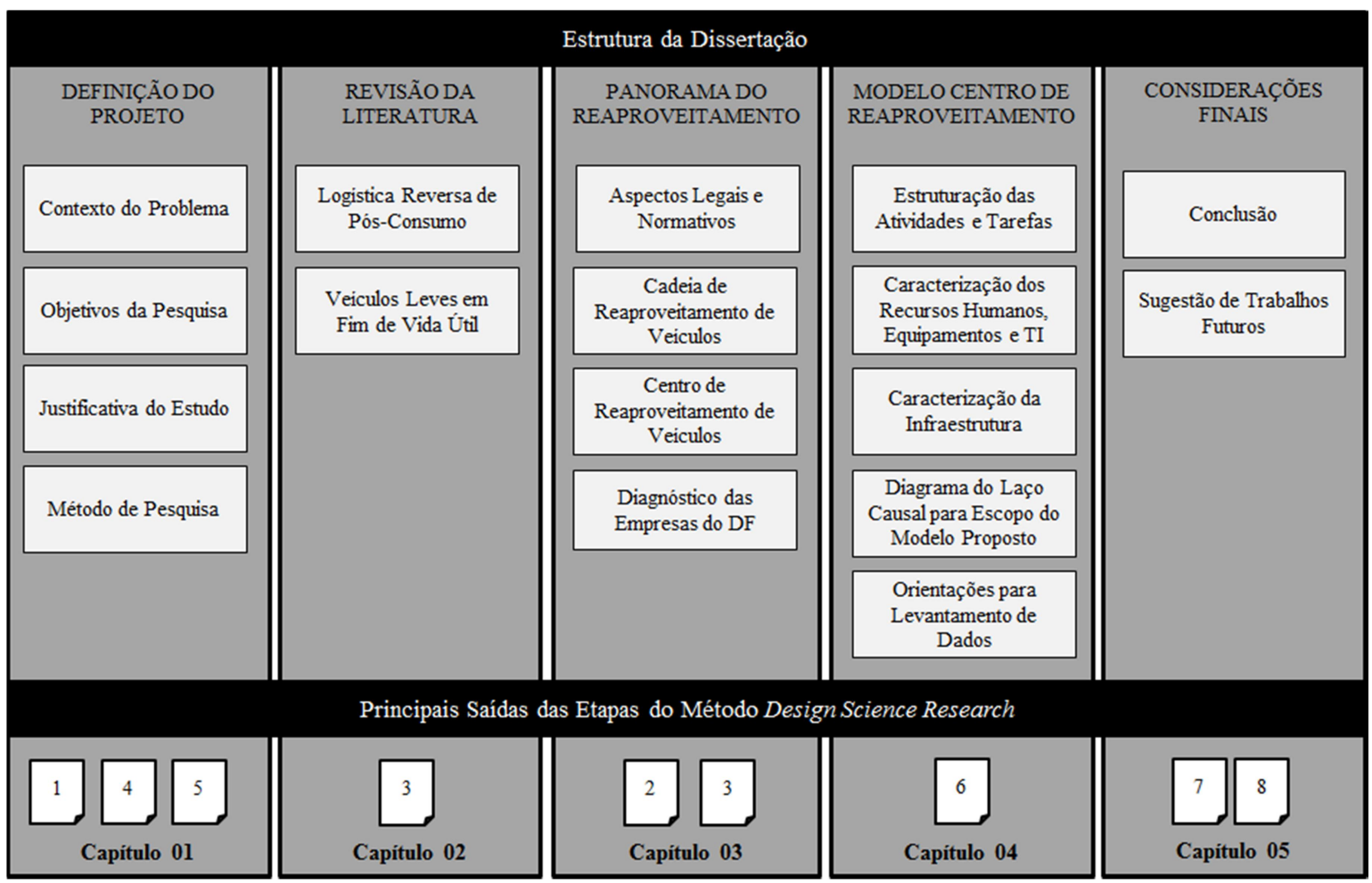

Figura 1.2 Estrutura da dissertação 


\section{LOGÍSTICA REVERSA DE VEÍCULOS LEVES EM FIM DE VIDA ÚTIL}

A proposição de um modelo para um centro de reaproveitamento de veículos em fim de vida útil exige a compreensão dos conceitos inseridos em seu contexto, para que seja possível reconhecer as referências internacionais e nacionais, bem como as legislações adequadas às condições do problema.

Sendo assim, esse capítulo inicia com a diferenciação da logística reversa em relação à direta e comenta o relacionamento dela com o ciclo de vida dos materiais. Enfatizando a etapa de fim de vida útil, a logística reversa de pós-consumo é apresentada como a classificação adequada, quando o produto finalizou sua utilidade primária.

Em seguida, os veículos leves em fim de vida útil, como produto propriamente dito, são caracterizados. Primeiramente as classificações consideradas como de veículo leve são especificadas. Em seguida, discute-se a idade a partir da qual um veículo passa a ser considerado em fim de vida útil. E, por fim, são apresentados os possíveis impactos causados por eles.

\subsection{LOGÍSTICA REVERSA}

\subsubsection{Logística Direta e Logística Reversa}

Ambas as logísticas, direta e reversa, são fases da logística empresarial (VALLE; DE SOUZA, 2014). Entretanto, Tibben-Lembke (2002) enfatiza que existem diferenças claras entre o fluxo logístico direto e o reverso. Assim, elas merecem ser conceituadas e compreendidas distintamente.

A utilização da logística direta remonta às épocas mais antigas da história documentada da humanidade (LEITE, 2009; CASTRO; SOUZA; BOLOVENTA 2012) e, de acordo com Ching (2006), o seu conceito inicial remete à Segunda Guerra Mundial, quando foi utilizado pelas forças armadas norte-americanas.

A logística direta é definida pelo Conselho de Profissionais de Gerenciamento de Cadeia de Suprimento como: "o processo de planejar, implementar e controlar os procedimentos para o eficiente e efetivo transporte e armazenamento de bens, incluindo serviços, e de informações relacionadas, do ponto de origem para o ponto de consumo com o propósito 
de atender aos requisitos dos clientes" (Council of Supply Chain Management Professionals, 2013).

Por outro lado, é consenso entre os autores - Rogers e Tibben-Lembke (1999), Leite (2009), Valle e De Souza (2014), Novaes (2015) - que os estudos de logística reversa são mais recentes. Os primeiros são encontrados nas décadas de 1970 e 1980, com foco mais restrito para reciclagem. A partir da década de 1990, aparecem com abordagens ambientais, ecológicas, de ordem legal, econômica, entre outras (TADEU et al., 2014).

Leite (2009, p.14) justifica:

"Nas últimas décadas, vivenciamos uma indiscutivel ânsia de lançamento de produtos e modelos em todos os setores empresariais em todas as partes do globo. Comparando a quantidade de modelos que compõem uma única categoria de produto com a quantidade adquirida há algumas décadas, é possivel constatar, sem dificuldade, um crescimento extraordinário. (...) Por outro lado, observa-se uma nítida redução no tempo de vida mercadológico e útil dos produtos em todos os setores da atividade humana."

Os impactos desse fenômeno - aumento na quantidade/ variedade dos produtos e redução do tempo de vida no mercado - foram tão marcantes que reforçaram a logística reversa, a área da logística que opera no sentido inverso, garantindo o retorno de produtos, materiais e peças a um novo uso, a um novo processo de produção ou a uma destinação adequada.

A Figura 2.1 mostra o fluxo de materiais na logística direta e na reversa. É possível observar que os canais de distribuição diretos são os responsáveis por movimentar os materiais até o ponto de consumo, passando pelas etapas de extração do insumo, manufatura, distribuição e comércio. Por outro lado, os canais reversos têm o papel de recolher os materiais, consolidá-los, inspecioná-los e definir uma destinação, podendo ser reciclagem, remanufatura, reúso, recondicionamento ou disposição final. 


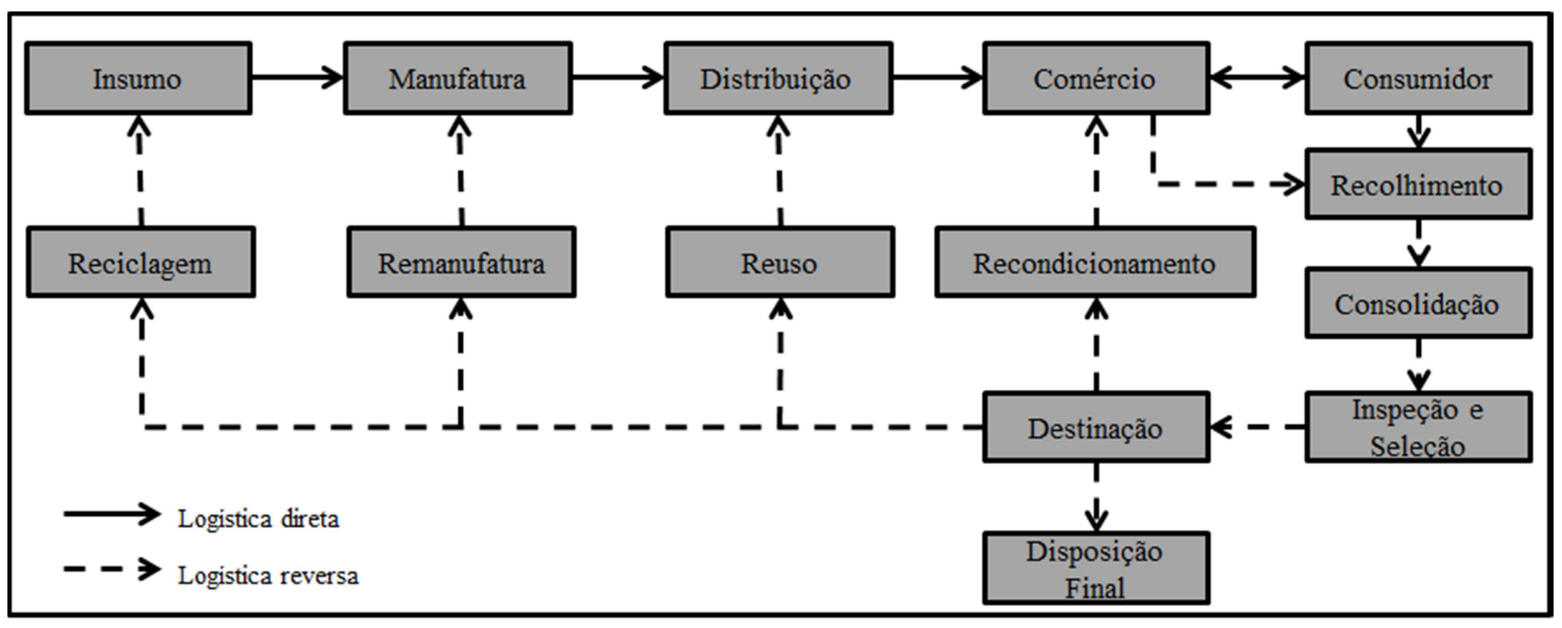

Figura 2.1 Fluxo básico da logística direta e da logística reversa Fonte: adaptado de Agrawal, Singh e Murtaza (2015)

Atualmente, existem grupos e conselhos formados especialmente para tratar das questões da logística reversa, tais como o Reverse Logistics and Sustainability Council nos Estados Unidos, o European Working Group on Reverse Logistics na Europa e o Conselho de Logística Reversa do Brasil.

Dessa maneira, diferentes são os conceitos elaborados e propostos pelos pesquisadores. De acordo com Tadeu et al. (2014) os principais são extensões do conceito do Conselho de Profissionais de Gerenciamento de Cadeia de Suprimento: "Logística reversa é um segmento especializado da logística focado na movimentação e no gerenciamento de produtos pós-venda e pós-consumo" (Council of Supply Chain Management Professionals, 2013).

O Conselho de Profissionais de Gerenciamento de Cadeia de Suprimento faz uma definição enxuta, entretanto outros autores aprofundam a conceituação, agregando a ela o seu escopo de interesse em relação à logística reversa (AGRAWAL; SINGH; MURTAZA, 2015). De forma detalhada, Leite (2009) conceitua como a área da logística empresarial que planeja, opera, controla o fluxo e as informações logísticas correspondentes, do retorno dos bens de pós-venda e de pós-consumo ao ciclo dos negócios ou ao ciclo produtivo, por meio dos canais de distribuição reversos, agregando-lhes valores de diversas naturezas: econômico, de prestação de serviços, ecológico, legal, logístico, de imagem corporativa, dentre outros.

Por outro lado, a Lei 12.305/ 2010 coloca a logística reversa como instrumento de desenvolvimento econômico e social caracterizado por um conjunto de ações de 
responsabilidade compartilhada. Valle e De Souza (2014) contribuem com a abordagem de processos, dizendo que ela incorpora as atividades operacionais, de gestão e de apoio que, de forma integrada e envolvendo os diversos atores, planejam e viabilizam a implementação das soluções mais adequadas para os resíduos.

Tadeu et al. (2014) reforçam o aspecto sustentável da logística reversa ao colocar que ela agrega ações ligadas à redução do uso de matérias-primas primarias até à destinação final correta dos produtos, materiais e embalagens com seu consecutivo reúso, reciclagem e produção de energia.

\subsubsection{Logística Reversa e o Ciclo de Vida do Produto}

O tipo de reprocessamento ou destinação de um produto depende do estágio em que ele entra no processo de logística reversa e de suas condições gerais (VALLE; DE SOUZA, 2014). Esse estágio pode ser relacionado à etapa na qual se encontra o produto no seu ciclo de vida.

De acordo com Valle e De Souza (2014), o ciclo de vida de um produto pode ser entendido como o conjunto das fases que compõem a história do produto, desde a extração de matérias-primas dos recursos naturais até a sua destinação final, como resume a Figura 2.2.

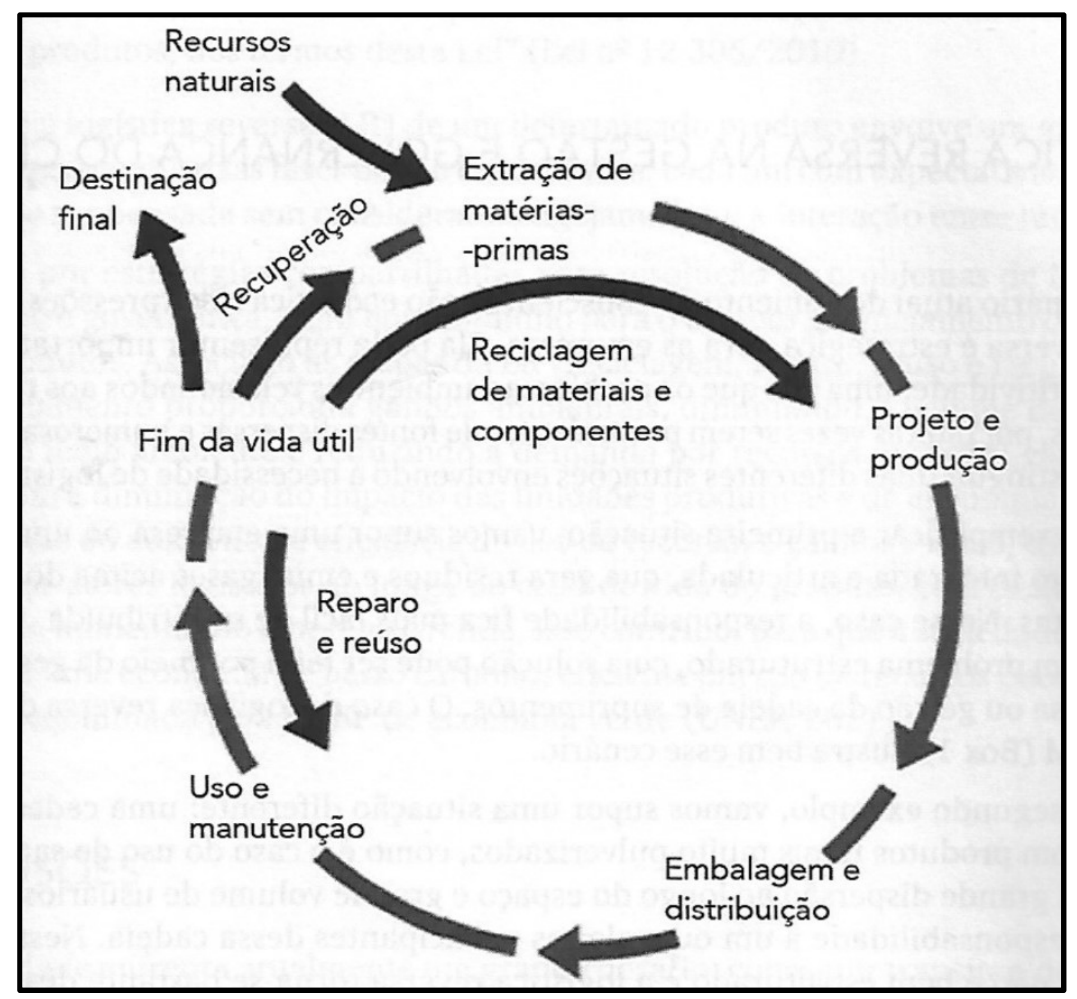

Figura 2.2 Ciclo de vida útil de um produto Fonte: Valle e De Souza (2014) 
A Lei 12.305/2010 atesta na mesma direção ao dizer que o ciclo de vida de um produto é um conjunto de etapas que envolvem o desenvolvimento do produto, a obtenção de matérias-primas e insumos, o processo produtivo, o consumo e a disposição final.

Do ponto de vista logístico, portanto, o ciclo de vida do produto não encerra com a sua entrega ao cliente ou com a finalização do seu uso (MONTEIRO et al., 2001). A logística reversa, em especial, contempla importantes etapas do ciclo de vida, como reparo e reúso, reciclagem de materiais e componentes, recuperação e destinação final (VALLE; DE SOUZA, 2014).

Isso porque, mesmo os produtos em fim de vida útil, possuem partes, componentes e materiais valiosos, que podem ser utilizados novamente ou podem retornar ao ciclo de produção. Por isso, as etapas de reaproveitamento são tão importantes no ciclo de vida de um produto (MANSOUR et al., 2010). Assim, a logística reversa pode proporcionar um aumento da vida útil do produto ao reinserí-lo no mercado secundário ou no processo produtivo, sendo uma ferramenta importante para ganhos ambientais e sociais possuindo um papel relevante para a gestão do ciclo de vida do produtos (VALLE; DE SOUZA, 2014).

O ciclo de vida mercadológico de um produto (VALLE; DE SOUZA, 2014) também está relacionado com a logística reversa visto que, como reconhece Leite (2009), o tempo de vida dos produtos no mercado está reduzindo e cada vez há mais produtos obsoletos em virtude de novos lançamentos. Ele é divido em fases - lançamento, crescimento, maturidade e saturação/ declínio -, como expõe Ballou (2006) e, quando atingem a última etapa, começam a ser substituídos. A Figura 2.3 ilustra a curva generalizada do ciclo de vida de mercado dos produtos. 


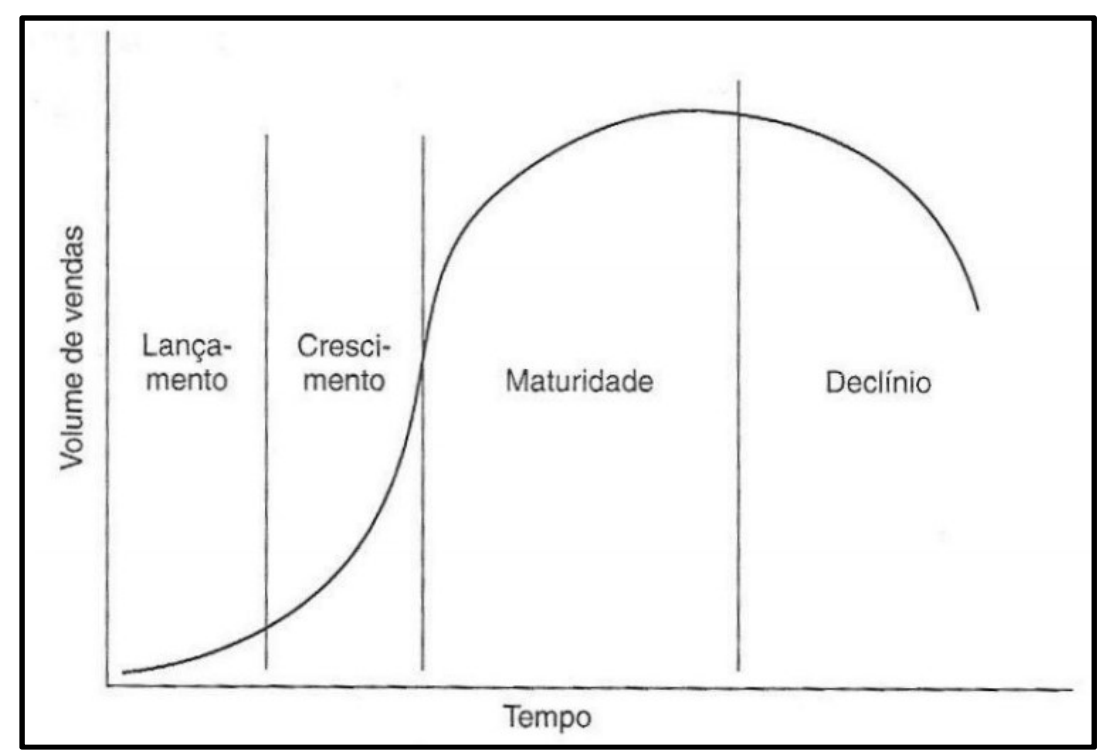

Figura 2.3 Curva generalizada do ciclo de vida mercadológico do produto Fonte: Ballou (2006)

Assim, há um aumento no volume de produtos descartados por fim de vida útil e/ ou por declínio no ciclo mercadológico que necessitam ser tratados pela logística reversa.

\subsubsection{Classificação da Logística Reversa}

Em função das fases do ciclo de vida do produto, a logística reversa pode ser classificada em: pós-venda ou pós-consumo. A logística reversa de pós-venda é constituída pelas diferentes formas e possibilidades de retorno de uma parcela de produtos, com pouco ou nenhum uso, que fluem no sentido inverso, motivados por problemas relacionados à qualidade em geral, a processos comerciais entre empresas ou à substituição de componentes (LEITE, 2009).

Já a logística reversa de pós-consumo é constituída do fluxo reverso de uma parcela de produtos e materiais originados do descarte, depois de finalizada sua utilidade primária (LEITE, 2009). Na maioria dos casos, porém, esses produtos não são descartados após seu uso pelo primeiro proprietário (NOVAES, 2015).

No caso dos automóveis, por exemplo, eles são vendidos no mercado de segunda mão e a comercialização continua diversas vezes, cobrindo vários anos, até que, finalmente, seu uso passa a ser antieconômico por falta de peças de substituição, custos elevados de manutenção, falta de segurança ou proibição legal de seu uso (NOVAES, 2015).

A Figura 2.4 esclarece o foco de atuação da logística reversa de pós-venda e de pósconsumo, bem como ilustra o possível relacionamento existente entre elas. Os produtos de 
pós-venda, como dito, retornam por garantia, comercialização e substituição de componentes, podendo ser encaminhados para conserto, estoque e posterior retorno ao ciclo de negócios, ou disposição final por validade de produto.

Por outro lado, os bens de pós-consumo ainda podem ser divididos em: fim de vida útil e em condições de uso. Estes serão encaminhados para o reúso em um mercado secundário, enquanto aqueles serão desmontados para que os seus componentes recebam o tratamento adequado (remanufatura, reciclagem, disposição final) para posterior venda de peças no mercado secundário. Os resíduos industriais, por fim, devem ser encaminhados à reciclagem e, em seguida, para o mercado secundário de matérias-primas para que seja encaminhado para o ciclo produtivo novamente.

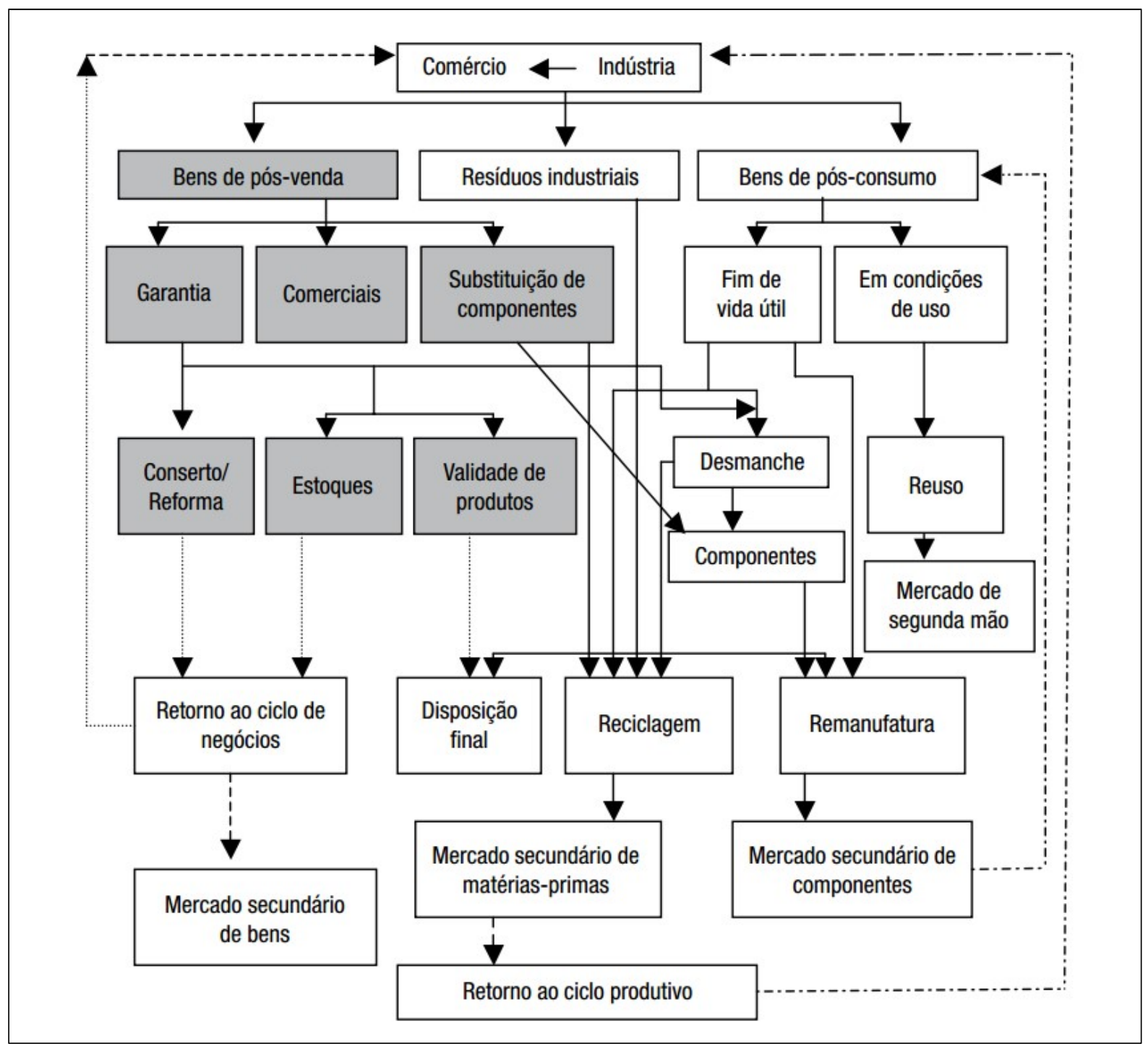

Figura 2.4 Fluxo dos canais reversos de pós-venda e de pós-consumo Fonte: Leite (2009) 


\subsection{VEÍCULOS LEVES EM FIM DE VIDA ÚTIL}

Os veículos são produtos característicos de uma sociedade evoluída e dinâmica (CASTRO; SOUZA; BOLOVENTA, 2012). São também um dos mais complexos produtos do mercado (CRUZ-RIVERA, 2008). Dessa maneira, é importante conhecer suas classificações, características e, também, os impactos que podem provocar quando em fim de vida útil.

\subsubsection{Classificação dos Veículos}

Diferentes tipos de veículos existem para variados usos possíveis. A Associação Nacional dos Fabricantes de Veículos Automotores (ANFAVEA, 2016), estratifica as empresas de veículos a depender do tipo de veículo que produzem: automóveis, comerciais leves, caminhões e ônibus.

Por outro lado, a Lei 9.503/ 1997, que institui o Código de Trânsito Brasileiro, utiliza mais categorias de classificação: quanto à tração (automotor, elétrico, de propulsão humana, de tração animal, reboque e semirreboque), quanto à espécie (passageiros, carga, misto, de competição, de tração) e quanto à categoria (oficial, particular, de aluguel, de aprendizagem). Esse projeto de pesquisa abordou os veículos automotores, de passageiros e mistos, dos tipos automóveis e camionetas, conforme apresentados pela Lei 9.503/ 1997:

- Automóvel: veículo automotor destinado ao transporte de passageiros, com capacidade para até oito pessoas.

- Camioneta: veículo misto destinado ao transporte de pessoas e carga no mesmo compartimento.

O volume desses tipos de veículos, de acordo com os dados de 2015 do DENATRAN, representa 58\% do total de 90.686 .936 veículos brasileiros. No Distrito Federal, o percentual é ainda maior, representando $76 \%$ dos 1.649 .563 veículos existentes, como mostra a Figura 2.5.
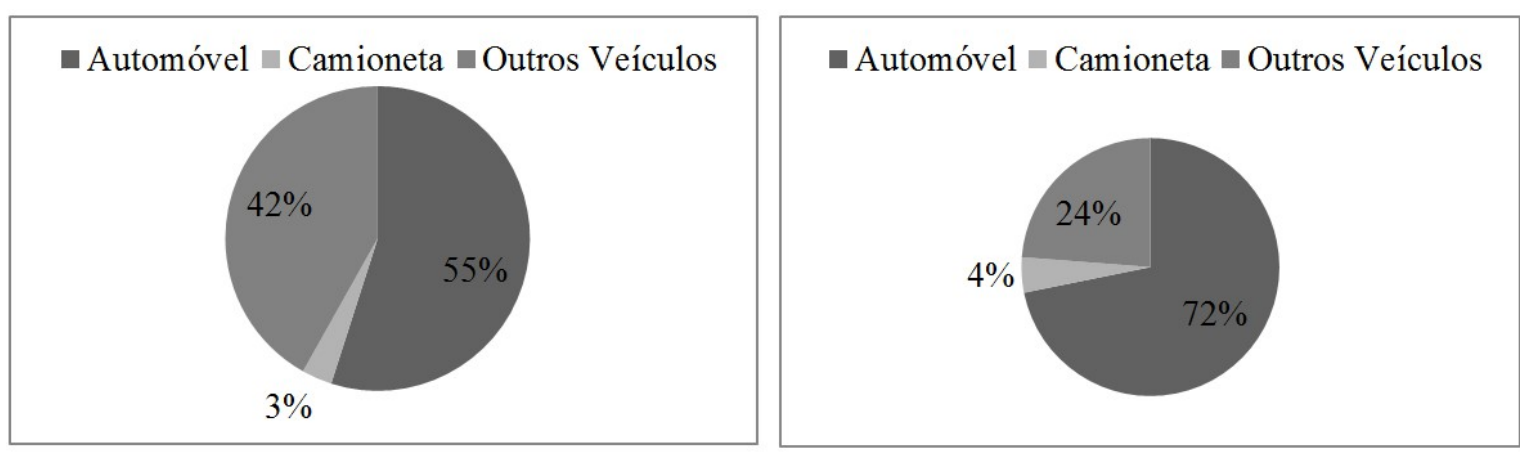

Figura 2.5 Percentual de automóveis e camionetas do total de veículos (a) Brasil e (b) DF Fonte: adaptado de DENATRAN (2015) 
Dessa maneira, percebe-se que a categoria de veículos que foi considerada nesta pesquisa é representativa em relação ao total existente, em nível nacional e regional. Ressalta-se, porém, que esses valores não consideram apenas os veículos em fim de vida útil, mas todos os cadastrados no DENATRAN.

\subsubsection{Fim de Vida Útil do Veículo Leve}

Os veículos podem atingir o estágio de fim de vida útil prematura ou naturalmente. Os veículos prematuros chegaram ao fim de vida útil antes de sua vida média, seja por incêndio, inundação, vandalismo ou danos por acidentes graves. Já os veículos que chegam ao fim de vida útil, naturalmente atingiram o tempo de duração médio esperado para a sua circulação (GO et al., 2011).

Não há uma definição fixa sobre a idade média para vida útil de um veículo, entretanto, como ela também define as possibilidades de reaproveitamento de um veículo, pois reflete a mistura de materiais e os diferentes critérios de design próprios das tecnologias disponíveis no momento da sua fabricação, é importante discutí-la (GERRARD; KANDLIKAR, 2007).

Gomes (2001) define o fim da vida útil com mais de 10 anos de fabricação. Ahmed et al., (2014) também consideram como potenciais veículos em fim de vida aqueles com essa idade. Próximo disso, o resultado de uma pesquisa, compartilhada pelo Malaysian Institute of Road Safety Research, mostra que os veículos com mais de 12 anos são inseguros, incertos e podem provocar defeitos (RAHIM, 2013 apud AHMED et al., 2014).

Medina e Gomes (2002) ao dizerem que um projeto de automóvel desenvolve-se em um horizonte de 10 a 15 anos, direcionam ao entendimento de que a tecnologia muda nesse período e pode ficar ultrapassada. Complementarmente, coloca-se que as montadoras esperam que os veículos durem por até 15 anos, considerando como veículos em fim de vida os que permanecem em circulação por mais tempo (AZMI et al., 2013).

Inghels et al. (2016), bem como Go et al. (2011), estabelecem uma idade média entre 12 e 15 anos, dado que depois disso deixam de ser viáveis. Harraz e Galal (2011) complementam ao dizerem que o tempo de vida útil de um veículo na União Europeia é estimado entre 10 e 14 anos, mas que este dado pode até dobrar quando para países em desenvolvimento. 
A variação existente sobre o entendimento da idade estipulada para o fim de vida útil fica clara na Tabela 2.1, que faz uma comparação entre países apresentados por Azmi et al. (2013). Em Taiwan e na Malásia fica estabelecido 10 anos; na China pode ser 10 anos ou 500 mil quilômetros, a depender do que ocorrer primeiro; no Japão o tempo pode ser a partir de 3 anos, a ser confirmado em inspeções de avaliação bianuais; e a idade não é especificada na Coreia e no Canada. Inghels et al. (2016) ainda acrescetam que a vida útil dos veículos leves variam em torno de 13 anos na Irlanda e de 22 anos na Finlândia.

Tabela 2.1 Comparação da idade dos veículos em fim de vida útil nos países

\begin{tabular}{c|c|c|c|c|c|c}
\hline & Taiwan & China & Coreia & Japão & Canada & Malásia \\
\cline { 2 - 7 } & Idade do Veículos \\
em Fim de Vida Útil & 10 anos & $\begin{array}{c}10 \text { anos ou } \\
500.000 \mathrm{~km}\end{array}$ & $\begin{array}{c}\text { Sem } \\
\text { especificação }\end{array}$ & $\begin{array}{c}\text { Mínimo de } 3 \\
\text { anos, com } \\
\text { inspeções } \\
\text { bianuais }\end{array}$ & $\begin{array}{c}\text { Sem } \\
\text { especificação }\end{array}$ & 10 anos \\
\hline
\end{tabular}

Fonte: Azmi et al. (2013)

No Brasil, Mildemberger et al. (2015) sugerem a idade de 10 anos de utilizadação para o fim de vida de um veículo no estado do Paraná. A Federação Nacional da Distribuição de Veículos Automotores (FENABRAVE) participou da elaboração de um programa de renovação da frota com o Ministério do Desenvolvimento da Indústria e do Comércio Exterior (MDIC) cujo foco era retirar de circulação os veículos leves com mais 15 anos (GONTIJO, 2016). Já a empresa Gerdau, em parceria com o DETRAN-RS, tritura veículos com mais de 20 anos depositados nos pátios do órgão executivo de trânsito, pois os considera veículos em fim de vida útil.

\subsubsection{Impacto dos Veículos em Fim de Vida Útil}

Dentre os impactos causados pelos veículos em fim de vida útil, pode-se citar a ocupação do espaço urbano, pois muitos deles são abandonados em locais indevidos ou nos quais poderia haver jardins, praças, circulação de veículos e pessoas, o que traz prejuízos para a mobilidade urbana e para a fluidez no trânsito (MILDEMBERGER et al., 2015).

Além disso, outro problema refere-se à emissão de poluentes pelos veículos em fim de vida útil, que muitas vezes não realizaram as manutenções necessárias e que, por conta disso, emitem mais gases poluentes na atmosfera. Ademais, a partir deles pode ocorrer vazamento de substâncias tóxicas que podem contaminar a atmosfera, o solo, a água superficial de rios, lagos e lagoas, bem como os lençóis freáticos. A falta de manutenções também faz com que esses veículos se tornem mais propensos a acidentes de trânsito 
devido ao desgaste natural de suas peças ou pela falta de peças de reposição (MILDEMBERGER et al., 2015).

O veículo em final de vida representa em média uma tonelada de resíduos - metais, tecidos, plásticos, óleos minerais e sintéticos, líquidos derivados de baterias e do sistema de arrefecimento, entre outros (GHK, 2016). Entre esses resíduos encontram-se alguns que são perigosos e precisam ser ambientalmente tratados, pois podem causar problemas de saúde na população e desequilíbrios ao meio ambiente, por serem radioativos, corrosivos, tóxicos e/ou explosivos (MONTEIRO et al., 2001).

Quando os veículos não recebem tratamento adequado, podem acumular água e podem se tornar criadouros de mosquitos vetores para transmitir vírus causadores de doenças (MILDEMBERGER et al., 2015). Esses veículos também podem servir de abrigo para animais tais como cobras e aranhas bem como para ratos, baratas e insetos em geral que devido à modificação de seus habitats naturais invadem as cidades a procura de alimentos, tornando-se assim um verdadeiro perigo para a população (RAMALHO, 2006).

Outro fator preocupante decorre da redução da possibilidade de reaproveitamento das peças, pois, com o passar dos anos, as partes metálicas podem acabar se oxidando e as partes plásticas podem sofrer deformações devido ao calor e à exposição ao sol bem como perder a sua cor natural e tornarem-se, assim, não reutilizáveis.

Por fim, um impacto gerado pelo mercado de veículos em geral, é a criminalidade com relação ao mercado de peças usadas. Com o controle e a fiscalização das empresas de reaproveitamento de veículos, espera-se reduzir essa externalidade negativa, pois havendo um comércio legal dessas mercadorias, dificilmente as pessoas procuram peças de forma ilegal e clandestina (PEREIRA FILHO, 2016). Isso é o que se tem observado em locais que adotaram um sistema estruturado de reaproveitamento de veículos. 


\section{PANORAMA DO REAPROVEITAMENTO DE VEÍCULOS LEVES EM FIM DE VIDA ÚTIL}

Desde a década de 1990, com o início da atenção para o problema da logística reversa de veículos em fim de vida útil, legislações foram aprovadas no sentido de motivar as empresas de manufatura a produzirem considerando as questões do ciclo de vida dos produtos, bem como do reaproveitamento na etapa de fim de vida (CRUZ-RIVERA, 2008; HARRAZ; GALAL, 2011).

Desde então, a maioria dos aprimoramentos nos modelos de reaproveitamento de veículos leves em fim de vida tem sido conduzida pelos países mais evoluídos nesse mercado, os que já possuem anos de experiência (CRUZ-RIVERA; ERTEL, 2009). Por outro lado, Gan e He (2014) explicam que, diante do cenário atual, as medidas para reciclagem de veículos em fim de vida útil não devem ser apenas para eles, mas também para os que se encontram ainda em estágio inicial ou em desenvolvimento.

Nesse sentido, esse capítulo tem como objetivo apresentar um panorama do reaproveitamento de veículos leves em fim de vida útil desde as boas práticas internacionais e nacionais, que mostram o direcionamento da evolução do setor, experimentada e aprimorada ao longo dos anos; até a restrita e incipiente realidade observada no mercado existente no Distrito Federal.

Assim, são ressaltadas as dificuldades, limitações e condições enfrentadas pelos empresários do contexto de estudo, à luz das experiências mais avançadas, com intuito de, no capítulo seguinte, cumprir o desafio de propor ações que atendam à legislação brasileira, melhorem o desempenho do processo de reaproveitamento de veículos leves em fim de vida útil no que diz respeito aos impactos ambientais, considerando os poucos recursos disponíveis nas empresas do Distrito Federal.

Inicialmente são discutidos os aspectos legais do reaproveitamento de veículos, com enfoque para a recente legislação brasileira. Em seguida, é exposta a formação tradicional da cadeia de reaproveitamento de veículos e, logo após, as melhores práticas observadas nos centros de reaproveitamento internacionais e nacionais são explicitadas. Por fim, é apresentado o diagnóstico com as empresas atuantes no Distrito Federal, bem como a discussão sobre a tendência da demanda para esse tipo de atividade na localidade. 


\subsection{ASPECTOS LEGAIS DO REAPROVEITAMENTO DE VEÍCULOS}

As regulamentações pioneiras para aspectos relativos à implementação de processos sistêmicos para reaproveitamento de veículos são às da União Européia, dos Estados Unidos e do Japão. Nessas regiões estão localizadas as maiores frotas de veículos do mundo e, consequentemente, houve grande urgência por processos desse tipo (CASTRO; SOUZA; BOLOVENTA 2012).

A Diretiva Europeia sobre veículos em fim de vida (Diretiva 2000/53/EC) mudou fundamentalmente o modelo do sistema europeu de reaproveitamento de veículos, que era exlusivamente orientada ao lucro (SIMIC; DIMITRIJEVIC, 2012). As montadoras passaram a ser responsabilizadas pelo ciclo de vida dos veículos e houve um incentivo ao desenvolvimento de novos materiais e a processos de menor impacto ambiental.

Aprovada, os países membros passaram a ter como meta a reutilização e a reciclagem de 80\% do peso do veículo até o ano de 2006 e de 90\% para 2015 (HARRAZ; GALAL, 2011). Em seguida, vários deles fizeram recomendações adicionais às montadoras de veículos: redução da utilização de materias pesados, revisão dos projetos veiculares, incentivo à inserção de materiais reciclados (CASTRO; SOUZA; BOLOVENTA 2012).

Nos Estados Unidos, por outro lado, não há legislação nacional que trata sobre reaproveitamento de veículos, mas diversas leis estaduais e municipais abordam o tema. Existem regulamentações que estabelecem metas de reciclagem, tratam de aspectos referentes à gestão dos resíduos perigosos e, também, que incentivam a troca de veículos antigos por veículos novos menos poluentes com subsídios governamentais (CASTRO; SOUZA; BOLOVENTA 2012).

A lei que regulamenta a reciclagem de veículos no Japão foi promulgada em 2005 e prevê a mesma meta estabelecida pela Comunidade Européia para 2015. Nela também está previsto que, ao comprar um veículo novo, o proprietário é obrigado a pagar uma taxa previamente destinada à reciclagem de três itens específicos: resíduos provenientes da fragmentação de veículos, airbags e gases contendo clorofluorcarbonetos (CASTRO; SOUZA; BOLOVENTA 2012). 
Percebe-se, portanto, que esses países já possuem mais de uma década de histórico relacionado com o reaproveitamento regulado de veículos leves em fim de vida útil. Experiências bem e mal sucedidas já foram verificadas e evoluções concretizadas. Tais ocorrências acabam por formar um modelo capaz de obter resultados positivos, mesmo que, em algumas situações pontuais, ele ainda não seja totalmente empregado.

Por outro lado, no Brasil, a primeira legislação federal específica para reaproveitamento de veículos leves em fim de vida útil foi a Lei 12.977 de 20 de maio de 2014. Anterior a ela, a Política Nacional dos Resíduos Sólidos (Lei 12.305/ 2010 e Decreto 7.404/ 2010) instituiu diretrizes relativas à gestão integrada de resíduos sólidos, incluindo baterias, pneus, equipamentos eletrônicos, óleos, materiais relacionados a veículos.

Ademais, as Resoluções CONAMA 362/ 2005, 401/ 2008, 416/ 2009 e a Instrução Normativa IBAMA 13/ 2012 abordaram a maneira como deve ocorrer o recolhimento, o tratamento, o gerenciamento e a destinação final de determinados desses materiais. No entanto, exclusivamente sobre veículos em fim de vida, anterior à Lei 12.977/ 2014 e que tenha realmente sido implementada, apenas a Lei 15. 276 de 02 de janeiro de 2014 do estado de São Paulo, publicada com meses de antecedência.

Essa breve retrospectiva sinaliza o recente envolvimento do Brasil com o gerenciamento do ciclo de vida dos produtos e, principalmente, com os veículos em fim de vida útil. De toda forma, observa-se que algumas das exigências impostas pelas legislações mais maduras foram levadas em consideração:

- necessidade de registro oficial das empresas participantes do sistema de reaproveitamento de veículos;

- exigência da emissão de documento de confirmação da baixa do registro do veículo para início da desmontagem;

- integração das informações sobre os fluxos de movimentação e de transformação de materiais através de uma base de dados para rastreabilidade;

- divulgação das informações das empresas registradas em ambiente público de forma a incentivar a fiscalização por terceiros.

A Resolução CONTRAN 611/ 2016 regulamenta a Lei 12.977/ 2014 e conceitua desmontagem, destinação, reposição, reciclagem e recuperação de peças, além de 
estabelecer exigências adicionais para a atividade de desmontagem. Ela revoga a Resolução CONTRAN 530/ 2015 em virtude de a primeira suprimir aspectos importantes dos centros de desmontagem, fato que já mostra um aprimoramento, mesmo que pequeno.

De toda forma, as pesquisas de campo realizadas mostram que ainda existe uma preocupação por parte do mercado em relação à Lei 12.977/ 2014 e à Resolução CONTRAN 611/ 2016. Esse fato ocorre devido ao fato de elas estabelecerem prazos para a realização das atividades, mas não determinarem como devem ser realizadas, provocando uma insegurança sobre como implementar mudanças que atendam às exigências.

A Figura 3.1 apresenta os prazos para a realização das principais atividades do centro de reaproveitamento. Para inserção de dados do veículo no sistema e para pedido do Certificado de Baixa do Veículo há um prazo de 5 dias a contar da chegada do veículo. A retirada da possibilidade de circulação do veículo deve ser feita até 10 dias após a obtenção do Certificado de Baixa. A comunicação do fim da desmontagem do veículo deve ocorrer em 3 dias, o registro das peças retiradas do veículo em 5 dias e a saída das peças não reutilizáveis deve acontecer em 20 dias após o encerramento da desmontagem.

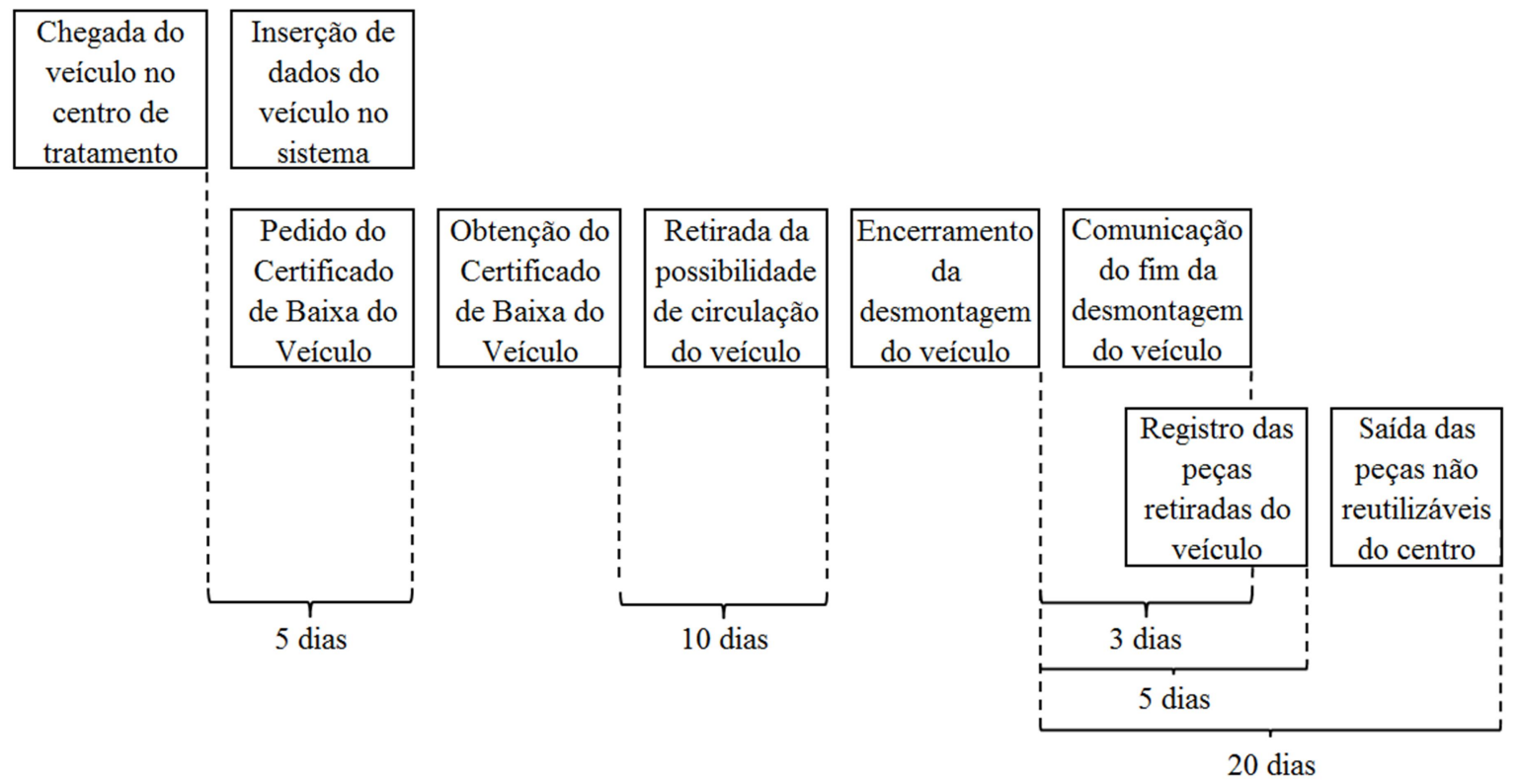

Figura 3.1Prazos para realização das principais atividades de acordo com a regulamentação Fonte: Lei 12.977/ 2014 e Resolução CONTRAN 611/ 2016

Ademais, existem outras regulamentações que influenciam as atividades de um centro de reaproveitamento de veículos em fim de vida e que merecem ser destacadas: Lei 9.503/ 1997 (Código de Trânsito Brasileiro); Lei 8.722/ 1993, Decreto 1.305/ 1994, Resolução 
CONTRAN 11/ 1998, Resolução CONTRAN 113/2000 e Resolução CONTRAN 179/ 2005 (Baixa de Registro de Veículos); e Resolução Conselho Nacional de Seguros Privados (CNSP) 336/ 2016 (Seguro Popular de Automóvel).

Das regulamentações citadas, cabe ressaltar a última, que dispõe sobre as regras e os critérios para operação do Seguro Auto Popular, capaz de permitir a utilização, por seguradoras, de peças usadas oriundas de empresas de desmontagem registradas pelos órgãos executivos de trânsito dos estados ou Distrito Federal.

Nesse contexto, alguns estados brasileiros também publicaram leis, decretos e portarias complementares à regulamentação federal. São eles: São Paulo (Lei 15.276/ 2014, Decreto 60.150/ 2014, Portaria DETRAN-SP 510/ 2015); Espírito Santo (Lei 10.031/ 2013); Paraná (Portaria DETRANP-PR 165/ 2016); Santa Catarina (Portaria DETRAN-SC 622/ 2016); Rio Grande do Sul (Lei 12.745/ 2007, Decreto 51.990/ 2014, Portaria DETRAN-RS 184/ 2015); Mato Grosso do Sul (Portaria DETRAN-MS 25/ 2015); Tocantins (Portaria DETRAN-TO 859/ 2015) e Goiás (Portaria DETRAN-GO 345/ 2015).

Alguns dos instrumentos normativos citados são, inclusive, anteriores à Lei 12.977/ 2014, entretanto, não foram realmente colocados em prática e, por isso, não foram obtidos resultados. Outros estados como os de Minas Gerais, do Rio Grande do Norte, de Alagoas, de Pernambuco e o Distrito Federal não possuem normas publicadas, mas já iniciaram a discussão entre as partes interessadas no assunto. No que diz respeito ao conteúdo das normas, elas são genéricas, similares e com pequenos pontos de especificidades relacionadas às características de cada um dos estados.

\subsection{CADEIA DE REAPROVEITAMENTO DE VEÍCULOS LEVES}

Os veículos advêm da cadeia automobilística que, de uma forma geral, obtém matériasprimas adequadas à manufatura e montagem desse tipo de produto, para posterior comércio no mercado e, consequentemente, uso por parte dos consumidores. Ahmed et al. (2014) ilustram, como mostra a Figura 3.2, o relacionamento entre essas operações e detalham com maior enfoque o desdobramento posterior - o da cadeia de reaproveitamento de veículos em fim de vida útil. 


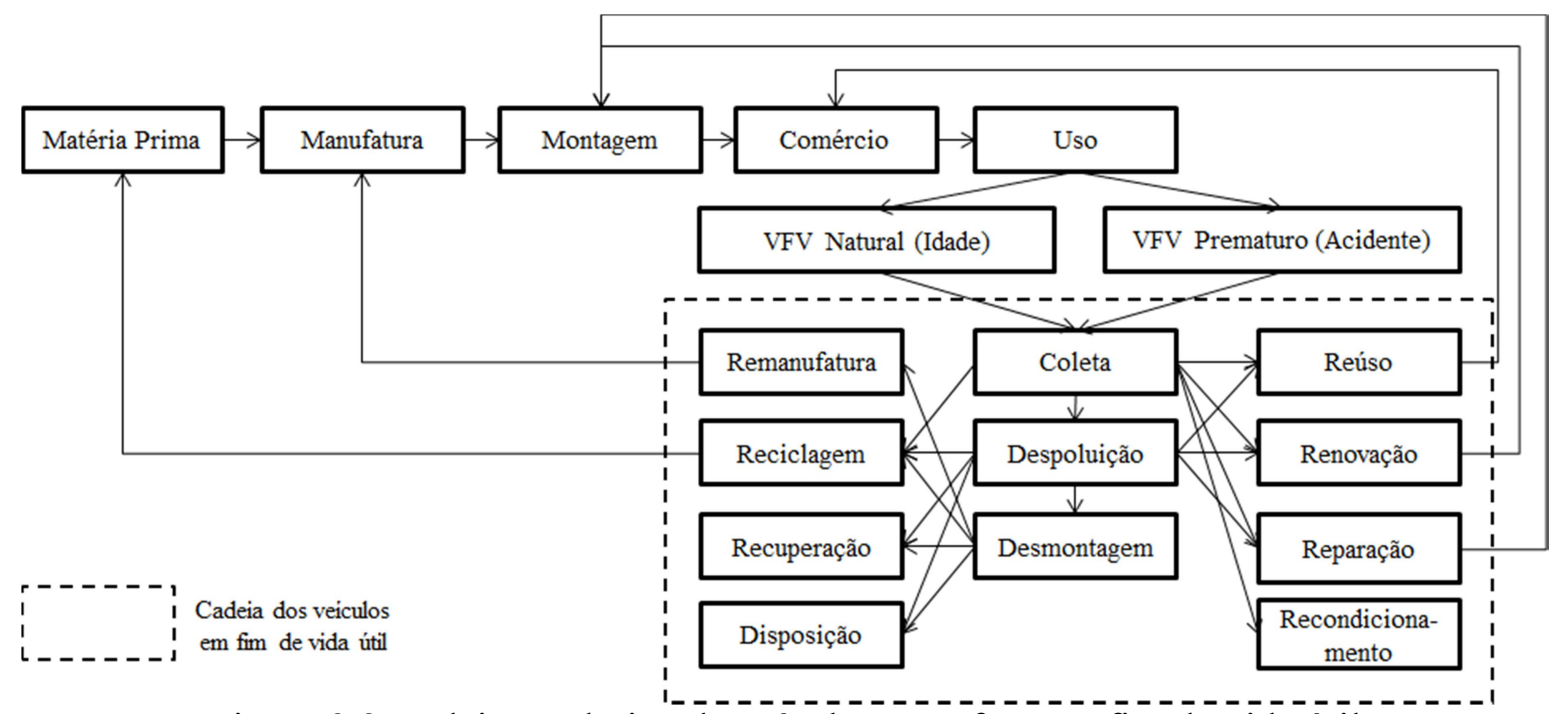

Figura 3.2 Cadeia produtiva de veículos com foco no fím de vida útil

Fonte: adaptado de Ahmed et al. (2014)

Tradicionalmente, a cadeia de reaproveitamento dos veículos em fim de vida inicia na coleta dos veículos com idade avançada ou dos que sofreram acidentes e perderam capacidade de circulação prematuramente (AHMED et al., 2014).

Eles podem ser entregues às unidades de coleta pelos últimos proprietários ou podem ser recolhidos do local no qual se encontram por meio de um serviço de retirada disponibilizado pela própria unidade de coleta. Essas condições e facilidades para coleta dos veículos devem ser planejadas porque elas podem incentivar ou não que os veículos em fim de vida útil seja encaminhados às unidades de coleta (CRUZ-RIVERA, 2008).

A Diretiva 2000/ 53/ CE, por exemplo, orienta que os Estados-Membros devem tomar as medidas necessárias para garantir que o último proprietário possa entregar o veículo em fim de vida útil numa unidade de coleta autorizada, sem quaisquer encargos, em consequência de o veículo ter um valor negativo ou nulo.

Por outro lado, no caso da Renova Ecopeças em São Paulo, a parceria feita com a seguradora Porto Seguros a mantém abastecida de veículos em fim de vida útil continuamente, tendo em vista o alto número de veículos sinistrados classificados como irrecuperáveis ou de grande monta que são coletados por essa seguradora e entregues na sua planta industrial.

Independentemente da forma de coleta do veículo, Sohn e Park (2014) sugerem que haja o registro das principais informações do veículo, a elaboração de uma lista de peças reutilizáveis a partir de uma inspeção preliminar do veículo orientada por checklist e o 
planejamento da desmontagem. Além disso, os autores exigem que haja a emissão de um Certificado de Destruição para cancelamento do registro do veículo. Cruz-Rivera (2008) também orienta que esse documento seja dado ao último proprietário no recebimento pelas unidades, para organização dos processos de reaproveitamento desses veículos.

Pode ser que os veículos sejam recebidos nas unidades de coleta e encaminhados diretamente para os locais de desmontagem (MERKISZ-GURANOWSKA, 2011). Entretanto, comumente elas próprias assumem as atividades de despoluição e desmontagem, passando a ser chamadas de centros de reaproveitamento (CRUZ-RIVERA; ERTEL, 2009; MANSOUR et al., 2010). Essa dissertação considerou esse tipo de unidade industrial na proposição do seu modelo.

A fase de despoluição é a etapa mais crítica no tratamento dos veículos em fim de vida útil, (BERZI et al., 2013). A sua importância não pode ser subestimada porque um desempenho abaixo do esperado nessa etapa pode produzir impactos negativos nas próximas atividades da cadeia de reaproveitamento de veículos (CRUZ-RIVERA, 2008). Sohn e Park (2014) consideram a etapa inclusive como um pré-tratamento para desmontagem.

$\mathrm{Na}$ desmontagem, todos os elementos do veículo são retirados - os passíveis de reutilização, os direcionados a outras estratégias de gerenciamento, os perigosos e os resíduos (MERKISZ-GURANOWSKA, 2011). Go et al. (2012) colocam a desmontagem como um dos fatores determinantes para o reaproveitamento dos veículos em fim de vida útil e, por isso, uma atividade importante e complexa dentro do seu ciclo de vida.

Em seguida, as operações de despoluição e desmontagem direcionam às estratégias de gerenciamento do veículo em fim de vida: reúso, renovação, reparação, recondicionamento, remanufatura, reciclagem, recuperação e disposição final. Opções que não são excludentes e podem ser tratadas como complementares (AHMED et al., 2014).

\subsection{ESTRATÉGIAS DE GERENCIAMENTO DE VEÍCULOS EM FIM DE VIDA ÚTIL}

De acordo com a Diretiva 2000/ 53/ CE, o reúso é a operação que direciona os componentes do veículo em fim de vida útil para que sejam utilizados no mesmo fim para que foram concebidos, como no caso de serem reutilizados durante a manutenção ou o reparo de veículos (INGHELS et al., 2016). 
Por outro lado, Ahmed et al. (2014) e Harraz e Galal (2011) dizem que pode ser com a mesma finalidade ou em outras aplicações. Para Go et al. (2012) essa estratégia está ganhando importância pelo impacto positivo que trás ao meio ambiente. Ahmed et al. (2014) concordam, pois colocam que o reúso é uma tentativa de reduzir o consumo de nova matéria-prima para produzir os produtos ou seus componentes.

Com intuito de desenvolver e incentivar essa estratégia de reaproveitamento, Cruz-Rivera (2008) sugere que o seu país - México -, a fim de divulgar o mercado de peças reaproveitadas, crie um inventário nacional de peças de reposição usadas e remanufaturadas à venda e o divulgue eletronicamente para que um grande volume de potenciais compradores tenha acesso a esse mercado. $\mathrm{O}$ interessante do sistema de informação disponibilizado pelo DETRAN-SP é que ele já engloba essa funcionalidade a partir de uma ferramenta de busca por montadora, modelo e peça.

Se a peça não pode ser reutilizada diretamente, pode ser que ela exija algum trabalho adicional para tornar o reúso possível (GO et al., 2011). A renovação é o processo de aprimorar as condições do produto através da troca, alteração ou da limpeza de partes (HARRAZ; GALAL, 2011).

A reparação é a simples correção de um defeito específico no produto. Geralmente, a qualidade do produto reparado é inferior à daqueles recondicionados ou remanufaturados. Quando reparados, os produtos têm garantias restritas ao componente modificado (AHMED et al., 2014).

O recondicionamento exige mais trabalho especializado que o aplicado na reparação, porém menos que o necessário à remanufatura. Isso se deve porque normalmente requer a reconstituição dos componentes principais de uma condição de funcionamento, o que proporciona um nível de qualidade que normalmente é inferior à do modelo original (AHMED et al., 2014).

A remanufatura exige o desmantelamento total do produto e a restauração com substituição de componentes. Nesse caso, são dadas garantias iguais às dos novos produtos equivalentes (AHMED et al., 2014). Sendo assim, a remanufatura significa que o produto é reprocessado ou melhorado em um processo industrial. Ela tem como objetivo extender o tempo de uso de um produto, direcionando-o a uma segunda vida útil (GO et al., 2011). 
Para a Diretiva 2000/ 53/ CE, a reciclagem é o reprocessamento, no âmbito de um processo de produção, dos materiais residuais para o fim original ou para outros fins. É um processo que exige altos investimentos e que, em algumas localidades, ainda continua sem viabilidade econômica em virtude do baixo valor de alguns produtos no mercado (plástico, vidro, têxtil) (INGHELS et al., 2016).

Além disso, Tasala Gradin, Luttropp e Björklund (2013) colocam que os processos atuais de reciclagem para veículos em fim de vida útil foram estabelecidos há cinquenta anos, quando essa indústria iniciou e que as tecnologias atualmente em uso permanecem as mesmas. Assim, Ahmed et al. (2014) colocam que ela deve ser utilizada quando as outras estratégias de reaproveitamento não são possíveis.

A recuperação é o uso de resíduos para propósitos úteis, como recuperação energética ou pavimentação de estradas (GO et al., 2011). Existem diferentes métodos: incineração, pirólise, gaseificação, hidrólise, liquefação, hidrogenação (ZHAO; CHEN, 2011). A incineração é o principal método de recuperação, pelo qual os resíduos são submetidos à combustão até a completa conversão em pequenos resíduos e produtos gasosos (AHMED et al., 2014).

Os plásticos automobilísticos normalmente não são puros, mas compostos de outros materiais para alcance de propriedades específicas, o que dificulta a sua separação e reciclagem. Por isso, algumas empresas fazem o reaproveitamento deles através da pirólise ou da incineração, mesmo com custo elevado e possibilidade de poluição do ar (ZHAO; CHEN, 2011).

A última estratégia que pode ser utilizada para o gerenciamento de um material é a disposição final (aterros sanitários) (AHMED et al., 2014; MERKISZ-GURANOWSKA, 2011; YI; PARK, 2015). A disposição final de materiais em lixões não é considerada uma estratégia de gerenciamento adequada, tendo em vista o impacto negativo que provoca no meio ambiente.

A fim de estabelecer a priorização entre as estratégias de gerenciamento, Gerrard e Kandlikar (2007) as ilustram em uma pirâmide hierarquizada sob dois aspectos - eficiência do material e eficiência energética, como mostra a Figura 3.3. Nela, fica claro que o reúso é a abordagem preferencial, enquanto a disposição final deve ser selecionada para a menor 
quantidade possível de produtos. No nível da remanufatura, podem ser alocados renovação, reparação e recondicionamento, visto que são complementares com pequenas variações.

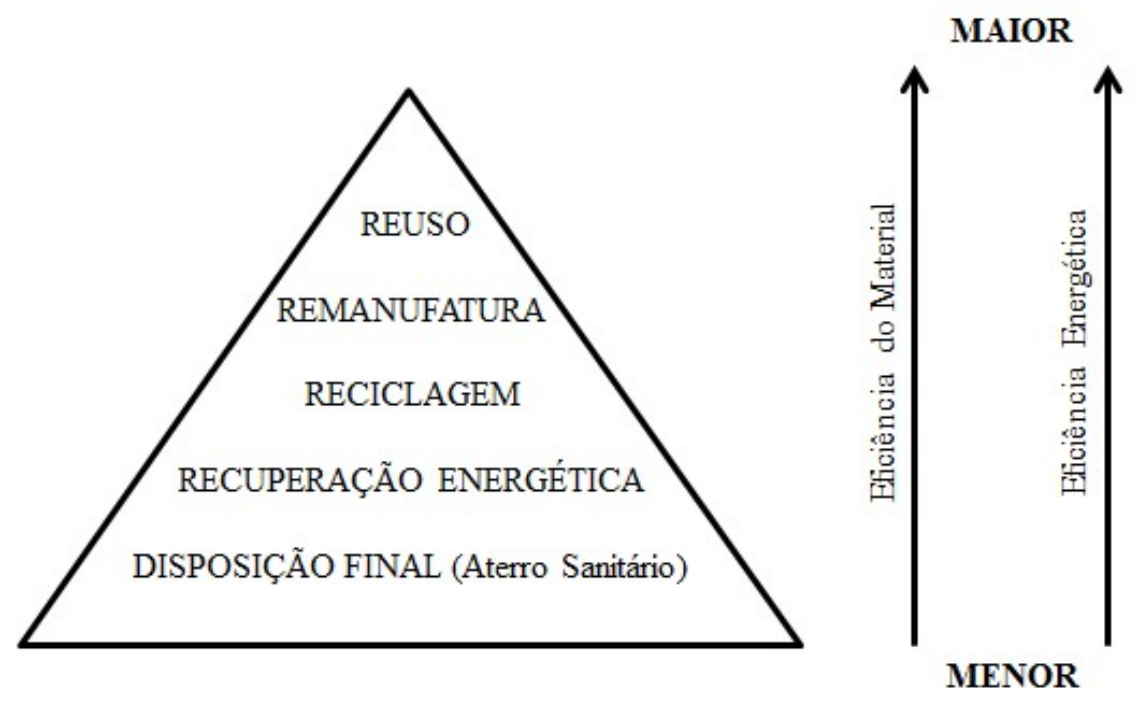

Figura 3.3 Hierarquia das estratégias de reaproveitamento de veículos em fim de vida Fonte: Gerrard e Kandlikar (2007)

Em virtude das diferentes estratégias de gerenciamento a depender da peça e/ ou da parte do veículo, Sohn e Park (2014) propõem uma estação de reaproveitamento, na qual deve ocorrer a avaliação da qualidade dos elementos, classificação, codificação e registro dos procedimentos que devem ser tomados a seguir.

A definição da estratégia de gerenciamento para cada peça do veículo depende da sua condição de recuperabilidade específica. Mathieux, Froelich e Moszkowicz (2008) definem a recuperabilidade como a capacidade de recuperação dos seus componentes e materiais constitutivos, seja para reúso, direta ou indiretamente, para reciclagem ou para recuperação.

Ademais, nesse momento, também devem ser consideradas as situações econômicas e geográficas da localidade na qual se encontra o centro de reaproveitamento (MANSOUR et al., 2010). Em regiões nas quais a cadeia de reaproveitamento é fortalecida, ocorre a participação de diferentes atores especializados nas diferentes estratégias de gerenciamento. Ao contrário, em locais com mercado iniciante, pode haver menos possibilidades para as estratégias de gerenciamento, como é o caso do Distrito Federal.

Assim, pode acontecer de não haver disponibilidade de empresa para implementação da estratégia ótima próximo à unidade de desmontagem. Nesse caso, a necessidade de 
transporte pode inviabilizar o tratamento e exigir que outra opção, menos eficiente, precise ser selecionada.

\subsection{CENTROS DE REAPROVEITAMENTO DE VEÍCULOS LEVES}

Como visto anteriormente (seções 3.2 e 3.3), os centros de reaproveitamento, além de realizarem as etapas de coleta, despoluição e desmontagem, ainda direcionam os materiais para as diferentes estratégias de gerenciamento. Sendo assim, possuem um papel central na cadeia de reaproveitamento e, por isso, é importante que as suas operações sejam realizadas de forma controlada (HARRAZ; GALAL, 2011).

\subsubsection{Estruturação das Atividades}

Na Europa, para garantia das metas impostas pela Diretiva 2000/53/CE e da viabilidade econômica dos negócios de desmontagem de veículos em fim de vida útil, as operações de desmontagem requerem ferramentas de larga escala, técnicas sofisticadas e, consequentemente, modelos estruturados (ENE; ÖZTÜRK, 2015; GO et al., 2011). No Japão, país que possui modelo de reaproveitamento de veículos de sucesso, as atividades também são organizadas e automatizadas (ZHAO; CHEN, 2011).

Com intuito de facilitar a estruturação das atividades, duas iniciativas merecem ser destacadas por promoverem a integração e a simplificação das atividades de reaproveitamento. A primeira delas partiu de algumas montadoras (Audi, BMW, Daimler, Ford, Opel, Porsche, VW e Volvo), que desenvolveram o Internacional Material Data System (IMDS), sistema que apresenta os materiais existentes nos componentes dos veículos e permite a comparação de cada componente com as listas de materiais proibidos (BERZI et al., 2013).

Também, para disseminação do conhecimento sobre como realizar a desmontagem corretamente, o Internacional Dismantling Information System (IDIS) proporciona informação para identificação dos poluentes e dos produtos perigosos nos veículos em fim de vida útil, bem como, da melhor forma de remover as partes não metálicas do veículo. A documentação é preparada para veículos de 1985 até os dias atuais (BERZI et al., 2013).

Dessa maneira, os sistemas - IMDS e IDIS - contribuem com a disseminação das melhores práticas para despoluição e desmontagem. Entretanto, eles abordam os veículos europeus e, por isso, podem não ser compatíveis em outros países do mundo. De toda 
forma, Cruz-Rivera (2008) enfatiza que a cooperação entre as montadoras e os centros de reaproveitamento é essencial tendo em vista a diversidade de veículos em circulação. Sem essa cooperação, dificilmente os centros de reaproveitamento conseguem obter o conhecimento técnico para realizarem adequadamente a despoluição, por exemplo.

Normalmente, as regulamentações estabelecem prazos máximos para que o centro de desmontagem realize a separação dos pneus, fluídos, combustíveis, óleos, lubrificantes e baterias (YI; PARK, 2015). E, para que eles sejam cumpridos, é necessário haver uma estruturação dos passos a serem seguidos, a começar pela identificação dos fluidos que precisam ser retirados. A Tabela 3.1 mostra os materiais que devem ser removidos na despoluição segundo alguns autores.

Tabela 3.1 Relação dos materiais removidos na etapa de despoluição por autor

\begin{tabular}{|c|c|c|c|c|c|}
\hline Material/ Autores & $\begin{array}{c}\text { Diretiva } \\
2000 / 53 / \\
\mathrm{CE}\end{array}$ & $\begin{array}{c}\text { Cruz- } \\
\text { Riviera } \\
(2008)\end{array}$ & $\begin{array}{c}\text { Sohn e } \\
\text { Park } \\
(2014)\end{array}$ & $\begin{array}{c}\text { Ene e } \\
\text { Öztürk } \\
\text { (2015) }\end{array}$ & $\begin{array}{c}\text { Yi e } \\
\text { Park } \\
(\mathbf{2 0 1 5})\end{array}$ \\
\hline Pneus & & & $\mathrm{X}$ & & $\mathrm{X}$ \\
\hline Óleo do motor & $\mathrm{X}$ & $\mathrm{X}$ & $\mathrm{X}$ & $\mathrm{X}$ & $\mathrm{X}$ \\
\hline Líquido de arrefecimento do motor & $\mathrm{X}$ & $\mathrm{X}$ & & $\mathrm{X}$ & \\
\hline Combustível & $\mathrm{X}$ & $\mathrm{X}$ & $X$ & $\mathrm{X}$ & $\mathrm{X}$ \\
\hline Fluídos & & & & $\mathrm{X}$ & $\mathrm{X}$ \\
\hline Fluido de freio & & $\mathrm{X}$ & $\mathrm{X}$ & & \\
\hline Fluido do ar condicionado & $\mathrm{X}$ & & $\mathrm{X}$ & $\mathrm{X}$ & \\
\hline Fluido limpador de para-brisa & & $\mathrm{X}$ & & & \\
\hline Fluido da transmissão & $\mathrm{X}$ & $\mathrm{X}$ & & $\mathrm{X}$ & \\
\hline Fluido da direção & $\mathrm{X}$ & $\mathrm{X}$ & & $\mathrm{X}$ & \\
\hline Fluido dos eixos & & $\mathrm{X}$ & & & \\
\hline Repositórios de fluídos & $\mathrm{X}$ & & & & \\
\hline Baterias & $\mathrm{X}$ & $\mathrm{X}$ & $\mathrm{X}$ & & $\mathrm{X}$ \\
\hline Materiais explosivos e com mercúrio & $\mathrm{X}$ & & & & \\
\hline
\end{tabular}

Da Tabela 3.1, é possível perceber que há elementos majoritariamente citados - óleo do motor, líquido de arrefecimento do motor, combustível, fluido do ar condicionado, fluido de transmissão e da direção, baterias - e outros pouco comentados - fluido limpador de para-brisa, fluido dos eixos e materiais explosivos.

A diferenciação ocorre tendo em vista o grau de exigência e maturidade do sistema de reaproveitamento de veículos. Cruz Rivera (2008), por exemplo, considera em seu trabalho a implementação gradual do sistema de gerenciamento dos veículos leves em fim de vida útil que está havendo no México e estabelece metas para os diferentes graus de desenvolvimento. 
A Diretiva 2000/ 53/ CE, além da indicação colocada na Tabela 3.1, orienta que as empresas façam uso de sistemas de gestão ambiental certificados, como é o caso da ISO ISO 14.001: 2015. A experiência observada na Renova Ecopeças no estado de São Paulo acrescenta a lavagem a seco e a aspiração do veículo. A Figura 3.4 mostra a área de despoluição visitada, com enfoque para os recipientes para armazenamento dos fluidos coletados e para a delimitação dos espaços por meio de marcações no piso.
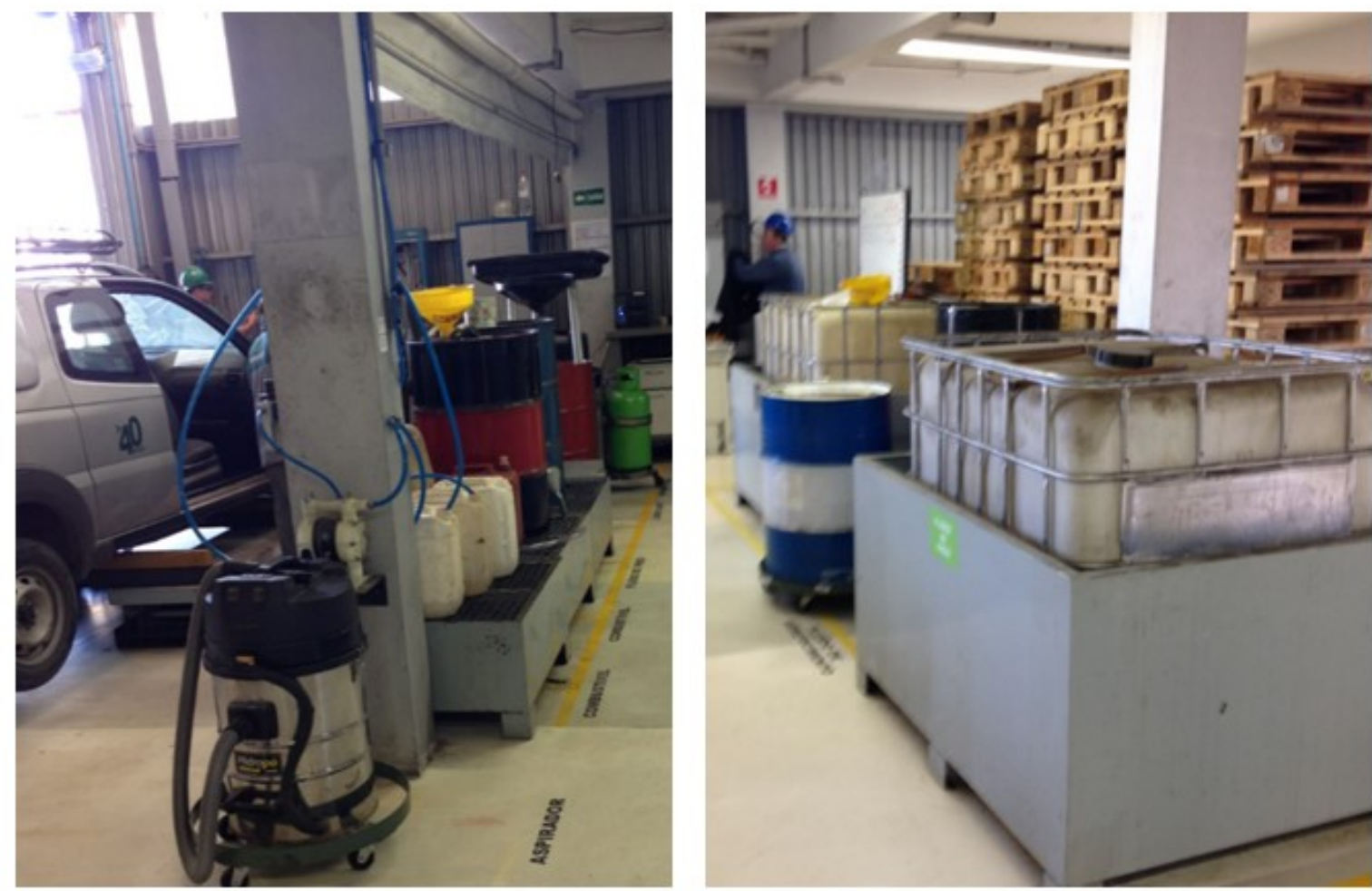

Figura 3.4 Área de despoluição de veículos na Renova Ecopeças Fonte: Renova Ecopeças

Com base em testes, Sohn e Park (2014) colocam que, para retirada dos pneus, facilita colocar o carro suspenso. Por outro lado, em pesquisa realizada com centros de reaproveitamento na Itália, Berzi et al. (2013) identificaram que os líquidos perigosos são encaminhados a centros especializados nessa etapa e ainda observaram que a retirada dos fluidos das suspensões e neutralização dos componentes pirotécnicos (airbags) é incomum.

A estruturação das atividades dos centros continua na desmontagem, que pode ser categorizada em destrutiva ou não destrutiva, de acordo com os danos que são provocados nas peças e nas partes do veículo ao longo da desmontagem. Na primeira delas, as partes do veículo são fragmentadas e quebradas, enquanto na desmontagem não destrutiva as peças são retiradas do veículo, mantendo ao máximo a sua integridade (YI; PARK, 2015). 
As empresas chinesas normalmente adotam a desmontagem destrutiva para veículos com mais de 10 anos de vida útil, em virtude de as partes desses veículos provavelmente já estarem desgatadas e dificilmente atenderem como peças de reposição para veículos de novas tecnologias (YI; PARK, 2015). Os veículos mais novos passam pela desmontagem não destrutiva para que a máxima quantidade de suas partes seja posteriormente reutilizada.

Independentemente do tipo de desmontagem, para que haja possibilidade de reaproveitamento, é necessário que ela ocorra de forma adequada. Nesse sentido, melhorias no processo de desmontagem podem ser alcançadas em dois momentos: no projeto do veículo (design for disassembly) e no planejamento da sequência das atividades da desmontagem não destrutiva (GO et al., 2012).

A sequência de desmontagem é o ordenamento das atividades de desmontagem que começa com um produto a ser desmontado e termina em uma situação onde todas as suas partes estão desconectadas (GUNGOR; GUPTA, 1997). Identificar a sequência mais adequada não é fácil tendo em vista que o número de alternativas aumenta exponencialmente com o número de partes contidas no produto a ser desmontado (GO et al., 2012).

Sohn e Park (2014) fazem uma proposta para os centros de reaproveitamento com o sequenciamento de cinco estações de trabalho: pré-estação, estação 1, estação 2, estação 3 e estação inclinada. Cada uma delas faz a desmontagem de um material específico, como mostra a Figura 3.5, mas não há detalhamento aprofundado no ordenamento das peças.
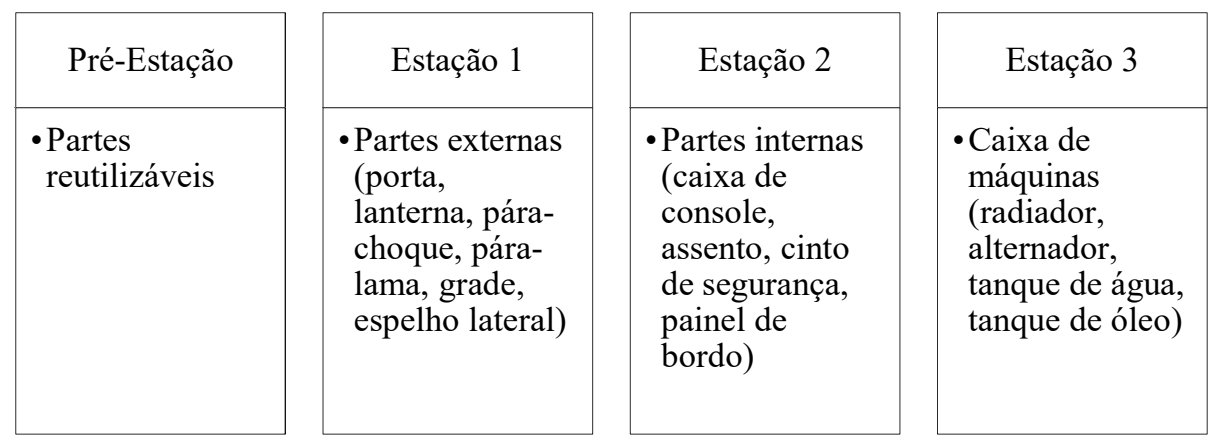

\begin{tabular}{|l|}
\hline \multicolumn{1}{|c|}{$\begin{array}{c}\text { Estação } \\
\text { Inclinada }\end{array}$} \\
\hline $\begin{array}{l}\text { Partes debaixo } \\
\text { (eixo, } \\
\text { amortecedor, } \\
\text { tanque de } \\
\text { combustível, } \\
\text { bomba, motor } \\
\text { de arranque, } \\
\text { motor) }\end{array}$ \\
\hline
\end{tabular}

Figura 3.5 Estações de trabalho para desmontagem de veículos em fím de vida Fonte: Sohn e Park (2014)

Primeiramente são desmontadas as partes identificadas como reutilizáveis na etapa de recebimento do veículo. Em seguida, as estações de trabalho 1, 2 e 3 são responsáveis por 
remover as partes externas, internas e a caixa de máquinas do veículo, nessa ordem. Por último, com o veículo deitado na estação inclinada, as partes debaixo são retiradas.

Cruz-Rivera (2008) estrutura a desmontagem em duas estações de trabalho, das quais coloca a primeira como mandatória e a segunda como opcional, tendo em vista a implementação gradual das exigências para reaproveitamento de veículos. A Tabela 3.2 mostra os elementos que devem ser desmontados em cada estação nessa proposta.

Tabela 3.2 Estações de trabalho para desmontagem de veículos em fim de vida

\begin{tabular}{l|l}
\hline Estação de trabalho & Elementos a serem desmontados \\
\hline Estação 1 (obrigatória) & $\begin{array}{l}\text { Airbags, sistema de ar-condicionado, rodas, fiação, filtros (óleo, combustível, ar), } \\
\text { conversor catalítico. }\end{array}$ \\
\hline Estação 2 (opcional) & $\begin{array}{l}\text { Radiador, arranque, gerador, transmissão, painel de instrumentos, amortecedor, } \\
\text { assentos, cintos de segurança, vidros. }\end{array}$
\end{tabular}

Fonte: adaptado de Cruz-Rivera (2008)

A desmontagem na Renova Ecopeças acontece com apoio de um procedimento operacional padrão elaborado pela própria empresa com auxílio da Porto Seguros. Ela inicia com os veículos em áreas específicas de desmontagem, como a ilustrada na Figura 3.6, e finaliza com a separação fina das peças, que costuma exigir equipamento mais específico e pessoal mais capacitado e técnico.

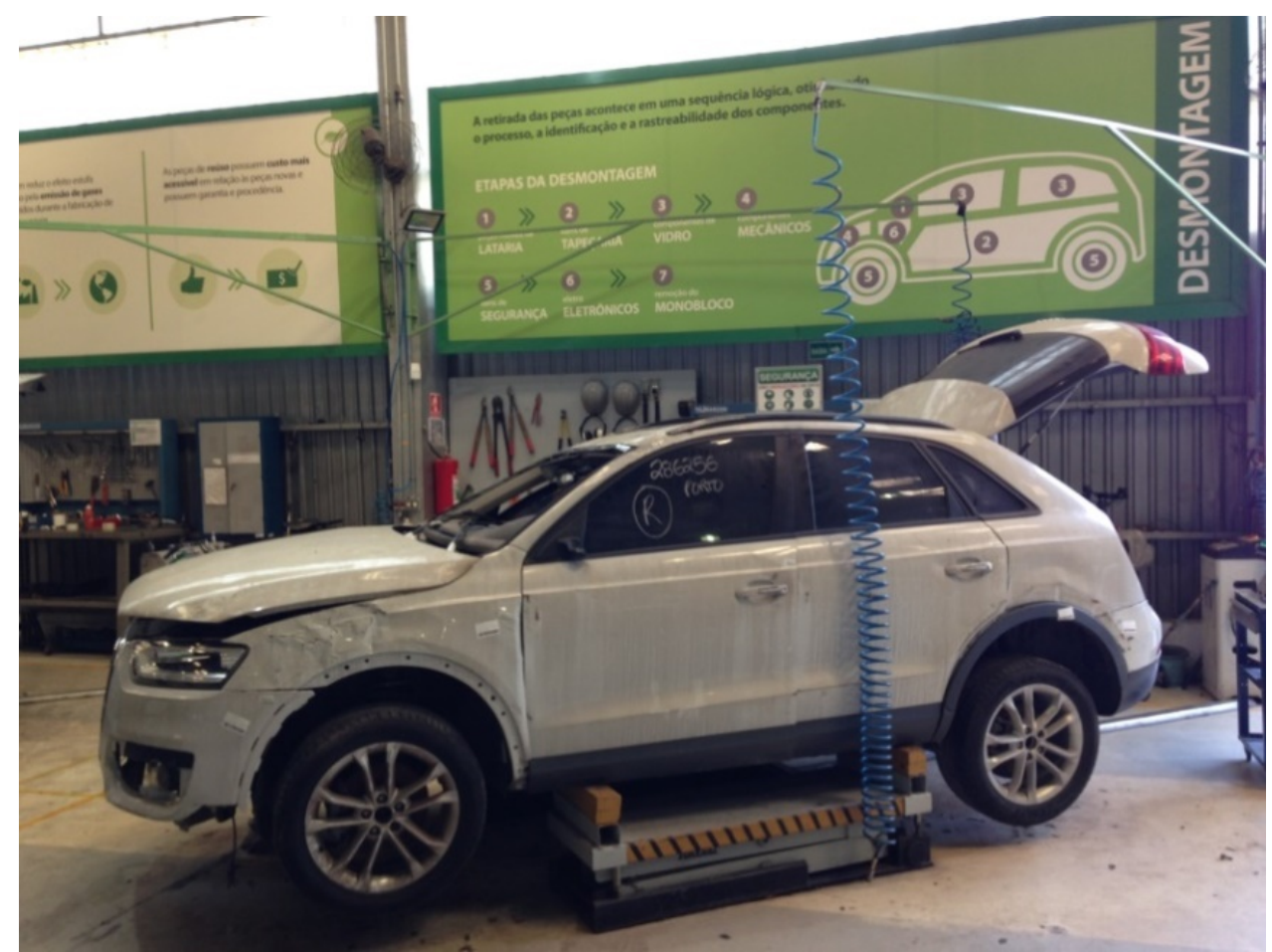

Figura 3.6 Área de desmontagem de veículos na Renova Ecopeças Fonte: Renova Ecopeças 
As partes que não são diretamente reutilizáveis são encaminhadas para a etapa de desmontagem destrutiva, que abrange a prensagem e a trituração. A prensagem é feita para que as partes que precisam ser armazenadas e transportadas possuam menor volume para reduzir espaço de estoque e reduzir custo de transporte (CRUZ-RIVERA, 2008). A Renova Ecopeças possui uma prensa própria e a utiliza para peças que não vendem ou que não podem ser vendidas por proibição jurídica.

As partes encaminhadas para a trituração têm como resultados frações de metais ferrosos (ferro e aço) e não ferrosos (alumínio, cobre, zinco, chumbo), não metais e resíduos triturados (ENE; ÖZTÜRK, 2015). Zhao e Chen (2011) enfatizam que a desmontagem não destrutiva e manual antes da trituração pode resultar em materiais mais puros e menor volume de resíduos.

A trituração permite que o material seja melhor classificado, mesmo quando é necessária a aplicação de técnicas de separação (CRUZ-RIVERA, 2008). Nesse sentido, Schmid, Naquin e Gourdon (2013) acrescentam mais um momento que pode provocar melhorias no processo de reaproveitamento, além dos expostos por Go et al. (2012): as operações após a trituração a partir do aprimoramento de tecnologias de separação.

Para maior aprofundamento da sequência de passos gerais, Berzi et al. (2013) colocam um empecilho: a especialização no tipo de veículo tratado. Os autores afirmam que, de forma geral, todos os centros aceitam todos os tipos de veículos em fim de vida. Isso implica em diferenças nos processos a depender da marca, do modelo, do ano de produção e das condições do veículo, fato que exige flexibilidade e robustez do sistema de reaproveitamento, principalmente quando não há contato com as montadoras.

Além disso, a alta customização nos veículos faz com que as suas partes e componentes não sejam homogêneos mesmo em modelos similares, o que dificulta o detalhamento dos passos para reaproveitamento (ENE; ÖZTÜRK, 2015).

\subsubsection{Infraestrutura e Arranjo Físico}

Para estruturação dos centros de reaproveitamento para veículos em fim de vida útil, as experiências internacionais indicam a necessidade de ampla infraestrutura e de projeto de arranjo físico. Em 2001, por exemplo, o Conselho de Estado da República Popular da China promulgou uma regulamentação de reaproveitamento de veículos em fím de vida 
útil com a especificação de área para desmontagem de pelo menos $5.000 \mathrm{~m}^{2}$ (ZHAO; CHEN, 2011).

Cruz-Rivera (2008) propõe duas configurações de arranjo físico para centros de desmontagem de veículos e orienta a segunda opção para o estágio inicial do sistema de gerenciamento de veículos em fim de vida no México.

- Arranjo físico em linha: etapas são desempenhadas em processo semi-industrializado, em unidade de $1.127 \mathrm{~m}^{2}$ e com capacidade maior que trinta veículos por dia.

- Arranjo físico funcional: etapas são desempenhadas em centros de aproximadamente $472 \mathrm{~m}^{2}$, com até cinco trabalhadores e uma capacidade menor que trinta veículos por dia.

Berzi et al. (2013) colocam que na Itália não há tamanho padrão para os centros de reaproveitamento, mas que nenhum deles possui linhas sequenciais para desmontagem e cada veículo é tratado em uma única estação ou em duas estações de trabalho (área de despoluição e de desmontagem). O veículo permanece parado e os recursos de transformação são movimentados em torno dele para realização das atividades.

Yi e Park (2015) consideram que um centro de reaproveitamento de veículos na Coréia pode ter um arranjo físico em linha ou apenas uma estação de trabalho (layout do tipo posicional), a depender do número de veículos que recebem tratamento. A pesquisa de Sohn e Park (2014) no mesmo país propõe o layout de linha, com $750 \mathrm{~m}^{2}$ e delimitação de nove diferentes estações de trabalho: recebimento, pré-tratamento, partes reutilizáveis, préestação, estações de 1 a 3, estação inclinada e prensa. A Figura 3.7 ilustra o arranjo físico proposto. 


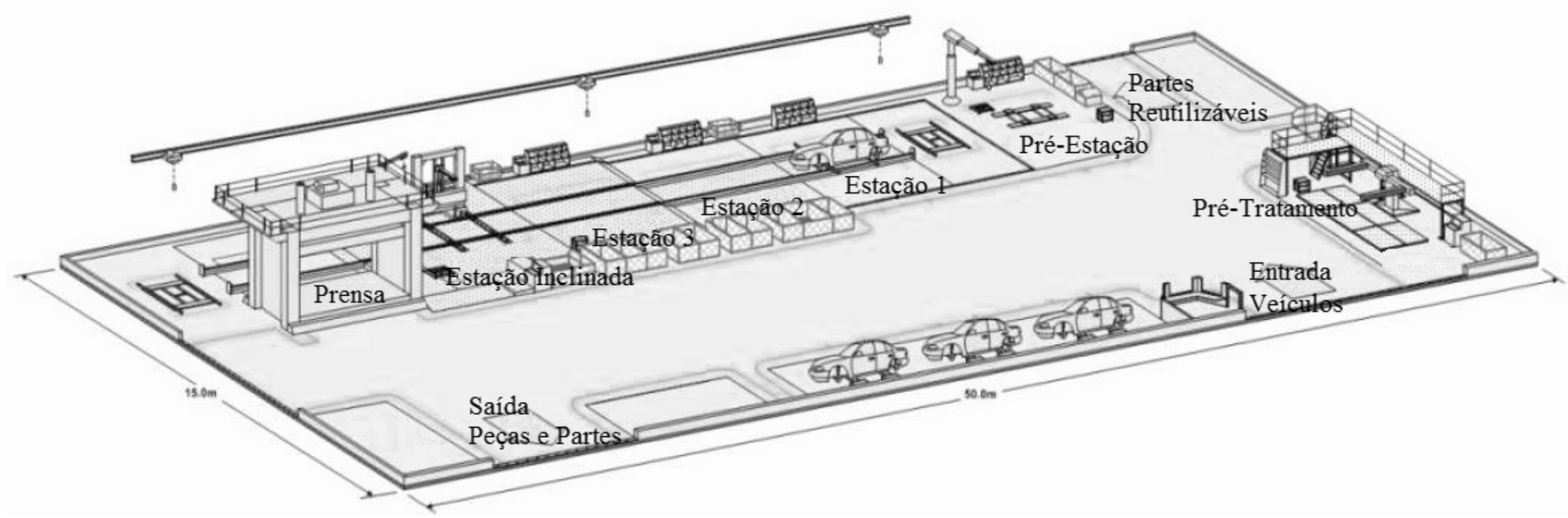

Figura 3.7 Arranjo físico proposto para desmontagem na Coréia Fonte: Sohn e Park (2014) 
A Tabela 3.3 consolida, por localidade e por autor, os tamanhos e os tipos de arranjo físico propostos. Percebe-se que o tamanho varia a partir de $472 \mathrm{~m}^{2}$ até $5.000 \mathrm{~m}^{2}$ e os tipos de layout discutidos são o posicional, funcional e de linha, com consideração de que o último deve ser utilizado em centros mais industrializados.

Tabela 3.3 Tamanho e tipo de arranjo físico em centros de reaproveitamento

\begin{tabular}{l|l|l}
\hline Localidade (Autor) & Tamanho & Tipo de Arranjo Físico \\
\hline México (CRUZ-RIVERA, 2008) & $\begin{array}{l}472 \mathrm{~m}^{2} \\
1.127 \mathrm{~m}^{2}\end{array}$ & $\begin{array}{l}\text { Funcional, com sete áreas de trabalho } \\
\text { Linha, com onze áreas de trabalho }\end{array}$ \\
\hline China (ZHAO; CHEN, 2011) & $5.000 \mathrm{~m}^{2}$ & Não especificado \\
\hline Itália (BERZI et al., 2013) & - & $\begin{array}{l}\text { Posicional com uma estação e funcional com duas } \\
\text { estações de trabalho e separação de áreas entre trabalho } \\
\text { e estoque }\end{array}$ \\
\hline Coréia (SOHN; PARK, 2014) & $750 \mathrm{~m}^{2}$ & Linha, com nove diferentes estações de trabalho \\
\hline Coréia (YI; PARK, 2015) & - & Linha ou posicional, a depender da capacidade \\
\hline
\end{tabular}

No estado de São Paulo, a Renova Ecopeças ocupa uma área ainda maior que as expostas nas referências internacionais $-6.500 \mathrm{~m}^{2}$. Nela são realizadas todas as atividades do processo de reaproveitamento de veículos e, também, são armazenadas as peças reutilizáveis para comercialização no mercado secundário. Complementar a ela, ainda existe um galpão com capacidade de estoque para 2.500 veículos recebidos da Porto Seguros, o qual deve possuir área semelhante.

Grandes infraestruturas exigem altos investimentos para instalação e manutenção. É comum que as unidades de reaproveitamento não possuam os recursos financeiros necessários e, por isso, deparam-se com a dificuldade de estruturar as atividades de acordo com as especificações da legislação e com o objetivo de redução dos impactos ambientais em ambientes significativamente menores.

\subsubsection{Capacidade de Reaproveitamento}

De acordo com Slack, Chambers e Johnston (2009, p.315), capacidade é "o máximo nível de atividade de valor adicionado em determinado período de tempo que o processo pode realizar sob condições normais de operação". Dos casos existentes, é interessante analisar a também alta capacidade média dos centros de reaproveitamento nos diferentes países.

De acordo com Zhao e Chen (2011) a capacidade de reaproveitamento de um centro chinês é maior que 500 veículos por ano. Por outro lado, a partir da experiência italiana, Berzi et al. (2013) afirmam que as plantas deveriam reaproveitar 10 mil veículos por ano e a fila de veículos temporariamente armazenados deveria ser de até 100 unidades no total. 
Em 2000, na Espanha, uma meta de capacidade foi estipulada e posteriormente atingida: estabelecimento de 950 Centros Autorizados de Tratamento (CAT) no país, cada um com capacidade média de 3 mil veículos tratados por ano (CNT, 2010). Em realidade semelhante, a Argentina, em 1995, promoveu a criação do Centro de Reciclagem de Veículos (CesviAuto) com capacidade para 2,3 mil veículos por ano (CNT, 2010).

Na Coréia, cerca de 520 centros de reaproveitamento, responsáveis pelo gerenciamento de 800 mil veículos em fím de vida útil, possuíam a capacidade média anual de 1,5 mil veículos por unidade (SOHN; PARK, 2014). Cruz-Rivera (2008) diferencia os centros de reaproveitamento com operação maior ou menor que 30 veículos por dia (aproximadamente 10,8 mil veículos anuais).

A Tabela 3.4 consolida, por localidade e por autor, a capacidade padrão dos centros de reaproveitamento de veículos em fim de vida útil. Percebe-se que elas variam de 500 a 10,8 mil veículos por ano, valores altos em relação aos experimentados pelas empresas do Distrito Federal, conforme será mostrado a seguir no diagnóstico feito nessa região.

Tabela 3.4 Capacidade em centros de reaproveitamento

\begin{tabular}{l|l}
\hline Localidade (Autor) & Capacidade \\
\hline México (CRUZ-RIVERA, 2008) & Até 10.800 veículos/ ano ou mais \\
\hline Espanha (CNT, 2010) & 3.000 veículos/ ano \\
\hline Argentina (CNT, 2010) & 2.300 veículos/ ano \\
\hline China (ZHAO; CHEN, 2011). & 500 veículos/ ano \\
\hline Itália (BERZI et al., 2013) & 10.000 veículos/ ano \\
\hline Coréia (SOHN; PARK, 2014) & 1.500 veículos/ ano \\
\hline
\end{tabular}

Nesse contexto, coloca-se que a capacidade de um centro de reaproveitamento deve ser planejada e controlada, de forma que ela possa atender à demanda. Os países referência são os que mais possuem veículos e, consequentemente, os que possuem maior urgência em tratá-los, tendo em vista o impacto que provocam.

Em países com menor frota de veículos em circulação, pode ser que os centros de reaproveitamento precisem se adaptar às demandas existentes. Assim, são essenciais as tarefas de determinar a capacidade efetiva da operação produtiva e decidir como ela deve reagir a flutuações da demanda (SLACK; CHAMBERS; JOHNSTON, 2009).

Sobre o alinhamento entre capacidade e demanda, Gołębiewski et al. (2013) colocam que o alto número de centros de desmontagem e a insuficiência de empresas trituradoras e de plantas para reciclagem de veículos em comparação com a demanda de veículos em fím de 
vida existente é um problema enfrentado por essa indústria na Polônia. Nesse sentido, é importante que a capacidade para atendimento da demanda seja planejada não apenas dentro do centro de desmontagem, mas na cadeia de reaproveitamento como um todo.

\subsubsection{Controle da Informação}

A logística reversa de materiais envolve atores, abrangência regional e aleatoriedade. Shi et al. (2012) expressam que a incerteza da logística reversa pode ser reduzida com a participação de um sistema de informação que auxilie no controle das informações. Complementarmente, Deng (2004) acredita que, a partir da análise dessas informações, as empresas podem aprimorar a velocidade de processamento do material retornado. Daugherty, Myers e Richey (2002) obtiveram, experimentalmente, resultados positivos de impacto direto entre a tecnologia da informação e o gerenciamento do desempenho.

Além de aprimorar a eficiência das atividades privadas, o sistema de informação aplicado ao reaproveitamento de materiais pode contribuir para o setor público monitorar os processos desenvolvidos (XU, 2008). Portanto, o planejamento do processo, a troca de informação, a coordenação das transações, a tomada de decisão e a alocação de recursos são inseparáveis do suporte de um sistema de informação (SHI et al., 2012).

Os sistemas de gerenciamento e de armazenamento da informação são, portanto, essenciais para o sucesso de uma logística reversa, independentemente do produto que reaproveitam (LANGNAU, 2001; YUAN; CHENG, 2009; LAMBERT; RIOPEL; ABDUL-KADER, 2011). Nesse sentido, Coelho, Gonzales-Taco e Fonseca (2016) analisaram o sistema de informação proposto pelas legislações estaduais já citadas para o controle das informações do reaproveitamento de veículos leves em fim de vida útil no estado de São Paulo, de acordo com a literatura relacionada.

Na Figura 3.8 é apresentado o mapa conceitual do sistema de informação do DETRAN-SP e, percebe-se que a própria instituição é a que possui maior número de relacionamentos e, além de receber grande parte das informações, tem a responsabilidade de disseminá-las para os demais atores (COELHO; GONZALES-TACO; FONSECA, 2016). Isso atende ao exposto por Shi et al.(2012) sobre a necessidade da gestão do sistema ser feita por empresa com funções centrais dentro do fluxo de relacionamentos, para que ela seja capaz de liderar, coletar e integrar as informações. 


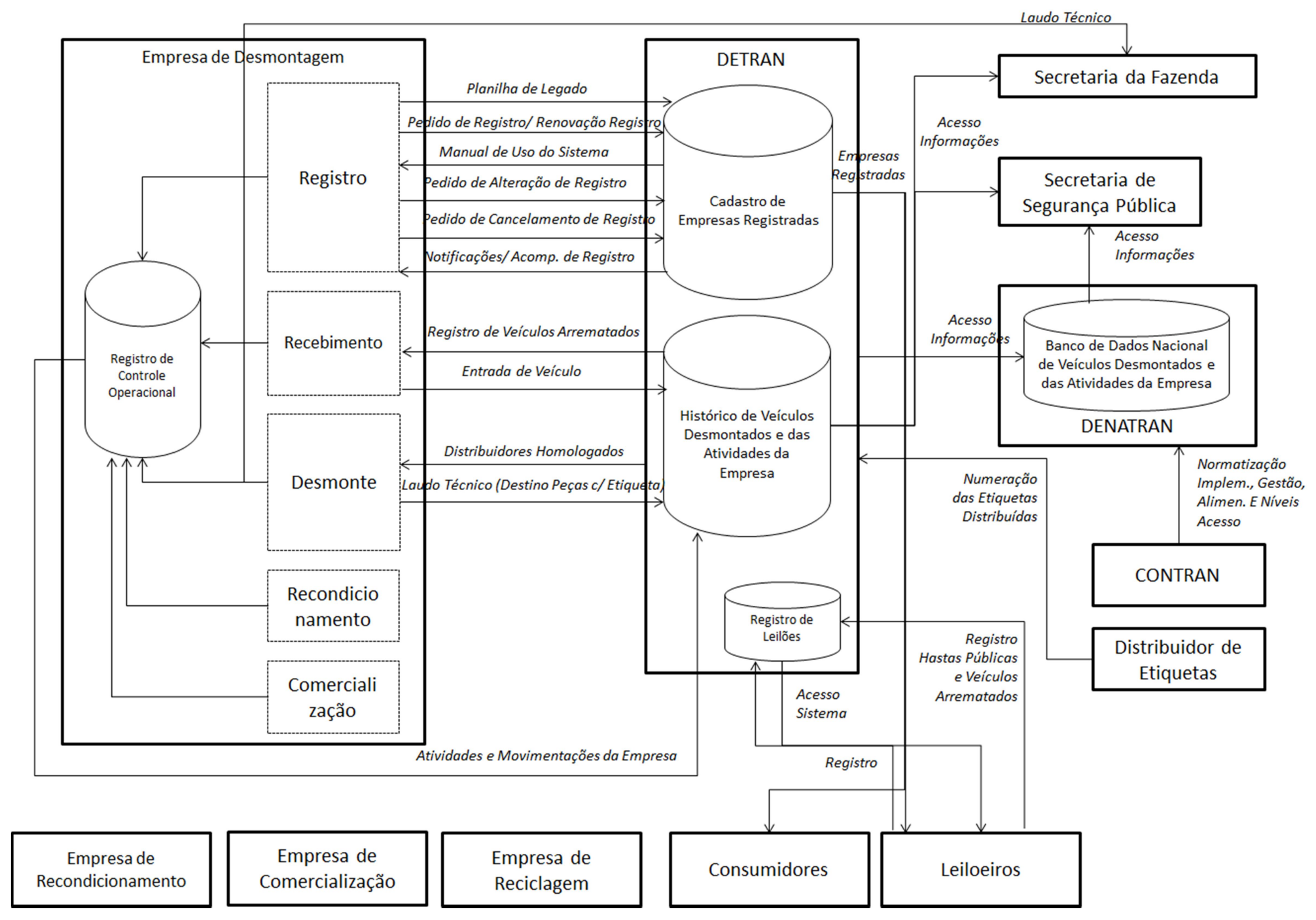

Figura 3.8 Mapa conceitual do sistema de informação do estado de São Paulo para logística reversa de veículos leves em fim de vida útil Fonte: Coelho, Gonzales-Taco e Fonseca (2016) 
Ademais, as funcionalidades expostas na Figura 3.8 estão alinhadas às expostas pela literatura: homologação de atores, identificação do produto, decisão sobre sua destinação, manutenção de comunicação entre as partes e visibilidade de status do produto ao longo da cadeia de logística reversa (COELHO; GONZALES-TACO; FONSECA, 2016).

No que diz respeito à estruturação, fica clara a presença de bancos de dados integrados às atividades realizadas, a interação dos atores envolvidos com diferentes tipos de informação, a existência de bancos de dados com funções de consolidação das informações e divulgação para interessados e, também, de fluxos de controle e fiscalização (COELHO; GONZALES-TACO; FONSECA, 2016).

Sendo assim, os autores concluem que o sistema de informação para logística reversa de veículos em fim de vida útil no estado de São Paulo está normatizado no sentido de facilitar o sucesso das atividades. Acredita-se que suas funcionalidades possam reduzir as incertezas, agilizar o processamento, facilitar o compartilhamento de informações, aumentar a colaboração entre os atores e, por isso, pode ser considerado como referência para os demais estados que ainda necessitam de sistemas próprios.

\subsection{DIAGNÓSTICO DAS EMPRESAS DE REAPROVEITAMENTO ATUANTES NO DISTRITO FEDERAL}

O mercado de reaproveitamento de veículos no Distrito Federal é realizado por pequenas empresas, parte significativa delas ainda sem regularização e estruturação. Por isso, elas podem assumir diferentes formações, bem como ser confundidas com outros tipos de empresas também relacionadas a veículos. A Figura 3.9 mostra as principais combinações existentes.

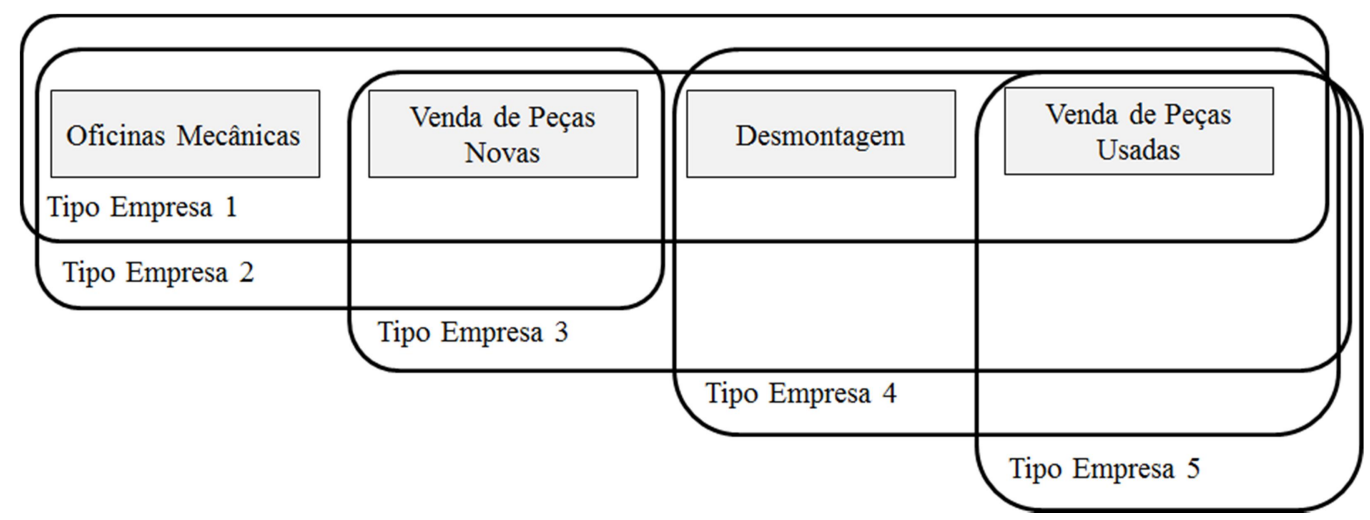

Figura 3.9 Combinações de atividades das empresas de reaproveitamento de veículos 
O tipo 1 mostra as empresas que realizam atividades de oficinas mecânicas, desmontagem e venda de peças novas e usadas. O tipo 2 foca nas oficinas mecânicas que vendem algumas peças novas para substituição. O tipo de empresa 3 realiza desmontagem de veículos, venda de peças usadas, essencialmente, mas também comercializa algumas novas.

As empresas de tipo 4 desmontam veículos e vendem apenas peças usadas. Elas representam a formação que a Lei 12.977/ 2014 almeja para todos os centros de reaproveitamento registrados pelos órgãos executivos de trânsito dos estados e do Distrito Federal. E, por fim, o tipo 5 é composto de empresas exclusivamente de comércio usado e que, para isso, compram peças de desmotadoras. Não foram consideradas na análise as empresas que não realizam a desmontagem de veículos.

Dada a combinação de atividades, parte das empresas é filiada ao Sindicato dos Comerciários do Distrito Federal (SINDICOM-DF), outra parte ao Sindicato das Indústrias Mecânicas, Reparadoras de Automóveis, Caminhões, Tratores, Motos e Autopeças do Distrito Federal (SINDIRVE) e parcela delas não possui filiação.

Esse desalinhamento na combinação de atividades e na sindicalização dificulta o levantamento sobre a quantidade de empresas que realmente realizam o reaproveitamento de veículos, no Distrito Federal. De toda forma, os dados da Secretaria de Estado de Fazenda do Distrito Federal (SEF-DF) para a cada Classificação Nacional de Atividades Econômicas (CNAE) relacionadas são os apresentados na Tabela 3.5.

Tabela 3.5 Número de empresas registradas no Distrito Federal por CNAE

\begin{tabular}{l|c}
\hline Classificação Nacional de Atividades Econômicas (CNAE) & $\begin{array}{l}\text { Empresas } \\
\text { registradas }\end{array}$ \\
\hline 4530-7/03: comércio a varejo de peças e acessórios novos para veículos automotores & 4.003 \\
\hline 4530-7/04: comércio a varejo de peças e acessórios usados para veículos automotores & 621 \\
\hline 4520-0/01: serviços de manutenção e reparação mecânica de veículos automotores & 87 \\
\hline
\end{tabular}
Fonte: adaptado de SEF-DF (2016)

A estimativa por parte do SINDIRVE é que existam 500 empresas. De fato, o CNAE mais adequado às empresas de reaproveitamento (4530-7/04) possui próximo disso: 621 . Entretanto, esse dado que não é confiável, em virtude das combinações comentadas. Pode ser que parte das empresas de CNAE 4530-7/04 não faça desmontagem, bem como parte das de CNAE 4530-7/03 venda peças novas e a realize, por exemplo. 
Além da falta de alinhamento com os sindicatos, as entrevistas realizadas com os empresários das unidades visitadas indicam que há, de forma geral, dificuldade de comunicação e relacionamento entre as empresas. As empresas, de forma geral, são resistentes a qualquer tipo de mudança na forma de trabalho desenvolvida atualmente, pois acreditam que não há maneira melhor de execução e que os resultados já são positivos o suficiente tendo em vista as condições que possuem.

Ademais, as empresas de reaproveitamento de veículos do Distrito Federal não possuem segurança para se organizarem em operações conjuntas (cooperativas) e, há indícios de que os motivos para esse comportamento estejam relacionados à existência de empresas que, de forma oculta, alimentam o mercado ilegal de peças usadas.

\subsubsection{Caracterização e Localização}

A partir dos dados da SEF-DF, apresentados na Tabela 3.6, observa-se que há uma aglomeração das empresas de CNAE 4530-7/04 do Distrito Federal nas Regiões Administrativas (RA) de Taguatinga, Ceilândia, Guará e Sobradinho, que representam juntas mais de $60 \%$ do total de 621 empresas, com destaque para as duas primeiras.

Tabela 3.6 Número de empresas de CNAE 4530-7/04 registradas por RA

\begin{tabular}{lccc}
\hline Nome da Região Administrativa & Número de empresas registradas & Percentual & Percentual Acumulado \\
\hline TAGUATINGA & 198 & $31,9 \%$ & $31,9 \%$ \\
CEILANDIA & 105 & $16,9 \%$ & $48,8 \%$ \\
GUARA & 45 & $7,2 \%$ & $56,0 \%$ \\
SOBRADINHO & 30 & $4,8 \%$ & $60,9 \%$ \\
SAMAMBAIA & 27 & $4,3 \%$ & $65,2 \%$ \\
PLANALTINA & 24 & $3,9 \%$ & $69,1 \%$ \\
AGUAS CLARAS & 23 & $3,7 \%$ & $72,8 \%$ \\
SANTA MARIA & 22 & $3,5 \%$ & $76,3 \%$ \\
GAMA & 17 & $2,7 \%$ & $79,1 \%$ \\
PLANO PILOTO & 14 & $2,3 \%$ & $81,3 \%$ \\
RECANTO DAS EMAS & 13 & $2,1 \%$ & $83,4 \%$ \\
RIACHO FUNDO & 13 & $2,1 \%$ & $85,5 \%$ \\
BRAZLANDIA & 10 & $1,6 \%$ & $87,1 \%$ \\
SAO SEBASTIAO & 10 & $1,6 \%$ & $88,7 \%$ \\
VICENTE PIRES & 10 & $1,6 \%$ & $90,3 \%$ \\
PARANOA & 8 & $1,3 \%$ & $91,6 \%$ \\
SCIA & 7 & $1,1 \%$ & $92,8 \%$ \\
ITAPOA & 6 & $1,0 \%$ & $93,7 \%$ \\
SIA & 5 & $0,8 \%$ & $94,5 \%$ \\
NUCLEO BANDEIRANTE & 4 & $0,6 \%$ & $95,2 \%$ \\
SUDOESTE & 4 & $0,6 \%$ & $95,8 \%$ \\
LAGO SUL & 3 & $0,5 \%$ & $96,3 \%$ \\
JARDIM BOTANICO & 1 & $0,2 \%$ & $96,5 \%$ \\
PARK WAY & 1 & $0,2 \%$ & $96,6 \%$ \\
FERCAL & 1 & $0,2 \%$ & $96,8 \%$ \\
\hline OUTROS & 20 & $3,2 \%$ & $100,0 \%$ \\
\hline TOTAL & 621 & $100 \%$ & $100 \%$ \\
& & & \\
\hline
\end{tabular}

Fonte:adaptado de SEF-DF (2016) 
Para a coleta de dados em campo para essa dissertação, foram escolhidas unidades de pesquisa alocadas em três das principais RA do Distrito Federal, conforme mostra a Tabela 3.6: Taguatinga (Setor H Norte), Sobradinho (Setor de Indústrias) e Ceilândia (Setor O).

Foi observada similaridade entre elas, no que diz respeito às características de localização, de tamanho, de espaço físico, de fornecedores e consumidores, de atividades, de colaboradores e de sua capacitação, de estoque e de equipamentos, constatação que foi reforçada pelos empresários a serem questionados sobre a homogeneidade das empresas. Sendo assim, as seções abaixo abordam os elementos de análise obtidos das três visitas técnicas realizadas e das observações realizadas nas RA.

As empresas de reaproveitamento de veículos do Distrito Federal alocam-se umas próximas das outras, de lojas de venda de peças automotivas e de oficinas mecânicas, em setores industriais. O posicionamento das empresas é favorável para transporte de veículos, tendo em vista a proximidade com rodovias (BR-070 e BR-010).

No que diz respeito ao descarte adequado de resíduos sólidos, os locais aonde as empresas se encontram são precários. Há muitos materiais e sobras de veículos abandonados nas vias e nos canteiros, como mostram as Figura 3.10 e Figura 3.11. Para que haja o recolhimento de resíduos, as empresas necessitam contratar um terceiro prestador desse tipo de serviço.

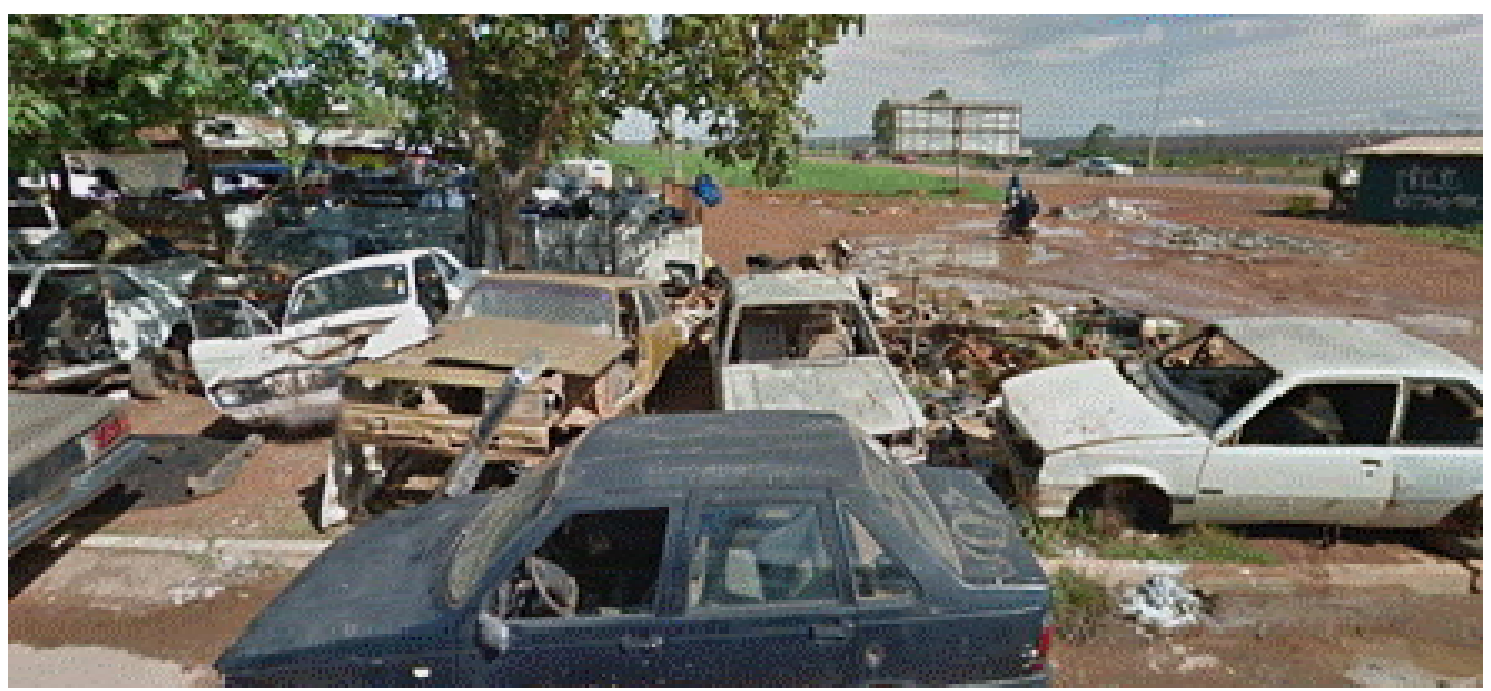

Figura 3.10 Resíduos próximos às vias de trânsito de Taguatinga 


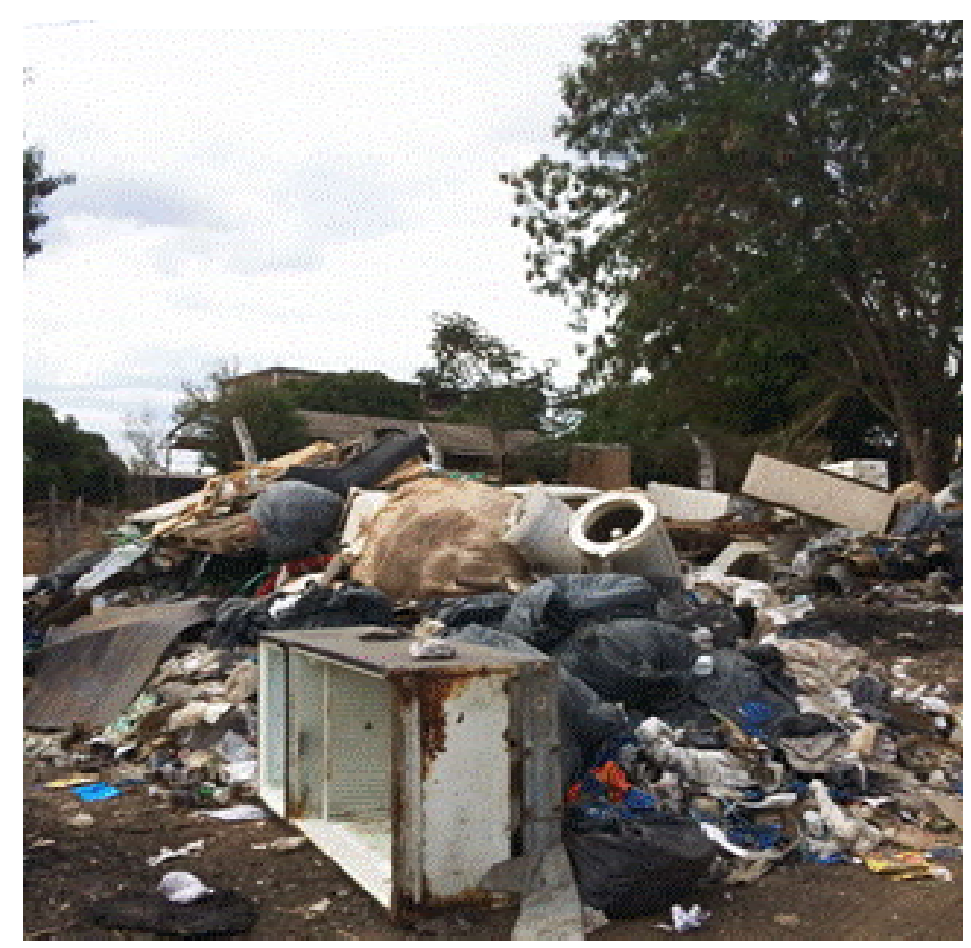

Figura 3.11 Resíduos próximos às vias de trânsito de Sobradinho

Além da quantidade de resíduos sólidos, há também disposição de veículos ainda em desmontagem nas calçadas e nas vias de trânsito. Dessa maneira, a movimentação de pedestres e de veículos em circulação é dificultada, como mostram as Figuras 3.12 e 3.13.

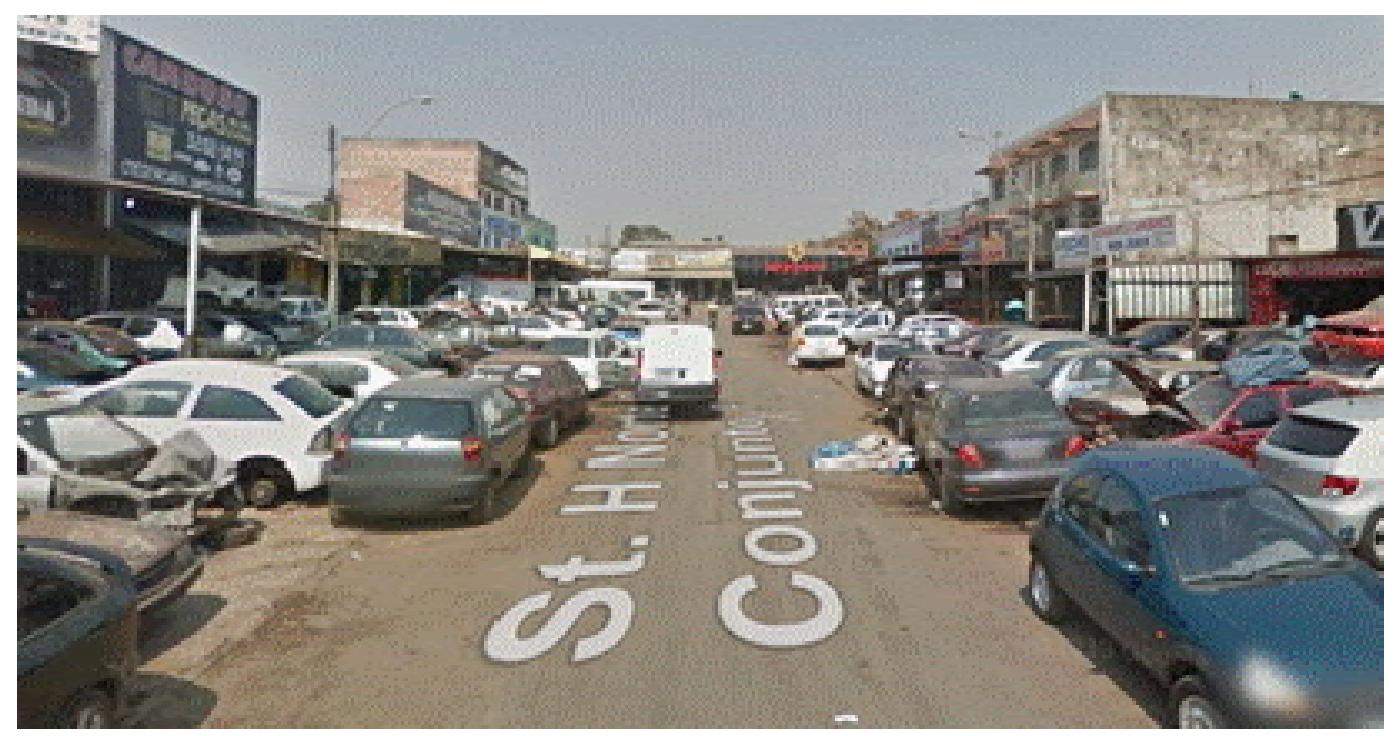

Figura 3.12 Disposição de veículos em desmontagem na via de circulação (Taguatinga) 


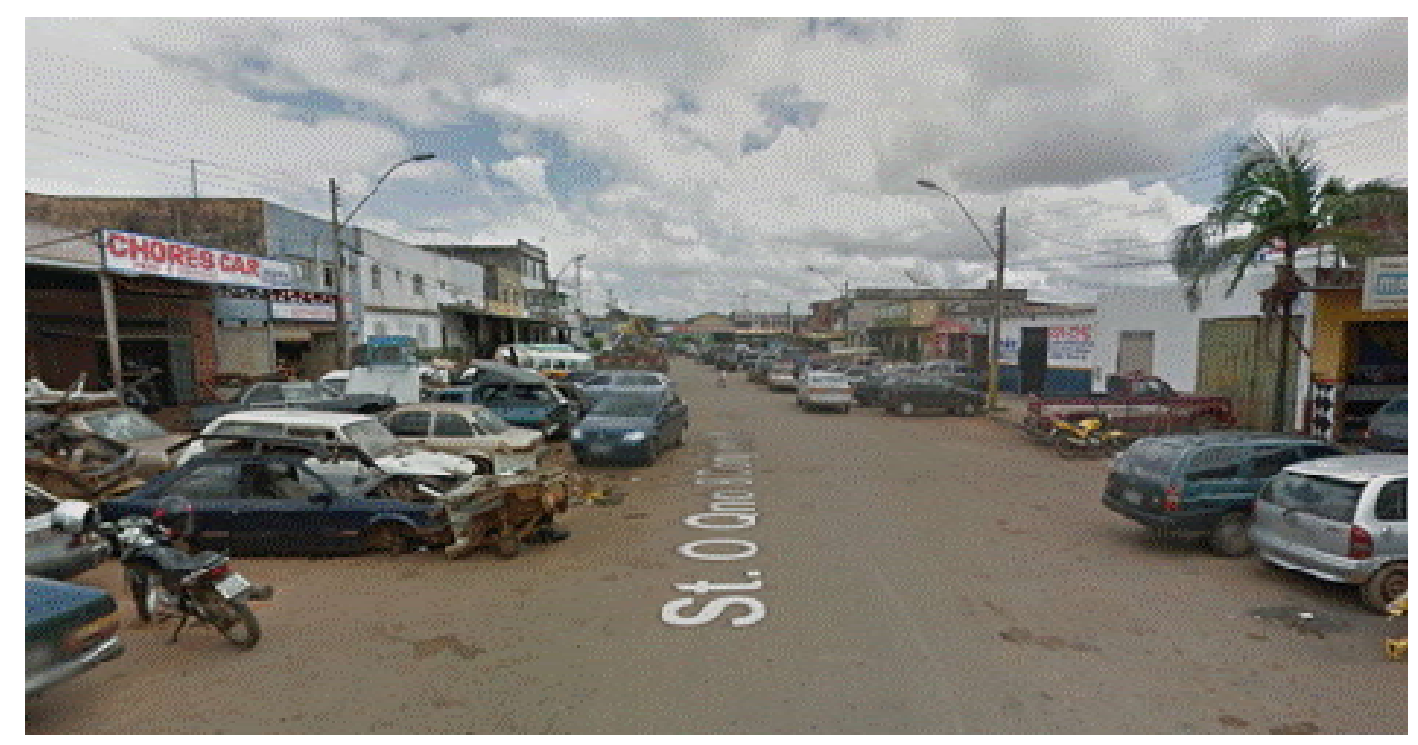

Figura 3.13 Disposição de veículos em desmontagem na via de circulação (Ceilândia)

Trabalham nas empresas em torno de dois a três funcionários, sendo vendedores e responsáveis pelo desmonte, mas sem funções bem definidas. As empresas costumam ser familiares, com os funcionários sendo membros da mesma família. A escolaridade deles é baixa, a maioria sem formação acadêmica apenas com aprendizado prático. O responsável pelas atividades administrativas (controle, aquisição de veículos) é o proprietário.

O funcionamento das empresas é no horário comercial de segunda-feira a sábado. A capacidade mensal de desmontagem varia em torno de sete a vinte veículos, o que proporciona um lucro de $\mathrm{R} \$ 15$ a $25 \mathrm{mil} / \mathrm{mês}$, características que as distanciam significativamente das empresas observadas nas experiências consideradas como referência.

Em parte das empresas, é observada a especialização em relação à marca dos veículos desmontados e, consequentemente, das peças vendidas no mercado secundário. A justificativa por essa opção ocorre, pois, ao restringir a oferta, a empresa aumenta o nível de serviço, em virtude da compatibilidade de peças de diferentes veículos pertencentes à mesma montadora.

\subsubsection{Fornecedores e Consumidores}

Os fornecedores das empresas de reaproveitamento de peças do Distrito Federal são pessoas físicas ou leiloeiros oficiais de seguradoras de veículos ou de órgãos públicos como o DETRAN e as Polícias. Cada opção possui vantagens e desvantagens, sendo a escolha de responsabilidade do empresário. A compra de pessoas físicas é incerta devido 
ao desconhecimento do histórico das peças do veículo, que podem ter sido trocadas inadequadamente. A opção por leilões oficiais reduz a preocupação com a rastreabilidade das peças dos veículos.

No que diz respeito à qualidade dos veículos, os das seguradoras costumam ser melhores que os dos órgãos públicos, em virtude de neste caso os veículos ficarem expostos ao tempo em depósitos abertos. Ademais, os órgãos públicos, diferentemente das seguradoras, costumam não permitir que os veículos sejam abertos, fato que torna a compra incerta em relação às condições internas do veículo, além de leiloarem por lotes e não por unidades. Nessa situação, acontece de um lote grande possuir poucos veículos em boas condições de conservação ou de o valor total a ser pago de uma única vez ser alto, o que pode inviabilizar a compra.

A compra de veículos pode ocorrer dentro do estado no qual a empresa de reaproveitamento se encontra, bem como em outros estados da federação. Quando em estados diferentes, a compra ocorre através de um intermediário, que realiza o serviço de avaliar a qualidade do veículo em leilão, realizar os lances, obter o veículo e a nota físcal adequada ao transporte, embarcar o veículo em cegonha contratada.

Por outro lado, os consumidores são pessoas físicas e jurídicas, estas representadas por mecânicas, oficinas e elétricas. Os principais produtos procurados são: motor, alternador, carburador, central de injeção eletrônica, câmbio, capô, farol, para-choque, com destaque para toda a parte dianteira do veículo.

Apesar de não ser uma prática recorrente, a venda pode ser realizada pela internet, através de sítios de compra e venda de itens, como o OLX e o Mercado Livre. Nessa modalidade, os consumidores podem buscar o produto no local ou o empresário é responsável por encaminhar a peça vendida via correios ou transportadora contratada para o destino.

Nesse contexto, o faturamento do centro de reaproveitamento pode ser aumentado em virtude do alcance permitido pela plataforma de venda, mas é preciso ter cautela em relação ao preço que será estabelecido para o produto. Isso porque, quando o transporte é por conta da empresa, é necessário haver uma ampla negociação para que ele tenha o menor custo possível para que a peça chegue a um valor razoável ao comprador e gere lucro ao empresário. 


\subsubsection{Infraestrutura e Equipamentos}

O espaço físico dessas empresas fica em galpões, de tamanhos que variam de 200 a $1.100 \mathrm{~m}^{2}$, a depender da região em que estão localizadas. A Figura 3.14 mostra uma imagem aérea do Setor $\mathrm{H}$ Norte em Taguatinga e destaca o tamanho relativamente padronizado das unidades $\left(200 \mathrm{~m}^{2}\right)$. Já a Figura 3.15 ilustra a vista frontal de empresas da região.

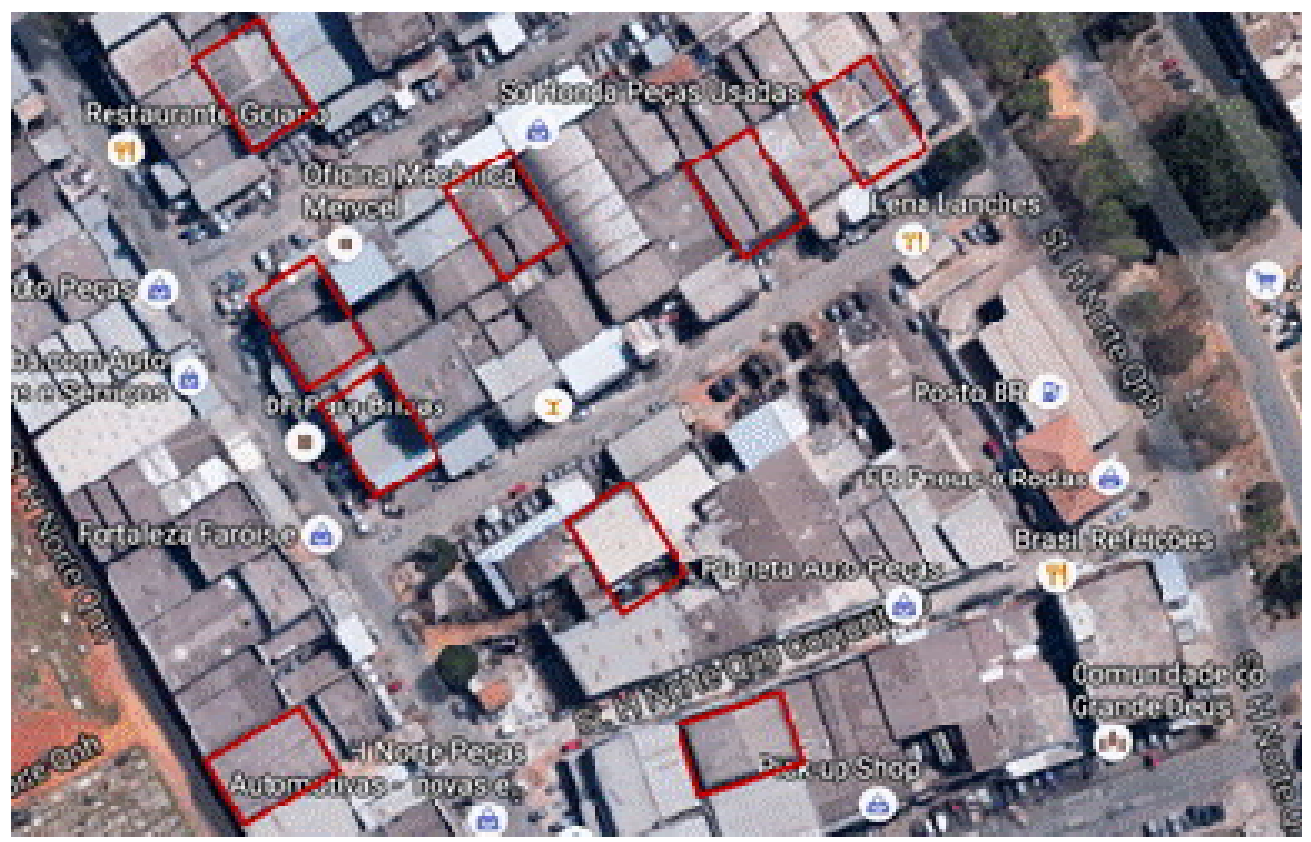

Figura 3.14 Vista aérea do Setor H Norte em Taguatinga Distrito Federal

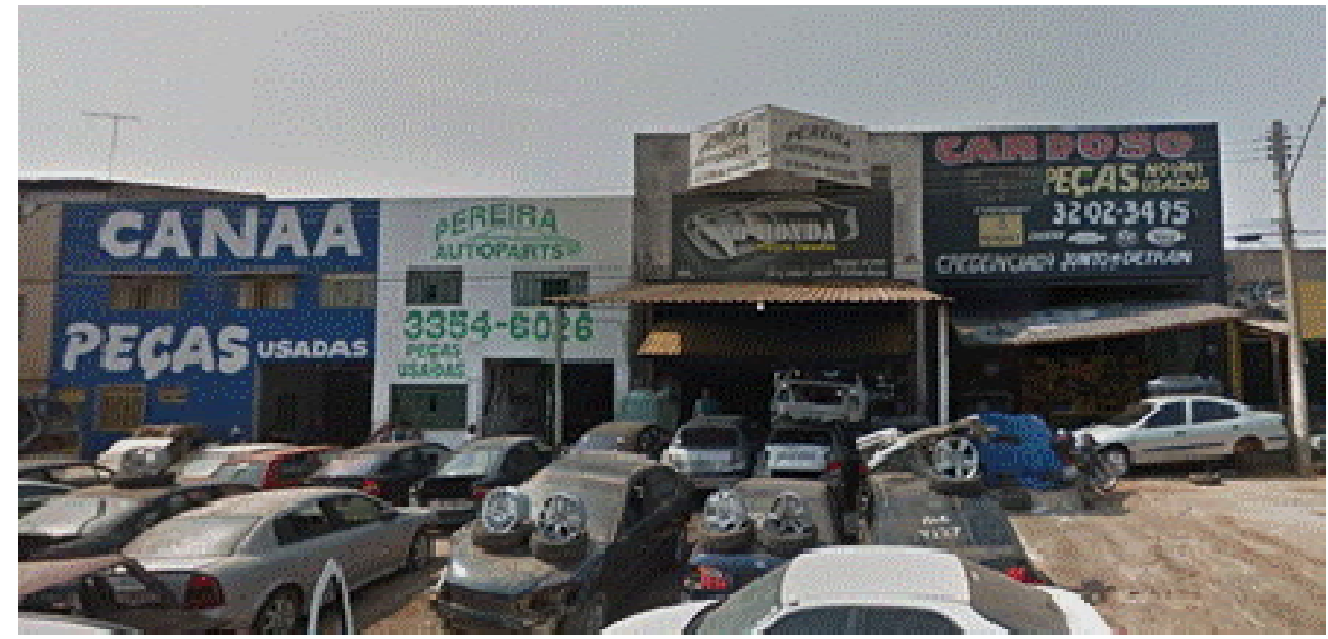

Figura 3.15 Vista frontal de empresa no Setor H Norte em Taguatinga Distrito Federal

Nas outras regiões, é mais comum encontrar empresas com espaços maiores, provavelmente em virtude do menor valor dos terrenos. De toda forma, o espaço físico é dividido em área externa e área interna. A primeira delas possui vagas de estacionamento 
para clientes e alocação de partes de veículos já desmontados, de menor valor financeiro ou de maior dificuldade de desmontagem.

A área interna, ilustrada pelas Figura 3.16, Figura 3.17 e Figura 3.18, possui balcão de atendimento, prateleiras nas quais são colocadas peças que já foram retiradas de veículos desmontados, local para atividades administrativas e espaço no qual estão dispostos os veículos em desmontagem. Elas não possuem demarcação e observa-se a falta de organização na disposição dos materiais em cada uma delas.
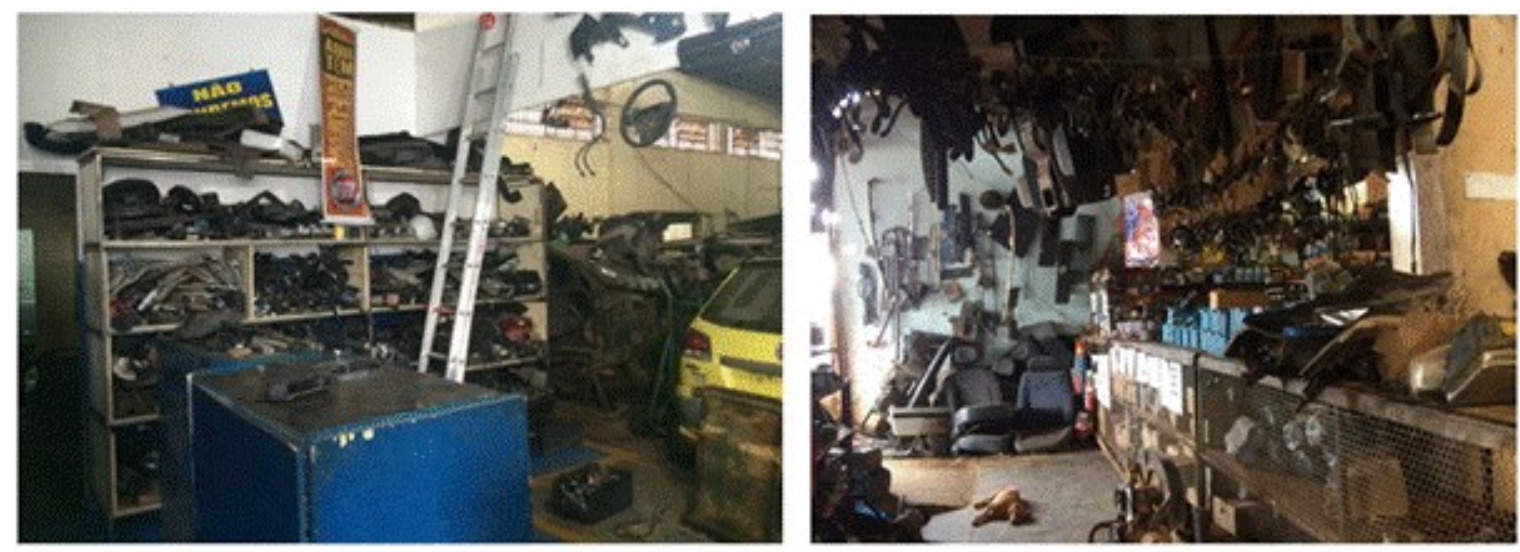

Figura 3.16 Balcão e prateleiras na área interna (a) Taguatinga e (b) Sobradinho
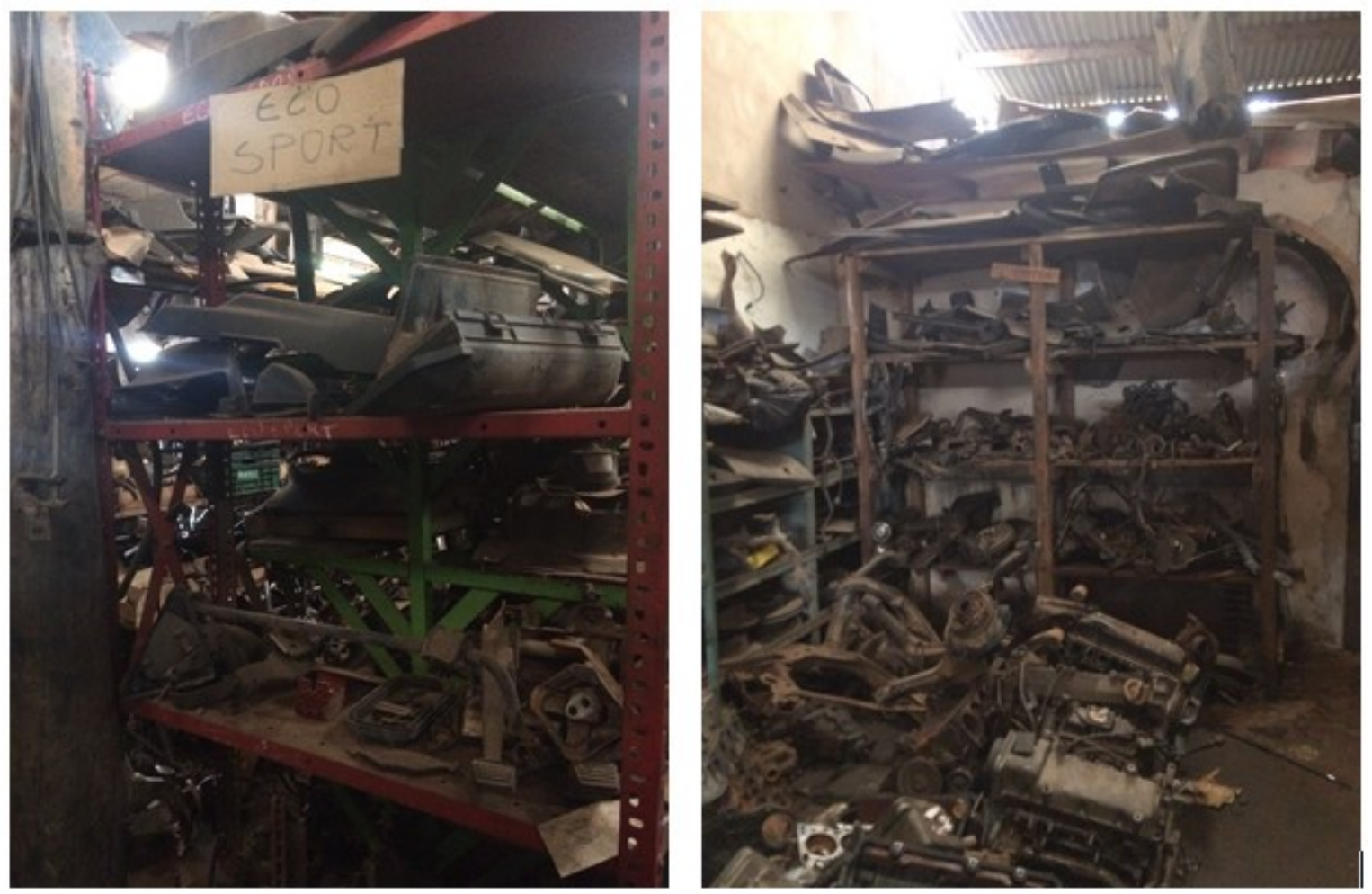

Figura 3.17 Prateleiras organizadas por modelo em Sobradinho (a) Ecosport e (b) Omega 

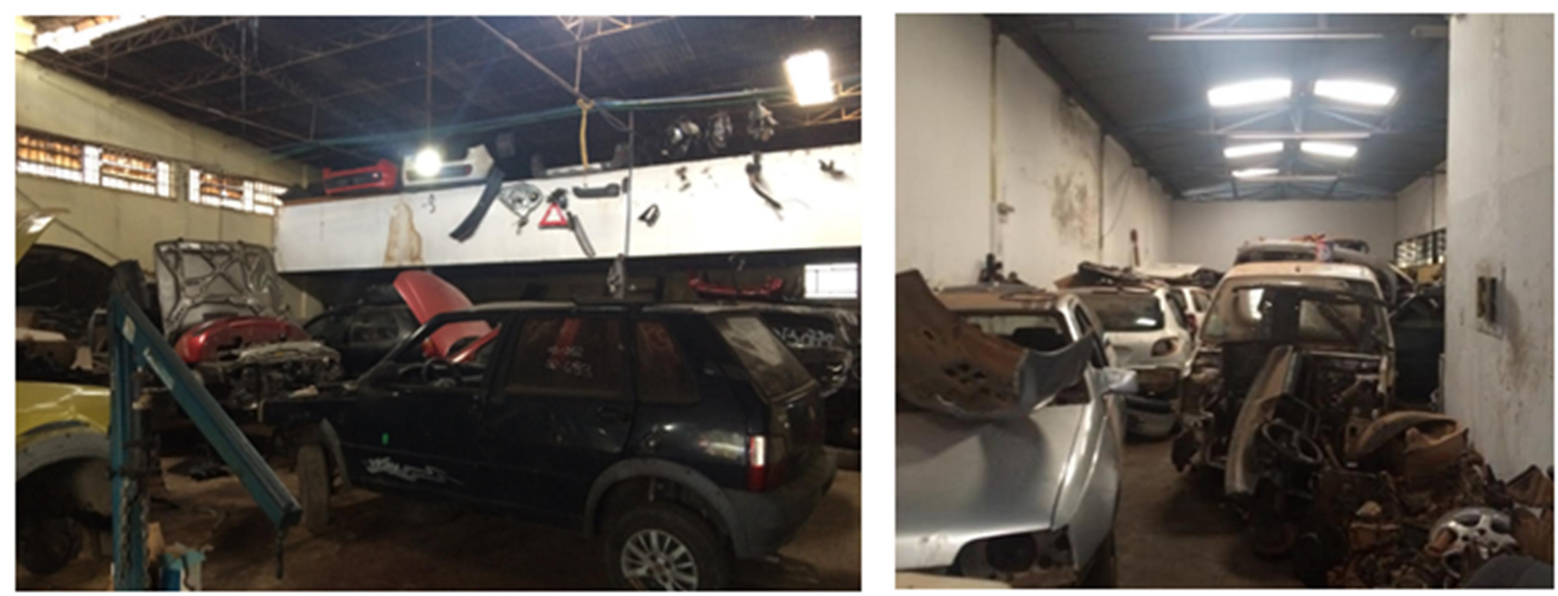

Figura 3.18 Veículos em desmontagem na área interna (a) Taguatinga e (b) Ceilândia

As áreas são relativamente iluminadas, mas possuem pouca ventilação. A limpeza e a organização das empresas podem ser melhoradas, visto que elas encontram-se sujas e possuem pintura desgastada, algumas sem acabamento. Em relação à ocupação da infraestrutura são observadas variações, havendo empresas com e sem espaços disponíveis na parte superior da área interna.

No que diz respeito aos equipamentos utilizados são ferramentas mecânicas básicas e elevadores de veículos. Uma das empresas possui instrumento para lavagem rápida de veículos e peças. A utilização de tecnologia da informação é baixa, com acesso apenas a um computador para emissão de notas fiscais eletrônicas, quando elas são utilizadas.

Não há qualquer sistema que realize o controle financeiro e/ou operacional das atividades. Uma das unidades visitadas possui registro financeiro manual sobre o valor de compra do veículo e de todas as peças retiradas dele que foram vendidas, para confirmação do valor obtido após a transformação dentro da empresa. O histórico demonstra que o valor obtido da venda de suas peças é $100 \%$ maior que o gasto com a sua aquisição.

\subsubsection{Atividades e Estoques}

Os centros de reaproveitamento de veículos em fim de vida no Distrito Federal não possuem estruturação das atividades. Elas são realizadas de acordo com o conhecimento prático dos funcionários e do proprietário, sem padronização da sequência a ser seguida tampouco do procedimento a ser utilizado.

De toda forma, foi possível identificar duas abordagens distintas para as atividades. A principal diferença entre elas está no momento no qual os centros de reaproveitamento 
realizam a desmontagem dos veículos em fim de vida útil e, consequentemente, na formação de pequenos ou grandes estoques de peças reutilizáveis para comercialização no mercado secundário.

A primeira abordagem incentiva que o início da desmontagem ocorra logo após o recebimento do veículo, independentemente do interesse de compra. Essa atividade pode ser realizada em 3 dias, mas na rotina costuma demorar um tempo maior. São retirados, conjuntamente, os óleos do veículo no local onde o veículo encontra-se posicionado, sem a existência de pisos impermeáveis. Os fluidos coletados são armazenados em tambores metálicos que são vendidos a empresas interessadas.

Em paralelo, as peças são retiradas, lavadas e armazenadas em grande estoque. Em virtude da grande formação de estoque, o proprietário se queixa sobre a perda e a dificuldade de encontrar peças quando há um cliente interessado em uma peça específica.

$\mathrm{Na}$ segunda abordagem, justamente para reduzir o aspecto negativo da perda e da possibilidade de danificação de peças por mau armazenamento, os veículos não são desmontados imediatamente à chegada, mas ficam expostos de forma íntegra, para que isso ocorra apenas quando houver interesse de compra.

Sendo assim, o veículo é recebido, lavado na área externa e posicionado na área interna da empresa. Quando não há espaço disponível, os veículos que já foram majoritariamente desmontados são transferidos para a área externa. Apenas quando há interesse por parte de um cliente na compra de uma peça, os funcionários fazem a retirada da peça desejada do veículo. Não há procedimento de limpeza ou descontaminação no que diz respeito a óleo, combustível ou lubrificante.

A comercialização de peças ocorre de maneira similar em ambas as abordagens. Primeiramente há a identificação do interesse da compra e do modelo de veículo da peça desejada pelo cliente. O funcionário verifica a disponibilidade da peça adequada no centro de reaproveitamento. Em caso de não haver, o processo é encerrado; entretanto, se há a peça na unidade, ela é mostrada para o cliente.

Pode ser que isso seja realizado a partir de peça já retirada do veículo ou de uma que ainda se encontre instalada nos veículos expostos. Neste caso, se houver confirmação da compra, o funcionário ainda precisará retirá-la. Essa é a única diferença entre a comercialização das 
abordagens. Em seguida, é feita a formalização da venda com o pagamento do valor combinado, com a emissão da nota fiscal e com as orientações sobre o uso adequado da peça, se for o caso.

No que diz respeito à garantia e à troca de peças, elas existem. Em caso de as peças estarem defeituosas ou inadequadas, pode ocorrer análise e troca pelo centro de reaproveitamento, podendo o cliente ter, inclusive, seu dinheiro devolvido. Isso é recorrente, tendo em vista que a peça não é testada antes de ser vendida.

\subsubsection{Quantidade de Veículos em Fim de Vida Útil no Distrito Federal}

Como dito anteriormente (seção 3.4.3), é essencial que o centro de reaproveitamento organize-se a partir da demanda que precisam atender. $\mathrm{O}$ conhecimento da demanda possibilita que ele reaja melhor ao seu papel dentro da cadeia de reaproveitamento, às tendências de crescimento ou retração, às sazonalidades, às preferências por montadora e/ou modelo, às parcerias que devem ser feitas com as empresas especializadas nas diferentes estratégias de gerenciamento (renovação, reparação, recondicionamento, remanufatura, reciclagem, recuperação).

Assim, com o intuito de reforçar a importância e, também, a oportunidade que significa a melhoria dos centros de reaproveitamento no Distrito Federal, foram feitas algumas considerações sobre a tendência de demanda existente para essa localidade. Isso foi discutido a partir da quantidade de veículos leves em fim de vida útil que deverão passar pelo referido processo e da sua tendência de crescimento para os próximos anos, conforme as etapas utilizadas por Coelho et al. (2016).

Nesse contexto, considera-se que a partir da Lei 12.977/ 2014 ocorrerá uma mobilização no mercado de veículos leves em fim de vida útil no sentido de que eles sejam realmente encaminhados aos centros responsáveis pelo seu tratamento para obtenção dos impactos positivos ressaltados na seção 1.3.

Os veículos encaminhados aos centros de reaproveitamento podem ser veículos que prematuramente perderam a possibilidade de circulação ou veículos com idade avançada. A demanda para reaproveitamento de veículos em fim de vida útil no DF foi, portanto, estimada a partir de dados da quantidade de veículos leiloados como sucata pelo DETRAN-DF e da quantidade de veículos em circulação com idade avançada no DF (DENATRAN). 
Já nesse momento, deve ser feita a consideração de que a quantidade de veículos leiloados por seguradoras no DF também deveria ser considerada, entretanto, ela não foi obtida, apesar dos contatos realizados com o Sindicato dos Corretores de Seguros, Empresas Corretoras de Seguro, Capitalização e Previdência Privada no Distrito Federal (SINDICOR-DF), a Confederação Nacional das Empresas de Seguros Gerais, Previdência Privada e Vida, Saúde, Suplementar e Capitalização (CNseg), Federação Nacional de Seguros Gerais (FenSeg) e a Superintendência de Seguros Privados (SUSEP). A justificativa é que esses dados são específicos de cada seguradora e possuem valor estratégico.

A quantidade anual de veículos leiloados como sucata representa a parcela de veículos que foram apreendidos por quaisquer ocorrências, permaneceram nos depósitos do DETRANDF por tempo determinado e foram leiloados com impossibilidade de circulação, seja por sinistro ocorrido ou por efeitos do tempo. Os veículos não são classificados como sucata apenas em virtude do tempo de fabricação. A Tabela 3.7 mostra esse dado para os anos de 2011 a 2015.

Tabela 3.7 Quantidade de veículos leiloados por ano como sucatas

\begin{tabular}{|c|c|c|c|}
\hline Ano & Leilão & Quantidade por Leilão & Quantidade por Ano \\
\hline \multirow{3}{*}{2011} & $01 / 2011$ & 827 & \multirow{3}{*}{2532} \\
\hline & $02 / 2011$ & 967 & \\
\hline & $03 / 2011$ & 738 & \\
\hline \multirow{3}{*}{2012} & $01 / 2012$ & 883 & \multirow{3}{*}{2753} \\
\hline & $02 / 2012$ & 1083 & \\
\hline & $03 / 2012$ & 787 & \\
\hline \multirow{2}{*}{2013} & $01 / 2013$ & 538 & \multirow{2}{*}{1590} \\
\hline & $02 / 2013$ & 1052 & \\
\hline \multirow{3}{*}{2014} & $01 / 2014$ & 884 & \multirow{3}{*}{4352} \\
\hline & $02 / 2014$ & 1571 & \\
\hline & $03 / 2014$ & 1897 & \\
\hline \multirow{3}{*}{2015} & $01 / 2015$ & 1394 & \multirow{3}{*}{3398} \\
\hline & $02 / 2015$ & 1591 & \\
\hline & $03 / 2015$ & 413 & \\
\hline
\end{tabular}

Fonte: adaptado de DETRAN-DF (2016)

Pela Tabela 3.7 percebe-se que ocorreram três leilões por ano, com exceção de 2013, no qual aconteceram dois. A média de veículos vendidos por leilão foi em torno de mil, mas esse valor teve grande variação a depender do ano e do período de realização do leilão. Nos dois últimos anos percebe-se um aumento significativo em relação aos três primeiros. 
Já a quantidade de veículos em circulação com idade avançada pode ser retirada dos dados da frota de veículos do DENATRAN. Entretanto, observa-se que os dados disponibilizados por ano de fabricação dos veículos não diferenciam os veículos por tipo. Considerando que essa dissertação aborda apenas os veículos leves (automóveis e camionetas, de acordo com o CTN), é necessário fazer um ajuste para que a demanda não seja estimada a maior.

Sendo assim, a decisão tomada foi a de considerar dos dados totais apenas a proporção dos veículos que são objeto de estudo (76\%), conforme explicitado na seção 2.2.1. Sabe-se que essa estimativa pode não representar totalmente a realidade tendo em vista que veículos pesados tendem a circular até uma faixa etária mais alta. Entretanto, considerando que eles (caminhão, caminhão trator, caminhonete, micrônibus, ônibus) representam $9 \%$ da frota em circulação e que o intuito do levantamento é apenas de enfatizar relevância dos centros de reaproveitamento, foi possível fazê-lo, mesmo assim.

Ademais, por não haver consenso na literatura sobre a idade para determinação do fim de vida de um veículo, serão considerados três cenários: idade avançada equivalente a dez, quinze e vinte anos contados da data de fabricação. Eles são apresentados na Tabela 3.8.

Tabela 3.8 Quantidade de veículos em circulação com idade avançada por ano

\begin{tabular}{cccc}
\hline \multicolumn{4}{c}{ Quantidade de Veículos com Idade Avançada } \\
\hline \multirow{2}{*}{ Ano } & $\begin{array}{c}\text { Cenário 1 } \\
\text { Idade Avançada de 10 anos }\end{array}$ & $\begin{array}{c}\text { Cenário 2 } \\
\text { Idade Avançada de 15 anos }\end{array}$ & $\begin{array}{c}\text { Cenário 3 } \\
\text { Idade Avançada de 20 anos }\end{array}$ \\
\hline 2011 & 327.612 & 205.692 & 123.878 \\
2012 & 353.327 & 233.308 & 131.960 \\
2013 & 378.847 & 255.426 & 146.056 \\
2014 & 408.647 & 274.712 & 163.231 \\
2015 & 442.059 & 300.483 & 184.102 \\
\hline
\end{tabular}

Fonte: adaptado de DENATRAN (2016)

A Tabela 3.8 mostra que, considerados os dados cronológicos, independente do cenário de idade avançada (dez, quinze ou vinte anos), a tendência no número de veículos é crescente ao longo dos anos de 2011 a 2015. Considerando os veículos com mais quinze anos como veículos com idade avançada (cenário 2), observa-se que as quantidades são de 205.692 em 2011 e de 300.483 em 2015.

A Tabela 3.9, por outro lado, mostra os dados referentes aos três cenários apresentados na Tabela 3.8 com adição dos veículos leiloados como sucata, abordados na Tabela 3.7. Sendo assim, são considerados como dados históricos dos veículos em fim de vida útil no 
Distrito Federal nos anos de 2011 a 2015, com a consideração dos dados dos leilões das seguradoras, que não foram obtidos, conforme dito.

Tabela 3.9 Quantidade de veículos em fim de vida útil no DF por ano

\begin{tabular}{cccc}
\hline \multicolumn{4}{c}{ Quantidade de Veículos em Fim de Vida Útil } \\
\hline \multirow{2}{*}{ Ano } & $\begin{array}{c}\text { Cenário 1 } \\
\text { Idade Avançada de 10 anos }\end{array}$ & $\begin{array}{c}\text { Cenário 2 } \\
\text { Idade Avançada de 15 anos }\end{array}$ & $\begin{array}{c}\text { Cenário 3 } 3 \\
\text { Idade Avançada de 20 anos }\end{array}$ \\
\hline 2011 & 330.144 & 208.224 & 126.410 \\
2012 & 356.080 & 236.061 & 134.713 \\
2013 & 597.263 & 473.842 & 364.472 \\
2014 & 412.999 & 279.064 & 167.583 \\
2015 & 445.457 & 303.881 & 187.500 \\
\hline
\end{tabular}

Fonte: adaptado de DETRAN-DF (2016) e DENATRAN (2016)

Os valores da Tabela 3.9 foram insumo para a identificação da tendência de crescimento da demanda para o reaproveitamento de veículos nos anos de 2016 a 2025. Nesse sentido, foi realizada uma regressão linear simples dos dados obtidos para os três cenários levantados: idade avançada com 10, 15 e 20 anos, respectivamente. A Figura 3.19 mostra o resultado disso.

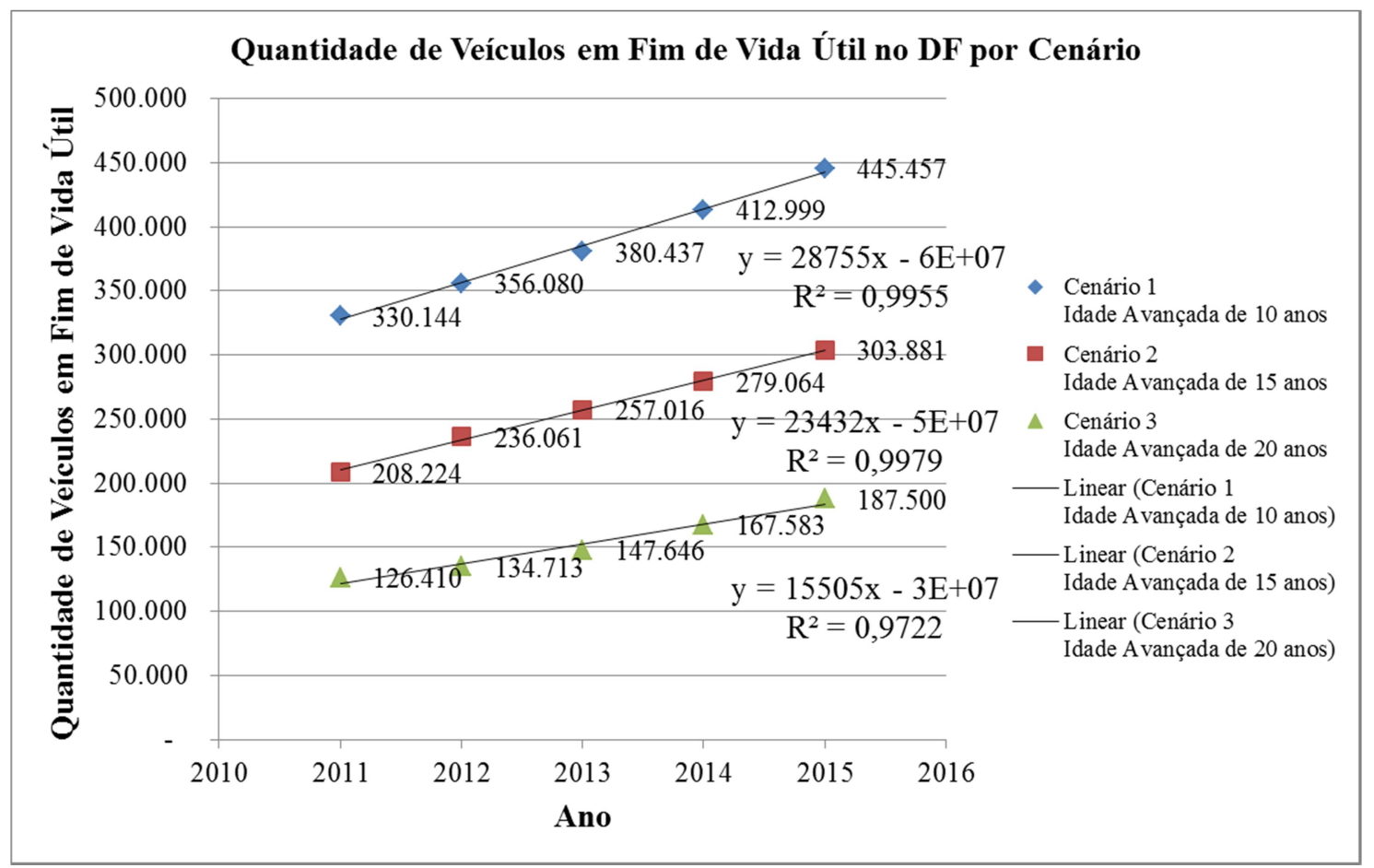

Figura 3.19 Modelo da quantidade de veículos em fim de vida útil por cenário

$\mathrm{Na}$ Figura 3.19, os três cenários são representados pelas equações delineadas pela regressão linear simples. Os resultados do coeficiente de determinação $\left(\mathrm{R}^{2}\right)$ próximos de 1 indicam que o modelo de regressão está ajustado à explicação dos dados de quantidade de veículos em fim de vida útil. 
A partir das equações obtidas, as tendências de crescimento anual para cada um dos três cenários foram identificadas - 28.755 (cenário 1), 23.432 (cenário 2), 15.505 (cenário 3). Isso significa que, além dos veículos que estão em circulação já com mais de 10, 15 e 20 anos, respectivamente, a quantidade de veículos em fim de vida aumentará anualmente em torno desses valores.

A intenção nesse momento não foi aprofundar especificamente no número de veículos que comporão a demanda para os centros de reaproveitamento. Isso deve ser feito em pesquisas futuras. O objetivo foi reforçar como a tendência de crescimento dos veículos em fím de vida útil é significativa dentro da realidade apresentada do Distrito Federal.

Tendo em vista que a capacidade média atual dos centros é de 180 veículos por ano, mesmo o menor dos crescimentos, que é o do cenário 3 (15.505 veículos anuais), já permitiria a operação de aproximadamente 86 centros de reaproveitamento. No cenário 1 , que considera veículos com mais de 10 anos como em fim de vida útil, o número de unidades necessárias para atendimento da demanda passa para 159.

Além disso, nessa colocação não são considerados os veículos que estão circulando já em vida de útil nos dados de 2015 e que representam um estoque significativo de veículos com idade avançada: 445.457 (cenário 1), 303.881 (cenário 2), 187.500 (cenário 3). Considerando que eles sejam encaminhados aos centros de reaproveitamento gradativamente em 10 anos, além da tendência de crescimento anual, a demanda será composta de mais 44.545, 30.388, 18.750 veículos em fim de vida útil.

Dessa maneira, a quantidade anual de veículos a serem tratados pelos centros de reaproveitamento no Distrito Federal fica em 73.300 no cenário 1, 53.820 no cenário 2 e 34.255 no cenário 3 , como mostra a Tabela 3.10. Nela, também se percebe que o número de centros de reaproveitamento, com média de capacidade de 180 veículos anuais, necessários ao atendimento da demanda é interessante.

Tabela 3.10 Consolidação dos dados da demanda anual estimada para três cenários

\begin{tabular}{l|c|c|c|c}
\hline $\begin{array}{l}\text { Cenário de idade } \\
\text { avançada }\end{array}$ & $\begin{array}{l}\text { Tendência anual } \\
\text { de crescimento }\end{array}$ & $\begin{array}{l}\text { Redução anual de } \\
\text { estoques }\end{array}$ & $\begin{array}{l}\text { Demanda anual } \\
\text { estimada }\end{array}$ & $\begin{array}{l}\text { Número de centros } \\
\text { de reaproveitamento }\end{array}$ \\
\hline Cenário 1 & 28.755 & 44.545 & 73.300 & 407 \\
\hline Cenário 2 & 23.432 & 30.388 & 53.820 & 299 \\
\hline Cenário 3 & 15.505 & 18.750 & 34.255 & 190 \\
\hline
\end{tabular}

Por fim, ressalta-se que a quantidade de veículos em fim de vida útil tratados no Distrito Federal não depende apenas dos veículos registrados nessa localidade. Os dados referentes 
à troca que ocorre entre estados não são disponíveis. Mas, tendo em vista a pesquisa de campo realizada com empresários do Distrito Federal, acredita-se que a região é mais importadora de veículos para reaproveitamento de peças que exportadora, aumentando a demanda discutida.

As discussões realizadas sobre a quantidade de veículos em fim de vida útil ressaltam as possibilidades para reaproveitamento desse tipo de produto no Distrito Federal nos próximos anos. Ademais, acredita-se que o aprimoramento dos modelos para atendimento das exigências impostas pela legislação e para alinhamento com as boas práticas identificadas será capaz de tornar as unidades de tratamento do Distrito Federal mais preparadas e estruturadas para o atendimento dessa demanda. 


\section{MODELO DE CENTRO DE REAPROVEITAMENTO PARA VEÍCULOS LEVES EM FIM DE VIDA ÚTIL NO DF}

Tendo em vista as práticas de outros países, a recente legislação brasileira sobre desmontagem de veículos leves em fim de vida útil, a experiência para cumprimento das exigências de empresas do estado de São Paulo e o contexto atual de gerenciamento dos veículos em fim de vida útil no Distrito Federal, observou-se que será necessário um período de adaptação e melhoria para definição e alcance do modelo ótimo de centro de reaproveitamento.

A complexidade do sistema de gerenciamento dos veículos em fim de vida útil não permite que sejam transferidos diretamente os modelos de outros países ou até mesmo de outro estado, basicamente porque a implementação não seria factível, em virtude da cultura instalada e das condições disponíveis. A escassa disponibilidade de dados relacionados também não permite projetar detalhadamente o modelo ótimo para o Distrito Federal.

Sendo assim, essa dissertação assume o desenvolvimento, a implementação e o aprimoramento gradual do modelo para os centros de reaproveitamento do Distrito Federal, separado em estágios, a começar pelo estágio inicial (adaptação da realidade atual para uma condição de atendimento da legislação e de cuidado com os impactos ambientais), passando por estágios intermediários de melhorias até o alcance do estágio que venha a ser considerado como ótimo.

Dessa maneira, para o modelo de estágio inicial, sobre o qual essa dissertação diz respeito, foram estipulados os seguintes objetivos específicos:

- Adequação e estruturação das atividades para atendimento às regulamentações brasileiras e para redução dos impactos ambientais;

- Adequação da infraestrutura, dos recursos humanos e capitais necessários para condução das atividades propostas;

- Implementação da coleta de dados, para aprimoramento quantitativo dos processos de reaproveitamento propostos, em estágios posteriores;

- Incentivo ao uso de ferramentas de simulação para otimização dos processos do centro de reaproveitamento de veículos em fim de vida útil no DF, em estágios posteriores. 
Nesse contexto, algumas considerações precisam ser ressaltadas para que haja compreensão em relação às decisões tomadas ao longo da proposição do modelo:

- Não há previsão de políticas públicas no sentido de fomentar ou financiar a adaptação e a instalação de centros industriais da cadeia de reaproveitamento de veículos, mas espera-se que o governo do Distrito Federal e, principalmente, o órgão executivo de trânsito do Distrito Federal divulguem e incentivem o modelo proposto.

- O órgão executivo de trânsito do Distrito Federal deve implementar, coordenar e controlar, conforme estipula a Lei 12.977/ 2014, um sistema de informação adequado para obtenção, manipulação e divulgação de dados referentes às operações dos centros de reaproveitamento de veículos.

- As empresas de reaproveitamento de veículos do Distrito Federal não possuem interesse, abertura e/ou segurança inicial para se organizarem em operações conjuntas (cooperativas). Sendo assim, esse fato que é considerado como restrição a alguns elementos do modelo (capacidade, recursos, infraestrutura), que, por isso, não podem ser bruscamente alterados no estágio inicial.

Feitas as considerações gerais cabíveis no âmbito do modelo proposto para o centro de reaproveitamento de veículos em fim de vida, as próximas seções abordam elementos importantes dos processos dessa unidade produtiva - objetivo e caracterização - e, em seguida, aprofundam e detalham as atividades, pessoas, equipamentos e infraestrutura, tornando a sua implementação acessível.

Por fim, a proposição é traduzida por uma ferramenta que auxilia na representação das fronteiras, da estrutura e das regras de interação de um modelo para simulação - o diagrama de laço causal. E, por fim, o capítulo encerra com a apresentação de uma proposta para controle das informações do modelo proposto (estágio inicial) para que, posteriormente, ele possa ser otimizado com auxílio de ferramentas de simulação.

\subsection{OBJETIVO DO PROCESSO DE REAPROVEITAMENTO}

O objetivo principal de modelar um processo, ou seja, de propor uma estrutura antes de realmente contruí-la é justamente assegurar que o seu funcionamento seja adequado ao que ele esteja tentando alcançar (SLACK; CHAMBERS; JOHNSTON, 2009). Por isso a importância de explicitar os objetivos do centro de reaproveitamento, objeto de estudo. 
Sendo assim, o centro de reaproveitamento de veículos leves em fim de vida útil no Distrito Federal tem como principal finalidade garantir a qualidade e a confiabilidade do processamento e dos produtos resultantes da logística reversa desse tipo de produto. Assim, os impactos ambientais provocados por eles serão reduzidos, uma série de problemas para saúde e segurança públicas será evitada e o mercado de reaproveitamento será impulsionado.

Nesse sentido, percebe-se que a estruturação do centro de reaproveitamento está intimamente relacionada aos produtos que dele irão resultar. Slack, Chambers e Johnston (2009) reforçam esse relacionamento ao colocarem que pequenas mudanças no produto podem ter consequências no seu modo de produção e vice-versa.

A Tabela 4.1 aprofunda os objetivos do centro de reaproveitamento tendo em vista os processos que serão realizados (aquisição, recebimento, liberação, despoluição, desmontagem, análise técnica, armazenamento e saída), bem como os produtos que se pretende entregar (partes reutilizáveis e não reutilizáveis de veículos leves).

Tabela 4.1Objetivos do centro de reaproveitamento de veículos em fim de vida útil

\begin{tabular}{|c|c|c|}
\hline & $\begin{array}{c}\text { Qualidade } \\
\end{array}$ & $\begin{array}{c}\text { Confiabilidade } \\
\end{array}$ \\
\hline 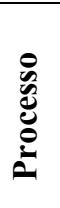 & $\begin{array}{l}\text {-Realizar o processo de reaproveitamento de } \\
\text { veículos em fim de vida de acordo com a } \\
\text { regulamentação } \\
\text {-Realizar o processo de reaproveitamento com } \\
\text { atenção aos impactos ambientais }\end{array}$ & $\begin{array}{l}\text {-Coletar dados confiáveis para os sistemas de } \\
\text { informação próprios e do órgão executivo de } \\
\text { trânsito }\end{array}$ \\
\hline$\stackrel{\stackrel{0}{ٍ}}{\stackrel{0}{0}}$ & $\begin{array}{l}\text {-Comercializar direta ou indiretamente peças } \\
\text { de qualidade para o mercado secundário } \\
\text {-Comercializar partes ou elementos do veículo } \\
\text { em fim de vida para posterior gerenciamento } \\
\text {-Dispor adequadamente os resíduos } \\
\text { originários do processo de reaproveitamento } \\
\text { de veículos }\end{array}$ & $\begin{array}{l}\text {-Comercializar direta ou indiretamente peças } \\
\text { com rastreabilidade confiável para o mercado }\end{array}$ \\
\hline
\end{tabular}

A partir dos objetivos de desempenho definidos para os processos de reaproveitamento é possível caracterizá-los de acordo com o volume e a variedade de produto esperados.

\subsection{CARACTERIZAÇÃO DO PROCESSO DE REAPROVEITAMENTO}

Nas experiências internacionais levantadas, a capacidade dos centros de reaproveitamento varia de 500 a mais de 10.800 veículos anuais, valores muito maiores que os observados no Distrito Federal. Cruz-Rivera (2008) não estabelece o mínimo de processamento, mas 
coloca o patamar de 10.800 veículos anuais como divisória entre um centro pequeno e um semi-industrializado.

No Brasil, de acordo com a Lei 12.977/ 2014, a atividade de desmontagem de veículos será exercida em regime de livre concorrência. É vedado aos entes públicos fixar preços de atividades relacionadas à desmontagem, limitar o número de empresas ou o número de locais em que a atividade referida pode ser exercida ou estabelecer regra de exclusividade territorial. Sendo assim, o próprio mercado será o responsável por alinhar a capacidade dos centros à demanda existente.

Dado que a proposta de modelo considera o estágio inicial, o volume de processamento do centro de reaproveitamento não será alterado em relação ao obtido no diagnóstico com as empresas do Distrito Federal que atuam no mercado. Sendo assim, a capacidade deve variar próximo de 15 veículos mensais ou 180 veículos anuais por unidade produtiva. Esse volume é baixo em relação às experiências internacionais, mas é uma restrição colocada pelo contexto do Distrito Federal, no qual as empresas não querem se juntar.

Em relação à variedade, ela pode ser considerada alta em virtude da elevada diferenciação entre os veículos (montadoras, modelos, ano de fabricação, itens acessórios, condição de circulação e de manutenção). Em um mesmo mês os veículos recebidos e reaproveitados são variados, principalmente considerando o baixo volume de processamento e a ampla gama de possibilidades no mercado de veículos leves em fim de vida útil.

Dessa maneira, dentro dos tipos de processo produtivo propostos por Slack, Chambers e Johnston (2009), o centro de reaproveitamento é caracterizado como processo de jobbing, como mostra a Figura 4.1, no qual o volume de processo é relativamente baixo e as atividades podem ser modificadas durante o próprio processo de produção, em virtude da alta variedade do produto. Apesar disso, o número de situações imprevisíveis é pequeno e os recursos disponíveis para operação são compartilhados. 


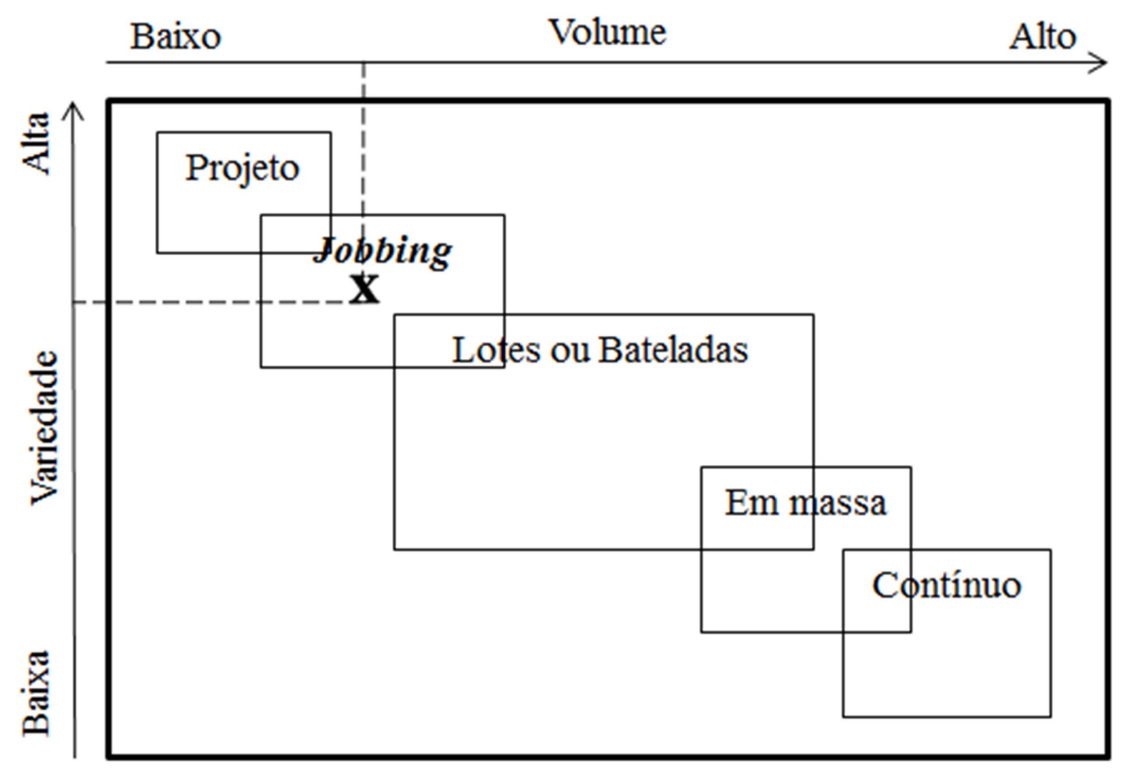

Figura 4.1 Processo de jobbing entre os tipos de processos por volume e variedade Fonte: Slack, Chambers e Johnston (2009)

Como o modelo proposto é para o estágio inicial de um processo de desenvolvimento, implementação e aprimoramento, ele não determina que os centros de reaproveitamento sejam especializados em algum tipo restrito de veículos leves, seja por marca, modelo ou ano de fabricação. Entretanto, é importante comentar que a redução na variedade dos veículos pode exigir menor flexibilidade do processo, o que pode conduzí-lo ao processo por lotes ou bateladas e à possível redução do custo da operação.

Além disso, a especialização pode impulsionar o posicionamento do centro de reaproveitamento dentro do mercado, principalmente no que diz respeito ao atendimento das necessidades dos clientes, que normalmente procuram peças usadas de um tipo específico de veículo leve. Dessa maneira, acredita-se que em estágios mais evoluídos as unidades produtivas devem buscar a especialização.

Nesse contexto, é interessante que a especialização seja definida tendo em vista a demanda existente e, se houver possibilidade, que ela seja discutida conjuntamente entre os centros de reaproveitamento do Distrito Federal. Dessa maneira, a demanda será ainda melhor atendida pelo mercado de peças reaproveitadas e eles serão cada vez menos concorrentes diretos, fato que pode aumentar a cooperação, atualmente pouco observada entre eles.

\subsection{DESCRIÇÃO DO PROCESSO DE REAPROVEITAMENTO}

Essa seção faz a proposta das oito atividades para o processo de reaproveitamento de veículos leves em fim de vida útil a ser implementado no Distrito Federal - aquisição, 
recebimento, liberação, despoluição, desmontagem, análise técnica da qualidade, armazenamento e saída. Elas e o relacionamento entre elas são ilustrados pela Figura 4.2.

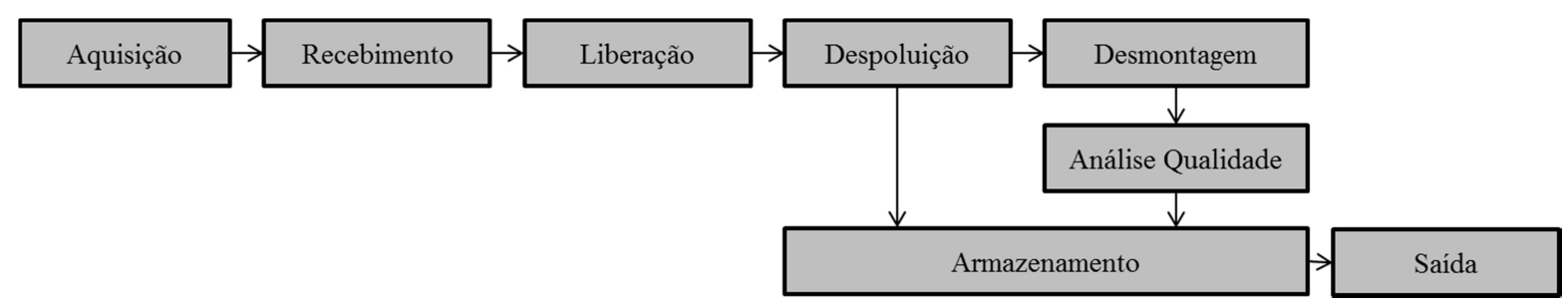

Figura 4.2 Descrição do processo de reaproveitamento de veículos em fim de vida útil

Observa-se que o processo de reaproveitamento proposto fragmentou a etapa de coleta em: aquisição, recebimento e liberação. A justificativa para essa decisão ocorre pelo fato de a coleta, normalmente, caracterizar apenas a entrada do veículo no centro e pelas atividades de aquisição e de liberação serem muito marcantes para a realidade do Distrito Federal e para a legislação brasileira.

A aquisição é a atividade através da qual o centro de reaproveitamento se prepara para obter ativamente a sua matéria-prima. Em países como os da União Européia, o governo disponibiliza aos últimos proprietários meios para que possam entregar o veículo numa instalação autorizada. Por outro lado, na experiência da Renova Ecopeças em São Paulo, em virtude da relação com a Porto Seguros, todos os veículos sinistrados são diretamente encaminhados para a instalação. Nessas realidades, citadas pela seção 3.2, de fato basta ao centro de reaproveitamento receber o produto, diferentemente das unidades do Distrito Federal.

Já a liberação foi apartada por envolver uma tarefa bastante reforçada pela Lei 12.977/ 2014 e que pode impactar diretamente no tempo total de transformação do veículo em fim de vida em peças reutilizáveis e não reutilizáveis, que é a emissão do Certificado de Baixa de Veículo pelo órgão executivo de trânsito, obrigatória para a continuidade das atividades de reaproveitamento.

Em seguida, as atividades de despoluição e desmontagem preparam e executam, respectivamente, a transformação dos veículos em peças ou conjunto de peças. Nelas, as principais boas práticas foram consideradas com intuito principal de fomentar e orientar uma estruturação sequencial de tarefas sem engessar a operação, já que não é possível alcançar o nível de procedimento operacional padrão dada a variedade de veículos. 
Na mesma linha de raciocínio, a análise técnica da qualidade foi inserida como atividade responsável por instituir o método na classificação de uma peça como reutilizável, não reutilizável ou passível de reutilização. Isso porque no diagnóstico realizado observou-se que essa definição costuma depender apenas da experiência dos funcionários, sem prévio levantamento de requisitos de qualidade para reutilização, das verificações capazes de atestá-los e dos níveis de aceitação de cada uma das peças.

Por fim, as atividades de armazenamento e saída finalizam o processo de reaproveitamento proposto, com a adequada estocagem dos materiais desmontados por determinado período e o encaminhamento das peças para consumidores secundários ou para empresas capazes de realizarem as estratégias de gerenciamento definidas pela análise técnica da qualidade.

Nas próximas subseções, as atividades aqui brevemente explanadas são detalhadas em tarefas, ou seja, pacotes de trabalho que precisam ser realizados para que os objetivos de cada uma delas sejam alcançados.

\subsubsection{Aquisição}

Além dos veículos em idade avançada, a Resolução CONTRAN 611/ 2016 dispõe que outros também devem ser encaminhados necessariamente para reaproveitamento: veículos apreendidos por ato administrativo ou de polícia, quando inviável seu retorno à circulação; sinistrados classificados como irrecuperáveis ou de grande monta, apreendidos ou indenizados por seguradoras; e alienados pelos seus respectivos proprietários, em quaisquer condições.

Os veículos apreendidos por ato administrativo ou de polícia, bem como os sinistrados e indenizados por seguradoras são leiloados e, a partir do exposto pela Resolução CONTRAN 611/ 2016, apenas poderão participar desses leilões os centros de reaproveitamento registrados pelo órgão executivo de trânsito. Para obtenção do registro junto ao órgão executivo de trânsito do Distrito Federal (DETRAN-DF) será necessário apresentar documentações de habilitação jurídica e de regularidade fiscal, que podem ser identificadas na Resolução CONTRAN 611/ 2016.

Após a concessão do registro, o DETRAN-DF irá disponibilizar as informações cadastrais da empresa na internet e será emitido um documento padronizado e numerado, que deve ser exposto pelo empresário em local visível ao público no estabelecimento do centro de reaproveitamento, de acordo com a Lei 12.977/ 2014. 
Autorizado para aquisição, propõe-se que o centro de reaproveitamento faça o levantamento dos instrumentos de divulgação de leilões e venda de veículos para desmontagem e a identificação da frequência de atualização de cada um deles. Com esse conhecimento e registro, é possível se manter atualizado sobre os veículos disponíveis para compra no mercado.

Quando há a identificação de um potencial veículo a ser recebido, a empresa Renova Ecopeças faz uma análise técnica das documentações e das condições do veículo. A primeira análise deriva um documento com a quantidade e a qualidade das peças possivelmente reutilizáveis (Lista de Peças Possivelmente Reutilizáveis do Veículo), enquanto a segunda confirma a idoneidade do vendedor e do veículo.

O modelo acata a boa prática tendo em vista a grande preocupação da Lei 12.977/ 2014 com a rastreabilidade dos veículos desmontados e solicita que a análise seja registrada em documento próprio. Em caso de o veículo ser de outro estado, propõe-se que seja contratado um terceiro especializado para essa tarefa, como identificado no próprio diagnóstico feito com as empresas do Distrito Federal (seção 3.5.1).

Mesmo no caso de o veículo possuir boa condição e completude documental, a Associação Brasileira de Desmontagem e Reciclagem de Veículo (ADERA) sugere que o centro de reaproveitamento avalie a Lista de Peças Possivelmente Reutilizáveis do Veículo tendo em vista as suas peças disponíveis, o giro do seu estoque e o histórico de vendas que caracteriza a demanda da localidade.

Sendo a avaliação positiva, o centro de reaproveitamento deve adquirir o veículo para desmontagem, com atenção à forma de recebimento para que haja redução do custo de transporte e definição da data prevista de chegada. Esse alerta é importante principalmente nos casos de veículos em estados distintos, nos quais o custo e o tempo podem impactar substancialmente a viabilidade do veículo. Por isso, orienta-se que seja registrado um Contrato de Aquisição de Veículo. Por fim, a última tarefa da aquisição é justamente o acompanhamento do transporte do veículo até o centro de reaproveitamento, se necessário.

A Tabela 4.2 consolida as tarefas propostas pelo modelo para a atividade de aquisição de veículo para o centro de reaproveitamento de veículos em fim de vida útil. 
Tabela 4.2 Lista de tarefas para aquisição de veículos no centro de reaproveitamento

\begin{tabular}{|c|c|c|}
\hline \# & Tarefa & Observação \\
\hline 1 & $\begin{array}{l}\text { Registro do centro de reaproveitamento no } \\
\text { DETRAN-DF }\end{array}$ & Consultar a Resolução CONTRAN 611/ 2016 \\
\hline 2 & $\begin{array}{l}\text { Levantamento dos instrumentos de divulgação } \\
\text { de leilão e venda de veículo }\end{array}$ & \\
\hline 3 & $\begin{array}{l}\text { Identificação da frequência de atualização dos } \\
\text { instrumentos levantados }\end{array}$ & \\
\hline 4 & Análise da documentação do veículo & $\begin{array}{l}\text { Com veículo em estado distinto, contratar } \\
\text { terceiro especializado para realização da tarefa } \\
\text { Resultado é a Lista de Peças Possivelmente } \\
\text { Reutilizáveis }\end{array}$ \\
\hline 5 & Análise técnica das condições do veículo & $\begin{array}{l}\text { Com veículo em estado distinto, contratar } \\
\text { terceiro especializado para realização da tarefa }\end{array}$ \\
\hline 6 & $\begin{array}{l}\text { Avaliação da Lista de Peças Possivelmente } \\
\text { Reutilizáveis com relação às peças } \\
\text { disponíveis, ao giro de estoque e às vendas }\end{array}$ & \\
\hline 7 & Aquisição do veículo & $\begin{array}{l}\text { Negociar a forma de recebimento do veículo, } \\
\text { para redução do custo de transporte (Contrato } \\
\text { de Aquisição de Veículo) }\end{array}$ \\
\hline 8 & $\begin{array}{l}\text { Acompanhamento do transporte do veículo } \\
\text { adquirido até o centro de reaproveitamento }\end{array}$ & \\
\hline
\end{tabular}

Para estágios posteriores do modelo e, especificamente, para aprimoramento da atividade de aquisição, é importante fazer duas colocações sobre a demanda para reaproveitamento de veículos em fim de vida útil que fogem ao escopo dos centros, mas que, se implementadas, podem fomentar os benefícios desse mercado e ainda alterar as tendências colocadas na seção 3.5.5.

A primeira delas diz respeito ao estabelecimento de procedimentos que proporcionem maior celeridade aos processos judiciais e policiais no sentido de liberar os veículos apreendidos para leilão, seja para circulação ou para sucata. Atualmente, em virtude do volume de veículos estocados nos pátios das instituições, bem como das precárias condições de armazenamento disponíveis, é comum que os veículos percam o seu valor durante o tempo em que permanecem bloqueados. Assim, alguns dos impactos negativos do veículo em fim de vida útil não conseguem ser contornados.

Nesse contexto, em 2015, a Associação dos Juízes Federais do Brasil (AJUFE) discutiu e propôs ao Conselho Nacional de Justiça $(\mathrm{CNJ})$ sugestões de melhoria para administração e destinação dos bens apreendidos, a partir da análise das experiências de direito comparado, incluindo criação de órgão gestor, realização de leilão virtual, antecipação de destinação e alienação. Não há conhecimento posterior sobre ações de continuidade dessas medidas.

A segunda colocação diz respeito à implementação de um Programa de Renovação de Frota, com incentivos para que os veículos com idade avançada saiam de circulação para 
serem reaproveitados e sejam trocados por veículos mais novos. Na Espanha experimentou-se um plano, de 2005 a 2010, no qual o usuário que apresentasse, na revendedora, o Certificado de Entrega de um veículo de idade avançada a um centro de reaproveitamento recebia um desconto na compra de um novo veículo (CNT, 2010).

No Brasil, em 2009 foi entregue ao governo pela Confederação Nacional do Transporte (CNT) o plano de Renovação de Frota de Caminhões (RenovAR), que tinha como objetivo melhorar o acesso ao crédito para redução da poluição emitida e destinação correta dos veículos pesados antigos. Rezende (2012) faz contribuições relevantes sobre esse assunto.

Em relação a veículos leves, foi divulgado por Gontijo (2016) a discussão entre a Federação Nacional de Distribuição de Veículos Automores (Fenabrave) e o Ministério do Desenvolvimento, Indústria e Comércio Exterior no sentido de implementar um programa similar ao espanhol com foco de retirar de circulação, gradativamente, veículos com mais de 15 anos. Complementarmente, entende-se que o aumento do Imposto sobre a Propriedade de Veículos Automotores (IPVA) para veículos com mais de 15 anos é uma iniciativa que tem sido implantada pelos estados e que pode contribuir nesse sentido.

\subsubsection{Recebimento}

O modelo propõe que a atividade de recebimento seja iniciada com a verificação do veículo e da sua documentação em relação à aquisição realizada no momento da chegada do veículo adquirido, inclusive com a conferência do Contrato de Aquisição de Veículo e da Lista de Peças Possivelmente Reutilizáveis. Sohn e Park (2014) colocam que é importante realizar essa comparação como uma espécie de checklist para posteriormente utilizá-la no planejamento da desmontagem (seção 3.2). No modelo, é proposta a Ficha de Recebimento de Veículo para exercício dessa finalidade.

Em caso de haver alguma variação inesperada, essa tarefa, que deve ser realizada ainda na área exterior ao centro de reaproveitamento, permite que o centro de reaproveitamento discuta com o vendedor e/ou com o terceiro especializado sobre as condições e documentações do veículo combinadas previamente. Em seguida, o veículo com verificação aprovada deve ser movimentado para o estoque de veículos, para continuidade das tarefas.

Então, o centro de reaproveitamento deve emitir a nota fiscal de entrada do veículo, conforme determina a Lei 12.977/ 2014. O modelo orienta que isso seja feito 
eletronicamente em virtude de consideração feita na legislação e, também, para facilitar a comunicação com os demais sistemas de informação que devem ser utilizados pelo centro.

Com registro formal do recebimento do veículo no centro de reaproveitamento que é a emissão da nota fiscal de entrada, a Resolução CONTRAN 611/ 2016 determina que o veículo seja vinculado a uma cartela de etiquetas de rastreabilidade, que posteriormente serão colocadas nas peças separadas do veículo para que cada uma delas tenha a informação sobre todas as etapas do processo de reaproveitamento, bem como do veículo do qual foram retiradas.

Em seguida, os dados da documentação do veículo, da aquisição concretizada, da nota fiscal emitida e da cartela de rastreabilidade devem ser inseridas no sistema de informação no prazo de até cinco dias corridos da entrada do veículo no centro de reaproveitamento, de acordo com a proposta da Lei 12.977/ 2014 e da Resolução CONTRAN 611/ 2016.

Complementarmente, a Diretiva 2000/53/CE e Cruz-Rivera (2008) são enfáticos no sentido de que o centro de reaproveitamento deve emitir um Certificado de Destruição para o último proprietário do veículo. Em ambos os contextos (seção 3.2), o documento é visto como uma exigência para cancelamento do registro do veículo pelo órgão competente e como uma necessidade para organização do sistema de reaproveitamento.

No Brasil, a Resolução CONTRAN 11/ 1998, que estabelece os critérios para a baixa de registro de veículos, determina que os documentos do veículo, as partes de chassi que contêm o registro VIN e suas placas sejam recolhidos ao órgão executivo de trânsito responsável pela sua baixa, que emite o Certificado de Baixa de Veículo mediante quitação de débitos fiscais e de multas de trânsito e ambientais vinculadas ao veículo.

Sendo assim, tendo em vista o estágio inicial no qual se encontra o modelo proposto, ele não absorve a emissão do Certificado de Destruição como uma boa prática para não aumentar o número de documentos necessários. Entretanto, considera-se que, em estágios posteriores, quando para baixa de veículo com idade avançada for obrigatória a entrega em centro de reaproveitamento, como propõe Cruz-Rivera (2008), e em caso de Programa de Renovação de Frota, para que seja liberado o crédito no novo veículo, ela pode vir a ser uma tarefa necessária e interessante. 
Basta, portanto, que o centro de reaproveitamento faça a solicitação do Certificado de Baixa de Veículo no prazo de até cinco dias corridos desde o recebimento de veículo, conforme determina a Lei 12.977/2014, para o órgão executivo de trânsito estadual ou do Distrito Federal, a depender do registro do veículo. Sendo assim, propõe-se que, em caso de o veículo adquirido em outro estado ainda não possuir Certificado de Baixa, que ele seja solicitado pelo terceiro contratado para adquirí-lo e embarcá-lo.

Pode ocorrer de o veículo adquirido já possuir Certificado de Baixa de Veículo. Se isso ocorrer, basta desconsiderar as tarefas que o abordam e dar continuidade às seguintes. A Tabela 4.3 consolida as tarefas propostas pelo modelo para a atividade de recebimento de veículo para o centro de reaproveitamento de veículos em fim de vida útil.

Tabela 4.3 Lista de tarefas para recebimento de veículos no centro de reaproveitamento

\begin{tabular}{|c|c|c|}
\hline \# & Tarefa & Observação \\
\hline 1 & $\begin{array}{l}\text { Verificação do veículo recebido e da sua } \\
\text { documentação em relação à aquisição feita }\end{array}$ & \\
\hline 2 & $\begin{array}{l}\text { Movimentação do veículo para estoque de } \\
\text { veículos }\end{array}$ & \\
\hline 3 & Emissão de nota fiscal de entrada do veículo & $\begin{array}{l}\text { Utilizar a nota fiscal eletrônica, dado que ela é } \\
\text { disponibilizada no Distrito Federal }\end{array}$ \\
\hline 4 & $\begin{array}{l}\text { Vinculação do veículo a uma cartela de } \\
\text { etiquetas de rastreabilidade }\end{array}$ & \\
\hline 5 & $\begin{array}{l}\text { Inclusão das informações iniciais do veículo } \\
\text { no sistema de informação }\end{array}$ & \\
\hline 6 & $\begin{array}{l}\text { Solicitação do Certificado de Baixa de } \\
\text { Veículo para o órgão executivo de trânsito }\end{array}$ & $\begin{array}{l}\text { Observar o órgão executivo de trânsito } \\
\text { adequado tendo em vista o registro do veículo }\end{array}$ \\
\hline
\end{tabular}

Propõe-se que essas tarefas sejam realizadas para veículos recebidos após a implementação das orientações realizadas. Por outro lado, para peças de veículos já existentes nos centros de reaproveitamento, a Resolução CONTRAN 611/ 2016 exige que seja apresentado, perante o DETRAN-DF, o inventário e os comprovantes da origem de aquisição das referidas peças, devendo submetê-las às etiquetas de rastreabilidade específicas (avulsas).

\subsubsection{Liberação}

A atividade de liberação inicia logo após o recebimento ter solicitado o Certificado de Baixa de Veículo ao órgão executivo de trânsito e encerra quando o centro de reaproveitamento o obtém como autorização para continuidade das atividades. Entretanto, entre esses dois eventos existe um intervalo de tempo, que é justamente o prazo do órgão executivo de trânsito para processamento do documento. 
Dessa forma, propõe-se que, enquanto o centro de reaproveitamento aguarda a emissão do Certificado de Baixa de Veículo, seja elaborado um Plano de Despoluição e Desmontagem do Veículo específico, tendo em vista que a variedade de marcas, modelos, ano de fabricação, acessórios, condições de circulação e manutenção, bem como a indisponibilidade de dados no contexto analisado, dificultam o prévio entendimento detalhado sobre o que deve ser realizado.

O Plano de Despoluição e Desmontagem do Veículo considera a Lista de Peças Possivelmente Reutilizáveis do Veículo, elaborada na atividade de aquisição e atualizada no recebimento, e as orientações feitas por esse modelo para as atividades de despoluição e desmontagem, a fim de ajustar cada uma das tarefas de acordo com as necessidades do veículo. É importante que esse Plano de Desmontagem do Veículo seja realizado pelo responsável técnico do centro de reaproveitamento.

Sobre o prazo para emissão do Certificado de Baixa do Veículo, não foi estabelecido um limite para o DETRAN-DF. Nesse sentido, foi levantada, no diagnóstico feito junto às empresas de reaproveitamento do Distrito Federal, uma preocupação sobre o longo tempo destinado a essa tarefa. Portanto, é necessário que sejam coletados dados, na implementação do estágio inicial do modelo, sobre o cumprimento dos prazos para que ele atenda às expectativas das empresas.

Por fim, dada a obtenção do Certificado de Baixa de Veículo, o centro de reaproveitamento deve arquivá-lo fisicamente por 10 anos, conforme a Lei 12.977/ 2014, e atualizar o registro do veículo no sistema de informação para que seja encerrada a liberação. A Tabela 4.4 consolida as tarefas propostas pelo modelo para a atividade de liberação de veículo para o centro de reaproveitamento de veículos em fim de vida útil.

Tabela 4.4 Lista de tarefas para liberação de veículos no centro de reaproveitamento

\begin{tabular}{l|l|l}
\hline$\#$ & Tarefa & Observação \\
\hline 1 & $\begin{array}{l}\text { Elaboração de Plano de Despoluição e } \\
\text { Desmontagem específico para o veículo }\end{array}$ & $\begin{array}{l}\text { Alocar o responsável técnico do centro de } \\
\text { reaproveitamento para essa tarefa }\end{array}$ \\
\hline 2 & $\begin{array}{l}\text { Obtenção do Certificado de Baixa de Veículo } \\
\text { no órgão executivo de trânsito }\end{array}$ & $\begin{array}{l}\text { Arquivar o Certificado de Baixa de Veículo } \\
\text { fiscamente por 10 anos no centro }\end{array}$ \\
\hline 3 & $\begin{array}{l}\text { Atualização do registro do veículo no sistema } \\
\text { de informação }\end{array}$ & \\
\hline
\end{tabular}

\subsubsection{Despoluição}

A Lei 12.977/ 2014 não explicita formalmente a atividade de despoluição. Por outro lado, a Resolução CONTRAN 611/ 2016, apesar de não aprofundar no assunto, estabelece que o 
centro de reaproveitamento remova e manipule os materiais com potencial lesivo ao meio ambiente. Por essa exigência e, também, porque a despoluição é uma atividade amplamente discutida na literatura como essencial para a redução dos impactos ambientais e para a qualidade dos produtos originados do reaproveitamento de veículos em fim de vida útil, ela é descrita pelo modelo proposto.

Primeiramente, a orientação é que o centro movimente o veículo para a área de despoluição e realize a lavagem da parte externa do veículo e da parte interna do capô, para que sejam retirados os resíduos superficiais. A partir do diagnóstico realizado com as empresas do Distrito Federal, observa-se que o uso de vaporizador d'água é mais eficiente na qualidade da limpeza que mangueiras tradicionais.

Em seguida, propõe-se que a despoluição seja realizada de acordo com a relação estipulada por Cruz-Rivera (2008) (seção 3.4.1), tendo em vista que ela contempla os materiais amplamente citados pelos demais autores e considera um estágio inicial de implementação dessa atividade dentro dos centros de reaproveitamento: baterias, combustível, óleo do motor, líquido de arrefecimento do motor, fluido do limpador de para-brisa, fluido de freio, fluido de transmissão, fluido da direção e fluido dos eixos.

Sohn e Park (2014) comentam (seção 3.4.1) que a suspensão do veículo com auxílio de um elevador de automóveis facilita a remoção de alguns dos materiais. Sendo assim, a sugestão é aceita e propõe-se que ela seja adotada como prática. Além disso, comenta-se que os recipientes de coleta precisam ser separados e adequados para o armazenamento dos fluidos, até que haja volume suficiente para o encaminhamento à empresa especializada.

Também nesse momento, orienta-se que as rodas e os pneus do veículo sejam retirados para impedir que o veículo volte a circular dentro do prazo de 10 dias estipulado pela Lei 12.977/ 2014. Isso porque, tendo em vista que ainda não há dados disponíveis sobre o tempo de despoluição e desmontagem, o modelo propõe que isso seja feito logo no começo, para evitar descumprimento da legislação. Em estágios posteriores, isso pode ser reformulado.

Afirmar que a retirada das rodas e dos pneus do veículo impede que o veículo volte a circular é questionável. Entretanto, tento em vista que a Lei 12.977/ 2014 é vaga na sua determinação e que o DETRAN-SP, primeiro órgão executivo de trânsito a fiscalizar o seu cumprimento, aceita essa iniciativa, orienta-se dessa forma em virtude da facilidade para 
que isso seja feito na despoluição sem que haja complicação com a atividade de desmontagem.

Ajustes podem ser necessários na listagem padrão a depender do veículo e, por isso, é importante que o colaborador tenha em mãos o Plano de Despoluição e Desmontagem do Veículo, no qual pode observar as orientações e os comentários colocados pelo responsável técnico do centro de reaproveitamento.

Materiais complementares são citados por diferentes autores, como os fluidos do sistema de ar condicionado, os repositórios dos fluidos, materiais explosivos e com mercúrio. Alguns deles foram tratados nesse modelo dentro das atividades de desmontagem e os demais ficarão como possibilidades para estágios posteriores, quando os centros estiverem maduros para aprimoramento da despoluição.

Por fim, o modelo propõe que o veículo seja movimentado para o estoque de veículos, se o veículo não for ser desmontado logo após. Entretanto, ele reforça que a intenção deve ser a de os veículos passarem da despoluição imediatamente para a desmontagem, com formação de estoque de peças, ao invés de estoque de veículos. De toda forma, pode ser que a aquisição tenha sido realizada por lote e, por isso, forme uma fila. Caso ele vá direto pra a desmontagem, esta atividade é que fará a movimentação.

Por fim, deve ser feita a atualização do registro do veículo no sistema de informação com a descrição dos materiais coletados, os seus respectivos volumes e o tempo necessário para realização da atividade. A Tabela 4.5 consolida as tarefas propostas pelo modelo para a atividade de despoluição de veículo para o centro de reaproveitamento de veículos em fim de vida útil.

Tabela 4.5 Lista de tarefas para despoluição de veículos no centro de reaproveitamento

\begin{tabular}{|c|c|c|}
\hline \# & Tarefa & Observação \\
\hline 1 & $\begin{array}{l}\text { Movimentação do veículo para área de } \\
\text { despoluição }\end{array}$ & \\
\hline 2 & $\begin{array}{l}\text { Lavagem da parte externa do veículo e da } \\
\text { parte interna do capô }\end{array}$ & $\begin{array}{l}\text { Utilizar vaporizador de água para melhor } \\
\text { qualidade da lavagem }\end{array}$ \\
\hline 3 & $\begin{array}{l}\text { Remoção dos materiais indicados na lista } \\
\text { proposta por Cruz-Rivera (2008) }\end{array}$ & 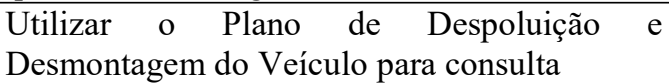 \\
\hline 4 & $\begin{array}{l}\text { Remoção das rodas e dos pneus do veículo } \\
\text { para impedimento da circulação em até } 10 \\
\text { dias }\end{array}$ & \\
\hline 5 & $\begin{array}{l}\text { Movimentação do veículo para área de } \\
\text { estoque de veículos, se necessário }\end{array}$ & \\
\hline 6 & $\begin{array}{l}\text { Atualização do registro do veículo no sistema } \\
\text { de informação }\end{array}$ & \\
\hline
\end{tabular}


No que diz respeito à despoluição, a Diretiva 2000/53/ CE orienta que os centros de reaproveitamento dos Estados-Membros utilizem sistemas de gestão ambiental certificados, como, por exemplo, a ISO 14.001: 2015, no desempenho das suas atividades (seção 3.4.1). Em virtude do estágio inicial da proposição, essa sugestão ficará para aprimoramentos posteriores.

\subsubsection{Desmontagem}

Como dito anteriormente (seção 3.4.1), poucos são os autores que definem uma sequência mais adequada para as tarefas da desmontagem visto que elas podem sofrer diferenças a depender do veículo e dos recursos disponíveis no centro de reaproveitamento. Por esse motivo, o modelo propõe o Plano de Despoluição e Desmontagem do Veículo, elaborado na atividade de liberação.

Cruz-Rivera (2008), Berzi et al. (2013) e Sohn e Park (2014) são os que mais se aproximam de um ordenamento ótimo, de acordo com a seção 3.4.1. Complementarmente, a experiência implementada pela Renova Ecopeças, no estado de São Paulo, também demonstra uma tentativa de sequenciamento que otimize o processo de desmontagem.

Propõe-se, portanto, uma combinação das boas práticas levantadas, com ênfase para as da Renova Ecopeças em virtude de a sua sequência ser amigável (de fora pra dentro), de estar compatível com a legislação brasileira e de possuir maior abrangência em relação às demais referências, mesmo assim, ajustes são feitos tendo em vista a realidade das empresas do Distrito Federal. Ela deve orientar a elaboração do Plano de Despoluição e Desmontagem do Veículo, conforme dito anteriormente (seção 4.3.3).

Primeiramente, o centro de reaproveitamento deve verificar se o veículo a ser desmontado se encontra no estoque de veículos ou na área de despoluição. Independentemente do local, ele deve ser movimentado para a área de desmontagem e, então, deve ser iniciada a desmontagem com a retirada das peças externas relacionadas à carroceria (capô, tampa traseira, porta, para-choque, para-lama, grade, retrovisor, lanterna e farol). Essa tarefa contempla integralmente a estação 1 e parcialmente a estação 2 de Sohn e Park (2014), ilustradas na Figura 3.5 .

A outra parte da estação 2 proposta por Sohn e Park (2014) é contemplada na terceira tarefa proposta, a qual diz respeito à remoção dos itens de tapeçaria do veículo (forração 
para assoalho e teto, estofamento do assento, forro das portas). Os cintos de segurança devem ser retirados nessa etapa, entretanto, reforça-se que eles compõem a lista de itens de segurança da Resolução CONTRAN 611/ 2016.

A remoção dos vidros das janelas do veículo é a tarefa subsequente e atende à exigência de Cruz-Rivera (2008). Nesse momento, a depender da estratégia de gerenciamento dos vidros do veículo, o vidro de segurança que contém a gravação da numeração de chassi deve ser separado porque é também item de segurança.

Então, a proposição do modelo segue para a remoção dos componentes mecânicos (bloco do motor, cabeçote, caixa de marcha, caixa de tração, cardã, carter, diferencial dianteiro e traseiro, intercooler/ compressor, compressor e condensador do ar condicionado, módulo de câmbio automático, radiador de água, turbina, volante do motorista sem airbag) incluída na estação 3 e na estação inclinada de Sohn e Park (2014). Esses componentes mecânicos representam grande parte das peças de rastreabilidade obrigatória pela Resolução CONTRAN 611/ 2016.

A sexta tarefa da desmontagem refere-se à remoção dos demais itens de segurança, que não poderão ser destinados à reutilização, independentemente da condição em que se encontrem. A Resolução CONTRAN 611/ 2016 também considera os seguintes itens como de segurança: as peças de suspensão, o sistema de freios, o sistema de controle de estabilidade, o sistema de direção e o sistema de airbags. Eles possuem destinação restrita à reciclagem ou ao tratamento de resíduos.

Sobre o sistema de airbags é curioso comentar que diferentemente do encontrado na pesquisa feita por Berzi et al. (2013), na Itália, comentada na seção 3.4.1, o diagnóstico com as empresas do Distrito Federal mostra que esse material é removido pelos centros existentes na localidade. Basta, portanto, definir a melhor estratégia para gerenciamento, de acordo com as limitações impostas pela lei.

Em seguida, o modelo propõe que sejam retirados os componentes elétricos e eletrônicos (capa do painel, comandos limpador/ luzes/ setas, painel de instrumentos, módulo de injeção eletrônica, motor de arranque, alternador, imobilizador). Cruz-Rivera (2008) reforça que nessa tarefa precisam ser retiradas as fiações, as quais possuem alto valor econômico no mercado, mas que consomem tempo (BERZI et al., 2013). O modelo deixa a 
possibilidade de elas serem removidas para que haja dados disponíveis para posteriores análises sobre o seu benefício, mas não faz exigência nesse sentido.

A tarefa nove, chamada pela Renova Ecopeças de recorte do monobloco, pode ser considerada um tipo de desmontagem destrutiva, na qual o painel do teto, painel frontal, as laterais e o assoalho do veículo são recortados e/ou prensados para redução de volume, visto que, por serem elementos estruturais do veículo, não podem ser reutilizáveis e devem ser encaminhados para reciclagem. O modelo adota essa tarefa apenas quando há disponibilidade do equipamento.

Por fim, o centro de reaproveitamento deve atualizar o registro do veículo no sistema de informação com os dados de realização e de encerramento da desmontagem. A Lei 12.977/ 2014 determina um prazo de até três dias para essa tarefa. A Tabela 4.6 consolida as tarefas propostas pelo modelo para a atividade de desmontagem de veículo para o centro de reaproveitamento de veículos em fim de vida útil.

Tabela 4.6 Lista de tarefas para desmontagem de veículos no centro de reaproveitamento

\begin{tabular}{l|l|l}
\hline$\#$ & Tarefa & Observação \\
\hline 1 & $\begin{array}{l}\text { Movimentação do veículo para área de } \\
\text { desmontagem }\end{array}$ & $\begin{array}{l}\text { Observar se o veículo já não se encontra no } \\
\text { local }\end{array}$ \\
\hline 2 & $\begin{array}{l}\text { Desmontagem das peças externas relacionadas } \\
\text { à carroceria do veículo }\end{array}$ & \\
\hline 3 & Remoção dos itens de tapeçaria do veículo & $\begin{array}{l}\text { Atentar-se ao vidro que contém a numeração } \\
\text { do chassi do veículo }\end{array}$ \\
\hline 4 & Remoção dos vidros do veículo & $\begin{array}{l}\text { Remoção dos componentes mecânicos do } \\
\text { veículo }\end{array}$ \\
\hline 5 & $\begin{array}{l}\text { Remoção dos demais itens de segurança do } \\
\text { veículo }\end{array}$ & $\begin{array}{l}\text { Remoção dos componentes elétricos e } \\
\text { eletrônicos }\end{array}$ \\
\hline 7 & Recorte do monobloco ou chassi carroceria & \\
\hline 9 & $\begin{array}{l}\text { Atualização do registro do veículo no sistema } \\
\text { de informação }\end{array}$ & \\
\hline
\end{tabular}

Zhao e Chen (2011) e Berzi et al. (2013) reforçam a preferência para realização da desmontagem manual em algumas das tarefas propostas. $\mathrm{O}$ argumento é que a delicadeza humana preserva em maior grau a qualidade do material, melhorando a possibilidade de reutilização. No contexto, Tian e Chen (2016) reforçam que mesmo as empresas com alto custo em virtude da desmontagem manual obtêm lucros. De toda forma, tendo em vista o estágio de implementação do modelo não seria viável propor um processo automatizado. 
Sendo assim, a orientação para participação intensiva de recursos humanos na desmontagem fica confirmada.

Ao final desta atividade, o modelo prevê que o veículo esteja totalmente desmontado. Provavelmente as tarefas 2, 3, 4, 5 e 7 resultaram em partes potencialmente reutilizáveis. Por outro lado, no caso dos itens de segurança, dos elementos estruturais do veículo e de peças em péssimas condições, já se tem o conhecimento de que não serão reutilizáveis. De toda forma, elas todas são encaminhadas para análise da qualidade, atividade que será descrita a seguir.

\subsubsection{Análise Técnica da Qualidade}

A análise técnica é a atividade que decide qual a estratégia de gerenciamento que será adotada para cada um dos materiais removidos do veículo em fim de vida útil. Para que essa deliberação ocorra, é necessário conhecer os requisitos de qualidade para reutilização, as verificações capazes de atestá-los e os níveis de aceitação de cada uma das peças.

Nesse sentido, a Lei 12.977/ 2014 responsabiliza o CONTRAN por prever em suas normas essas informações. Entretanto, ele ainda não as divulgou, mas apenas apresentou a lista dos itens de segurança, conforme comentado na seção 4.3.5. Por isso, o modelo propõe que o centro de reaproveitamento, através do responsável técnico, faça uma breve definição para análise técnica da qualidade.

Feita essa consideração, ele sugere que a análise técnica seja realizada após cada tarefa da desmontagem - roda e pneus; carroceria; tapeçaria; vidros; componentes mecânicos; itens de segurança; componentes elétricos e eletrônicos; monobloco. A opção por essa prática derivou de o espaço físico dos centros de reaproveitamento ser insuficiente para execução totalmente sequencial das atividades. Sendo assim, o colaborador deve obter os materiais já desmontados da atividade anterior e movimentá-los para a área adequada.

De posse das orientações do responsável técnico e com as peças alocadas na área da análise técnica, o centro de reaproveitamento deve iniciar os testes de verificação da qualidade. Obtidos os resultados, propõe-se que os materiais sejam classificados de acordo com a Resolução CONTRAN 611/ 2016: reutilizáveis, passíveis de reutilização e não reutilizáveis. A Renova Ecopeças as nomeia, respectivamente, de peças tipo A, B e C, entretanto o modelo preferiu manter a nomenclatura do CONTRAN para unicidade com o seu sistema. 
Encerrada a classificação, as peças reutilizáveis podem ser precificadas. Orienta-se que o centro de reaproveitamento estabeleça critérios para precificação dos produtos, tendo em vista os valores dos produtos novos, dos centros concorrentes, bem como dos custos envolvidos nas atividades de reaproveitamento.

Em seguida, as peças reutilizáveis e as não reutilizáveis podem ser etiquetadas. Nesse momento, o responsável técnico define a estratégia de gerenciamento a ser tomada e preenche a Ficha de Análise Técnica do Veículo, que visa facilitar a elaboração do Laudo Técnico ao final da atividade. Sohn e Park (2014) enfatizam a importância do registro das tarefas desempenhadas para melhor conhecimento do processo.

Por outro lado, nas peças passíveis de reutilização devem ser aplicadas as técnicas adequadas de renovação, reparação e recondicionamento, por orientação do responsável técnico. Pode ser que o centro de reaproveitamento prefira encaminhar a peça à outra empresa mais especializada, entretanto, o modelo orienta que essa decisão seja embasada em uma prévia avaliação de custo e benefício.

As peças renovadas, reparadas ou recondicionadas devem passar por novos testes de verificação da qualidade. Em caso de elas ainda não serem aprovadas, o centro de reaproveitamento pode tentar repetir a aplicação das técnicas, mas o modelo orienta que essa decisão seja embasada em uma prévia avaliação de custo e benefício.

Obtidos os resultados definitivos, as peças devem ser classificadas, precificadas (apenas as reutilizáveis) e etiquetadas de forma semelhante à explicada. O responsável técnico também define a estratégia de gerenciamento a ser tomada com as não reutilizáveis e complementa a Ficha de Análise Técnica do Veículo.

Nesse momento, é importante reforçar que, com exceção da primeira tarefa descrita, as demais anteriores serão repetidas para cada tarefa da desmontagem, conforme sugestão explicitada, até a finalização da desmontagem do veículo. Apenas em seguida, as próximas tarefas serão desenvolvidas.

Próximo do encerramento da atividade, o responsável técnico do centro, a partir da Ficha de Análise Técnica do Veículo preenchida pelo colaborador envolvido, deve elaborar os Laudos Técnico e Complementar com as informações definidas pela Resolução CONTRAN 611/ 2016 e disponibilizá-lo em até cinco dias após a desmontagem no sistema 
de informação, de acordo com a Lei 12.977/ 2014, atualizando o registro do veícul. A Tabela 4.7 consolida as tarefas propostas pelo modelo para a atividade de análise técnica da qualidade de peças.

Tabela 4.7 Lista de tarefas para análise técnica de peças no centro de reaproveitamento

\begin{tabular}{|c|c|c|}
\hline \# & Tarefa & Observação \\
\hline 1 & $\begin{array}{l}\text { Definição dos requisitos de qualidade para } \\
\text { reutilização, das verificações capazes de } \\
\text { atestá-los e os níveis de aceitação de cada uma } \\
\text { das peças }\end{array}$ & $\begin{array}{l}\text { Alocar o responsável técnico do centro de } \\
\text { reaproveitamento para essa tarefa } \\
\text { Após concluída, essa tarefa deve orientar as } \\
\text { análises da qualidade seguintes }\end{array}$ \\
\hline 2 & $\begin{array}{l}\text { Movimentação das peças já desmontadas para } \\
\text { a área de análise da qualidade }\end{array}$ & \\
\hline 3 & $\begin{array}{l}\text { Realização dos testes de verificação da } \\
\text { qualidade com as peças movimentadas }\end{array}$ & \\
\hline 4 & $\begin{array}{l}\text { Classificação das peças em: reutilizáveis, } \\
\text { passíveis de reutilização, não reutilizáveis }\end{array}$ & \\
\hline 5 & $\begin{array}{l}\text { Precificação das peças reutilizáveis de acordo } \\
\text { com critérios de precificação estabelecidos }\end{array}$ & $\begin{array}{l}\text { Realizar pesquisa de mercado para estabelecer } \\
\text { os critérios de precificação do centro }\end{array}$ \\
\hline 6 & $\begin{array}{l}\text { Etiquetagem das peças reutilizáveis e não } \\
\text { reutilizáveis }\end{array}$ & \\
\hline 7 & $\begin{array}{l}\text { Definição da estratégia de gerenciamento a ser } \\
\text { tomada para peças reutilizáveis e não } \\
\text { reutilizáveis }\end{array}$ & \\
\hline 8 & $\begin{array}{l}\text { Preenchimento da Ficha de Análise Técnica } \\
\text { do Veículo para peças reutilizáveis e não } \\
\text { reutilizáveis }\end{array}$ & \\
\hline 9 & $\begin{array}{l}\text { Aplicação das técnicas de renovação, } \\
\text { reparação e recondicionamento nas peças } \\
\text { passíveis de reutilização }\end{array}$ & $\begin{array}{l}\text { Realizar avaliação de custo e benefício antes } \\
\text { de encaminhar as peças a outras empresas }\end{array}$ \\
\hline 10 & $\begin{array}{l}\text { Realização de novos testes de verificação da } \\
\text { qualidade com as peças tratadas }\end{array}$ & $\begin{array}{l}\text { Realizar avaliação de custo e benefício antes } \\
\text { de repetir a aplicação das técnicas de } \\
\text { renovação, reparação e recondicionamento }\end{array}$ \\
\hline 11 & $\begin{array}{l}\text { Classificação das peças tratadas em: } \\
\text { reutilizáveis e não reutilizáveis }\end{array}$ & \\
\hline 12 & $\begin{array}{l}\text { Precificação das peças tratadas classificadas } \\
\text { como reutilizáveis }\end{array}$ & \\
\hline 13 & Etiquetagem das peças tratadas & \\
\hline 14 & $\begin{array}{l}\text { Definição da estratégia de gerenciamento a ser } \\
\text { tomada para peças tratadas }\end{array}$ & \\
\hline 15 & $\begin{array}{l}\text { Complementação da Ficha de Análise Técnica } \\
\text { do Veículo com peças tratadas }\end{array}$ & \\
\hline 16 & $\begin{array}{l}\text { Elaboração dos Laudos Técnico e Técnico } \\
\text { Complementar }\end{array}$ & \\
\hline 17 & $\begin{array}{l}\text { Atualização do registro do veículo no sistema } \\
\text { de informação }\end{array}$ & \\
\hline
\end{tabular}

De acordo com Sohn e Park (2014) a codificação das peças é importante para rastreabilidade das peças. No modelo proposto, a etiquetagem tem exatamente essa função, pois ela identifica a peça e, através de um código, dá informações sobre o veículo da qual foi retirada, bem como do processo de reaproveitamento pelo qual passou.

A Resolução CONTRAN 611/ 2016 padroniza uma etiqueta com número de série emitido pelo órgão executivo de trânsito do Distrito Federal. As especificações técnicas relativas ao 
material, ao holograma, ao texto, ao brasão estampado, entre outras, estão contidas nos anexos da própria Resolução. Sobre isso, ressalta-se que a Resolução CONTRAN 611/ 2016 determina a utilização da etiqueta apenas nos itens de segurança e nas peças de rastreabilidade obrigatória. Sendo assim, para atender às exigências da regulamentação, o centro de reaproveitamento não precisa etiquetar todas as peças.

Entretanto, essa prática não é a observada nos centros de reaproveitamento já registrados do estado de São Paulo. Para que haja padronização, rastreabilidade e controle de estoque em todas as peças, as experiências visitadas utilizam etiquetas semelhantes às do órgão executivo de trânsito também nas peças não obrigatórias. Essa abordagem foi adotada para transmitir confiabilidade aos consumidores do mercado, um dos objetivos do processo.

Inclusive, no que diz respeito ao consumidor, com a etiquetagem das peças, ele absorve o papel de crítico de fiscalizador dos centros de reaproveitamento, pois é capaz de averiguar a antecedência das peças usadas, dos veículos e do último proprietário. A leitura das informações ocorre por meio de uma ferramenta de código de resposta rápida (em inglês QR Code), disponível em smartphones.

Ademais da etiqueta imposta pela Resolução CONTRAN 611/ 2016, a Renova Ecopeças utiliza uma marcação de nanotecnologia própria. Ela não foi absorvida pelo modelo proposto tendo em vista o estágio inicial de maturidade dos centros, bem como em virtude do pequeno acréscimo de benefício que ela proporciona à rastreabilidade.

\subsubsection{Armazenamento}

Da mesma forma que a análise da qualidade em relação à desmontagem, o modelo sugere que o armazenamento seja realizado por etapas em relação à análise da qualidade, após cada grupo de peças ter sido verificado. Sendo assim, o colaborador deve obter as peças já etiquetadas para movimentá-las para a área adequada. As exceções são as peças retiradas na despoluição, que são encaminhadas diretamente para o armazenamento.

Nesse momento, todas as peças dividem-se em duas classificações - reutilizáveis e não reutilizáveis -, visto que as passíveis de reutilização já receberam tratamento na análise da qualidade e foram alocadas em uma das duas. Sendo assim, as peças reutilizáveis devem ser armazenadas no estoque para reúso, que deve ficar mais próximo da área de atendimento ao cliente. Com base na experiência das empresas do estado de São Paulo, 
sugere-se que ele seja organizado por tipo de peça, por marca e por modelo de veículo em corredores e prateleiras. A Figura 4.3 mostra uma representação da organização proposta.
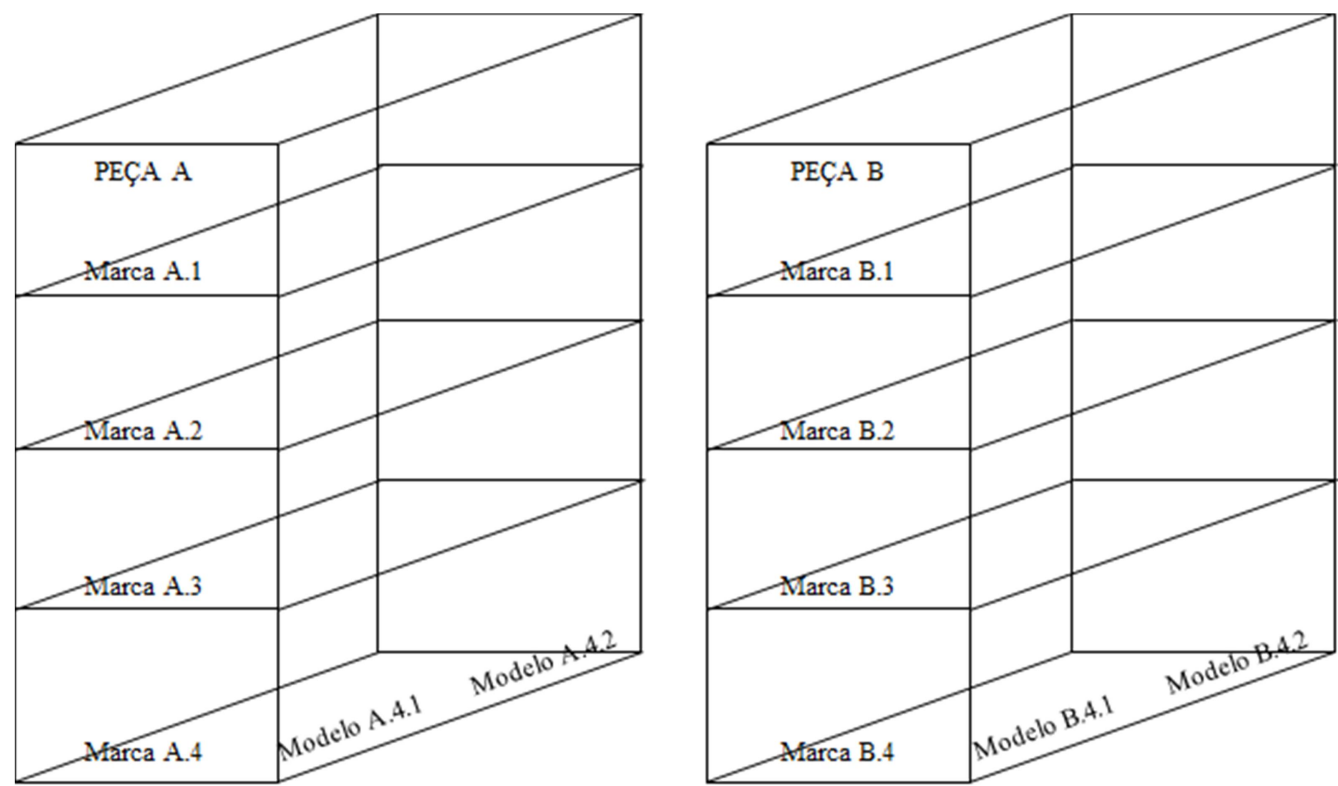

Figura 4.3 Representação da organização do estoque por tipo, marca e modelo de peça

Pode ser necessário alterar a altura, a largura e/ou a estrutura das prateleiras em virtude do tipo de peça que se deseja armazenar. Nesse sentido, orienta-se que o centro de reaproveitamento busque a menor ocupação de espaço físico sem que a qualidade da peça seja comprometida. Também pode ser que seja possível pendurar peças leves no teto. Se isso ocorrer, sugere-se que seja feito para melhor aproveitamento do espaço.

No que diz respeito às peças não reutilizáveis, o modelo sugere que elas sejam alocadas em diferentes grupos de estoque:

- Grupo 1: Itens de segurança, pneus e baterias. Esses materiais serão encaminhados para seus fabricantes, comerciantes ou empresas autorizadas por eles, tendo em vista as exigências da Lei 12.305/ 2010, da Lei 12.977/ 2014 e da Resolução CONAMA 401/ 2008. Apenas esses atores podem remanufaturar, reciclar ou fazer destinação final desses materiais e, por esse motivo, orienta-se que eles sejam organizados por fabricante.

- Grupo 2: Não reutilizáveis da despoluição para reciclagem. Os líquidos, fluidos e óleos da despoluição são diretamente encaminhados para recipientes adequados após a sua remoção dos veículos. Sendo assim, orienta-se que o estoque desse grupo fique próximo à área de despoluição e que seja separado por tipo de fluido. Em seguida, 
parte será encaminhada diretamente para empresas de reciclagem, enquanto outra parte pode ser também encaminhada para seus fabricantes, por respaldo da Lei 12.305/ 2010.

- Grupo 3: Não reutilizáveis para reciclagem. Esses materiais serão vendidos para empresas especializadas em reciclagem. O modelo sugere que eles sejam separados em plásticos, vidros e metais. Divisões mais específicas serão sugeridas para estágios posteriores de aprimoramento dos centros de reaproveitamento e, também, do mercado relacionado. Para esse grupo, pode ser que seja necessário realizar a trituração dos materiais antes da reciclagem. Se for o caso, considera-se que essa atividade é de responsabilidade da empresa recicladora.

- Grupo 4: Não reutilizáveis para destinação final. Os materiais que não possuem possibilidade de reaproveitamento ficam armazenados para destinação final adequada.

De acordo com a Lei $12.977 / 2014$, o limite para que encaminhamento dos estoques dos quatro grupos de materiais não reutilizáveis seja feito é de 20 dias úteis a contar da desmontagem do veículo. Por esse motivo, o modelo orienta que os centros de reaproveitamento calculem o tamanho desses espaços com base na capacidade média de desmontagem de 15 veículos por mês.

Por fim, propõe-se que seja feita a atualização do registro do veículo no sistema de informação, com indicação do endereço de armazenamento de cada uma das peças. Dessa maneira, um dos problemas levantados pelas empresas do Distrito Federal fica reduzido: a dificuldade de localização da peça em estoque no momento da venda. A Tabela 4.8 consolida as tarefas propostas pelo modelo para a atividade de armazenagem de veículo para o centro de reaproveitamento de veículos em fim de vida útil.

Tabela 4.8 Lista de tarefas para armazenagem de peças no centro de reaproveitamento

\begin{tabular}{l|l|l}
\hline$\#$ & Tarefa & Observação \\
\hline 1 & $\begin{array}{l}\text { Movimentação das peças reutilizáveis para os } \\
\text { locais de armazenamento adequados }\end{array}$ & \\
\hline 2 & $\begin{array}{l}\text { Movimentação das peças não reutilizáveis } \\
\text { para os locais de armazenamento adequados }\end{array}$ & $\begin{array}{l}\text { Calcular o tamanho do estoque de peças não } \\
\text { reutilizáveis considerando o giro de um mês }\end{array}$ \\
\hline 4 & $\begin{array}{l}\text { Atualização do registro do veículo no sistema } \\
\text { de informação }\end{array}$ & \\
\hline
\end{tabular}

Sobre a existência de empresas de reciclagem no Distrito Federal, os dados da Secretaria de Estado de Fazenda do Distrito Federal (SEF-DF) para as Classificações Nacional de Atividades Econômicas (CNAE) 3831-9/01 e 3831-9/99, que dizem respeito à recuperação de alumínio e outros materiais metálicos, indicam 131 empresas registradas. 
Talvez para os demais materiais a oferta de empresas seja menor e, então, será necessário, a partir dos dados coletados do volume gerado pelos centros de reaproveitamento, promover uma discussão junto às organizações de fomento no sentido de incentivar a vinda dessas empresas para a região. Em estágios posteriores do modelo essa possibilidade pode ser discutida, com envolvimento de todos os atores da cadeia de reaproveitamento, dado que a reciclagem é um processo que exige altos investimentos e que, em algumas localidades, ainda continua sem viabilidade econômica em virtude do baixo valor de alguns produtos no mercado (plástico, vidro, têxtil) (INGHELS et al., 2016).

Ademais, nesse momento, também devem ser consideradas as situações econômicas e geográficas da localidade na qual se encontra o centro de reaproveitamento (MANSOUR et al., 2010). Pode acontecer de não haver disponibilidade de empresa para implementação da estratégia ótima próximo à unidade de desmontagem. Nesse caso, a necessidade de transporte pode inviabilizar o tratamento e exigir que outra opção, menos eficiente, precise ser selecionada.

\subsubsection{Saída}

Como restrição da saída das partes e peças resultantes do processo de reaproveitamento, a Resolução CONTRAN 611/ 2016 determina que os centros possam comercializar apenas com consumidor ou usuário final, outra empresa igualmente registrada ou empresas do ramo de reciclagem e/ou recuperação de peças.

Os reutilizáveis dependem do interesse do comprador, usuário final ou empresa registrada, para que sejam vendidos. Assim, o modelo propõe que haja atendimento no local do próprio centro de reaproveitamento, pois muitos clientes gostam de conferir a peça usada pessoalmente antes de comprá-la, mas que também haja divulgação das peças em estoque em plataformas de e-commerce.

Essa prática é observada na Renova Ecopeças e também foi identificada em parte das empresas do Distrito Federal, com a justificativa de que o alcance é mais amplo. Considera-se que o centro obrigatoriamente terá acesso à internet para uso do sistema de informação do DETRAN-DF e, portanto, pode usufruir da mesma infraestrutura para promoção no e-commerce.

As peças não reutilizáveis ficam armazenadas com intuito de acumular volume que justifique o transporte. Entretanto, de acordo com a Lei 12.977/ 2014, o prazo para que o 
encaminhamento desses estoques seja feito é de 20 dias úteis a contar da desmontagem do veículo, ou seja, o transporte deve ser organizado mensalmente. O modelo propõe que, em caso de necessidade, para facilitar o preenchimento dos veículos transportadores, o centro de reaproveitamento coordene com as unidades próximas.

No que diz respeito ao preço de venda estipulado e às condições de retirada ou entrega, pode haver negociação. Nesse momento, orienta-se que o vendedor tenha conhecimento dos custos de transporte e da margem de lucro do produto.

A exceção à essa comercialização são as partes não reutilizáveis do grupo 4, que devem ser encaminhadas para a destinação final. Nessa situação, o centro de reaproveitamento contratará o serviço de coleta de material para entrega em local combinado. Essa necessidade foi identificada no Distrito Federal, tendo em vista a ausência de serviços públicos dessa natureza.

Confirmada a aquisição ou contratação, seja de peças reutilizáveis ou não reutilizáveis, para pessoas físicas ou jurídicas, o centro de reaproveitamento deve emitir a nota fiscal de saída com as informações de rastreabilidade estipuladas na Resolução CONTRAN 611/ 2016, bem como com as orientações adicionais de uso e condições de troca ou garantia da peça, se for o caso. Além disso, deve atualizar o registro dos dados da atividade no sistema de informação.

Ademais, quando a peça reutilizável for enviada/ despachada, o modelo propõe que seja feita uma embalagem adequada ao transporte, para que a qualidade do produto permaneça a mesma no local de destino. Se a retirada da peça for no próprio centro, a entrega é simplificada e não exige embalagem, para contenção de custos.

A Tabela 4.9 consolida as tarefas propostas pelo modelo para a atividade de saída de peças para o centro de reaproveitamento de veículos em fim de vida útil. 
Tabela 4.9 Lista de tarefas para saída de peças do centro de reaproveitamento

\begin{tabular}{l|l|l}
\hline$\#$ & Tarefa & Observação \\
\hline 1 & $\begin{array}{l}\text { Atendimento ao consumidor para peças } \\
\text { reutilizáveis }\end{array}$ & $\begin{array}{l}\text { Utilizar plataformas de e-commerce para } \\
\text { ampliar o alcance do atendimento }\end{array}$ \\
\hline 2 & $\begin{array}{l}\text { Fechamento do preço e das condições de } \\
\text { retirada ou entrega das peças reutilizáveis ou } \\
\text { não reutilizáveis (exceção grupo 4) }\end{array}$ & \\
\hline 3 & $\begin{array}{l}\text { Contratação do serviço de coleta de resíduos } \\
\text { para entrega em destinação final }\end{array}$ & \\
\hline 5 & $\begin{array}{l}\text { Emissão da nota fiscal de saída da peça } \\
\text { comercializada }\end{array}$ & \\
\hline 6 & $\begin{array}{l}\text { Atualização do registro do veículo no sistema } \\
\text { de informação }\end{array}$ & \\
\hline 7 & $\begin{array}{l}\text { Entrega de peças não reutilizáveis (grupo 4) às } \\
\text { empresas contratadas }\end{array}$ & \\
\hline 8 & $\begin{array}{l}\text { Entrega de peças vendidas com condição de } \\
\text { retirada no centro de reaproveitamento }\end{array}$ & \\
\hline 9 & $\begin{array}{l}\text { Envilagem de peças vendidas com condição } \\
\text { entrega no local de destino }\end{array}$ & \\
\hline
\end{tabular}

Complementarmente, tendo em vista a responsabilidade do centro de reaproveitamento em garantir que o material destinado à empresa de reciclagem não receba qualquer outro tipo de tratamento, orienta-se que seja realizada uma parceria com uma empresa específica de confiança. Assim, é possível, inclusive, melhorar as condições de coleta.

\subsection{CARACTERIZAÇÃO DOS RECURSOS HUMANOS}

No que diz respeito aos recursos humanos, o modelo explicita a importância de adequação do centro às regulações relacionadas, tendo em vista que a formalização dos trabalhadores é um dos impactos sociais positivos almejados da estruturação do sistema de gerenciamento de veículos em fim de vida útil. Sendo assim, as exigências da Lei 5.452/ 1943 - Consolidação das Leis do Trabalho (CLT) -, bem como as das normas de segurança e medicina do trabalho devem ser atendidas.

Nesse contexto, Slack, Chambers e Johnston (2009) consideram alguns elementos importantes para o projeto adequado do trabalho dos recursos humanos: condições ambientais, tecnologia disponível, tempo de duração das tarefas, quantidade de pessoas envolvidas, divisão do trabalho, método adequado e comprometimento da equipe.

Os dois primeiros elementos serão comentados em seções seguintes - infraestrutura e equipamentos, respectivamente. Sobre a mensuração do tempo para execução das tarefas, tendo em vista que no Distrito Federal não houve levantamento nesse sentido, o modelo faz considerações sobre a coleta de dados e o controle de informações em seção posterior. 
Sendo assim, considerando o estágio inicial do modelo proposto, ele faz considerações gerais sobre a quantidade e a capacitação de pessoas e sobre a divisão das tarefas, com base nas regulações específicas do tipo de processo e no diagnóstico realizado com as empresas locais. As futuras pesquisas que vierem a propor estágios posteriores poderão aprofundá-lo, complementá-lo e alterá-lo no que for considerado necessário.

\subsubsection{Quantidade e Capacitação dos Recursos Humanos}

No modelo, a capacidade de reaproveitamento dos centros foi mantida próxima da realidade existente, de 15 veículos mensais. A partir das mesmas considerações colocadas no início do capítulo, ele orienta que a quantidade de pessoas envolvidas também seja mantida em quatro colaboradores com o proprietário.

De acordo com a Resolução CONTRAN 611/ 2016, o centro de reaproveitamento precisa possuir um responsável técnico junto ao Conselho Regional de Engenharia e Agronomia (CREA) para exercício das funções colocadas na Resolução CONFEA 458/ 2001. Para os que não possuem uma graduação em engenharia, existem cursos técnicos em mecânica especializados na desmontagem de veículos.

Tendo em vista que os proprietários das empresas do Disitrito Federal já trabalham pessoalmente nos centros e que o curso técnico exige um investimento financeiro que não pode ser perdido em virtude da rotatividade dos colaboradores, o modelo propõe que o proprietário o faça.

Para os demais colaboradores, a Resolução CONTRAN 611/ 2016 apenas comenta sobre a capacitação técnica, mas não a restringe diretamente. $\mathrm{O}$ diagnóstico realizado no Distrito Federal deixou claro que conhecimento técnico tácito os colaboradores possuem, mas que dificilmente possuem uma formação acadêmica.

A Renova Ecopeças, por exemplo, tem um projeto de desenvolvimento técnico das pessoas que vivem próximo à sua unidade produtiva para que elas já iniciem a carreira profissional com capacitação. Uma iniciativa desse tipo, apesar de gerar impacto social interessante, exige alto investimento financeiro e pode não ser viável aos centros de reaproveitamento menores. Sendo assim, o modelo a valoriza, mas não a coloca como orientação para o estágio inicial proposto. Uma possibilidade é a transmissão do conhecimento adquirido no curso técnico pelo proprietário a pessoas selecionadas. 


\subsubsection{Divisão das Tarefas dos Recursos Humanos}

O modelo propõe a divisão das tarefas em quatro funções, cada qual com responsabilidades determinadas: administrativa, comercial, técnica e operacional. A Tabela 4.10 apresenta as principais tarefas de cada uma delas e, complementarmente, encontra-se no Apêndice B a lista completa das tarefas propostas com a alocação da função adequada.

Tabela 4.10 Descrição das principais tarefas da divisão de funções proposta

\begin{tabular}{l|l}
\hline \multicolumn{1}{c}{ Função } & Descrição das Principais Tarefas \\
\hline \multirow{3}{*}{ Administrativa } & $\begin{array}{l}\text { registro do centro de reaproveitamento; análise prévia da documentação do veículo; } \\
\text { verificação da documentação do veículo no recebimento; e registros de entrada e saída } \\
\text { do veículo no centro de reaproveitamento. }\end{array}$ \\
\hline \multirow{5}{*}{ Técnica } & $\begin{array}{l}\text { prospecção de veículos para compra; aquisição propriamente dita e seu } \\
\text { acompanhamento; precificação das peças reutilizáveis; atendimento e negociação junto } \\
\text { ao consumidor; contratação de empresas de coleta; e entregas dos produtos. }\end{array}$ \\
\hline $\begin{array}{l}\text { análise técnica prévia das condições do veículo; verificação das condições do veículo no } \\
\text { recebimento; conferência da Lista de Peças Possivelmente Reutilizáveis; elaboração do } \\
\text { Plano de Despoluição e Desmontagem; definição dos procedimentos de análise da } \\
\text { qualidade; classificação das peças; definição da estratégia de gerenciamento a ser } \\
\text { tomada; elaboração dos laudos técnicos. }\end{array}$ \\
\hline $\begin{array}{l}\text { movimentações do veículo no centro de reaproveitamento; despoluição e desmontagem } \\
\text { integral do veículo; realização de testes de verificação; etiquetagem das peças; } \\
\text { preenchimento da Ficha de Análise Técnica do Veículo; aplicação de técnicas de } \\
\text { renovação, reparação e recondicionamento; atualizações do registro do veículo no } \\
\text { sistema de informação; embalagem de peças vendidas. }\end{array}$ \\
\hline
\end{tabular}

A possibilidade de combinação de duas funções por um mesmo colaborador é sugerida, tendo em vista a pequena quantidade de pessoas envolvidas. Sendo assim, orienta-se que o proprietário tenha a função técnica, um colaborador tenha as funções operacional e comercial, outro tenha as funções operacional e administrativa e o terceiro apenas a função operacional.

Tendo em vista a realidade observada no Distrito Federal, na qual os proprietários são os maiores responsáveis pelas atividades do centro, o modelo orienta que ele continue envolvido, mas que passe a ter uma posição de supervisão ou de apoio nas funções administrativo, comercial e operacional. Para isso, a sugestão é que sejam realizados treinamentos práticos com os colaboradores.

Por fim, com intuito de manter o interesse da equipe nas tarefas realizadas e, principalmente, de dar maior robustez ao centro de reaproveitamento em caso de desligamento ou ausência de algum dos colaboradores, propõe-se que seja implementada a prática de revezamento controlado do trabalho periodicamente, com exceção da função técnica. 


\subsection{CARACTERIZAÇÃO DE EQUIPAMENTOS}

Em relação aos bens de produção necessários ao processo de reaproveitamento de veículos em fim de vida útil, é reforçada a dificuldade experimentada pelas unidades do Distrito Federal em possuí-los. O diagnóstico realizado (seção 3.5.3.) mostra que há disponibilidade de ferramentas mecânicas básicas e, em alguns casos, de vaporizadores d'água e elevadores de veículos.

Por isso e em virtude de o modelo proposto se ater apenas ao estágio inicial de adaptação e melhoria dos centros de reaproveitamento, considerações sobre os equipamentos são colocadas, mas elas não abordam as opções mais modernas e tecnológicas existentes. Em caso de possibilidade, orienta-se que o material de Cruz-Rivera (2008) seja consultado, visto que ele apresenta equipamentos de alta eficiência projetados especificamente para esse tipo de operação.

Assume-se que o ferramental simples e alternativo é preferido em relação aos equipamentos sofisticados e de alto valor financeiro. Sendo assim, foram definidos os equipamentos mecânicos essenciais para cada uma das atividades do processo de reaproveitamento proposto. Primeiramente, para a aquisição não há necessidade de qualquer equipamento mecânico visto que o levantamento e a compra de veículos são feitos pessoalmente ou por meio de tecnologia da informação.

Já na atividade de recebimento será necessário movimentar o veículo para a área de estoque. Nesse momento, pode ser que o veículo ainda se movimente, mas pode ocorrer de ele já chegar com a circulação inviabilizada. Quando isso ocorrer, o equipamento adequado é uma empilhadeira (com garfos compatíveis com um veículo). Entretanto, se o centro de reaproveitamento não possuir capacidade financeira de obtê-la, é possível compartilhá-la com outros centros ou construir rusticamente um equipamento substituto.

Para a atividade seguinte, a liberação, não há qualquer equipamento mecânico, diferentemente da despoluição, que exige alguns: uma empilhadeira para movimentação do veículo para a área de despoluição e dela para a do estoque, se necessário; um vaporizador d'água para limpeza do veículo, que ainda pode ser simplificado por mangueira; um elevador de veículos para facilitar a retirada dos fluídos; e ferramentas mecânicas.

Além disso, a desmontagem pode exigir ferramentas mecânicas adicionais capazes de separar as peças externas relacionadas à carroceria do veículo, aos itens de tapeçaria, aos 
vidros, aos componentes mecânicos, elétricos e eletrônicos e aos itens de segurança. A mesma situação pode acontecer com a análise da qualidade, para realização dos testes de verificação e para aplicação das técnicas de renovação, reparação e recondicionamento, em alguns casos.

Nesse sentido, reforça-se que, no caso de o valor dos equipamentos necessários à separação de alguma peça específica ou à aplicação das técnicas comentadas ser acima do viável para o centro de reaproveitamento, uma avaliação de custo e benefício precisa ser realizada considerando a possibilidade de encaminhamento das peças para outras empresas especializadas.

A armazenagem apenas movimenta as peças classificadas e etiquetadas para as áreas de estoque adequadas. Não há necessidade obrigatória de equipamento para essa atividade, mas se o centro de reaproveitamento possuir uma empilhadeira, ela pode ser adaptável para uso com veículos e com peças pesadas. A saída não exige bem de produção para implementação.

A Tabela 4.11 consolida os equipamentos mecânicos essenciais para cada uma das atividades propostas pelo modelo para o processo de reaproveitamento de veículos em fim de vida útil.

Tabela 4.11 Definição dos equipamentos mecânicos essenciais por atividade proposta

\begin{tabular}{l|c|c|c|c}
\hline $\begin{array}{c}\text { Atividade/ } \\
\text { Equipamento }\end{array}$ & $\begin{array}{c}\text { Empilhadeira para } \\
\text { veículos e peças }\end{array}$ & $\begin{array}{c}\text { Vaporizador } \\
\text { d'água }\end{array}$ & $\begin{array}{c}\text { Elevador de } \\
\text { veículos }\end{array}$ & $\begin{array}{c}\text { Ferramentas } \\
\text { mecânicas }\end{array}$ \\
\hline Aquisição & & & & \\
\hline Recebimento & $\mathrm{x}$ & & & \\
\hline Liberação & $\mathrm{x}$ & $\mathrm{x}$ & $\mathrm{x}$ & $\mathrm{x}$ \\
\hline Despoluição & $\mathrm{x}$ & $\mathrm{x}$ & $\mathrm{x}$ \\
\hline Desmontagem & $\mathrm{x}$ & & & $\mathrm{x}$ \\
\hline Análise Qualidade & $\mathrm{x}$ & & & \\
\hline Armazenamento & & & & \\
\hline Saída & & & & \\
\hline
\end{tabular}

Ademais dos equipamentos mecânicos necessários ao processo de reaproveitamento, é importante comentar sobre os equipamentos de tecnologia da informação também fundamentais para o modelo proposto. Eles são os responsáveis pela comunicação entre os diferentes atores da cadeia de reaproveitamento, pelos registros fiscais de entrada e saída, pelo controle dos veículos e das peças em processamento, pela divulgação de peças no $e$ commerce, pela gestão do centro como empresa, pela coleta e armazenamento de dados. 
Nesse sentido, propõe-se que cada centro de reaproveitamento possua pelo menos um smartphone e um computador. O smartphone além de permitir o contato sonoro entre a equipe do centro e os seus fornecedores/ consumidores, também deve ser utilizado para fotografias das peças para o mercado virtual. Na Renova Ecopeças essa tarefa é realizada em um estúdio com equipamentos profissionais, mas essa não é a realidade das unidades do Distrito Federal.

No computador, que deve ter acesso à internet, deve-se fazer a instalação do sistema para emissão de nota fiscal eletrônica, do sistema de informação que será disponibilizado pelo DETRAN-DF e de um sistema próprio de controle operacional para rastreabilidade das etapas do processo de desmontagem, de forma a garantir toda a segurança ao consumidor final e permitir a fiscalização pelos órgãos públicos competentes, para atendimento da Resolução CONTRAN 611/ 2016.

\subsection{CARACTERIZAÇÃO DA INFRAESTRUTURA NECESSÁRIA}

\subsubsection{Localidade da Infraestrutura}

A Classificação Nacional de Atividades Econômicas (CNAE) utilizada pelos centros de reaproveitamento registrados pelo DETRAN-SP é a de número 4530-7/04: comércio a varejo de peças e acessórios usados para veículos automotores. O modelo proposto considera que as empresas do Distrito Federal, quando registradas, também terão essa CNAE.

A partir dela e das definições contidas no Projeto de Lei Complementar 79/ 2013 - Lei Complementar de Uso e Ocupação do Solo (LUOS) do DF -, que está em estágio de revisão na câmara legislativa, é possível identificar as onze opções de Unidades de Uso e Ocupação de Solo (UOS) nas quais o tipo de atividade dessa CNAE pode ser exercida. O Anexo A descreve cada uma delas.

Dessas onze possibilidades, devem ser priorizadas as CSII 1, 2 e 3, bem como as CSIInd 1 e 2, em virtude de permitirem comércio, prestação de serviço, institucional e industrial, sendo as três primeiras com proibição de residência e as duas últimas com previsão de áreas de oficinas e separação das áreas habitacionais.

Apesar de aparentar uma restrição, observa-se que existem unidades CSII 1, 2, 3 e/ou CSIInd 1 e 2, em todas as regiões administrativas abrangidas pela LUOS, com exceção do 
Parkway e do Varjão. Sendo assim, o centro de reaproveitamento poderia se localizar em espaços específicos de: Águas Claras, Brazlândia, Ceilândia, Gama, Guará, Lago Norte, Lago Sul, Núcleo Bandeirante, Paranoá, Planaltina, Recanto das Emas, Riacho Fundo, Riacho Fundo II, Samambaia, Santa Maria, São Sebastião, SCIA, SIA, Sobradinho, Sobradinho II e Taguatinga.

\subsubsection{Delimitação de Áreas da Infraestrutura}

O tamanho do centro de reaproveitamento não é especificado, desde que ele atenda às exigências impostas. De acordo com a Lei 12.977/ 2014, para que o centro de reaproveitamento seja registrado ele precisa possuir infraestrutura de desmontagem de veículos isolada fisicamente de qualquer outra atividade. A Resolução CONTRAN 611/ 2016 obriga apenas uma área de recuperação de peças.

Na mesma direção, Cruz-Rivera (2008) diz que independentemente do tamanho ou do arranjo físico proposto para o centro de reaproveitamento, o essencial é que ele atenda às áreas de operação definidas para realização das atividades. Sendo assim, o modelo propõe algumas áreas, próximas às de Cruz-Rivera (2008) e bastante alinhadas às tarefas desempenhadas e aos estoques formados ao longo do processo de reaproveitamento.

- Administrativo e Atendimento: área para desenvolvimento das funções administrativas e comerciais, principalmente aquisição, registro, emissão de nota fiscal, atendimento ao consumidor, e-commerce, atualização do sistema de informação. Nela deve haver uma ou duas estações de trabalho com computadores e materiais de escritório. É importante que haja espaço para arquivo de documentos dos veículos e do centro de reaproveitamento.

- Estoque de veículos: área para a qual o veículo recebido é encaminhado para análise e registro até que seja liberado. A Resolução CONTRAN 611/ 2016 e também CruzRivera (2008) reforçam que essa área precisa possuir piso impermeável e canaletas de contenção de fluidos. Essa área também pode ser utilizada por veículos já despoluídos em caso de haver fila para a desmontagem.

- Despoluição: área na qual são realizadas as tarefas de despoluição. A Resolução CONTRAN 611/ 2016 e também Cruz-Rivera (2008) reforçam que essa área precisa possuir piso impermeável e canaletas de contenção de fluidos. Além disso, a mesma 
resolução exige que haja caixa separadora de água e óleo, bem como recipientes adequados ao armazenamento dos fluidos coletados.

- Desmontagem: área para realização das tarefas de desmontagem do veículo. A Resolução CONTRAN 611/ 2016 exige que essa área possua piso impermeável, orientação que é reforçada por Neufert (2013) no exemplo de oficinas mecânicas.

- Análise da qualidade: área na qual são realizados os testes de verificação da qualidade das peças desmontadas do veículo, bem como a classificação, a definição da estratégia de gerenciamento a ser adotada, a precificação e a etiquetagem de cada uma delas. Em caso de necessidade, nessa área também são aplicadas as técnicas de renovação, reparação e recondicionamento.

- Estoque de peças: se houver possibilidade, o modelo sugere que essa área seja subdividida em área das peças reutilizáveis e das não reutilizáveis. Nela são armazenadas as peças disponíveis para venda e as que aguardam a data de retirada das empresas recicladoras e transportadoras, confome os grupos descritos na seção 4.3.7. A Resolução CONTRAN 611/ 2016 exige que essa área também tenha piso impermeável.

Ainda sobre áreas da infraestrutura do centro de reaproveitamento, uma boa prática observada no estado de São Paulo foi a delimitação de um espaço para tratamento de água da chuva para uso na despoluição dos veículos, entretanto, tendo em vista o estágio inicial das empresas do Distrito Federal, essa ação ficará para modelos posteriores.

Complementarmente, coloca-se que normalmente a infraestrutura é de pavimento único e em estrutura metálica, mas que não há obrigatoriedade nesse sentido. Também como orientação, Neufert (2013) sugere que sejam privilegiados galpões sem pilares intermediários para facilicar a alocação das áreas dentro do espaço físico.

\subsubsection{Proposição Preliminar de Arranjo Físico}

De acordo com Slack, Chambers e Johnston (2009), o arranjo físico é a manifestação física do processo e por isso está relacionado a ele. Anteriormente o modelo propôs o processo de jobbing (seção 4.2), para o qual dois tipos básicos de arranjo são recomendados pelos autores: posicional ou funcional.

Para o contexto do estágio inicial do Distrito Federal, propõe-se o tipo de arranjo físico funcional porque ele permite que as atividades do centro de reaproveitamento como, por exemplo, despoluição e desmontagem, sejam realizadas em paralelo com diferentes 
veículos, dado que é organizado conforme as funções desempenhadas pelos recursos transformadores que constituem os processos e que, no estudo, são compartilhados.

Mesmo com a proposta do arranjo físico funcional, tendo em vista que o tamanho para o centro de reaproveitamento não é especificado na regulamentação, o modelo faz apenas uma proposição preliminar de arranjo físico, mostrada na Figura 4.4, para o estágio inicial, com tamanhos considerados satisfatórios para as diferentes áreas propostas na seção 4.6.2.

A área total em torno de $200 \mathrm{~m}^{2}$ (finalizada em $240 \mathrm{~m}^{2}$ ) foi uma restrição para que ela se mantivesse próximo à dos menores centros de reaproveitamento observados no Distrito Federal. O espaço de circulação e o tamanho do estoque de veículos, que considera a alocação de quatro vagas de estacionamento, foram colocados de acordo com os tamanhos mínimos estipulados pela Lei 2.108/ 1998 - Código de Edificações do Distrito Federal. Por outro lado, os estoques de peças e de despoluição foram ajustados em relação aos propostos por Cruz-Rivera (2008).

Os tamanhos das áreas de despoluição e desmontagem foram baseados nos estudos realizados por Neufert (2013) para oficinas mecânicas, tendo em vista que os recursos de transformação (pessoas e equipamentos mecânicos) são semelhantes. A mesma consideração foi utilizada para a área de análise da qualidade, mas que sofreu pequena redução, tendo em vista que não trabalha com veículos (grande tamanho), mas com peças (tamanho menor).

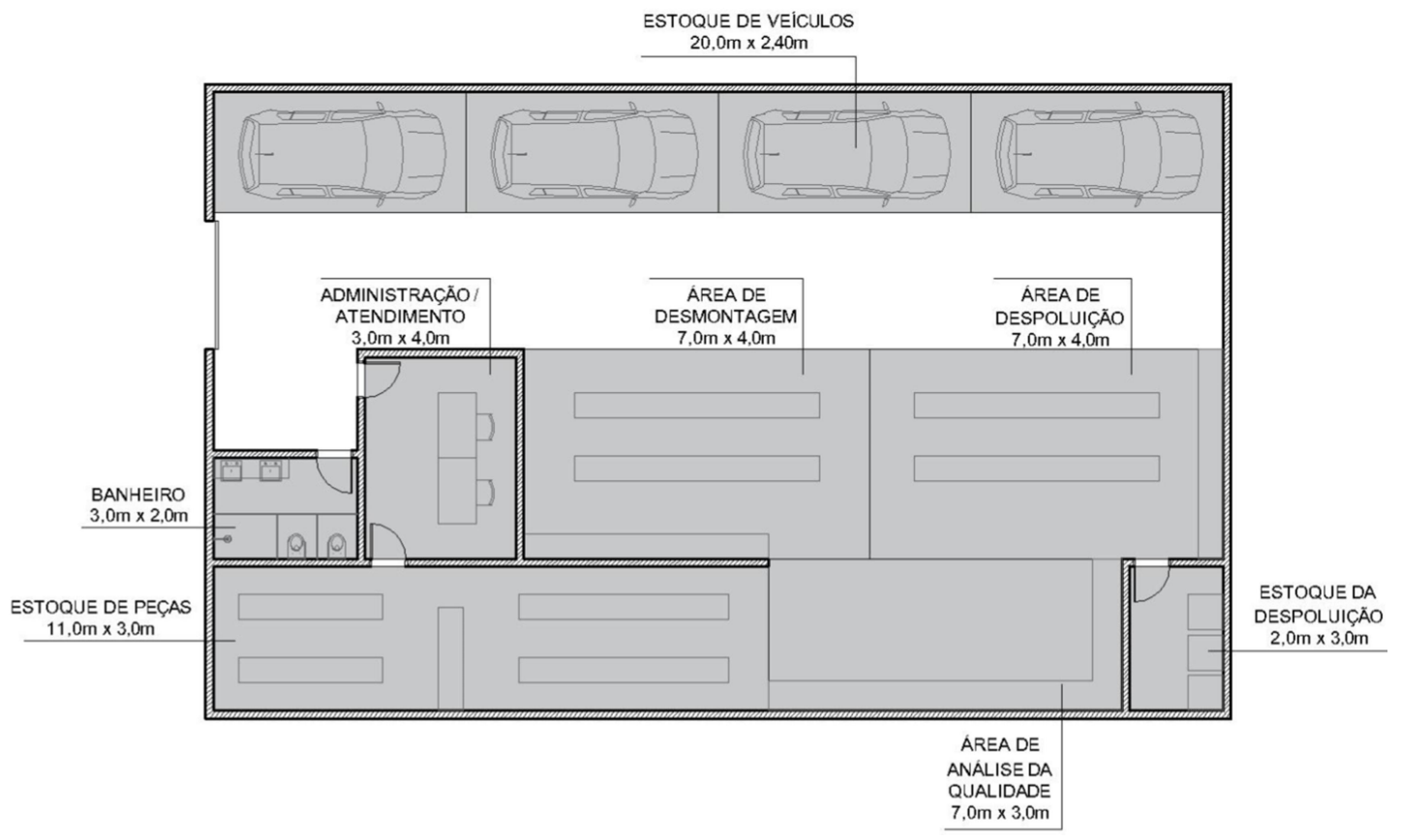

Figura 4.4 Arranjo físico preliminar proposto pelo modelo de centro de reaproveitamento 
Ressalta-se, entretanto, que a disposição das áreas dentro do arranjo físico pode precisar ser alterada de acordo com o formato e com as condições da instalação. Nesse momento, o modelo orienta que o empresário atende-se à ventilação e à claridade, para que o centro de reaproveitamento seja um ambiente confortável para os colaboradores.

Uma prática analisada na Renova Ecopeças e que é julgada como interessante inclusive para o estágio inicial é a marcação colorida no piso dos espaços destinados a cada uma das áreas. Ela é bastante observada em empresas que aplicam ferramentas de produção enxuta e acredita-se que promova a organização e a estruturação da unidade produtiva, objetivo que se pretende alcançar no Distrito Federal.

\subsection{MODELAGEM DO DIAGRAMA DO LAÇO CAUSAL}

Como já discutido na introdução do capítulo 4, o modelo proposto nesta dissertação representa apenas o estágio inicial dos centros de reaproveitamento do Distrito Federal, considerando um amplo processo de desenvolvimento, implementação e aprimoramento gradual que exigirá melhorias em estágios posteriores. De toda forma, acredita-se que já é possível fazer uma contribuição para os próximos estágios.

Sendo assim, o diagrama do laço causal foi escolhido para orientar os atores envolvidos a compreenderem as variáveis chaves, bem como o relacionamento (positivo ou negativo) entre elas, e a estrutura do problema. A partir deste conhecimento, a identificação dos dados que precisam ser coletados na implementação do modelo no estágio inicial para futuras tomadas de decisão se torna mais palpável. Com esse intuito, não há necessidade de diferenciar as variáveis de estoque e de fluxo.

Nesse sentido, percebe-se que o modelo proposto espera que o diagrama de laço causal seja uma ferramenta capaz de estimular a continuidade da pesquisa em trabalhos futuros, com a aplicação efetiva das orientações, a coleta dos dados sugeridos, a realização de simulações, a determinação para melhoria e o aprimoramento dos resultados do centro de reaproveitamento no Distrito Federal.

\subsubsection{Considerações Gerais sobre o Diagrama do Laço Causal}

Como colocado por Sterman (2000), a modelagem não está isolada, mas inserida em um contexto social. No problema em questão, o ambiente apresentado pelo diagnóstico realizado com as empresas atuantes no Distrito Federal contribui com as características da 
realidade existente: indisponibilidade de dados, escassez de pessoas capacitadas e equipamentos adequados, informalidade de processos.

Entretanto, a dissertação propõe um novo modelo de centro de reaproveitamento a ser adotado na localidade, que altera o processo e a composição das pessoas, dos equipamentos e tecnologias, da infraestrutura e do arranjo físico. Sendo assim, o diagrama do laço causal aborda o cenário recomendado e, por isso, as fronteiras são estabelecidas com relação à transformação de veículos em fim de vida útil para peças reutilizáveis ou não reutilizáveis, realizada pelo centro de reaproveitamento proposto.

Nessa operação, em linhas gerais, o centro de reaproveitamento precisa balancear a entrada de veículos adquiridos com as informações obtidas de demanda e de estoque existentes. Paralelamente, deve equilibrar os variados status nos quais os veículos em transformação podem estar com os recursos disponíveis dentro da planta e com os contratados de terceiros (transporte e/ou tratamento).

Foi necessário simplificar alguns elementos para manter o modelo compreensível. Nesse sentido, os diferentes tipos de tratamento que podem ocorrer nas peças passíveis de reutilização (renovação, reparação e recuperação) foram abordados conjuntamente como tratamento, assim como as estratégias de gerenciamento de peças não reutilizáveis (reciclagem, remanufatura, destinação final). Também, os recursos específicos de cada status de transformação englobaram recursos capitais e de infraestrutura (área adequada).

Já os recursos humanos foram incluídos no diagrama como variável central que se relaciona com muitas outras variáveis dos status de transformação do veículo em fim de vida, visto que, dentro do modelo proposto, a quantidade de pessoas é reduzida e que os mesmos colaboradores dividem-se nas diferentes tarefas.

\subsubsection{Descrição do Diagrama do Laço Causal}

A Figura 4.13 apresenta o diagrama do laço causal desenvolvido. A partir dela, percebe-se que a quantidade de veículos em fim de vida útil prematuramente e a quantidade de veículos com idade avançada são variáveis exógenas. Elas se relacionam em sentido inverso, pois quando há aumento na primeira, a segunda será consequentemente reduzida. De toda forma, ambas adicionam aos veículos em análise para aquisição por aumentarem a oferta disponível para o centro de reaproveitamento. 
Os veículos em análise para aquisição acarretam em veículos adquiridos a depender da taxa de veículos em boas condições técnicas e da de veículos com documentação regularizada, variáveis externas, ademais do histórico de peças vendidas e de informações do giro do estoque, das peças reutilizáveis em armazenamento e das não reutilizáveis encaminhadas para estratégias de gerenciamento. Sendo assim, os veículos adquiridos são impactados pela própria matéria-prima, pela demanda existente e pela capacidade de atendimento do centro.

Os veículos adquiridos provocam veículos em recebimento quando eles são obtidos no próprio centro de reaproveitamento ou, em algumas circunstâncias, necessidade de transporte, impactada pela taxa de veículos adquiridos fora do Distrito Federal. Sendo assim, pode haver um gap de veículos para transporte tendo em vista a necessidade de transporte, a capacidade do veículo de transporte e a quantidade de veículos adquiridos por outros centros do Distrito Federal. O gap incentiva o ajuste do veículo para uma capacidade menor ou maior, a depender do caso, e então a alteração no veículo pode reduzir o gap existente, finalizando o loop B1, representado pela Figura 4.5.

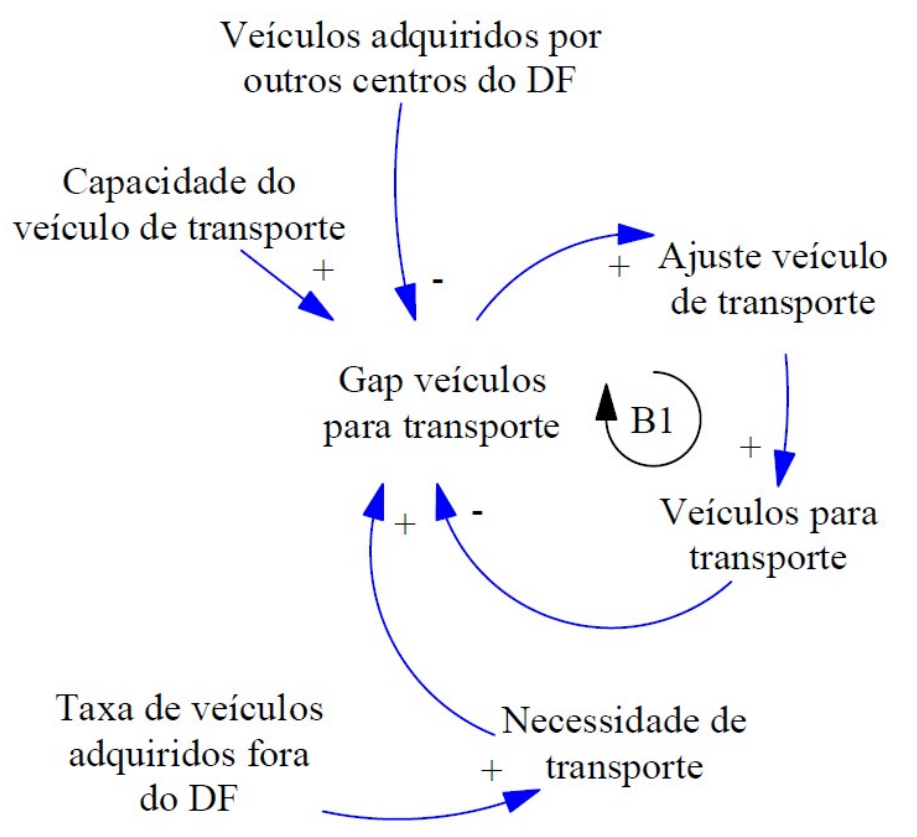

Figura 4.5 Loop B1 de balanceamento dos veículos para transporte

Quando ajustados os veículos, inicia-se o transporte, que é impactado negativamente pelo tempo do trajeto a ser realizado, que por sua vez é influenciado positivamente pela distância do trajeto e negativamente pela velocidade média desempenhada. A variável de veículos em recebimento também é relacionada com a capacidade do estoque de veículos, 
obrigando que haja espaço para que os veículos entrem efetivamente no centro de reaproveitamento. Ela encerra o loop B2, ilustrado na Figura 4.6.

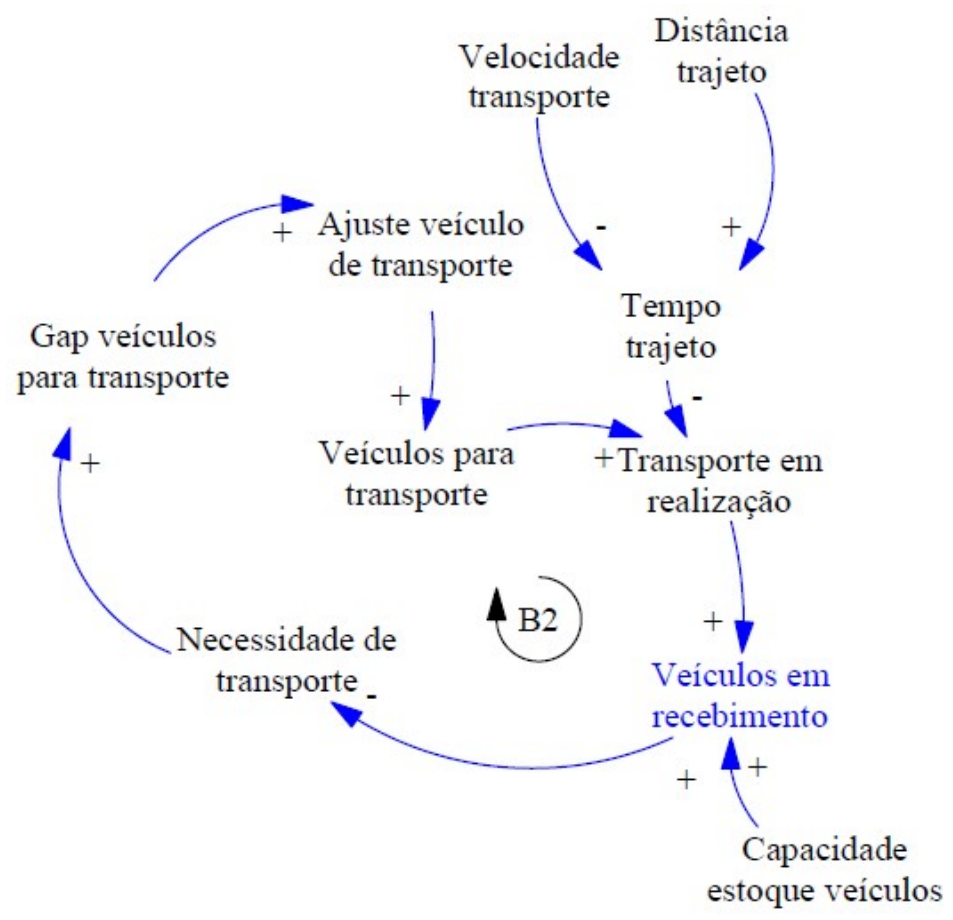

Figura 4.6 Loop B2 de balanceamento dos veículos em recebimento

Em seguida, os veículos passam para o status recebido a depender do tempo de verificação para recebimento, que precisa ser menor que a janela de tempo estabelecida pela Lei 12.977/ 2014 e pela Resolução CONTRAN 611/ 2016 para o recebimento, bem como da taxa de aprovação da verificação do veículo em relação ao contratado na aquisição, ou seja, do percentual de veículos que no recebimento atentem às expectativas da aquisição.

O veículo em liberação encontra-se alocado especificamente para elaboração do seu Plano de Despoluição e Desmontagem, enquanto aguarda a obtenção do Certificado de Baixa de Veículo, quando modifica para veículo liberado, decorrido o tempo de emissão do DETRAN-DF.

Autorizada a continuidade das atividades, os veículos em despoluição dependem dos recursos adequados às suas tarefas. Sendo assim, o loop B3, mostrado na Figura 4.7, ressalta a necessidade de recursos para despoluição, dependente da capacidade do estoque de veículos, da janela de tempo para despoluição e da produtividade dos equipamentos. A necessidade de recursos também mostra o possível gap existente entre recursos e o que é preciso, o ajuste realizado e a disponibilidade dos recursos que contribuem para os veículos despoluídos. 


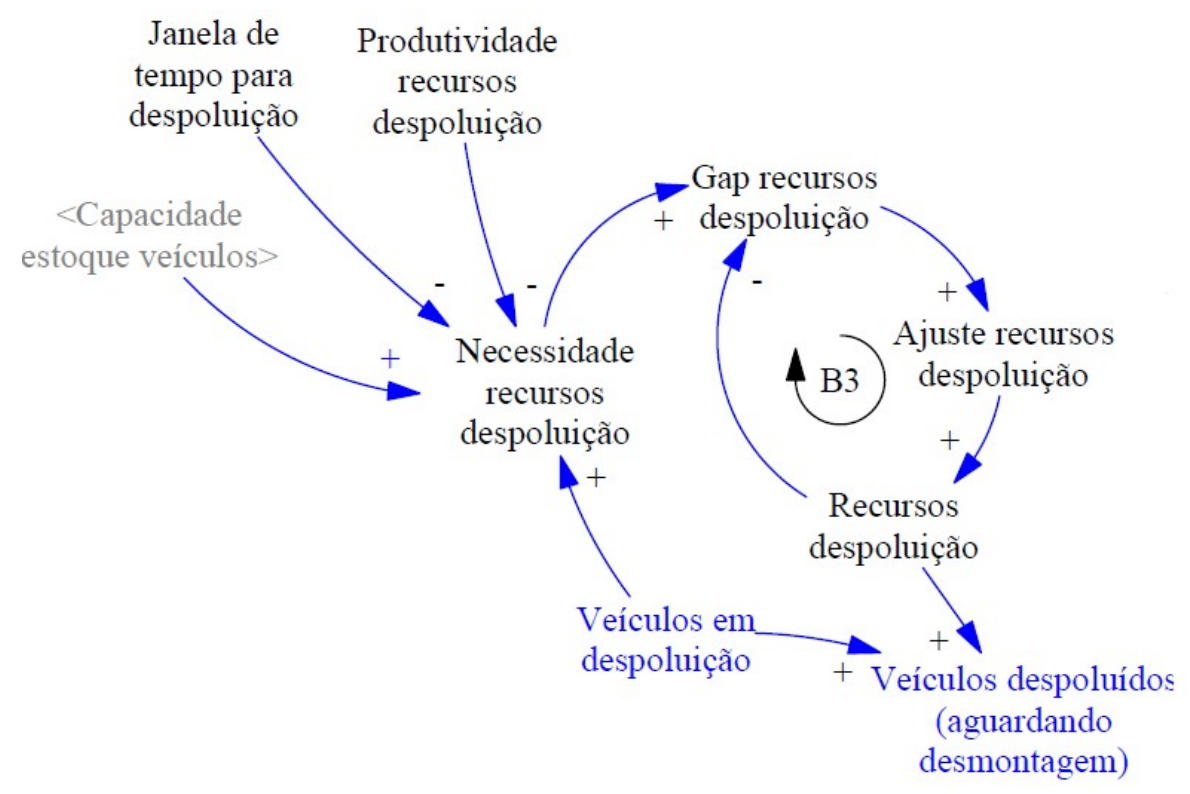

Figura 4.7 Loop B3 de balanceamento dos recursos para despoluição

Loops similares são relacionados às seguintes variáveis: veículos em desmontagem, peças em análise técnica, peças em tratamento e peças não reutilizáveis em armazenamento. Eles sinalizam o alinhamento que deve existir entre os recursos disponíveis no centro e a quantidade de veículos em transformação que percorrem os variados status.

Assim, sucintamente, os veículos despoluídos direcionam para os veículos em desmontagem, com loop B4 (Figura 4.8); que encaminha para peças desmontadas; e, em seguida, para peças em análise técnica, com loop B5 (Figura 4.9); que, por fim, contribui para a variável de peças analisadas e classificadas.

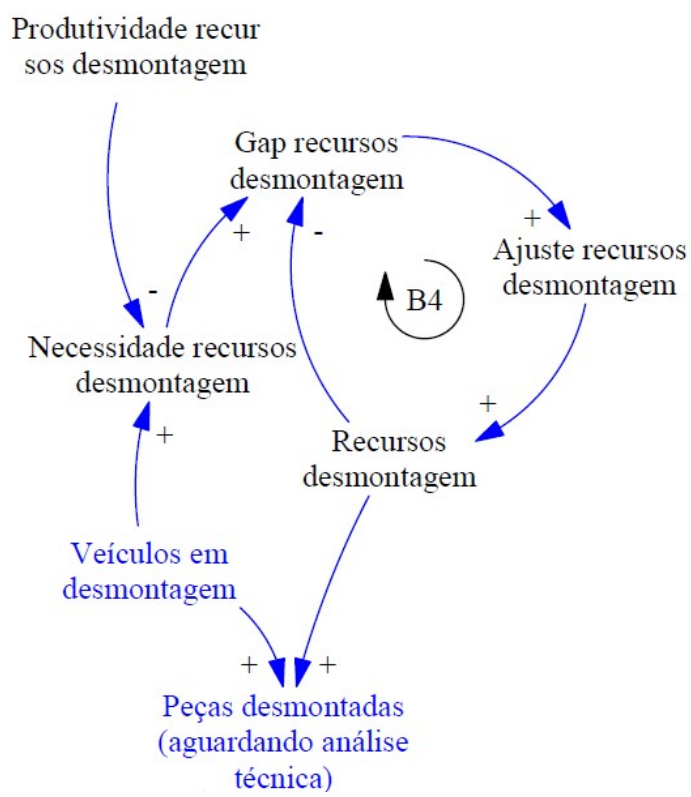

Figura 4.8 Loop B4 de balanceamento dos recursos para desmontagem 


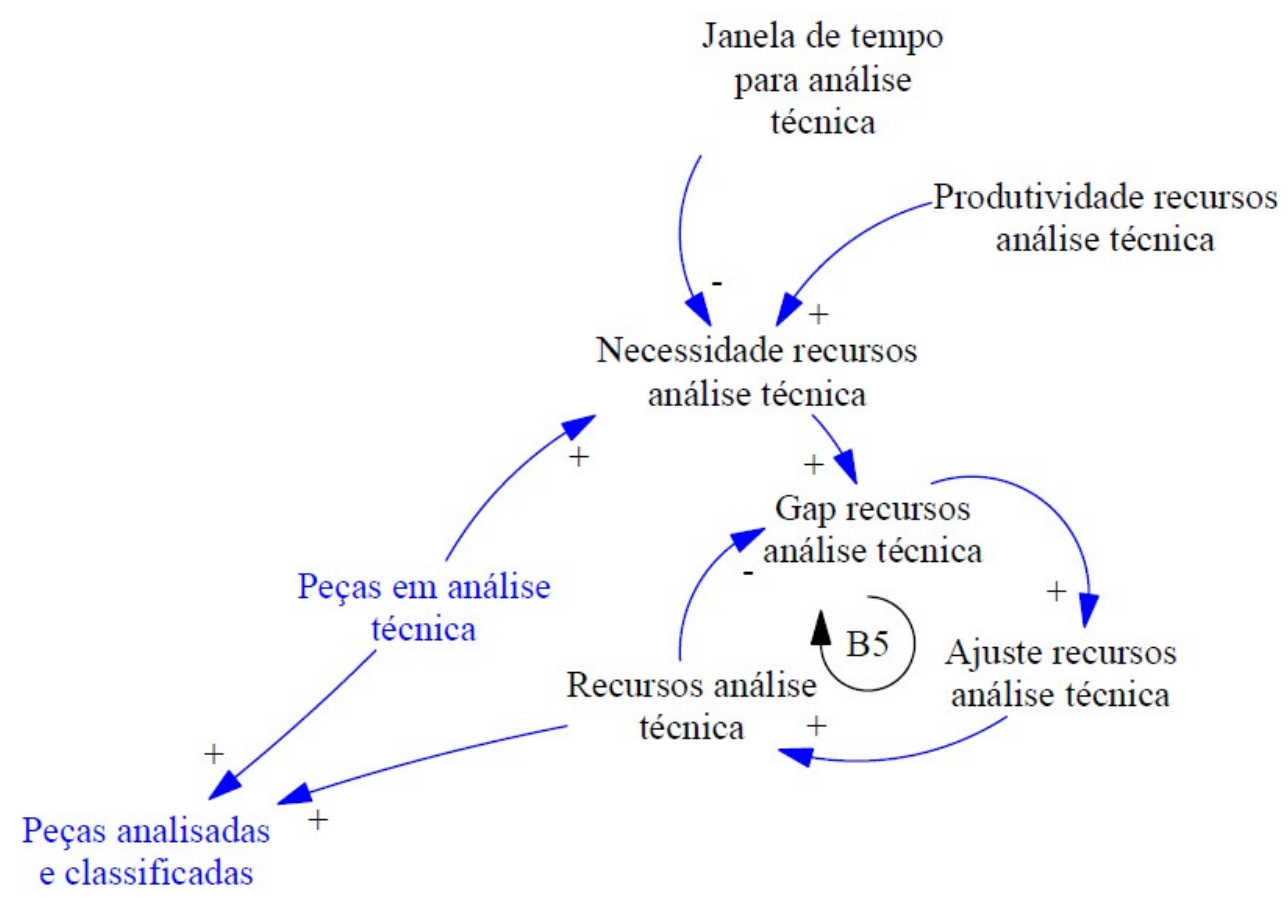

Figura 4.9 Loop B5 de balanceamento dos recursos para análise técnica

As peças analisadas e classificadas se relacionam positivamente com as peças reutilizáveis, não reutilizáveis e passíveis de reutilização, que possuem complementariedade em entre si demonstrada pelas taxas de aprovação, reprovação e passíveis de reutilização. Assim, a subtração de uma primeira taxa por uma segunda resulta na terceira. Também, o aumento de qualquer uma delas provoca a redução das demais.

Especificamente as peças passíveis de reutilização aumentam as peças em tratamento, que possui relacionamento com loop $\mathrm{B} 6$, semelhante aos anteriores, com tendência de balanceamento e contribuição para peças analisadas e classificadas. Isso ocorre porque após a realização do tratamento da peça passível de reutilização, ela é submetida a uma análise da qualidade que a classifica como reutilizável ou não. Sendo assim, entende-se que a peça classificada como passível de reutilização ainda está em estágio intermediário para definição da sua estratégia de gerenciamento final. 


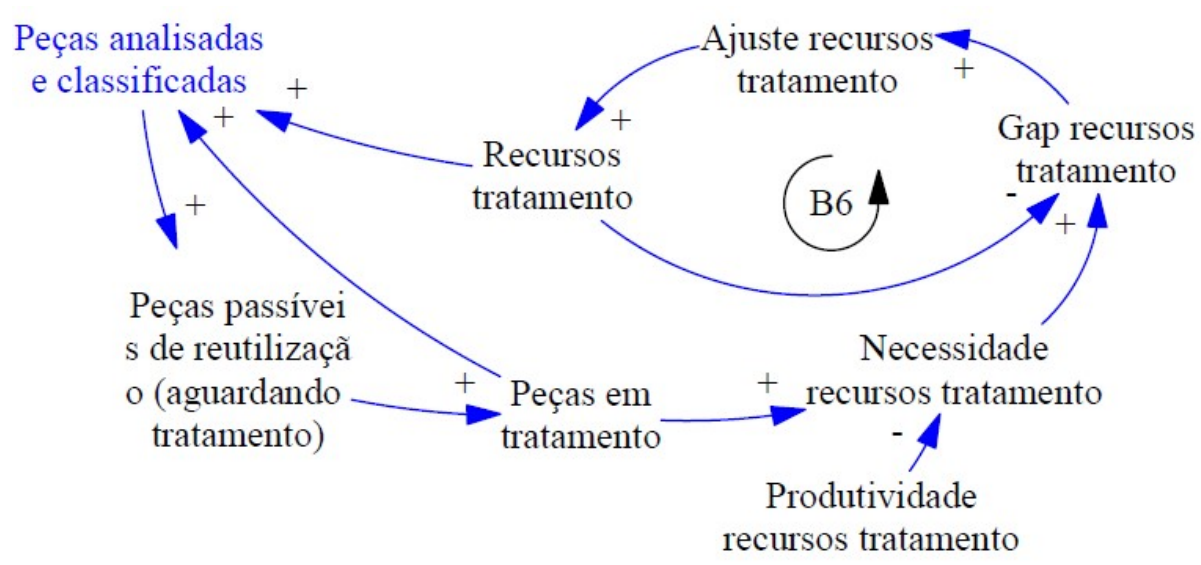

Figura 4.10 Loop B6 de balanceamento dos recursos para tratamento

As peças não reutilizáveis são, então, influenciadas positivamente pela taxa de reprovação da desmontagem e também negativamente pela taxa de aprovação do tratamento realizado na peça passível de reutilização. Elas impactam diretamente nas peças não reutilizáveis em armazenamento, que se encontram estocadas no centro de reaproveitamento aguardando a sua retirada para implementação de estratégia de gerenciamento.

Esse tipo de peças em armazenamento depende da capacidade existente, sendo que quanto maior o volume disponível, maior quantidade de peças podem ser estocadas e, também, pode ocasionar o loop B7 de necessidade de veículo para encaminhamento, similar aos anteriores, com influência de uma janela de tempo para realização do encaminhamento, estabelecida pela legislação (20 dias úteis). Ele é apresentado na Figura 4.11.

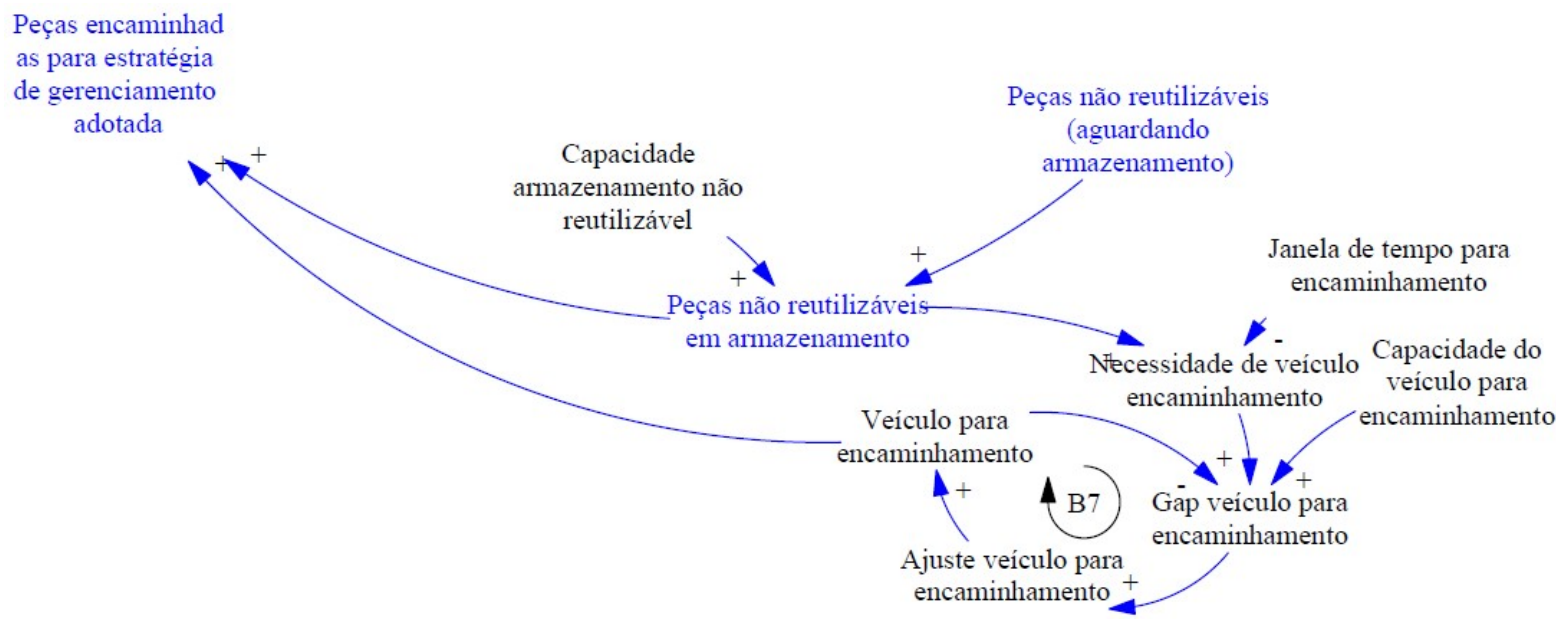

Figura 4.11 Loop B7 de balanceamento do veículo para encaminhamento de peças não reutilizáveis para estratégia de gerenciamento

Quando disponibilizado o veículo para encaminhamento, as peças são encaminhadas para a estratégia de gerenciamento selecionada. As informações referentes à quantidade de peças 
destinadas, bem como às estratégias mais adequadas são insumo para a tomada de decisão na aquisição de novos veículos para o centro de reaproveitamento.

Retornando às peças reutilizáveis, percebe-se que elas também são relacionadas positivamente com as taxas de aprovação da desmontagem e do tratamento das peças passíveis de reutilização. Por outro lado, elas impactam a variável de peças reutilizáveis em armazemanento que, por sua vez, depende da capacidade disponível para estocagem. Esse tipo de peça em armazenamento influencia positivamente o estoque médio de peças, que impacta negativamente o giro do estoque, variáveis importantes para a análise de veículos para aquisição.

A variável de peças reutilizáveis também incentivam as peças vendidas, sob influência da demanda de peças reutilizáveis do centro de reaproveitamento e do nível de serviço atingido. O histórico de vendas contribui na aquisição de veículos, complementarmente, bem como o próprio registro das peças estocadas no centro de reaproveitamento.

Ainda sobre as peças reutilizáveis em armazenamento, observa-se que elas possuem relacionamento positivo com a variável de necessidade de recursos humanos, que é central no diagrama porque se relaciona com diferentes variáveis: veículos em recebimento, em liberação, em despoluição, em desmontagem, em análise técnica da qualidade, em tratamento, peças não reutilizáveis em armazenamento. Isso porque as atividades do centro de reaproveitamento dependem de pessoas e elas são as mesmas para todas elas.

A necessidade de recursos humanos, assim como as demais necessidades de recursos, relaciona-se com um loop - o B8 - que ilustra o possível gap existente entre demanda e disponibilidade de recursos humanos dentro do centro de reaproveitamento, o ajuste que pode ser feito para reduzir a diferença e a nova disponibilidade de pessoas. O loop B8 é representado na Figura 4.12.

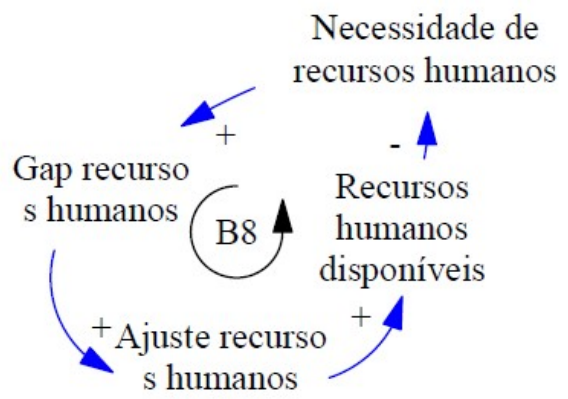

Figura 4.12 Loop B8 de balanceamento dos recursos humanos 
Também na parte interna do centro do diagrama, ilustrado na Figura 4.13, é possível visualizar os loops R1 e B9, que ressaltam, respectivamente, o reforço e o balanceamento existente entre as variáveis que representam as principais atividades do centro de reaproveitamento e a entrada de novos veículos em fim de vida útil.

$\mathrm{Na}$ primeira situação (R1), o crescimento de peças vendidas e do giro de estoque impulsiona o aumento de veículos adquiridos e o centro de reaproveitamento se tornará cada vez maior em capacidade, se sofrer as alterações necessárias adequadamente. $\mathrm{Na}$ segunda (B9), o aumento da quantidade de peças reutilizáveis em estoque e/ ou de peças encaminhadas para estratégias de gerenciamento por não poderem ser reutilizadas inibe a compra de novos veículos em fim de vida útil.

Por fim, na Figura 4.13 o diagrama do laço causal ilustra o problema do modelo de centro de reaproveitamento proposto com as variáveis em destaque sendo as que compõem diretamente os loops R1 e B9, os principais da representação tendo em vista que traduzem a transformação de veículos em fim de vida útil em peças reutilizáveis ou não reutilizáveis. 


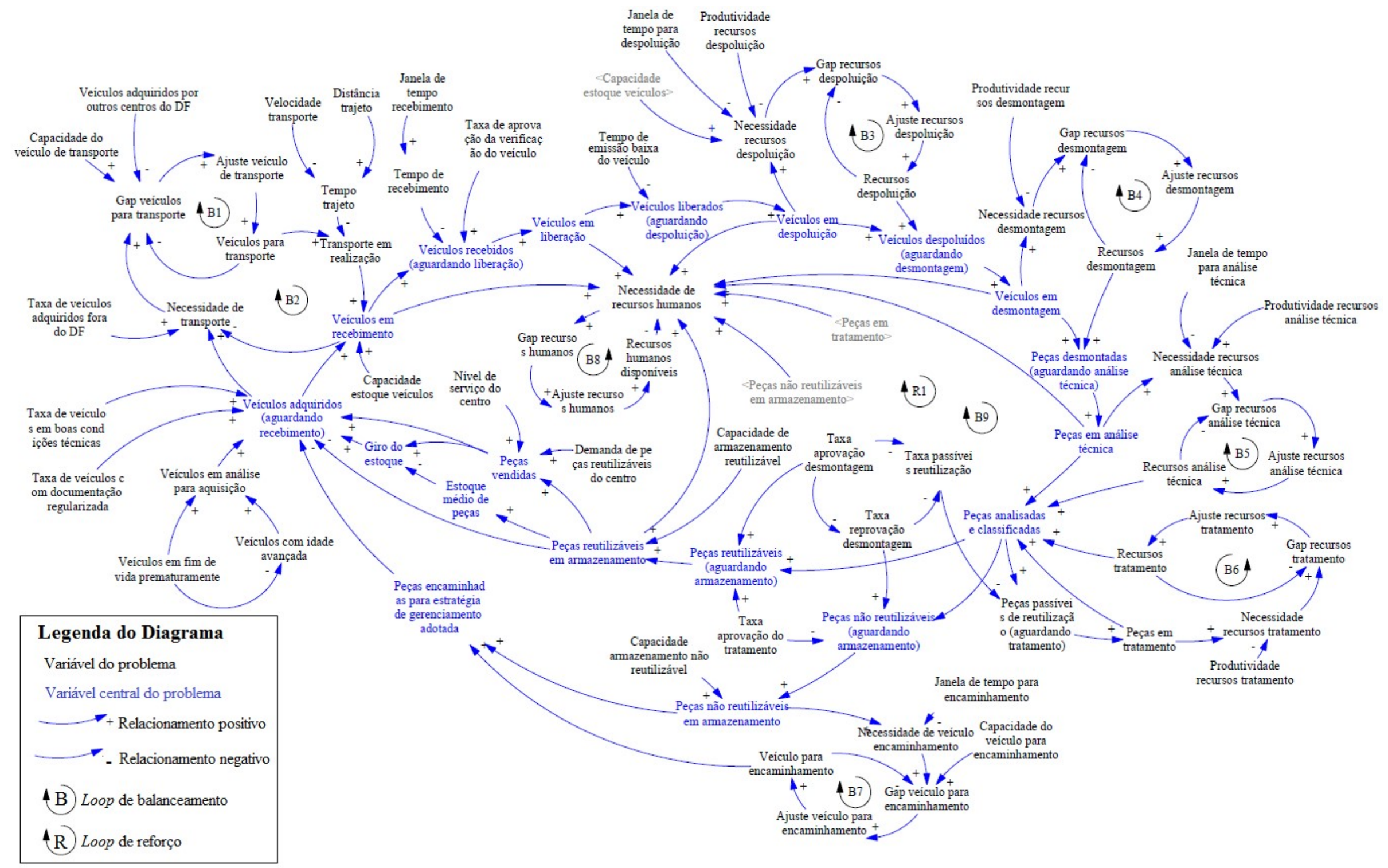

Figura 4.13 Diagrama do laço causal para problema do modelo de centro de reaproveitamento proposto 


\subsection{PROPOSTA PARA CONTROLE DAS INFORMAÇÕES}

O modelo proposto orienta que os centros de reaproveitamento coletem dados já no estágio inicial considerado, para que os posteriores que venham a ser desenvolvidos em trabalhos futuros possam partir de decisões amparadas quantitativamente. O diagrama do laço causal identificou as variáveis relevantes para a estrutura do problema e, portanto, acabou por explicitar os dados que devem ser obtidos.

Sugere-se que esse levantamento de dados seja realizado em conjunto com o preenchimento dos documentos do próprio processo de transformação dos veículos em fim de vida útil. Sendo assim, a Figura 4.14 reforça quais são esses documentos e em que atividades eles são elaborados ou obtidos dentro do processo.

\begin{tabular}{|c|c|}
\hline \multicolumn{1}{|c|}{ 1. Aquisição } \\
\hline \hline 1.1 & $\begin{array}{c}\text { Registro de Leilõese } \\
\text { Venda de Veículos }\end{array}$ \\
\hline \hline 1.2 & $\begin{array}{c}\text { Registro de Análise } \\
\text { de Veículos }\end{array}$ \\
\hline 1.3 & $\begin{array}{c}\text { Lista de Peças } \\
\text { Possivelmente } \\
\text { Reutilizáveis }\end{array}$ \\
\hline 1.4 & $\begin{array}{c}\text { Contrato de } \\
\text { Aquisição de } \\
\text { Veículo }\end{array}$ \\
\hline
\end{tabular}
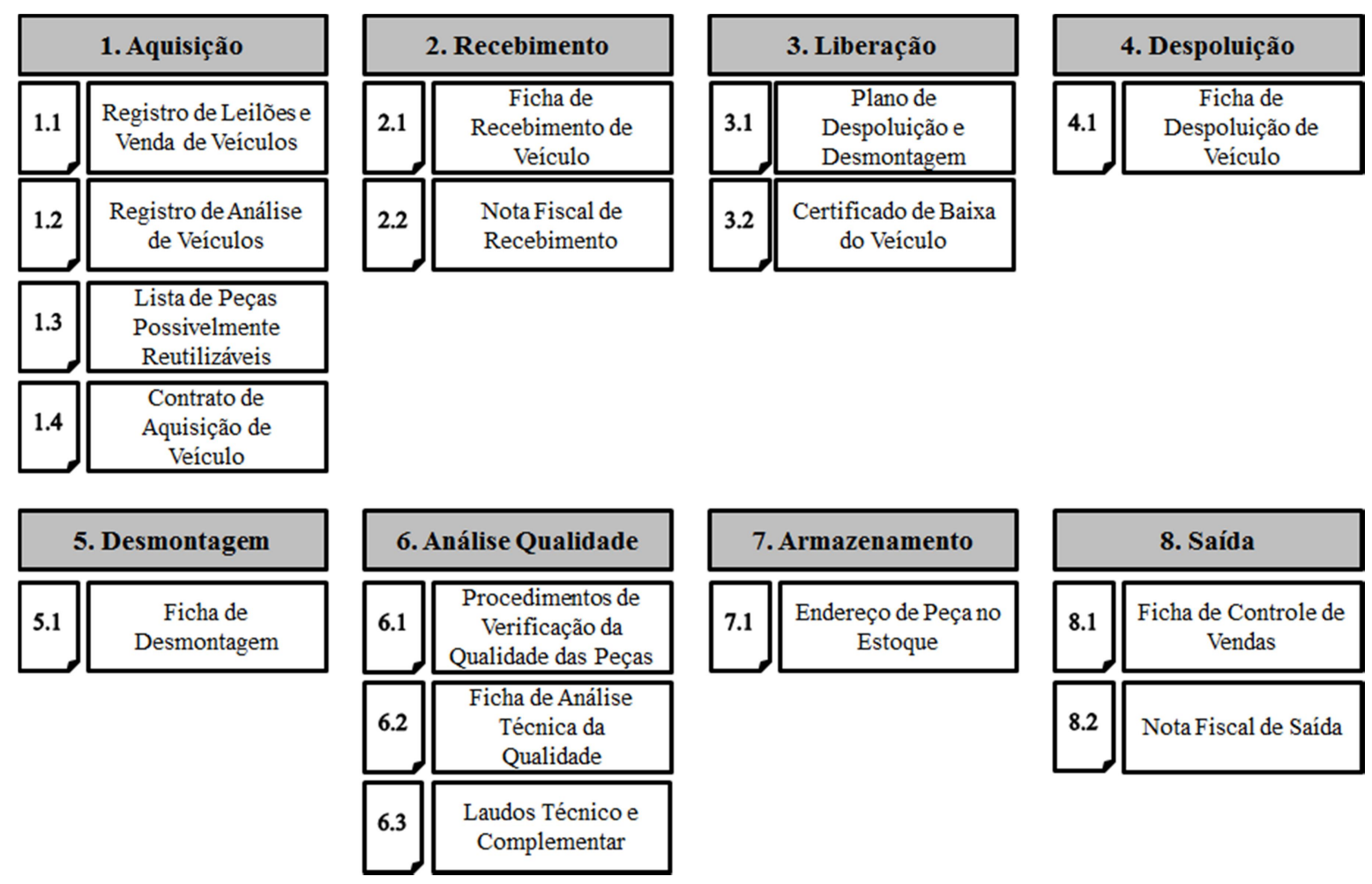

Figura 4.14 Documentos do processo de reaproveitamento de veículos leves proposto

Esses documentos são apenas registros físicos do que será inserido nos sistemas de controle operacional e de fiscalização do DETRAN-DF. Optou-se por essa orientação visto que não há disponibilidade de um computador por área de operação, tampouco por colaborador, e que as condições da internet podem não ser as mais desejáveis.

Yi e Park (2015) solicitam que haja um tablet nas áreas de transformação para coleta de dados, mas o modelo não considera ser fundamental para o estágio inicial. Sendo assim, para evitar que os dados sejam perdidos por qualquer motivo, propõe-se que os 
documentos sejam em versão física, para preenchimento manual no local da operação, e que, em seguida, tenham seus dados digitalizados no computador da área administrativa do centro de reaproveitamento.

Cada um dos documentos é responsável pelo registro de diferentes dados, que normalmente são específicos para um veículo, que está em transformação no momento do preenchimento. Após a repetição da coleta desses dados para um grupo de veículos, eles podem ser consolidados e, então, é possível obter informações que são importantes para o gerenciamento do centro de reaproveitamento e para o cálculo das variáveis-chave identificadas no diagrama de laço causal, mostrado anteriormente (seção 4.7.2). Sendo assim, a Tabela 4.12 apresenta, a partir dos documentos de registro, quais os dados coletados e as informações que podem ser consolidadas.

Tabela 4.12 Dados coletados por documento de registro

\begin{tabular}{|c|c|c|}
\hline Documentos de Registro & Dados Coletados & Informações Consolidadas \\
\hline $\begin{array}{l}\text { 1.1 Registro de Leilões e } \\
\text { Venda de Veículos }\end{array}$ & & $\begin{array}{l}\text { - lista de instrumentos de } \\
\text { divulgação de leilões e venda de } \\
\text { veículos para desmontagem } \\
\text { - frequência de atualização dos } \\
\text { instrumentos listados }\end{array}$ \\
\hline $\begin{array}{l}1.2 \text { Registro de Análise de } \\
\text { Veículos }\end{array}$ & $\begin{array}{l}\text { - dados do veículo analisado } \\
\text { - dados do leilão ou do local de venda } \\
\text { do veículo analisado } \\
\text { - parecer da análise da documentação } \\
\text { do veículo } \\
\text { - parecer da análise das condições } \\
\text { técnicas do veículo }\end{array}$ & $\begin{array}{l}\text { - total de veículos analisados } \\
\text { - taxa de veículos com } \\
\text { documentação regularizada } \\
\text { - taxa de veículos com boas } \\
\text { condições técnicas }\end{array}$ \\
\hline $\begin{array}{l}1.3 \text { Lista de } \quad \text { Peças } \\
\text { Possivelmente } \\
\text { Reutilizáveis }\end{array}$ & $\begin{array}{l}\text { - peças possivelmente reutilizáveis do } \\
\text { veículo }\end{array}$ & $\begin{array}{l}\text { - lista de peças mais recorrentes } \\
\text { como possivelmente reutilizáveis }\end{array}$ \\
\hline $\begin{array}{l}\text { 1.4 Contrato de Aquisição } \\
\text { de Veículo }\end{array}$ & $\begin{array}{l}\text { - dados do veículo (proprietário, } \\
\text { montadora, modelo, placa, } \\
\text { RENAVAM) } \\
\text { - valor do veículo adquirido } \\
\text { - local de origem do veículo } \\
\text { - data de aquisição } \\
\text { - data de saída do local de origem }\end{array}$ & $\begin{array}{l}\text { - taxa de veículos adquiridos fora } \\
\text { do DF } \\
\text { - valor médio de aquisição dos } \\
\text { veículos em fim de vida } \\
\text { - local de origem mais recorrente }\end{array}$ \\
\hline $\begin{array}{l}\text { 2.1 Ficha de Recebimento } \\
\text { de Veículo }\end{array}$ & $\begin{array}{l}\text { - data de recebimento no destino do } \\
\text { veículo } \\
\text { - horário de início da verificação para } \\
\text { recebimento } \\
\text { - horário de término da verificação para } \\
\text { recebimento } \\
\text { - parecer da verificação para } \\
\text { recebimento do veículo } \\
\text { - data da solicitação do Certificado de } \\
\text { Baixa do veículo }\end{array}$ & $\begin{array}{l}\text { - tempo de trajeto } \\
\text { - tempo de verificação } \\
\text { recebimento } \\
\text { - taxa de aprovação da } \\
\text { verificação do veículo }\end{array}$ \\
\hline $\begin{array}{lcll}2.2 & \text { Nota } & \text { Fiscal } & \text { de } \\
\text { Recebimento } & & \end{array}$ & $\begin{array}{l}\text { - número da nota fiscal de recebimento } \\
\text { do veículo }\end{array}$ & \\
\hline
\end{tabular}


(continuação da Tabela 4.12)

\begin{tabular}{|c|c|c|}
\hline Documentos de Registro & Dados Coletados & Informações Consolidadas \\
\hline $\begin{array}{l}\text { 3.1 Plano de Despoluição e } \\
\text { Desmontagem }\end{array}$ & $\begin{array}{l}\text { - orientações para despoluição e } \\
\text { desmontagem, específicas para o } \\
\text { veículo, com base no modelo }\end{array}$ & \\
\hline $\begin{array}{l}3.2 \text { Certificado de Baixa do } \\
\text { Veículo }\end{array}$ & $\begin{array}{l}\text { - data de obtenção do Certificado de } \\
\text { Baixa do veículo }\end{array}$ & $\begin{array}{l}\text { - tempo de emissão da baixa do } \\
\text { veículo }\end{array}$ \\
\hline $\begin{array}{l}\text { 4.1 Ficha de Despoluição de } \\
\text { Veículo }\end{array}$ & $\begin{array}{l}\text { - horário de início da despoluição } \\
\text { - horário de término da despoluição } \\
\text { - volume dos fluidos recolhidos }\end{array}$ & $\begin{array}{l}\text { - produtividade dos recursos } \\
\text { despoluição } \\
\text { - quantidade de volume médio de } \\
\text { fluidos no centro de } \\
\text { reaproveitamento } \\
\text { - espaço necessário para } \\
\text { armazenamento de fluidos }\end{array}$ \\
\hline $\begin{array}{l}\text { 5.1 Ficha de Desmontagem } \\
\text { de Veículo }\end{array}$ & $\begin{array}{l}\text { - horário de início da desmontagem } \\
\text { - horário de término da desmontagem } \\
\text { - quantidade de peças desmontadas }\end{array}$ & $\begin{array}{l}\text { - produtividade dos recursos } \\
\text { desmontagem }\end{array}$ \\
\hline $\begin{array}{ll}6.1 & \text { Procedimentos } \\
\text { Verificação } & \text { Qualidade das } \\
\text { Peças } & \end{array}$ & & $\begin{array}{l}\text { - requisitos de qualidade para } \\
\text { reutilização peças } \\
\text { - verificações capazes de atestá-las } \\
\text { e os seus níveis de aceitação }\end{array}$ \\
\hline $\begin{array}{l}6.2 \text { Ficha de Análise } \\
\text { Técnica da Qualidade }\end{array}$ & $\begin{array}{l}\text { - horário de início da análise técnica da } \\
\text { qualidade } \\
\text { - horário de término da análise técnica } \\
\text { da qualidade } \\
\text { - quantidade de peças analisadas } \\
\text { - parecer de classificação das peças } \\
\text { desmontadas em reutilizáveis, não } \\
\text { reutilizáveis ou passíveis de } \\
\text { reutilização } \\
\text { - horário de início do tratamento das } \\
\text { peças passíveis de reutilização } \\
\text { - horário de término do tratamento das } \\
\text { peças passíveis de reutilização } \\
\text { - parecer de classificação das peças } \\
\text { tratadas em reutilizáveis ou não } \\
\text { reutilizáveis } \\
\text { - parecer da estratégia de } \\
\text { gerenciamento para não reutilizáveis }\end{array}$ & $\begin{array}{l}\text { - produtividade dos recursos da } \\
\text { análise técnica } \\
\text { - taxa de aprovação da } \\
\text { desmontagem } \\
\text { - taxa de reprovação da } \\
\text { desmontagem } \\
\text { - taxa passíveis de reutilização } \\
\text { - produtividade dos recursos do } \\
\text { tratamento } \\
\text { - taxa de aprovação tratamento } \\
\text { - taxa de reprovação tratamento } \\
\text { - histórico de peças } \\
\text { encaminhadas para estratégia de } \\
\text { gerenciamento }\end{array}$ \\
\hline $\begin{array}{l}6.3 \text { Laudos Técnico e } \\
\text { Complementar }\end{array}$ & $\begin{array}{l}\text { - descrição do processo de } \\
\text { reaproveitamento do veículo }\end{array}$ & \\
\hline $\begin{array}{l}7.1 \text { Endereço de Peça no } \\
\text { Estoque }\end{array}$ & $\begin{array}{l}\text { - entrada e endereço de peças } \\
\text { reutilizáveis }\end{array}$ & - estoque de peças reutilizáveis \\
\hline $\begin{array}{l}8.1 \text { Ficha de Controle de } \\
\text { Vendas }\end{array}$ & $\begin{array}{l}\text { - data de divulgação peça reutilizável } \\
\text { no e-commerce } \\
\text { - número de clientes que procuraram o } \\
\text { e-commerce } \\
\text { - número de clientes atendidos pelo } \\
\text { centro no e-commerce } \\
\text { - número de clientes que procuraram o } \\
\text { centro em venda direta } \\
\text { - número de clientes atendidos pelo } \\
\text { centro em venda direta } \\
\text { - peças vendidas } \\
\text { - valor de venda da peça }\end{array}$ & $\begin{array}{l}\text { - demanda de peças reutilizáveis } \\
\text { no centro } \\
\text { - nível de serviço do centro } \\
\text { - histórico de peças vendidas } \\
\text { - giro médio do estoque } \\
\text { - valor médio de venda das peças }\end{array}$ \\
\hline 8.2 Nota Fiscal de Saída & $\begin{array}{l}\text { - número da nota fiscal de saída do } \\
\text { veículo }\end{array}$ & \\
\hline
\end{tabular}


Parte das informações consolidadas, mostradas na Tabela 4.12 estão em destaque porque representam as variáveis-chave identificadas no diagrama de laço causal e que, em pesquisas futuras, podem contribuir para a utilização de uma ferramenta de simulação no aprimoramento do modelo (estágios posteriores). Por isso, elas são descritas de forma mais detalhada a seguir na Tabela 4.13. 
Tabela 4.13 Descrição e fórmula de informações consolidadas

\begin{tabular}{|c|c|c|}
\hline Descrição da Informação Consolidade & Fórmula de Cálculo & \# \\
\hline \multicolumn{3}{|c|}{ Taxa de veículos com documentação regularizada e em boas condições técnicas } \\
\hline \multirow{4}{*}{$\begin{array}{l}\text { O documento de Registro de Análise de Veículos arquiva os dados } \\
\text { sobre a pesquisa que é realizada pelo centro de reaproveitamento para } \\
\text { aquisição de veículos leves em fim de vida útil. A partir deste registro } \\
\text { de todos os veículos analisados, é possível calcular a taxa de veículos } \\
\text { com documentação regularizada e a de veículos em boas condições } \\
\text { técnicas, conforme mostram as Equações } 4.1 \text { e } 4.2 \text {, respectivamente. } \\
\text { Sabe-se que essas taxas são apenas para o centro de reaproveitamento } \\
\text { na qual a coleta de dados será realizada, mas elas já podem indicar } \\
\text { uma estimativa em relação às do mercado como um todo. }\end{array}$} & \multirow{2}{*}{ Taxa de veículos com doc. regularizada $=\frac{\text { Total de veículos com doc. regularizada }}{\text { Total de veículos analisados }}$} & \multirow{2}{*}{$(4.1)$} \\
\hline & & \\
\hline & \multirow{2}{*}{ Taxa de veículos com boas cond. técnicas $=\frac{\text { Total de veículos com boas cond. técnicas }}{\text { Total de veículos analisados }}$} & \multirow{2}{*}{$(4.2)$} \\
\hline & & \\
\hline \multicolumn{3}{|l|}{ Taxa de veículos adquiridos fora do Distrito Federal } \\
\hline $\begin{array}{l}\text { Do total de veículos adquiridos, parte tem o local de origem fora do } \\
\text { Distrito Federal. Isso ocasiona impactos que podem, inclusive, } \\
\text { inviabilizar a obtenção do veículo em fim de vida útil. A partir do local } \\
\text { de origem contido no documento de Contrato de Aquisição de Veículo } \\
\text { de todos os veículos adquiridos, é possível calcular a Taxa de veículos } \\
\text { adquiridos fora do Distrito Federal de acordo com a Equação 4.3. }\end{array}$ & Taxa de veículos adquiridos fora do $\mathrm{DF}=\frac{\text { Total de veículos adquiridos fora do DF }}{\text { Total de veículos adquiridos }}$ & $(4.3)$ \\
\hline \multicolumn{3}{|l|}{ Tempo de trajeto } \\
\hline $\begin{array}{l}\text { É interessante conhecer o tempo de trajeto do transporte de um veículo } \\
\text { para, em estágios posteriores, o centro de reaproveitamento poder } \\
\text { realizar atividades de planejamento e controle da produção, a partir do } \\
\text { prazo para chegada de um veículo comprado em determinada } \\
\text { localidade. Ele pode ser calculado pela subtração da data de } \\
\text { recebimento do veículo no destino pela data de saída do local de } \\
\text { origem (Equação 4.4), dados contidos nos respectivos documentos: } \\
\text { Ficha de Recebimento de Veículo e Contrato de Aquisição de Veículo. }\end{array}$ & Tempo de trajeto de transporte $=$ Data de recebimento no destino - Data de saída da origem & $(4.4)$ \\
\hline \multicolumn{3}{|l|}{ Tempo e taxa de aprovação da verificação de recebimento } \\
\hline \multirow[b]{2}{*}{$\begin{array}{l}\text { A primeira tarefa da atividade de recebimento é a verificação do } \\
\text { veículo e da sua documentação em relação ao Contrato de Aquisição } \\
\text { de Veículo. Ela é realizada com a Lista de Peças Possivelmente } \\
\text { Reutilizáveis. Na Ficha de Recebimento de Veículo, então, são } \\
\text { registrados os dados de início e término dessa verificação, bem como o } \\
\text { seu parecer (aprovado ou reprovado). Sendo assim, é possível calcular } \\
\text { o tempo de verificação e a taxa de aprovação dessa verificação de } \\
\text { acordo com as Equações } 4.5 \text { e } 4.6 \text {, respectivamente. }\end{array}$} & Tempo da verificação do recebimento = Término da verificação - Início da verificação & $(4.5)$ \\
\hline & Taxa de aprovação da verificação do receb. $=\frac{\text { Total de veículos aprovados na verificação }}{\text { Total de veículos verificados }}$ & $(4.6)$ \\
\hline
\end{tabular}


O tempo de emissão do Certificado de Baixa do Veículo pelo DETRAN-DF será calculado através da diferença da data da solicitação do Certificado de Baixa do veículo registrada na Ficha de Recebimento de Veículo e da data de obtenção do Certificado de Baixa do veículo, expressa no próprio documento, conforme a Equação 4.7. Esse tempo é importante tendo em vista que obriga o centro de reaproveitamento a permanecer com o veículo estocado, visto que é proibido desmontar veículos que não possuam esse documento.

\section{proibido desmontar veículos que não possuam esse documento. \\ Produtividade dos recursos de despoluição, desmontagem, análise técnica e tratamento}

As produtividades dos recursos das atividades de transformação -

despoluição, desmontagem, análise técnica e tratamento - podem ser calculadas tendo em vista a quantidade de veículos ou peças que eles conseguem processar por unidade de tempo determinada, obtida das Fichas de Despoluição, de Desmontagem e de Análise Ténica da Qualidade de Veículo. A consolidação desses dados pode contribuir com a avaliação de custo e benefício que o modelo sugere que seja feita para a aplicação das técnicas de renovação, reparação, recondicionamento e de novos testes de verificação da qualidade.

\section{Taxas de aprovacão, de reprovação; de peças passíveis de reutilização da desmontagem}

A análise da qualidade prevê um documento chamado Ficha de Análise Técnica da Qualidade do Veículo, na qual são registrados as quantidades de peças e os pareceres de classificação após a realização dos testes de verificação da qualidade, bem como os dados similares referentes à aplicação das técnicas de tratamento nas peças passíveis de reutilização. As taxas de aprovação, reprovação e de peças passíveis de reutilização da desmontagem podem ser calculadas de acordo com as Equações 4.9, 4.10 e 4.11. Observa-se que elas são complementares e, portanto, o somatório delas é igual a 1.

\section{Taxa de aprovação do tratamento}

Considera apenas as peças passíveis de reutilização que passaram por tratamento (renovação, reparação, recondicionamento) e, então, novos testes de verificação da qualidade foram realizados para classificação definitiva em peças reutilizáveis (aprovadas) ou não reutilizáveis (reprovadas). O raciocínio de cálculo utilizado é similar ao anterior,

Produtividade dos recursos $=\quad$ Total de veículos ou peças transformados Tempo determinado dos recursos de transformação Taxa de aprovação da desmontagem $=\frac{\text { Total de peças aprovadas na desmontagem }}{\text { Total de peças retiradas de veículos }}$

Taxa de reprovação da desmontagem $=\frac{\text { Total de peças reprovadas na desmontagem }}{\text { Total de }}$ Total de peças retiradas de veículos

Taxa peças passíveis de reutilização =1-Taxa aprovação-Taxa reprovação desmontagem
Taxa de aprovação do tratamento $=\frac{\text { Total de peças aprovadas após tratamento }}{\text { Total de peças passíveis de reutilização }}$

Taxa de reprovação do tratamento $=1$ - Taxa de aprovação do tratamento 
(continuação da Tabela 4.13)

\section{Demanda de peças reutilizáves do centro, histórico de peças reutilizáveis vendidas e nível de serviço do centro}

A demanda total de peças reutilizáveis existente no Distrito Federal é

uma variável exógena ao centro de reaproveitamento, entretanto, a sua parcela específica pode ser estimada a partir do número de clientes que o procuraram, seja pelo e-commerce ou pela venda direta. Esse dado é registrado na Ficha de Controle de Vendas (Tabela 4.12).

Já as peças reutilizáveis vendidas, registradas no mesmo documento e confirmadas pela emissão da nota fiscal, indicam a parte da demanda que procurou o centro de reaproveitamento e foi atendida. A partir destas duas informações é possível calcular o nível de serviço do centro, conforme a Equação 4.14 indica.

\section{Estoque de peças reutilizáveis e giro de estoque do centro}

As peças reutilizáveis em estoque são registradas no documento de

Endereço de Peça no Estoque, desde o armazenamento até que sejam vendidas. Pode ser que essa informação sinalize um grupo de materiais que simplesmente não é procurado. Nesse caso, orienta-se que outras estratégias de gerenciamento sejam selecionadas a ele.

A partir desse dado é possível calcular o estoque médio de peças por determinado período de tempo e, consequentemente, com a informação do número de peças vendidas no mesmo tempo, o giro de estoque do centro de reaproveitamento (Equação 4.15). Esses dados são diretamente utilizados para a tomada de decisão sobre a aquisição ou não de veículos em fim de vida como matéria-prima.

Esse conhecimento permite que o empresário atente-se à formação de estoque e não imobilize recursos em estoque nos períodos de baixa

demanda, por exemplo.

\section{Peças encaminhadas para estratégia de gerenciamento}

A informação sobre as peças não reutilizáveis encaminhadas para a estratégia de gerenciamento é obtida da Ficha de Análise Técnica da Qualidade, que registra a definição da estratégia a ser tomada para as peças dessa classificação. A determinação do volume desse tipo de material é importante para posterior fortalecimento da cadeia de reaproveitamento, visto que pode comprovar a existência de demanda para empresas de reciclagem, recuperação ou destinação final adequada.

do


Sobre o controle das informações de uma maneira geral, não foi a intenção desta dissertação esgotar as orientações sobre as melhores alternativas para o centro de reaproveitamento, mas apenas dar direcionamentos aos interessados em implementar o modelo proposto e aos trabalhos futuros. Inclusive, uma das propostas para próximas pesquisas é justamente a modelagem dos sistemas de informação relacionados ao centro.

De toda forma, uma última consideração merece destaque e ela diz respeito à integração entre os sistemas de informação. Tudo o que foi proposto é com o intuito de melhorar o gerenciamento da sua operação, entretanto, os objetivos do DETRAN-DF são outros, relacionados à fiscalização de determinadas atividades. Sendo assim, pode ser que nem todas as informações coletadas precisem ser registradas no sistema de informação do órgão executivo de trânsito.

Nesse contexto, ressalta-se a importância de integração entre os sistemas, para que os dados registrados no sistema de controle operacional necessários ao DETRAN-DF sejam simplesmente encaminhados, sem qualquer atividade repetitiva de digitação. Por isso, o orienta-se que o sistema do próprio centro de reaproveitamento seja escolhido de acordo com a sua possibilidade de comunicação com o do órgão executivo de trânsito.

A Figura 4.15 ilustra brevemente a integração esperada entre o sistema de controle operacional próprio, no qual são inseridos os dados dos documentos preenchidos no processo de reaproveitamento de veículos leves em fim de vida útil e o sistema de fiscalização do DETRAN-DF.

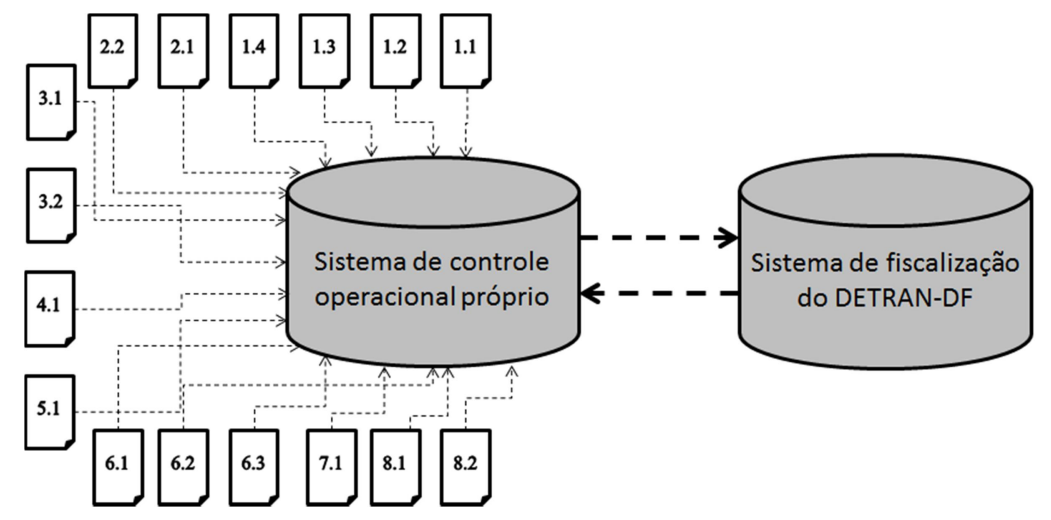

Figura 4.15 Integração dos sistemas de informação do centro de reaproveitamento proposto Dessa maneira, o controle das informações atende à característica primordial de integração, reforçada por Coelho, Gonzales-Taco e Fonseca (2016) quando analisaram o sistema de informação do DETRAN-SP. 


\section{CONCLUSÕES GERAIS E RECOMENDAÇÕES PARA PESQUISAS FUTURAS}

Essa dissertação de mestrado propôs um modelo de centro de reaproveitamento de veículos leves em fim de vida útil, com definição de atividades, documentos, equipamentos, pessoas e arranjo físico, tendo em vista as boas práticas internacionais e nacionais, a regulamentação aplicável e o contexto das empresas do Distrito Federal.

A execução da pesquisa foi orientada conforme o método apresentado na seção 1.4, não havendo ponderações ou ocorrências que inviabilizaram a sua aplicação, respondendo à pergunta de pesquisa exposta em 1.1 e atingindo os objetivos propostos em 1.2. Dessa maneira, são apresentadas a seguir as principais conclusões obtidas, bem como as recomendações para trabalhos futuros.

\subsection{CONCLUSÕES GERAIS}

A pesquisa contribuiu para o conhecimento do reaproveitamento de veículos leves em fim de vida útil, principalmente no contexto brasileiro e do Distrito Federal. Com o panorama explicitado a partir de pesquisa bibliográfica realizada para obtenção das boas práticas internacionais e de pesquisas de campo para compreensão das realidades do estado de São Paulo e do Distrito Federal, foi possível identificar a posição do país e do próprio Distrito Federal em relação ao desenvolvimento dessa linha de pesquisa ao longo dos anos.

Primeiramente, foi destacada a importância de uma legislação específica para o reaproveitamento de veículos em fím de vida útil para a mudança do estágio inicial das empresas do setor nos diferentes países. Além disso, algumas similaridades foram reconhecidas entre as regulamentações de referência: estabelecimento de requisitos para registro e operação de centros de reaproveitamento, definição de órgãos responsáveis pelo controle dessa atividade, proposição da utilização de um sistema de informação para rastreabilidade dos materiais e estabelecimento de programa de metas para estratégias de gerenciamento (reúso, renovação, reparação, recondicionamento, remanufatura, reciclagem, recuperação).

Nesse sentido, felizmente, o Brasil foi capaz de compreender a importância das experiências internacionais reconhecidas ao longo das últimas décadas como positivas e colocar parcela significativa delas na Lei 12.977/ 2014 e na Resolução CONTRAN 611/ 2016. Entretanto, não foi identificada a intenção no estabelecimento de metas de 
desempenho mensuráveis a serem atingidas pelos centros de reaproveitamento, acredita-se que em virtude da recente preocupação e da indisponibilidade de dados relacionados.

Ainda em relação às exigências da Lei 12.977/ 2014, é importante comentar que os órgãos executivos de trânsito foram selecionados como os principais fiscalizadores das operações dos centros de reaproveitamento. Nesse sentido, observou-se que alguns deles, em diferentes estados, já publicaram portarias complementares à lei federal, mas que a aplicação efetiva do registro das empresas habilitadas, por exemplo, apenas foi realizado pelo estado de São Paulo, que se coloca como pioneiro no contexto nacional.

No Distrito Federal, por outro lado, observa-se que o órgão executivo de trânsito (DETRAN-DF) ainda se encontra sem equipe especializada e direcionada para o levantamento das necessidades e para o acompanhamento da aplicação da legislação e, por isso, ainda não há orientação formal ou portarias sobre os próximos passos que serão dados dentro do setor na região. Tampouco os sindicatos relacionados conseguiram se organizar no sentido de amparar os empresários dos centros de reaproveitamento de veículos em fim de vida. E, por isso, o cenário é de desconhecimento sobre como as operações devem proceder.

No que diz respeito à estruturação da cadeia de reaproveitamento de veículos leves, foi observado que ela depende das situações econômicas e geográficas da localidade na qual se encontra. Em regiões nas quais ela é mais fortalecida, ocorre a participação de atores especializados nas diferentes estratégias de gerenciamento. Ao contrário, em locais com mercado ainda em desenvolvimento, pode haver menos possibilidades. As referências encontram-se na primeira alternativa, enquanto o Distrito Federal, na segunda.

O fortalecimento do mercado, além de dar mais alternativas de gerenciamento dos materiais, pode, inclusive, promover a cooperação entre os diferentes atores da cadeia de reaproveitamento, o que pode facilitar a estruturação das atividades internas do centro, como é o caso de duas iniciativas europeias que foram comentadas - o IMDS e o IDIS sistemas que disponibilizam um ambiente de troca de informação entre as montadoras, os centros, as recicladoras etc. Eles, portanto, disseminam o conhecimento sobre como realizar o reaproveitamento corretamente para os veículos de 1985 até hoje.

A ausência de contato entre os centros de reaproveitamento e as montadoras é crítica, tendo em vista que a falta de especialização dessas empresas as direcionam ao recebimento 
de veículos de marcas, modelos e anos de fabricação diferentes, dificultando o acompanhamento do conhecimento técnico necessário para todos eles e o sequenciamento adequado para a realização das operações de desmontagem. No Brasil, não foi observada qualquer iniciativa nesse sentido. A única cooperação ressaltada entre atores da cadeia de reaproveitamento foi a realizada entre a Renova Ecopeças e a Porto Seguros, mas é especificamente para o encaminhamento dos veículos sinistrados com perda total ou grande monta, para que sejam desmontados pelo centro de reaproveitamento de São Paulo.

A falta de colaboração no Distrito Federal é perceptível, inclusive, na forte resistência dos centros de reaproveitamento em discutirem possibilidades de cooperação entre eles para melhor atendimento das exigências impostas pela Lei 12.977/2014. Sendo assim, para que o modelo pudesse atingir à sua finalidade de atender à realidade do Distrito Federal, não puderam ser consideradas alternativas dessa natureza e as condições iniciais de tamanho, número de pessoas e capacidade tiveram que ser mantidas.

Dessa maneira, o modelo desenvolvido considerou como objeto de estudo as pequenas empresas (capacidade de processamento de 15 veículos por mês), sem regularização e estruturação, que realizam uma combinação de atividades relacionadas a veículos leves em fim de vida útil, sem a devida preocupação com os impactos ambientais provocados. Numa infraestrutura precária e desorganizada, em virtude dos estoques de veículos e de peças, e de áreas próximas à $200 \mathrm{~m}^{2}$, trabalham em torno de quatro colaboradores, sem capacitação formal, e baseados no conhecimento tácito adquirido com a experiência.

Essa realidade, identificada pela pesquisa de campo realizada, mostrou a impossibilidade de o Distrito Federal adotar um dos modelos internacionais ou nacionais, que são caracterizados pela alta capacidade de processamento de veículos, pela profissionalização dos colaboradores, pela disponibilidade de ferramentas de larga escala e de equipamentos especializados, pelo amplo espaço físico com projeto de arranjo físico próprio e pelo amplo uso de sistemas de informação para controle, fiscalização, rastreabilidade e integração.

Entretanto, é justamente nesse contexto que essa dissertação agrega valor exploratório ao conhecimento acadêmico, desenvolvendo um modelo que, apesar de aderente às legislações adequadas e às boas práticas utilizadas internacional e nacionalmente em empresas de referência, é acessível ao cotidiano e à realidade prática das empresas que caracterizam o Distrito Federal. Ademais, acredita-se que essas condições não sejam exclusividade da região analisada, mas que existam outras localidades similares no Brasil e 
que, por isso, ele pode proporcionar uma maior aceitabilidade da Lei 12.977/ 2014 pelo mercado, desde que com os devidos ajustes necessários.

No modelo proposto, foram definidas e estruturadas as atividades e as tarefas a serem desempenhadas pelo centro; os recursos humanos foram caracterizados em relação à capacitação e à divisão de funções e responsabilidades; foram sugeridos equipamentos, mesmo que sejam necessárias alternativas simples de mesma funcionalidade; e a tecnologia da informação exigida para o controle do centro foi descrita.

No que diz respeito à infraestrutura, foram delimitadas as possíveis localidades para desempenho das atividades, para o caso de novos interessados ou para confirmação das empresas já existentes. Em seguida, foram enfatizadas as áreas necessárias dentro do centro de reaproveitamento e, tendo as em vista, foi feita uma proposta preliminar de arranjo físico.

Sendo assim, acredita-se que partir das descrições feitas para o estágio inicial de cada um dos elementos comentados, as atuais empresas de reaproveitamento de veículos leves em fím de vida útil serão capazes de se adaptar e melhor realizar as suas operações, bem como de melhor atender à tendência de crescimento da demanda estimada no diagnóstico realizado. O órgão executivo de trânsito (DETRAN-DF) também terá maiores insumos para publicar portarias de orientação, registro, controle e fiscalização do setor.

De toda forma, é importante explicitar as limitações da pesquisa realizada. Primeiramente, tendo em vista que não há previsão de incentivo ou fomento por parte do governo distrital para melhoria dos centros de reaproveitamento de veículos leves em fim de vida útil, uma limitação do modelo foi não ter realizado o estudo de viabilidade econômica e financeira da planta industrial proposta. Entretanto, tendo em vista as mudanças incentivadas, mais focadas na melhoria da operação e da gestão que em investimentos, acredita-se que elas podem ser realizadas a partir dos recursos próprios dos centros.

Também, a indisponibilidade de dados devido à falta de registro das operações nos centros de reaproveitamento e à dificuldade para coleta desses dados por parte do pesquisador tendo em vista o ambiente inóspito e insalubre do mercado analisado, provocou com que as decisões fossem tomadas de acordo com o julgamento do pesquisador em relação à realidade observada na pesquisa de campo e às boas práticas levantadas. Nesse sentido, é preciso a validação do modelo, por parte de especialistas e por análise prática, para que ele 
possa ser confirmado como adequado. O prazo para finalização da dissertação não permitiu que essas ações fossem realizadas.

Justamente em virtude da limitação provocada pela ausência de dados, o modelo proposto elaborou o diagrama do laço causal para orientar os atores envolvidos a compreenderem as variáveis chaves, bem como o relacionamento entre elas, e a estrutura do problema. E, a partir dessa informação, realizarem o levantamento dos dados que permitam que a tomada de decisão nos próximos estágios seja quantitativa, contribuindo com a implementação e o aprimoramento gradual dos centros de reaproveitamento do Distrito Federal.

Dessa maneira, espera-se que o modelo proposto seja, no Distrito Federal, o princípio de um conjunto de ações que possibilitem o alcance dos principais benefícios que o melhor desempenho das atividades da cadeia de reaproveitamento de veículos leves em fim de vida útil pode proporcionar:

- extensão máxima do ciclo de vida dos materiais, impulsionando o descarte mínimo, consciente e adequado;

- fortalecimento do mercado de peças automotivas reutilizadas, tendo em vista a sua qualidade e a confiabilidade, bem como do seu processo de transformação;

- formalização do registro trabalhista e capacitação técnica das pessoas envolvidas com o reaproveitamento de veículos;

- redução dos crimes provocados pelo mercado ilegal de peças automotivas em virtude do controle e da fiscalização do mercado controlado;

- possibilidade de implementação do seguro popular para melhoria na manutenção dos veículos leves em circulação;

- redução de acidentes e poluição ocasionados por veículos com idade avançada, através de incentivos para renovação da frota em circulação.

\subsection{RECOMENDAÇÕES PARA PESQUISAS FUTURAS}

Sendo assim, percebe-se que ainda há necessidade de desenvolvimento e implementação de outras pesquisas para que os benefícios advindos do sistema de gerenciamento do reaproveitamento de veículos leves em fim de útil possam ser verificados. Sendo assim, são apresentadas algumas possibilidades para estudos futuros:

- avaliação de viabilidade econômica e financeira do modelo proposto; 
- proposição de plano de resíduos sólidos para o modelo proposto;

- validação do modelo proposto a partir da pesquisa com especialistas e da implementação em centros de reaproveitamentos já existentes do Distrito Federal;

- generalização do modelo para que o conhecimento gerado na realidade específica do Distrito Federal possa ser utilizado em outros estados com características semelhantes;

- proposição do próximo estágio do modelo, tendo em vista os resultados obtidos dos dados da operação, bem como de modelos de simulação aprofundados;

- proposição dos requisitos de qualidade para reutilização das peças automotivas, bem como das verificações capazes de atestá-los e dos níveis de aceitação, para auxiliar o CONTRAN na publicação de normas relacionadas;

- proposição de um programa de metas de desempenho a ser cumprido pelos centros de reaproveitamento e exigido pela legislação federal e pelos órgãos executivos de trânsito, como observado nas boas práticas internacionais;

- modelagem do sistema de informação que deve ser disponibilizado pelo DETRAN-DF, do que deve ser utilizado internamente nas empresas, bem como da integração existente entre eles e da forma de divulgação das informações para a sociedade;

- modelagem do programa de renovação da frota de veículos leves que incentive a entrega de veículos com idade avançada em centros de reaproveitamento para troca por veículos novos;

- modelagem da rede de logística reversa com fortalecimento da cadeia de reaproveitamento, a partir da definição da quantidade, da localização e do dimensionamento dos atores envolvidos. 


\section{REFERÊNCIAS BIBLIOGRÁFICAS}

AGRAWAL, S.; SINGH, R. K.; MURTAZA, Q. (2015) A literature review and perspectives in reverse logistics. Resources, Conservation and Recycling, v. 97, p.76-92.

AHMED, S.; AHMED, S.; SHUMON, M. R.; QUADER, M. A. (2014) End-of-Life Vehicles (ELVs) Management and Future Transformation in Malaysia. Applied Science and Agriculture, v. 9, n. 18, p. 227-237.

ANFAVEA. (2016) Anuário da Indústria Automobilística Brasileira. São Paulo, 2016. Em: < http://www.anfavea.com.br/anuario.html >. Acesso em 31 de março de 2016.

AZMI, M.; SAMAN, M. Z.; SHARIF, S.; ZAKUAN, N.; MAHMOOD, S. (2013) Proposed Framework for End-Of-Life Vehicle Recycling System Implementation in Malaysia. GCSM.EU, p. 188-194

BALLOU, R. H. (2006) Gerenciamento da cadeia de suprimentos/ logística empresarial. 5 ed. Porto Alegre: Bookman.

BERZI, L.; DELOGU, M.; GIORGETTI, A.; PIERINI, M. (2013) On-field investigation and process modelling of End-of-Life Vehicles treatment in the context of Italian craft-type Authorized Treatment Facilities. Waste Management, v. 33, n. 4, p. 892-906.

BRASIL. Decreto n. 1.305, de 9 de novembro de 1994. Regulamenta a Lei no 8.722, de 27 de outubro de 1993, que torna obrigatória a baixa de veículos vendidos como sucata e dá outras providências.

BRASIL. Decreto n. 7.404, de 23 de dezembro de 2010. Regulamenta a Lei no 12.305, de 2 de agosto de 2010, que institui a Política Nacional de Resíduos Sólidos, cria o Comitê Interministerial da Política Nacional de Resíduos Sólidos e o Comitê Orientador para a Implantação dos Sistemas de Logística Reversa, e dá outras providências.

BRASIL. Lei n. 5.452, de $1^{\circ}$ de maio de 1943. Aprova a Consolidação das Leis do Trabalho.

BRASIL. Lei n. 8.722, de 27 de outubro de 1993. Torna obrigatória a baixa de veículos vendidos como sucata e dá outras providências.

BRASIL. Lei n. 9.503, de 23 de setembro de 1997. Institui o Código de Trânsito Brasileiro.

BRASIL. Lei n. 12.305, de 2 de agosto de 2010. Institui a Política Nacional de Resíduos Sólidos; altera a Lei 9.605, de 12 de fevereiro de 1998; e dá outras providências.

BRASIL. Lei n. 12.977, de 20 de maio de 2014. Regula e disciplina a atividade de desmontagem de veículos automotores terrestres; altera o art. 126 da Lei 9503, de 23 de setembro de 1997 - Código de Trânsito Brasileiro; e dá outras providências.

CASTRO, D. E.; SOUZA, V. L. M.; BOVOLENTA, A. G.. (2012) Reciclagem e sustentabilidade na indústria automobilística. Belo Horizonte: [s.n.].

CAUCHICK, P.A. M. (2007) Estudo de caso na engenharia de produção: estruturação e 
recomendações para sua condução. Produção, v.17, n.1, p.216-229.

CHING, Y. H. (2006) Gestão de Estoques na Cadeia de Logística Integrada - supply chain. 3 ed. São Paulo: Atlas.

CNT. (2010) Relatório Completo do Seminário Internacional sobre Reciclagem de Veículos e Renovação de Frota: as experiências internacionais e os desafios brasileiros. Brasilia.

COELHO, L. L. G. A.; GONZALES-TACO, P. W.; FONSECA, A. P. (2016) Análise do sistema de informação da logística reversa de veículos em fim de vida útil proposto por legislação para o estado de São Paulo. XXX Congresso Nacional de Pesquisa em Transporte da ANPET. Logística, Sistema de Informação e Simulação em Logística. Rio de Janeiro.

COELHO, L. L. G. A.; MOURA, F. L. A.; ARRUDA, F. S.; FONSECA, A. P. (2016) Logística reversa de veículos em fim de vida útil no Distrito Federal: estudo na implantação de centro de reaproveitamento. XXX Congresso Nacional de Pesquisa em Transporte da ANPET. Logística, Sistema de Informação e Simulação em Logística. Rio de Janeiro.

CONSELHO FEDERAL DE ENGENHARIA, ARQUITETURA E AGRONOMIA CONFEA. Resolução n. 458, de 27 de abril de 2001. Dispõe sobre a fiscalização do exercício profissional referente à inspeção técnica de veículos, automotores e rebocados, e das condições de emissão de gases poluentes e de ruído por eles produzidos.

CONSELHO NACIONAL DE SEGUROS PRIVADOS - CNSP. Resolução n. 336, de 31 de março de 2016. Dispõe sobre as regras e os critérios para operação do seguro popular de automóvel com permissão de utilização de peças usadas oriundas de empresas de desmontagem, conforme lei específica, para a recuperação de veículos sinistrados com cobertura securitária, e dá outras providências.

CONSELHO NACIONAL DE TRÂNSITO - CONTRAN. Resolução n. 11, de 23 de janeiro de 1998. Estabelece critérios para a baixa de registro de veículos a que se refere bem como os prazos para efetivação.

CONSELHO NACIONAL DE TRÂNSITO - CONTRAN. Resolução n. 113, de 5 de maio de 2000. Acrescentar $\S 4^{\circ}$ ao artigo $1^{\circ}$ da Resolução $n^{\circ} 11 / 98$ - CONTRAN.

CONSELHO NACIONAL DE TRÂNSITO - CONTRAN. Resolução n. 179, de 7 de julho de 2005. Estabelece a revisão de procedimentos para a baixa de registro de veículos conforme o disposto no art. 126 do Código de Trânsito Brasileiro - CTB e na Resolução CONTRAN no $11 / 98$.

CONSELHO NACIONAL DE TRÂNSITO - CONTRAN. Resolução n. 530, de 14 de maio de 2015. Regulamenta a Lei $\mathrm{n}^{\circ} 12.977$, de 20 de maio de 2014 , que regula e disciplina a atividade de desmontagem de veículos automotores terrestres.

CONSELHO NACIONAL DE TRÂNSITO - CONTRAN. Resolução n. 611, de 24 de maio de 2016. Regulamenta a Lei $n^{\circ} 12.977$, de 20 de maio de 2014 , que regula e disciplina a atividade de desmontagem de veículos automotores terrestres, altera o $\S 4^{\circ}$ do art. $1^{\circ}$ da Resolução CONTRAN n 11 , de 23 de janeiro de 1998, e dá outras providências. 
CONSELHO NACIONAL DO MEIO AMBIENTE - CONAMA. Resolução n. 401, de 4 de novembro de 2008. Estabelece os limites máximos de chumbo, cádmio e mercúrio para pilhas e baterias comercializadas no território nacional e os critérios e padrões para o seu gerenciamento ambientalmente adequado, e dá outras providências.

COUNCIL OF SUPPLY CHAIN MANAGEMENT PROFESSIONALS. Supply chain management terms and glossary: updated August 2013. Em: $\mathrm{http} / / / \mathrm{cscmo.org} / \mathrm{imis} 0 / \mathrm{CSCMP} /$ Educate/SCM_Definitions_and_Glossary_of_Terms/CSC MP/Educate/SCM_Definitions_and_Glossary_of_Terms.aspx?hkey=6087958 8 -f65f-4ab5$8 \mathrm{c} 4 \mathrm{~b}-6878815 \mathrm{ef} 921$. Acesso em 21 de dezembro de 2016.

CRUZ-RIVERA, R. (2008) Implementation of End-of-Life-Vehicle's Recycling for Developing Countries: Case Study, Mexico. Tese de Doutorado. Faculdade de Engenharia e Ciências Ambientais. Brandernburg Technical University Cottbus.

CRUZ-RIVERA, R.; ERTEL, J. (2009) Reverse logistics network design for the collection of End-of-Life Vehicles in Mexico. European Journal of Operational Research, v. 196, n. 3, p. 930-939.

DAUGHERTY, P. J.; MYERS, M; RICHEY R. (2002) Information support forreverse logistics: the influence of relationship commitment. J Bus Logist 23(1):85-106.

DENATRAN. (2015) Frota nacional. Em: $<$ http://www.denatran.gov.br/frota2015.htm $>$. Acesso em 10 de março de 2016.

DENG Y. (2004) Obstacle for reverse logistics and decision-makingcirculation analysis. Mod Logist 2:4-6.

DETRAN-GO. Portaria n. 345, de 21 de maio de 2015. Suspende o credenciamento de empresas para executarem atividades de desmontagem de veículos automotores terrestres e/ou para comercializarem peças ou acessórios usados ou recondicionados provenientes do desmonte e dá outras providências.

DETRAN-MS. Portaria n. 25, de 6 de agosto de 2015. Dispõe sobre o credenciamento de empresas que pretendem atuar no ramo de desmontagem e destinação das peças usadas de veículos automotores e dá outras providências.

DETRAN-PR. Portaria n. 165, de 5 de abril de 2016.

DETRAN-RS. Portaria n. 184, de 11 de maio de 2015.

DETRAN-SC. Portaria n. 622, de 2 de maio de 2016.

DETRAN-SP. Portaria n. 510, de 16 de novembro de 2015. Estabelece normas pertinentes ao registro de empresas estabelecidas no ramo de reciclagem e desmontagem de veículos e de comercialização de suas partes e peças junto ao Departamento Estadual do Trânsito e dá outras providências.

DETRAN-TO. Portaria n. 859, de 20 de novembro de 2015. Dispõe sobre a regulamentação do credenciamento e renovação do recredenciamento e define os critérios para o registro e atuação das empresas de desmontagem de veículos automotores terrestres,comércio de peças de veículos baixados, reciclados, sucatas e ferro velhona área 
de jurisdição do Departamento Estadual de Trânsito do Estado do Tocantins/DETRANTO,com supedâneo no que dispõe a Resolução CONTRAN n ${ }^{0}$ 530/2015 e Lei Federal no $12.977 / 2014$.

DISTRITO FEDERAL. Lei n. 2.105, de 8 de outubro de 1998. Dispõe sobre o Código de Edificações do Distrito Federal.

DISTRITO FEDERAL. Projeto de Lei Complementar n. 79, de 26 de setembro de 2013. Aprova a Lei de Uso e Ocupação do Solo do Distrito Federal - LUOS, nos termos dos arts. 316 e 318 da Lei Orgânica do Distrito Federal, e dá outras providências.

DRESCH, A; LACERDA, D. P.; ANTUNES, J. A. V. (2015) Design science research: método de pesquisa para avanço da ciência e tecnologia. Porto Alegre: Bookman.

ENE, S.; ÖZTÜRK, N. (2015) Network modeling for reverse flows of end-of-life vehicles. Waste Management, v. 38, n. 1, p. 284-296.

ESPÍRITO SANTO. Lei n. 10.031, de 6 de junho de 2013. Disciplina o cadastramento de estabelecimento destinado ao corte ou ao desmonte de veículos automotores terrestres e na comercialização de autopeças usadas, reparadas e recondicionadas, de partes de veículos automotores terrestres e de sucatas ou ferrovelho e dá outras providências.

GAN, J. W.; HE, Z. G. (2014) Literature Review and Prospect on the End-of-Life Vehicles Reverse Logistics. Advanced Materials Research, v. 878, p. 66-74.

GERRARD, J.; KANDLIKAR, M. (2007) Is European end-of-life vehicle legislation living up to expectations? Assessing the impact of the ELV Directive on "green" innovation and vehicle recovery. Journal of Cleaner Production, v. 15, n. 1, p. 17-27.

GHK. (2016) A study to examine the benefits of the End of Life Vehicles Directive and the costs and benefits of a revision of the 2015 targets for recycling, reuse and recovery under the VFV Directive. Disponível em: $<$ http://ec.europa.eu/environment/waste/pdf/study/final_report.pdf $>$ Acesso em: 30 maio de 2016.

GIL, A. C. (2010) Como elaborar projetos de pesquisa. 5 ed. São Paulo: Atlas.

GO, T. F.; WAHAB, D. A.; RAHMAN, M. N.; RAMLI, R.; AZHARI, C. H. (2011) Disassemblability of end-of-life vehicle: A critical review of evaluation methods. Journal of Cleaner Production, v. 19, n. 13, p. 1536-1546.

GO, T. F.; WAHAB, D. A.; RAHMAN, M. N.; RAMLI, R.; HUSSAIN, A. (2012) Genetically optimised disassembly sequence for automotive component reuse. Expert Systems with Applications, v. 39, n. 5, p. 5409-5417.

GOŁĘBIEWSKI, B.; TRAJER, J.; JAROS, M.; WINICZENKO, R. (2013) Modelling of the location of vehicle recycling facilities: A case study in Poland. Resources, Conservation and Recycling, v. 80, n. 1, p. 10-20.

GOMES, D. E. B. (2001) Estudo sobre a reciclagem na indústria automotiva e sua inserção em um ambiente virtual de ensino. In: Jornada de Iniciação Científica, 09. Rio de Janeiro. Anais Rio de Janeiro: CETEM/MCT. 
GONTIJO, J. (2016) Carro velho para reciclagem será crédito para comprar novo: Programa do governo e do setor quer tirar de circulação veículos leves com mais de 15 anos. Disponível em: <http://www.otempo.com.br/capa/economia/carro-velho-parareciclagem-será-crédito-para-comprar-novo-1.1207728>. Acesso em: 30 mai. 2016.

GUNGOR, A.; GUPTA, S. M. (1997) An evaluation methodology for disassembly processes. Computers \& Industrial Engineering, v. 33, n. 1-2, p. 329-332.

HARRAZ, N. A.; GALAL, N. M. (2011) Design of Sustainable End-of-life Vehicle recovery network in Egypt. Ain Shams Engineering Journal, v. 2, n. 3-4, p. 211-219.

INGHELS, D.; DULLAERT, W.; RAA, B.; WALTHER, G. (2016) Influence of composition, amount and life span of passenger cars on end-of-life vehicles waste in Belgium: A system dynamics approach. Transportation Research Part A: Policy and Practice, v. 91, p. 80-104.

LAMBERT, S.; RIOPEL, D.; ABDUL-KADER, W. (2011) A reverse logistics decisions conceptual framework. Computers and Industrial Engineering, 61(11), $561-581$.

LANGNAU, L. (2001) Winning with returns. Material Handling Management, 56(3), MHS13-MHS14.

LEITE, P. R. (2009) Logística reversa: meio ambiente e competitividade. São Paulo: Person Prentice Hall.

MANSOUR, S.; ZAREI, M. (2010) Designing a reverse logistics network for end-of-life vehicles recovery. Mathematical Problems in Engineering, v. 2010.

MATHIEUX, F.; FROELICH, D.; MOSZKOWICZ, P.. (2008) ReSICLED: a new recovery-conscious design method for complex products based on a multicriteria assessment of the recoverability. Journal of Cleaner Production, v. 16, n. 3, p. 277-298.

MEDINA, H.; GOMES, D. E. B.(2002) A indústria automobilística projetando para a reciclagem. $5^{\circ}$ Congresso Nacional de Pesquisa e Desenvolvimento em Design. Universidade de Brasília.

MEDINA, H.; NAVEIRO, R. (2009) Eco-design practices in Europe fostering automotive vehicles recyclability in Brazil. Product: Management \& Development, v. 7, n. June, p. $81-90$.

MEDINA, H.; NAVEIRO, R. M.; MALAFAIA, A. J. (2007) Design for Recycling Improving Environmental Performance of Automotive Industry in Brazil. International Conference on Engineering Design. Paris, France.

MERKISZ-GURANOWSKA, A. (2011) End-of-life vehicles recycling network design. Journal of KONES, v. 18, n. 3, p. 261-268.

MILDEMBERGER, L. (2012) Avaliação dos principais aspectos da reciclagem de veículos em fim de vida: comparação dos procedimentos legais, técnicos e administrativos entre Alemanha e Brasil. Dissertação de Mestrado Profissional. Programa de Pós Graduação em Meio Ambiente Urbano e Industrial. SENAI - PR. Curitiba. 
MILDEMBERGER, L.; NEUFFER, D.; PONTE, H. A.; FISCHER, K. (2015) Avalição de uma proposta de reciclagem de veículos em fim de vida no Paraná baseada no modelo alemão. REVISTA NEP (Núcleo de Estudos Paranaenses), v. 1, n. 1, p. 237-251.

MONTEIRO, J. H. P. et al. (2001) Manual de gerenciamento integrado de resíduos sólidos. Rio de Janeiro: IBAM.

MONTEIRO, M. J.; GLYCÉRIO, C. M.; SANTOS, R. C. L.; ARRUDA, F. S.; FONSECA, A. P. (2015) The challenges of reverse logistics management of end-of-life vehicles in Brazil. Business and Management Review, v.4,Special Issue, p.344-352.

NEUFERT, E. (2013) Arte de projetar em arquitetura. Tradução Benelisa Franco. 18 ed. São Paulo: Gustavo Gili.

NOVAES, A. (2015) Logística e gerenciamento da cadeia de distribuição. 4 ed. Rio de Janeiro: Elsevier.

PARLAMENTO EUROPEU. Diretiva n. 2000/ 53/ CE, de 18 de setembro de 2000. Relativa aos veículos em fim de vida útil.

PEREIRA FILHO, J. C. C. (2016) A nova lei do desmonte e seus reflexos jurídicos e econômicos (Lei Federal $\mathrm{n}^{\mathrm{o}}$ 12.977/2014). Disponível em: $<$ http://cpfadvogados.jusbrasil.com.br/artigos/232616933/a-nova-lei-do-desmonte-e-seusreflexos-juridicos-e-economicos>. Acesso em: 20 de junho de 2016.

RAMAlHO, A. H. P. (2006) Diagnóstico do Sistema de Gestão dos Resíduos Sólidos do Hospital de Clínicas de Porto Alegre. Dissertação de mestrado. Novo Hamburgo: Mestrado Gestão Tecnológica: Qualidade Ambiental. Porto Alegre: FEEVALE.

REZENDE, F. P. (2012) Contribuição ao estudo para implantação do centro de reciclagem de veículos pesados (caminhões). Departamento de Engenharia Civil, Universidade de Brasília, Brasília-DF.

RIO GRANDE DO SUL. Decreto n. 51.990, de 11 de novembro de 2014. Regulamenta o art. 5. ${ }^{\circ}$-A da Lei n. ${ }^{\circ} 12.745$, de 11 de julho de 2007, que dispõe sobre a comercialização de partes, peças e acessórios automotivos oriundos de veículo sinistrado ou qualquer outro veículo automotor adquirido com o fim de desmanche, na forma que especifica.

RIO GRANDE DO SUL. Lei n. 12.745, de 11 de julho de 2007. Dispõe sobre a comercialização de partes, peças e acessórios automotivos oriundos de veículo sinistrado ou qualquer outro veículo automotor adquirido com o fim de desmanche, na forma que especifica.

ROGERS, D. S.; TIBBEN-LEMBKE, R. S. (1999) Going backawards: reverse logistics trends and practices. Reverse Logistics Executive Council, Pittsburg.

SÃO PAULO. Decreto n. 60.150, de 13 de fevereiro de 2014. Regulamenta a Lei ${ }^{\circ}$ 15.276, de 2 de janeiro de 2014, que dispõe sobre a destinação de veículos em fim de vida útil

SÃO PAULO. Lei n. 15.276, de 2 de janeiro de 2014. Dispõe sobre a destinação de veículos em fím de vida útil e dá outras providências 
SCHMID, A.; NAQUIN, P.; GOURDON, R. (2013) Incidence of the level of deconstruction on material reuse, recycling and recovery from end-of life vehicles: An industrial-scale experimental study. Resources, Conservation and Recycling, v. 72, n. 2013, p. 118-126.

SHI, X. et al. (2012) Information flow in reverse logistics: and industrial information integration study. Inf Technol Manag 13, 217 - 232.

SIMIC, V.; DIMITRIJEVIC, B. (2012) Modelling production processes in a vehicle recycling plant. Waste management \& research : the journal of the International Solid Wastes and Public Cleansing Association, ISWA, v. 30, n. 9, p. 940-8.

SLACK, N.; CHAMBERS, S.; JOHNSTON, R. (2009) Administração da produção. 3 ed. São Paulo: Atlas.

SOHN, Y. T.; PARK, M. W. (2014) Development of an Adaptive Layout Design System for ELV (End-of-Life Vehicle) Dismantling Plant. Applied Mechanics and Materials, v. 510, p. 133-138.

STERMAN, J. (2000) Business dynamics: systems thinking and modeling for a complex world. Irwin McGraw-Hill.

TADEU, F. B.; PEREIRA, A. L.; BOECHAT, C. B.; SILVA, J. T. M; CAMPOS, P. M. S. (2014) Logística reversa e sustentabilidade. São Paulo: Cengage Learning.

TASALA GRADIN, K.; LUTTROPP, C.; BJÖRKLUND, A. (2013) Investigating improved vehicle dismantling and fragmentation technology. Journal of Cleaner Production, v. 54, p. 23-29.

TIAN, J.; CHEN, M. (2016) Assessing the economics of processing end-of-life vehicles through manual dismantling. Waste Management, v. 56, p. 1-12.

TIBBEN-LEMBKE, R. S. (2002) Life after death - reverse logistics and the product life cycle. Internacional Journal of Physical Distribution \& Logistics Management, v.32, n. 3.

VALLE, R.; DE SOUZA, R. G. (2014) Logística reversa: processo a processo. São Paulo: Atlas.

XU, Z. (2008) Study on information sharing platform of e-waste take-back based on EPC. J China Bus Market 2:42-45.

YI, H. C.; PARK, J. W. (2015) Design and implementation of an End-of-Life vehicle recycling center based on IoT (Internet of Things) in Korea. Procedia CIRP, v. 29, p. $728-733$.

YIN, R.K. (2010) Estudo de caso: planejamento e métodos. Bookman, Porto Alegre.

YUAN, Q; CHENG, G. (2009) An empirical study of the influence of level of application of information technology to the reverse logistics performance. Oper Manage 21:98-120.

ZHAO, Q.; CHEN, M. (2011) A comparison of ELV recycling system in China and Japan and China's strategies. Resources, Conservation and Recycling, v. 57, p. 15-21. 


\section{APÊNDICE A: QUESTIONÁRIO DA PESQUISA DE CAMPO}

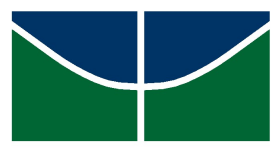

UnB - Universidade de Brasília

ENC - Departamento de Engenharia Civil

PPGT - Programa de Pós Graduação em Transporte

\section{QUESTIONÁRIO DA PESQUISA DE CAMPO EM EMPRESAS DE DESMONTAGEM}

\begin{tabular}{|c|c|}
\hline 1. Infraestrutura & $\begin{array}{l}\text { - Qual o espaço disponível? } \\
\text { - Qual a condição do espaço disponível? }\end{array}$ \\
\hline 2. Equipamentos & $\begin{array}{l}\text { - Quais os tipos de equipamentos? } \\
\text { - Qual a condição dos equipamentos? }\end{array}$ \\
\hline 3. Pessoas & $\begin{array}{l}\text { - Quantas pessoas envolvidas? } \\
\text { - Quais as funções dessas pessoas? } \\
\text { - Qual a formação dessas pessoas? }\end{array}$ \\
\hline 4. Processo & $\begin{array}{l}\text { - Quais as atividades realizadas (desmontagem e comercialização)? } \\
\text { - Qual o tempo para execução das atividades? } \\
\text { - Há registro das atividades realizadas? }\end{array}$ \\
\hline 5. Fornecedores & $\begin{array}{l}\text { - Quem são os principais fornecedores? } \\
\text { - Quais os principais insumos? }\end{array}$ \\
\hline 6. Consumidores & $\begin{array}{l}\text { - Quais os principais consumidores? } \\
\text { - Quais os principais produtos comprados? } \\
\text { - Qual a faixa de valor dos produtos? } \\
\text { - Ocorre de o consumidor precisar devolver/ trocar o produto comprado? }\end{array}$ \\
\hline 7. Resultados & $\begin{array}{l}\text { - Quantos veículos são desmontados por mês? } \\
\text { - Qual o faturamento mensal da empresa? }\end{array}$ \\
\hline 8. Relacionamento & $\begin{array}{l}\text { - Como é o relacionamento com as outras empresas? } \\
\text { - Como é o relacionamento com os órgãos reguladores e fiscalizadores? }\end{array}$ \\
\hline
\end{tabular}


APÊNDICE B: DIVISÃO DE TAREFAS PELAS PESSOAS

\begin{tabular}{|c|c|c|c|}
\hline$\#$ & Atividade & Tarefa & Responsável \\
\hline 1 & Aquisição & $\begin{array}{l}\text { Registro do centro de reaproveitamento } \\
\text { no DETRAN-DF }\end{array}$ & ADMINISTRATIVO \\
\hline 2 & Aquisição & $\begin{array}{l}\text { Levantamento dos instrumentos de } \\
\text { divulgação de leilão e venda de veículo }\end{array}$ & COMERCIAL \\
\hline 3 & Aquisição & $\begin{array}{lcc}\begin{array}{l}\text { Identificação } \\
\text { atualização } \\
\text { levantados }\end{array} & \begin{array}{c}\text { da } \\
\text { dos }\end{array} & \begin{array}{r}\text { frequência } \\
\text { instrumentos }\end{array} \\
\end{array}$ & COMERCIAL \\
\hline 4 & Aquisição & $\begin{array}{l}\text { Análise técnica das condições do } \\
\text { veículo }\end{array}$ & TÉCNICO \\
\hline 5 & Aquisição & Análise da documentação do veículo & ADMINISTRATIVO \\
\hline 6 & Aquisição & $\begin{array}{l}\text { Avaliação da } \begin{array}{c}\text { Lista de } \\
\text { Possivelmente }\end{array} \text { Reutilizáveis } \\
\text { relação às peças disponíveis, ao giro de } \\
\text { estoque e às vendas }\end{array}$ & COMERCIAL \\
\hline 7 & Aquisição & Aquisição do veículo & COMERCIAL \\
\hline 8 & Aquisição & $\begin{array}{l}\text { Acompanhamento do transporte do } \\
\text { veículo adquirido até o centro de } \\
\text { reaproveitamento }\end{array}$ & COMERCIAL \\
\hline 9 & Recebimento & $\begin{array}{l}\text { Verificação do veículo recebido e da } \\
\text { sua documentação em relação à } \\
\text { aquisição feita }\end{array}$ & TÉCNICO/ ADMINISTRATIVO \\
\hline 10 & Recebimento & $\begin{array}{l}\text { Movimentação do veículo para estoque } \\
\text { de veículos }\end{array}$ & OPERAÇÃO \\
\hline 11 & Recebimento & $\begin{array}{l}\text { Emissão de nota fiscal de entrada do } \\
\text { veículo }\end{array}$ & ADMINISTRATIVO \\
\hline 12 & Recebimento & $\begin{array}{l}\text { Vinculação do veículo a uma cartela de } \\
\text { etiquetas de rastreabilidade }\end{array}$ & ADMINISTRATIVO \\
\hline 13 & Recebimento & $\begin{array}{l}\text { Inclusão das informações iniciais do } \\
\text { veículo no sistema de informação }\end{array}$ & ADMINISTRATIVO \\
\hline 14 & Recebimento & $\begin{array}{l}\text { Solicitação do Certificado de Baixa de } \\
\text { Veículo para o órgão executivo de } \\
\text { trânsito }\end{array}$ & ADMINISTRATIVO \\
\hline 15 & Liberação & $\begin{array}{l}\text { Elaboração de Plano de Despoluição e } \\
\text { Desmontagem específico para o } \\
\text { veículo }\end{array}$ & TÉCNICO \\
\hline 16 & Liberação & $\begin{array}{l}\text { Obtenção do Certificado de Baixa de } \\
\text { Veículo no órgão executivo de trânsito }\end{array}$ & ADMINISTRATIVO \\
\hline 17 & Liberação & $\begin{array}{l}\text { Atualização do registro do veículo no } \\
\text { sistema de informação }\end{array}$ & ADMINISTRATIVO \\
\hline 18 & Despoluição & $\begin{array}{l}\text { Movimentação do veículo para área de } \\
\text { despoluição }\end{array}$ & OPERAÇÃO \\
\hline 19 & Despoluição & $\begin{array}{l}\text { Lavagem da parte externa do veículo e } \\
\text { da parte interna do capô }\end{array}$ & OPERAÇÃO \\
\hline 20 & Despoluição & $\begin{array}{l}\text { Remoção dos materiais indicados na } \\
\text { lista proposta por Cruz-Rivera (2008) }\end{array}$ & OPERAÇÃO \\
\hline 21 & Despoluição & $\begin{array}{l}\text { Remoção das rodas e dos pneus do } \\
\text { veículo para impedimento da } \\
\text { circulação em até } 10 \text { dias }\end{array}$ & OPERAÇÃO \\
\hline 22 & Despoluição & $\begin{array}{l}\text { Movimentação do veículo para área de } \\
\text { estoque de veículos, se necessário }\end{array}$ & OPERAÇÃO \\
\hline 23 & Despoluição & $\begin{array}{l}\text { Atualização do registro do veículo no } \\
\text { sistema de informação }\end{array}$ & OPERAÇÃO \\
\hline 24 & Desmontagem & $\begin{array}{l}\text { Movimentação do veículo para área de } \\
\text { desmontagem }\end{array}$ & OPERAÇÃO \\
\hline 25 & Desmontagem & $\begin{array}{l}\text { Desmontagem das peças externas } \\
\text { relacionadas à carroceria do veículo }\end{array}$ & OPERAÇÃO \\
\hline 26 & Desmontagem & Remoção dos itens de tapeçaria do & OPERAÇÃO \\
\hline
\end{tabular}




\begin{tabular}{|c|c|c|c|}
\hline & & veículo & \\
\hline 27 & Desmontagem & Remoção dos vidros do veículo & OPERAÇÃO \\
\hline 28 & Desmontagem & $\begin{array}{l}\text { Remoção dos componentes mecânicos } \\
\text { do veículo }\end{array}$ & OPERAÇÃO \\
\hline 29 & Desmontagem & $\begin{array}{l}\text { Remoção dos demais itens de } \\
\text { segurança do veículo }\end{array}$ & OPERAÇÃO \\
\hline 30 & Desmontagem & $\begin{array}{l}\text { Remoção dos componentes elétricos e } \\
\text { eletrônicos }\end{array}$ & OPERAÇÃO \\
\hline 31 & Desmontagem & $\begin{array}{l}\text { Recorte do monobloco ou chassi } \\
\text { carroceria }\end{array}$ & OPERAÇÃO \\
\hline 32 & Desmontagem & $\begin{array}{l}\text { Atualização do registro do veículo no } \\
\text { sistema de informação }\end{array}$ & OPERAÇÃO \\
\hline 33 & $\begin{array}{l}\text { Análise da } \\
\text { Qualidade }\end{array}$ & $\begin{array}{l}\text { Definição dos requisitos de qualidade } \\
\text { para reutilização, das verificações } \\
\text { capazes de atestá-los e os níveis de } \\
\text { aceitação de cada uma das peças }\end{array}$ & TÉCNICO \\
\hline 34 & $\begin{array}{l}\text { Análise da } \\
\text { Qualidade }\end{array}$ & $\begin{array}{l}\text { Movimentação das peças já } \\
\text { desmontadas para a área de análise da } \\
\text { qualidade }\end{array}$ & OPERAÇÃO \\
\hline 35 & $\begin{array}{l}\text { Análise da } \\
\text { Qualidade }\end{array}$ & $\begin{array}{l}\text { Realização dos testes de verificação da } \\
\text { qualidade com as peças movimentadas }\end{array}$ & OPERAÇÃO \\
\hline 36 & $\begin{array}{l}\text { Análise da } \\
\text { Qualidade }\end{array}$ & $\begin{array}{l}\text { Classificação das peças em: } \\
\text { reutilizáveis, passíveis de reutilização, } \\
\text { não reutilizáveis }\end{array}$ & TÉCNICO \\
\hline 37 & $\begin{array}{l}\text { Análise da } \\
\text { Qualidade }\end{array}$ & $\begin{array}{l}\text { Precificação das peças reutilizáveis de } \\
\text { acordo com critérios de precificação } \\
\text { estabelecidos }\end{array}$ & COMERCIAL \\
\hline 38 & $\begin{array}{ll}\text { Análise } & \text { da } \\
\text { Qualidade } & \end{array}$ & $\begin{array}{l}\text { Etiquetagem das peças reutilizáveis e } \\
\text { não reutilizáveis }\end{array}$ & OPERAÇÃO \\
\hline 39 & $\begin{array}{l}\text { Análise da } \\
\text { Qualidade }\end{array}$ & $\begin{array}{l}\text { Definição da estratégia de } \\
\text { gerenciamento a ser tomada para peças } \\
\text { reutilizáveis e não reutilizáveis }\end{array}$ & TÉCNICO \\
\hline 40 & $\begin{array}{l}\text { Análise da } \\
\text { Qualidade }\end{array}$ & $\begin{array}{l}\text { Preenchimento da Ficha de Análise } \\
\text { Técnica do Veículo para peças } \\
\text { reutilizáveis e não reutilizáveis }\end{array}$ & OPERAÇÃO \\
\hline 41 & $\begin{array}{l}\text { Análise da } \\
\text { Qualidade }\end{array}$ & $\begin{array}{l}\text { Aplicação das técnicas de renovação, } \\
\text { reparação e recondicionamento nas } \\
\text { peças passíveis de reutilização }\end{array}$ & OPERAÇÃO \\
\hline 42 & $\begin{array}{l}\text { Análise da } \\
\text { Qualidade }\end{array}$ & $\begin{array}{l}\text { Realização de novos testes de } \\
\text { verificação da qualidade com as peças } \\
\text { tratadas }\end{array}$ & OPERAÇÃO \\
\hline 43 & $\begin{array}{l}\text { Análise da } \\
\text { Qualidade }\end{array}$ & $\begin{array}{l}\text { Classificação das peças tratadas em: } \\
\text { reutilizáveis e não reutilizáveis }\end{array}$ & TÉCNICO \\
\hline 44 & $\begin{array}{l}\text { Análise da } \\
\text { Qualidade }\end{array}$ & $\begin{array}{l}\text { Precificação das peças tratadas } \\
\text { classificadas como reutilizáveis }\end{array}$ & COMERCIAL \\
\hline 45 & $\begin{array}{ll}\text { Análise } & \text { da } \\
\text { Qualidade } & \\
\end{array}$ & Etiquetagem das peças tratadas & OPERAÇÃO \\
\hline 46 & $\begin{array}{l}\text { Análise da } \\
\text { Qualidade }\end{array}$ & $\begin{array}{l}\text { Definição da estratégia de } \\
\text { gerenciamento a ser tomada para peças } \\
\text { tratadas }\end{array}$ & TÉCNICO \\
\hline 47 & $\begin{array}{l}\text { Análise da } \\
\text { Qualidade }\end{array}$ & $\begin{array}{l}\text { Complementação da Ficha de Análise } \\
\text { Técnica do Veículo com peças tratadas }\end{array}$ & OPERAÇÃO \\
\hline 48 & $\begin{array}{l}\text { Análise da } \\
\text { Qualidade }\end{array}$ & $\begin{array}{l}\text { Elaboração dos Laudos Técnico e } \\
\text { Técnico Complementar }\end{array}$ & TÉCNICO \\
\hline 49 & $\begin{array}{ll}\text { Análise } & \text { da } \\
\text { Qualidade } & \end{array}$ & $\begin{array}{l}\text { Atualização do registro do veículo no } \\
\text { sistema de informação }\end{array}$ & OPERAÇÃO \\
\hline 50 & Armazenamento & $\begin{array}{l}\text { Movimentação das peças reutilizáveis } \\
\text { para os locais de armazenamento } \\
\text { adequados }\end{array}$ & OPERAÇÃO \\
\hline 51 & Armazenamento & Movimentação das peças não & OPERAÇÃO \\
\hline
\end{tabular}




\begin{tabular}{l|l|l|l}
\hline & & $\begin{array}{l}\text { reutilizáveis para os locais de } \\
\text { armazenamento adequados }\end{array}$ & \\
\hline 52 & Armazenamento & $\begin{array}{l}\text { Atualização do registro do veículo no } \\
\text { sistema de informação }\end{array}$ & OPERAÇÃO \\
\hline 53 & Saída & $\begin{array}{l}\text { Atendimento ao consumidor para peças } \\
\text { reutilizáveis }\end{array}$ & COMERCIAL \\
\hline 54 & Saída & $\begin{array}{l}\text { Fechamento do preço e das condições } \\
\text { de retirada ou entrega das peças } \\
\text { reutilizáveis ou não reutilizáveis } \\
\text { (exceção grupo 4) }\end{array}$ & COMERCIAL \\
\hline 55 & Saída & $\begin{array}{l}\text { Contratação do serviço de coleta de } \\
\text { resíduos para entrega em destinação } \\
\text { final }\end{array}$ & $\begin{array}{l}\text { Emissão da nota fiscal de saída da peça } \\
\text { comercializada ADMINISTRATIVO }\end{array}$ \\
\hline 56 & Saída & $\begin{array}{l}\text { Atualização do registro do veículo no } \\
\text { sistema de informação }\end{array}$ & ADMINISTRATIVO \\
\hline 57 & Saída & $\begin{array}{l}\text { Entrega de peças não reutilizáveis } \\
\text { (grupo 4) às empresas contratadas }\end{array}$ & COMERCIAL \\
\hline 58 & Saída & $\begin{array}{l}\text { Entrega de peças vendidas com } \\
\text { condição de retirada no centro de } \\
\text { reaproveitamento }\end{array}$ & $\begin{array}{l}\text { COMERCIAL } \\
\text { condição de entrega no local de destino }\end{array}$ \\
\hline 59 & Saída & $\begin{array}{l}\text { Envio de peças vendidas com condição } \\
\text { de entrega no local de destino }\end{array}$ & COMERCIAL \\
\hline 60 & Saída & Saída & OPERAÇAO \\
\hline
\end{tabular}




\section{ANEXO A: UNIDADES DE USO E OCUPAÇÃO DO SOLO}

O Projeto de Lei Complementar 79/ 2013 - Lei Complementar de Uso e Ocupação do Solo (LUOS) do DF -, que está em estágio de revisão na câmara legislativa, identifica onze opções de Unidades de Uso e Ocupação de Solo (UOS) nas quais o tipo de atividade dessa CNAE pode ser exercida. Elas são descritas abaixo.

- CSIIR - Comercial, prestação de serviços, institucional, industria e residencial: onde é obrigatório o uso não residencial, não se admitindo o uso residencial no térreo, e que apresenta trê subcategorias.

CSIIR 1 - localizam-se nas áreas internas dos núcleos urbanos, próximo as áreas habitacionais e possuem características de âmbito local.

CSIIR 2 - localizam-se ao longo de vias estruturantes dos núcleos urbanos, em vias de atividades, centros e subcentros.

CSIIR 3 - localizam-se nas bordas dos núcleos urbanos ou próximos a áreas industriais, ocorrem em articulação com rodovias que definem a malha rodoviária principal do DF, sendo âmbito regional.

- CSIIR NO - Comercial, prestão de serviços, institucional, industrial e residencial não obrigatório: onde são permitidos os usos comercial, prestão de serviços, institucional, industrial e uso residencial, nas categorias habitação unifamiliar, ou habitação multifamiliar em tipologia de casas ou habitação multifamiliar em tipologia apartamentos, não havendo obrigatoriedade para qualquer um dos usos, e que apresenta duas subcategorias.

CSIIR 1 NO - localizam-se em áreas internas aos núcleos urbanos próximo as áreas habitacionais e possuem característica de atendimento local, de âmbito local, onde podem ocorrer qualquer um dos usos permitidos, simultaneamente ou não.

CSIIR 2 NO - localizam-se principalmente ao longo de vias estruturantes dos núcleos urbanos, em vias de atividades, centros e subcentros, onde podem ocorrer qualquer um dos usos permitidos, simultaneamente ou não.

- CSII - Comercial, prestação de serviços, institucional e industrial: onde o uso residencial é proibido, e que apresenta três subcategorias. 
CSII 1 - localizam-se em áreas internas aos núcleos urbanos, próximos às áreas habitacionais, com características de âmbito local, onde pode ocorrer qualquer um dos usos permitidos, simultaneamente ou não.

CSII 2 - localizam-se ao longo de vias estruturantes dos núcleos urbanos, em vias de atividades, centros e subcentros, onde pode ocorrer qualquer um dos usos permitidos, simultaneamento ou não.

CSII 3 - localizam-se nas boras dos núcleos urbanos ou próximas às áreas industriais, situados em articulação com rodovias que definem a malha rodoviária principal do Distrito Federal, sendo de âmbito regional.

- CSIInd - Comercial, prestação de serviços, institucional e industrial: permite, prioritariamente, as indústrias de bens de produção ou indústrias de base; indústrias de bens de capital; e indústrias de bens de consumo, é prevista para as áreas industriais e de oficinas, onde é permitida a ocorrência de outros usos não residenciais, simultaneamente, ou não, e apresenta três subcategorias:

CSIInd 1 - localizam-se em espaços francamente acessíveis, separados das áreas habitacionais, por abrigarem atividades incômodas ao uso residencial.

CSIInd 2 - localizam-se, principalmente, nas bordas dos núcleos urbanos, em espaços francamente acessíveis, separados das áreas habitacionais, por abrigarem atividades com maior incomodidade ao uso residencial; ocorrem em articulação com rodovias que definem a malha rodoviária principal do DF.

CSIInd 3 - localizam-se em áreas segregadas dos núcleos urbanos; abrigam atividades de âmbito regional, de maior risco e incomodidade.

- CSIIndR - Comercial, prestação de serviços, institucional, industrial, residencial: prevista para as áreas industriais e de oficinas, caracterizando-se por lotes de menor porte, nos quais é admitido o uso residencial unifamiliar ou multifamiliar, em pavimentos superiores, concomitante, obrigatoriamente, à atividade econômica, não sendo admitido o uso residencial em lotes remembrados e nem o remembramento de lotes, para abrigar o uso residencial. 